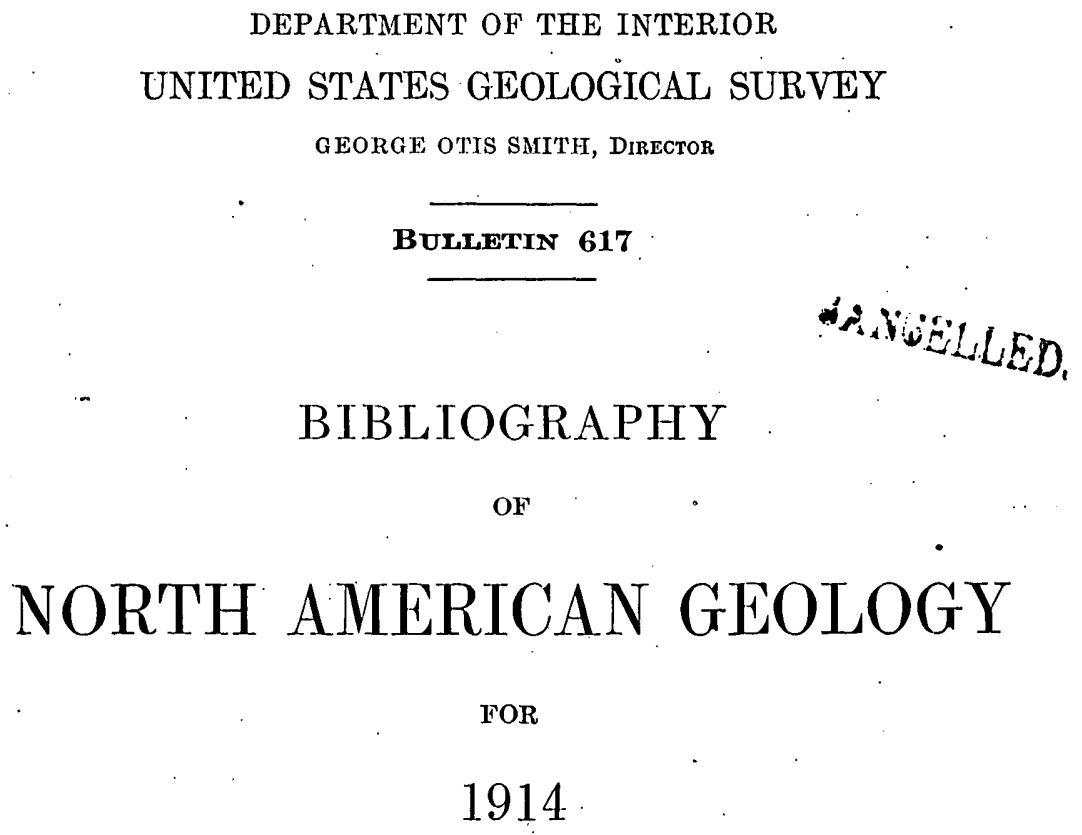

WITH SUBJECT INDEX

BY

JOHN M. NICKLES

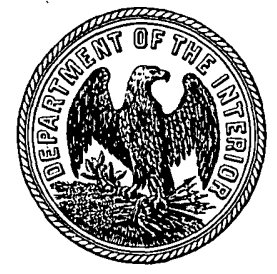

WASHINGTON

COVERNMENT PRINTING OFFICE 


\section{CONTENTS.}

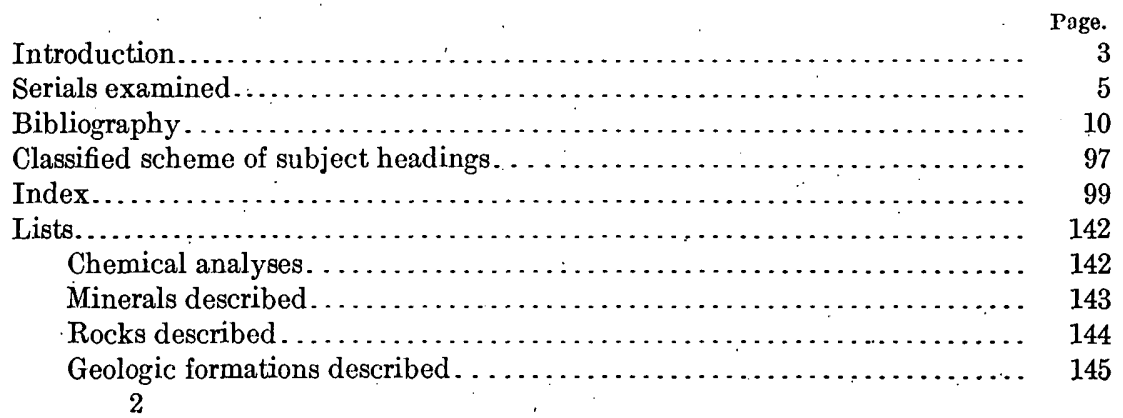




\title{
BIBLIOGRAPHY OF NORTH AMERICAN GEOLOGY FOR 1914, WITH SUBJECT INDEX.
}

\author{
By John M. NickLes.
}

\section{INTRODUCTION.}

The bibliography of North American geology, including paleontology, petrology, and mineralogy, for the year 1914 follows the plan and arrangement of its immediate predecessors, the bibliographies for 1906-7, 1908, 1909, 1910, 1911, 1912, and 1913 (Bulletins 372, $409,444,495,524,545$, and 584 of the U. S. Geological Survey). It includes publications bearing on the geology of the Continent of North America and adjoining islands; also Panama and the Hawaiian Islands. Papers by American writers on the geology of other parts of the world are not included. Textbooks and papers general in character by American authors are included; those by foreign authors are excluded unless they appear in American publications.

As heretofore, the papers, with full title and medium of publication and explanatory note when the title is not fully self-explanatory, are listed under the authors, arranged in alphabetic order. The author list is followed by an index to the literature listed. In this index the entries in one alphabet are of three kinds-first, subject, with various subdivisions, to enable the specialist to ascertain readily all the papers bearing on a particular subject or area; second, titles of papers, many of them abbreviated or inverted, under their leading words; and third, cross references, which have been freely used to avoid too much repetition. The subjects have been printed in black-faced type, the titles of papers and cross references in ordinary type. As it may not be always obvious which subject headings have been adopted, a classified scheme of those used immediately precedes the index.

Miss Isabel P. Evans has given efficient assistance in the work.

The bibliography of North American geology is comprised in the following bulletins of the United States Geological Survey: No. 127 (1732-1892); Nos. 188 and 189 (1892-1900); No. 301 (1901-1905); No. 372 (1906-7); No. 409 (1908); No. 444 (1909); No. 495 (1910); No. 524 (1911); No. 545 (1912); No. 584 (1913); and No. 617 (1914). 



\section{SERIALS EXAMINED.}

Academy of Natural Sciences of Philadelphia: Proceedings, vol. 63, pt. 3; vol. 66, pts. 1, 2. Philadelphia, Pa.

Academy of Science of St. Louis: Transactions, vol. 22, nos. 5, 6; vol. 23, nos. 1, 2. St. Louis, Mo.

Alabama Geological Survey: Bulletin, no. 14. Montgomery, Ala.

American Academy of Arts and Sciences: Proceedings, vol. 49, nos. 11, 12; vol. 50, nos. 1-6. Boston, Mass.

American Geographical Society: Bulletin, vol. 46. New York.

American Institute of Mining Engineers: Bulletin, nos. 85-96; Transactions, vols. 45, 46, 47. New York.

American Journal of Science, 4th ser., vols. 37, 38. New Haven, Conn.

American Mining Congress: 16th Ann. Session; Report of Proceedings. Denver, Colo.

American Museum of Natural History: Bulletin, vol. 33; Journal, vol. 14. New York. American Naturalist, vol. 48. New York.

American Philosophical Society: Proceedings, vol. 53, nos. 213-215. Philadelphia, $\mathrm{Pa}$.

Annales de Paléontologie, t. 9, fas. 1, 2. Paris, France.

Annales des Mines, $11^{\circ}$ sér., t. 5, 1. 1-4. Paris, France.

Annals and Magazine of Natural History, 8th ser., vols. 13, 14. London.

Appalachia, vol. 13, no. 2. Boston, Mass.

Association of Engineering Societies: Journal, vols. 52, 53. Boston, Mass.

Beiträge zur Geophysik, Bd. 13, H. 3-4. Leipzig, Germany.

Bernice Pauahi Bishop Museum: Occasional Papers, vol. 5, no. 5; vol. 6, no. 1. Honolulu, Hawaiian Islands.

Boston Society of Natural History: Proceedings, vol. 35, no. 1. Boston, Mass. .

Botanical Gazette, vols. 57, 58. Chicago, Ill.

British Columbia, Bureau of Mines: Bulletin, no. 1; Annual Report of the Minister of Mines for 1913. Victoria, B. C.

Buffälo Society of Natural Science: Bulletin, vol. 11, no. 1. Buffalo, N. Y.

Bulletins of American Paleontology, no. 24. Ithaca, N. Y.

California Academy of Sciences: Proceedings, 4th ser., vol. 2, pp. 203-274; vol. 4, pp. 15-160. San Francisco, Cal.

California State Mining Bureau: Bulletin, nos. 65, 66, 67. 'San Francisco, Cal.

California, Uniyersity of, Department of Geology: Bulletin, vol. 7, nos. 24, 25; vol. 8, nos. 1-12, 14-19. Publications in Geography: vol. 1, nos. 3, 5, 6, 7. Seismographic Stations: Bulletin, nos. 5-8. Berkeley; Cal.

Canada, Department of Mines, Mines Branch: Summary Report for 1913; and miscellaneous publications. Ottawa, Ont.

Canada, Geological Survey: Memoirs, nos. 19, 20, 22, 25, 26, 32, 36, 38, 39-44, 47, 48, 51-55, 58, 60, 61 (2d ed.), 67. Museum Memoirs, nos. 2-8. Prospector's Handbook, no. 1. Summary Report for 1912 and for 1913. Ottawa, Ont.

Canadian Mining Institute: Bulletin, nos. 21, 23-25; Monthly Bulletin, nos. 26-32; Transactions, vol. 16. Ottawa, Ont.

Canadian Mining Journal, vol. 35. Toronto and Montreal, Canada. 
Canadian Peat Society: Journal, vol. 3. Ottawa, Ont.

Canadian Record of Science, vol. 9, no. 6. Montreal, Canada.

Carnegie Institution of Washington: Yearbook no. 12, for 1913. Washington, D. C.

Carnegie Museum: Annals, vol. 9, nos. 1-2; Memoirs, vol. 3, no. 2; vol. 6, nos. 4-6.

Pittsburgh, Pa.

Centralblatt für Mineralogie, Geologie, und Paleontologie, Jahrgang 1914, nos. 1-13. Stuttgart, Germany.

Chicago Academy of Sciences: Bulletin, vol. 3, nos. 6, 10; vol. 4, nos. 1, 2. Chicago, Ill.

Cincinnati Society of Natural History: Journal, vol. 21, no. 4. Cincinnati, Ohio.

Coal Age, vols. 5, 6. New York.

Colliery Engineer, vol. 34, nos. 6-12; vol. 35, nos. 1-5. Scranton, Pa.

Colorado College Publications: Science series, vol. 12, no. 13. Colorado Springs, Colo.

Colorado Geological Survey: Bulletin 7. Denver, Colo.

Colorado School of Mines: Magazine, vol. 4; Quarterly, vol. 8, no. 4; vol. 9, nos. 1-3. Golden, Colo.

Colorado Scientific Society: Proceedings, vol. 10, pp. 415-452; vol. 11, pp. 1-28. Denver, Colo.

Colorado, University of: Studies, vol. 10, no. 4; vol. 11, nos. 1-3. Boulder, Colo.

Connecticut Academy of Arts and Sciences: Transactions, vol. 18, pp. 209-224, 291-

345. New Haven, Conn.

Davenport Academy of Sciences: Proceedings, vol. 13, pp. 1-46. Davenport, Iowa.

Delaware County Institute of Science: Proceedings, vol. 7, no. 1. Media, Pa.

Denison University, Scientific Laboratories: Bulletin, vol. 17, pp. 247-487. Granville, Ohio.

Deutsche geologische Gesellschaft: Monatsberichte, Bd. 65, No. 8-12; Bd. 66, No. 1-3. Zeitschrift, Bd. 65, H. 4; Bd. 66, H. 1. Berlin, Germany.

Economic Geology, vol. 9. Lancaster, Pa.

Elisha Mitchell Scientific Society: Journal, vol. 29, nos. 3, 4; vol. 30, nos. 1, 2. Chapel Hill, N. C.

Engineering Association of the South: Proceedings, vol. 25. Nashville, Tenn.

Engineering and Mining Journal, vols. 97, 98. New York.

Engineering Magazine, vol. 46, nos. 4-6; vol. 47; vol. 48, nos. 1-3. New York.

Engineers' Club of Philadelphia: Proceedings, vol. 31. Philadelphia, Pa.

Engineers' Society of Western Pennsylvania: Proceedings, vol. 29, no. 10; vol. 30, nos. 1-9. Pittsburgh, Pa.

Field Museum of Hatural History: Geological series, vol. 5, no. 1. Chicago, Ill.

Florida State Geological Survey: Sixth Annual Report. Tallahassee, Fla.

Franklin Institute: Journal, vols. 177, 178. Philadelphia, Pa.

Geographic Society of Chicago: Bulletin, no. 5. Chicago, Ill.

Geographical Journal, vols. 43, 44. London.

Geographical Society of Philadelphia: Bulletin, vol. 12. Philadelphia, Pa.

Der Geologe, nos. 12, 13. Leipzig, Germany.

Geological Magazine, new ser., decade 6, vol. 1. London.

Geological Society of America: Bulletin, vol. 25. New York.

Geological Society of London: Quarterly Journal, vol. 69, pt. 4; vol. 70. London.

Geologische Rundschau, Bd. 5. Leipzig, Germany.

Geologists'. Association of London: Proceedings, vol. 25. London.

Georgia Geological Survey: Bulletin, no. 29. Atlanta, Ga.

Harvard College, Museum of Comparative Zoology: Bulletin, vol. 55, no. 3; vol. 56

(Geol. ser. vol. 10), no. 2; vol. 57, no. 3; vol. 58, nos. 2-11; Memoirs, vol. 44, no. 2; vol. 46, no. 1. Cambridge, Mass.

Illinois Academy of Science: Transactions, vols. 5, 6. Springfield, Ill.

Illinois State Geological Survey: Bulletin, nos. 21, 22, 24, 28 . Urbana, Ill. 
Illinois State Laboratory of Natural History: Bulletin, vol. 10, arts. 3-5; Monograph 1; Urbana, Ill.

Imperial Earthquake Investigation Committee: Bulletin, vol. 6, nos. 2, 3; vol. 7, no. 1, vol. 8, no. 1. Tokyo, Japan.

Indiana Academy of Science: Proceedings for 1913. Indianapolis, Ind.

Indiana, Department of Geology and Natural. Resources: 37th and 38th Annual Reports. Indianapolis, Ind.

Indiana University Studies, nos. 19, 22. Bloomington, Ind.

Institution of Mining and Metallurgy: Bulletin, nos. 1.12-124; Transactions, vol. 22. London.

Institution of Mining Engineers: Transactions, vol. 46, pts. 2-5; vol. 47; vol. 48, pts. 1-2. Newcastle upon Tyne, England.

International Geological Congress: Compte-rendu de la XII ${ }^{\circ}$ Session, Canada, 1.913.

Iowa Academy of Sciences: Proceedings, vols. 20, 21. Des Moines, Iowa.

Iowa Geological Survey: Annual Report, vols. 23, 24. Des Moines, Inwa.

Johns Hopkins University: Circular, 1914, nos. 1-10. Baltimore, Md.

Journal of Geography, vol. 12, nos. 5-10; vol. 13; nos. 1-4. Madison, Wis.

Journal of Geology, vol. 22. Chicago, Ill.

Kansas Academy of Sciences: Transactions, vols. 25, 26. Topeka, Kans.

Kansas University Geological Șrvey: Bulletin, no. 1. Lawrence, Kans.

Kansas, University of: Science Bulletin, vol. 8, nos. 1-10. Lawrence, Kans.

Kentucky Geological Survey: Bulletin, nos. 16, 19; Supplementary Report on Dix River; Fourth series, vol. 1, 2 pts. and atlas, vol. 2, pt. 1.

Lake Superior Mining Institute: Proceedings, vol. 19. Ishpeming, Mich.

Mazama, vol. 4, no. 3. Portland, Oregon.

Meddelelser om Grönland: H. 32, 2 Afd; Bd. 39, 40, 51. Copenhagen, Denmark.

Mexican Mining Journal, vol. 18. Mexico City, D. F.

Michigan Academy of Science: Fifteenth Report. Lansing, Mich.

Michigan Geological and Biological Șurvey: Publication 12 (Geological series 9); 13

(Geological series 10); 14 (Geological series 11); 15 (Geological series 12); 16

(Geological series 13); 17 (Geological series 14). Lansing, Mich.

Mining and Engineering World, vols. 40, 41. Chicago, Ill.

Mining and Metallurgical Society of America: Bulletin, vol. 7. New York.

Mining and Scientific Press, vols. 108, 109. San Francisco, Cal.

Mining Magazine, vols. 10, 11. London.

Mining Science, vols. 69, 70. Denver, Colo.

Minnesota Geological Survey: Bulletin, no. 11. Minneapolis, Minn.

Mississippi State Geological Survey: Bulletin, nos. 10, 11. Jackson, Miss.

Missouri Bureau of Geology and Mines, 2d ser., vol. 12. Jefferson City, Mo.

National Academy of Sciences: Biographical Memoirs, vol. 7; Memoirs, vol. 12, pt. 1. Washington, D. C.

National Geographic Magazine, vols. 25, 26. Washington, D. C.

Nature, vol. 92 (no. 2305)-vol. 94 (no. 2357). London.

Nautilus, vol. 27, nos. 9-12; vol. 28, nos. 1-8. Philadelphia, Pa.

Neues Jahrbuch für Mineralogie, etc., 1914, Bd. 1, 2; Beilage Band, 38, 39. Stuttgart. Germany.

New Jersey Geological Survey, Bulletin, 12, 15; Geologic map. Trenton, N. J.

New York Academy of Sciences: Annals, vol. 23, pp. 145-353; vol. 24, pp. 1-170. New York.

New York Botanical Garden: Bulletin, vol. 8, no. 30. New York.

New York Mineralogical Club: Bulletin no. 3. New York.

New York State Museum: Bulletin, nos. 168-174; Memoirs, 9, pt. 2.. Albany, N. Y. North Carolina Geological and Economic Survey: Economic Paper, nos. 16, 34, 35, 37,39 . 
North Dakota Geological Survey: Sixth Biennial Report. Grand Forks, N. Dak. Ohio Naturalist, vol. 14, nos. 3-8; vol. 15, nos. 1, 2. Columbus, Ohio.

Ohio State Academy of Science: Proceedings, vol. 6, pt. 3. Columbus, Ohio.

Oklahoma Geological Survey: Bulletin, nos. 13, 17, 18, 21, 22; Map, Cushing oil field. Norman, Okla.

Ontario Bureau of Mines: Report, vol. 22, pt. 2; vol. 23. Toronto, Ont.

Oregon Bureau of Mines and Geology: Mineral Resources of Oregon, vol. 1, nos. 1-8. Corvallis, Oreg.

.Ottawa Naturalist, vol. 27 , nos. 10-12; vol. 28, nos. 1-9. Ottawa, Ont.

Palæontographica, Bd. 51, L. 1-3; Suppl. 4, Abt. 2, L. 2, 3; Abt. 2, L. 1. Stuttgart, Germany.

Palæontologische Zeitschrift, Bd. 1, H. 2. Berlin, Germany.

Pennsylvania, Topographic and Geological Survey: Biennial Report 1913-1914; Report no. 9, 10. Harrisburg, Pa.

Popular Science Monthly, vols. 84, 85. New York.

Portland Society of Natural History: Proceedings, vol. 3, pt. 1. Portland, Maine. Quebec, Mines Branch: Report on mining operations . . 1913. Quebec, Canada.

Royal Society of Canada: Proceedings and Transactions, Third series, vols. 7, 8. Ottawa, Ont.

School of Mines Quarterly, vol. 35, nos. 2-4. New York.

Science, new ser., vols. 39,40 . New York.

Science Conspectus, vol. 4. Boston, Mass.

Scientific Society of San Antonio: Bulletin, vol. 1, no. 2. San Antonio, Texas.

Seismological Society of America: Bulletin, vol. 4. Stanford University, Cal.

Sierra Club Bulletin, vol. 9, no. 3. San Francisco, Cal.

Smithsonian Institution: Smithsonian Miscellaneous Collections, vol. 61, nos. 18, 22-25; vol. 62, no. 3; vol. 63; vol. 64; Annual Report for 1913. Washington, D. C.

Sociedad científica "Antonio Alzate": Memorias y Revista, t. 32, nos. 9-10. Mexico, D. F.

Società Geologica Italiana: Bolletino, vol. 32, fasc. 4; vol. 33, fasc. 1. Rome, Italy. Société de Géographie de Québec: Bulletin, vol. 8. Quebec; Canada.

Société géologique de Belgique: Annales, t. 40, 1.3; Bulletin, t. 39; t. 41, liv. 1. Liége, Belgium.

Société géologique de France: Bulletịn, $4^{0}$ sér., t. 12, nos. 7, 8; t. 13, nos. 1-5. Paris, France.

South Dakota Geological Survey: Bulletin, no. 6. Vermilion, S. D.

South Dakota School of Mines: Bulletin, no. 14. Rapid City, S. Dak.

Southern California Academy of Sciences: Bulletin, vol. 13, nos. 1-2. Los Angeles, Cal.

Staten Island Association of Arts and Sciences: Proceedings, vol. 4, pts. 3, 4. Staten Island, N. Y.

Tennessee Academy of Science: Transactions, vol. 1. Nashville, Tenn.

Tennessee State Geological Survey: Bulletin, 10-C, 17, 18; Resources of Tennessee, vol. 4. Nashville, Tenn.

Texas, University of: Bulletin (Scientific Series), no. 28. Austin, Texas.

Torrey Botanical Club: Bulletin, vol. 41; Memoirs, vol. 15. Lancaster, Pa.

Torreya, vol. 14. Lancaster, Pa.

Tschermaks mineralogische und petrographische Mitteilungen, N. F., Bd. 32, H. 4-5. Vienna, Austria.

U. S. Bureau of Mines: Third and Fourth Annual Reports; Bulletin, nos. 37-40, $42,54,58,60,67,68,71,76,79,82,83,85,87$; Technical Papers, 35, 39, 45, 50, $57-59,61,62,65-77,85,92,94$. Washington, D. C. 
U. S. Dept. of Agriculture: Field Operations of the Bureau of Soils, Thirteenth Report. Washington, D. C.

U. S. Geological Survey: Annual Report, 35th; Bulletins, 540, 541, 543, 546-554, 556-559, 561-564, 570-572, 574-580, 581 A-D , 583-586, 588, 590, 592, 599 ; Professional Papers 81-84, 85 D, E, 86, 90 A-H; Water-Supply Papers 306, 309, $321-332,335,336,339,340$ A-E, 344, 345 B-G, 346-350, 363, 364, 366-368; Geologic Atlas of the United States, folios 191-194; Mineral Resources of the United States for 1913, pts. 1, 2. Washington, D. C.

U. S. National Museum: Bulletin, nos. 50; pt. 6, 83-87, 89; Proceedings, vol. 46, pp. 473-681; vol. 47; vol. 48, pp. 1-58, 115-193. Washington, D. C.

Vermont Geological Survey: Report of the State Geologist for 1913-4. Burlington, Vt. Virginia Geological Survey: Administrative Report 1912-13; Bulletin no. 9. Charlottesville, Va.

Virginia, University of, Publications: Bulletin of the Philosophical Society, Scientific Series, vol. 1, nos. 19-23. Charlottesville, Va.

Wagner Free Institute of Science: Transactions, vol. 7, pt. 3. Philadelphia, Pa.

Washington Academy of Sciences: Journal, vol. 4. Washington, D. C.

Washington Geological Survey: Bulletin, nos. 4, 10, 11. Olympia, Wash.

Western Engineering, vols. 4, 5. San Francisco, Cal.

Western Society of Engineers: Journal, vol. 19. Chicago, Ill.

West Virginia Geological Survey: County Reports, Kanawha County; Preston County; Map of . . . coal, oil, etc. Morgantown, W. Va.

Wisconsin Academy of Science, Arts, and Letters: Transactions, vol. 17, pts. 1, 2. Madison, Wis.

Wisconsin Natural History Society: Bulletin, new ser., vol. 11, nos. 3; 4; vol. 12. Milwaukee, Wis.

Wyoming [Geological Survey]: Series B, Bulletin, nos, 6-8; 27 (Scientific series 9). Cheyenne, Wyo.

Wyoming Historical and Geological Saciety: Proceedings and Collections, vol. 13. Wilkes-Barre, Pa.

Zeitschrift für Gletscherkunde, Bd. 8, H. 2-5; Bd. 9, H. 1. Berlin, Germany.

Zeitschrift für Krystallographie und Mineralogie, Bd. 53, H. 4-6; Bd. 54, H. 1, 2. Leipzig, Germany.

Zeitschrift für praktische Geologie, Jahrgang 22, H. 1-7. Berlin, Germany.

Zeitschrift für Vulkanologie, Bd. 1, H. 1-3. Berlin, Germany. 


\section{BIBLIOGRAPHY.}

Adams, Frank D.

1. A graphic method of representing the chemical relations of a petrographic province: Jour. Geology, vol. 22, no. 7, pp. 689-693, 2 figs., OctoberNovember, 1914; (abstract, with discussion), Geol. Soc. America, Bull., vol. 25 , no. 1, p. 43, March 30, 1914.

Adams, L. H.

Observations on the Daubrée experiment and capillarity in relation to certain geological speculations. See Johnston and Adams, no. 623.

Alden, William C.

2. Early Pleistocene glaciation in the Rocky Mountains of Glacier National Park, Montana: Int. Geol. Cong., XII, Canada, 1913, C. R., pp. 479-484, 4 figs., map, 1914.

3. Glaciers of Glacier National Park [Montana]: U. S., Dept. of the Interior, Office of the Secretary, 48 pp., 27 figs., 2 maps, 1914.

Alfaro, Anastasio.

4. Rocas sedimentarias de Costa Rica: Costa Rica, Bol. de Fomento, año 3, no. 12, pp: 853-861, 5 figs., December, 1913.

Gives a general account of the sedimentary formations of Costa Rica.

Allan, John A.

5. Geology of Field map area, British Columbia and Alberta: Canada Geol. Survey, Mem. 55, 312 pp., map, 21 pls., 5 figs., 1914.

6. Rocky Mountain section between Banff, Alberta, and Golden, British Columbia, along the Canadian Pàcific Railway: Canada Geol. Survey, Summ. Rept., 1912, pp. 165-176, 1914.

Allen, E. T., and Crenshaw, J. L.

7. The Strkes method for the determination of pyrite and marcasite: Am. Jour. Sci., 4th ser., vol. 38, pp. 371-392, 8 figs., November, 1914.

8. Effect of temperature and acidity in the formation of marcasite $\left(\mathrm{FeS}_{2}\right)$ and wurtzite $(\mathrm{ZnS})$; a contribution to the genesis of unstable forms: Am. Jour. Sci., 4th ser., vol. 38, pp. 393-431, 5 figs., November, 1914.

Allen, R. C.

9. Mineral resources of Michigan with statistical tables of production and value of mineral products for 1912 and prior years: Michigan Geol. and Biol. Survey, Pub. 13 (Geol. ser. 10), 255 pp., 4 pls., 1913.

10. Mineral resources of Michigan with statistical tables and value of mineral products for 1913 and prior years: Michigan Geol. and Biol. Survey Pub. 16 (Geol. ser. 13), 150 pp., 1914.

11. The iron ore reserves of Michigan: Michigan Geol. and Biol. Survey, Pub. 16 (Geol. ser. 13), pp. 39-77, 1914.

12. Biennial report of the director: Michigan Geol. and Biol. Survey, Pub. 17 (Geol. ser. 14), 104 pp., map, 1914.

13. Relative to an extension of the Menominee iron range eastward from Waucedah to Escanaba, Michigan: Econ. Geology, vol. 9, no. 3, pp. 236-238; 1 pl., April , 1914. 
Allen, R. C.-Continued.

14. Correlation and structure of the pre-Cambrian formations of the Givinn iron= bearing district of Michigan: Jour. Geology, vol. 22, no. 6, pp. 560-573, 1 map, September-October, 1914.

Allen, R. C., and Barrett, L. P.

15. Evidence of the middle-upper Huronian unconformity in the quartzite hills at Little Lake, Michigan: Jour. Geology, vol. 22, no. 6, pp. 574-581, 1 fig., September-October, 1914.

Alling, Mark $\mathrm{N}$.

16. Ancient auriferous gravel channels of Sierra County, California: Am. Inst. Min. Eng., Bull., no. 91, pp. 1709-1728, 1 fig., July, 1914.

Andersen, Olaf.

The binary system $\mathrm{MgO}-\dot{\mathrm{SiO}}_{2}$. $\quad$ See Bowen and Andersen, no. 109.

Anderson, Frank M.

17. Fauna of the Oligocene(?) of Oregon (abstract, with discussion): Geol. Soc. America, Bull., vol. 25, no. 1, p. 154, March 30, 1914.

Anderson, Frank M., and Martin, Bruce.

18. Neocene record in the Temblor Basin, California, and Neocene deposits of the San Juan district, San Luis Obispo County, California: California Acad. Sci., Proc., 4th ser., vol. 4, pp. 15-112, 10 pls. (incl. maps), December 30, 1914.

Argall, Philip.

19. Hetærolite from Leadville [Colorado]: Min. Mag., vol. 10, no. 6, pp. 426-427, June, 1914.

20. Siderite and sulphides in Leadville [Colorado] ore deposits: Min. and Sci. Press, vol. 109, nos. 2 and 4, pp. 50-54, 128-134, 148, 12 figs., July; 1914.

Arnold, Ralph, and Garfias, V. R.

21. Geology and technology of the California oil fields: Am. Inst. Min. Eng., Bull. no. 87, pp. 383-467, 15 figs. (incl. map), March, 1914.

Arnold, Ralph, and Hannibal, Harold.

22. Dickerson on California Eocene: Science, new ser., vol. 39, pp. 906-908, June $19,1914$.

Ashley, George H.

23. Rhode Island anthracite: U. S. Geol. Survey, Bull. 541, pp. 155-162, map, 1914.

Atwood, Wallace Walter.

24. Early Tertiary glaciation in the San Juan region of Colorado (abstract with discussion): Geol. Soc. America, Bull., vol. 25, no. 1, pp. 31-32, March 30, 1914.

25. Over the San Juan Mountains to the Mesa Verde (abstract): Am. Geog. Soc., Bull., vol. 46, no. 6, p. 430, June, 1914.

Babcock, Earle Jay.

26, The coal and clay resources of North Dakota: North Dakota, Univ., Quart. Jour., vol. 5, no. 1, pp. 52-56, October, 1914.

Bacorn, Frederick, W:

27. An amendment to Sales's theory of ore deposition: Am. Inst. Min. Eng., Bull., no. 92, pp. 1985-1991, August, 1914.

Bailey, P. P.

28. The Moyie sills: Canadian Min. Inst., Trans., vol. 16, pp. 598-607, 1913. 
Baker, Howard B.

29. Origin of continental forms, IV and III:- Michigan Acad. Sci., 15th Rept., pp. 26-32, 107-113, 4 figs., 1913.

Balliet, Letson.

30. The geology of Tonopah, Nevada: Min. and Eng. World, vol. 40, ṇo. 18, pp. 837-841, 10 figs., May 2, 1914.

Bancroft, Howland.

31. The ore deposits of northeastern Washington: U. S. Geol. Survey, Bull. 550, 215 pp., 19 pls., 26 figs., 1914.

32. Dip chart: Am. Inst. Min. Eng., Bull., no. 91, pp. 1767-1769, 2 figs., July, 1914. Geology and ore deposits near Lake City, Colorado (abstract by A. H. Brooks). See Irving and Bancroft, no. 610 .

The Republic mining district, Washington. See Lindgren and Bancroft, no. 753 .

Bancroft, J. A.

33. Preliminary report on some copper deposits of the eastern townships [of Quebec]: Quebec, Dept. of Colonization, Mines, and Fisheries, Mines Branch, Rept. of Mining Operations, 1913, pp. 48-54, 2 figs., 1914.

Includes extracts from the "Comptes-Rendus du XIIème Congrès Géologique International, Canada, 1913," giving an account of the excursions in Quebec, and extracts from the Guide Books, issued for the International Geological Congress describing various geologic features of Quebec.

Bandmann, Charles J.

34. The geology of the Battle Mountain mining district, Nevada: Min. and Eng. World, vol. 40, no. 20, p. 933, May 16, 1914.

Barbour, Erwin H.

35. Mammalian fossils from Devil's Gulch [Brown County, Nebr.]: Nebraska Univ. Studies, vol. 14, no. 2, pp. 185-202, 14 pls., April, 1914.

36. A phenomenon of the Kansan drift in Nebraska: Jour. Geology, vol. 22, no. 8, pp. 807-810, 2 figs., November-December, 1914.

37. Medusina walcotti, a Carboniferous jellyfish: Am. Jour. Sci., 4th ser., vol. 38 , pp. 505-506, 1 fig., December, 1914.

38. Carboniferous eurypterids of Nebraska: Am. Jour. Sci., 4th ser., vol. 38, pp. 507-510, 2 figs., December, 1914.

Bard, D. C., and Gidel, M. H.

Mineral associations at Butte, Mont.: Am. Inst. Min. Eng., Trans., vol. 46, pp. 123-127, 1914. See no. 39 of the bibliography for 1913, U. S. Geol. Survey, Bull. 584 .

Barnett, V. H.

39. The Douglas oil and gas field, Converse County, Wyoming: U. S. Geol. Survey; Bull. 541, pp. 49-88, 2 figs., map, 1914.

40. The Moorcroft oil field, Crook County, Wyoming: U. S. Geol. Survey, Bull. 581, pp. 83-104, 1 pl., I fig. (maps), 1914.

41. Possibilities of oil in the Big Muddy dome, Converse and Natrona counties, Wyoming: U. S. Geol. Survey, Bull. 581, pp. 105-117, 1 pl. (map), 1914.

Geology of the Standing Rock and Cheyenne River Indian reservations. See Calvert, Beekly, Barnett, and Pishel, no. 193.

Barr, James A.

42. Tennessee phosphate practice: Am. Inst. Min. Eng., Bull., no. 93, pp. 23972413, 12 figs., September, 1914. 
Barrell, Joseph.

43. The strength of the earth's crust; Part I, Geologic tests of the limits of istrength: Jour. Geology, vol. 22, no. 1, pp. 28-48, 4 figs., 1914.

44. The strength of the earth's crust; II, Regional distribution of isostatic compensation: Jour. Geology, vol. 22, no. 2, pp. 145-165, 1 fig., 1914.

45. The strength of the earth's crust; III, Influence of variable rate of isostatic compensation: Jour. Geology, vol. 22, no. 3, pp. 209-236, 2 figs., AprilMay, 1914.

46. The strength of the earth's crust; IV, Heterogeneity and rigidity of the crust as measured by departures from isostasy: Jour. Geology, vol. 22, no. 4, pp. 289-314, May-June, 1914.

47. The strength of the earth's crust; V, The depth of masses producing gravity anomalies and deflection residuals: Jour. Geology, vol. 22, no. 5, pp. 441468 , no. 6, pp. 537-555, 5 figs., 1914.

48. The strength of the earth's crust; VI, Relations of isostatic movements to a sphere of weakness-the asthenosphere: Jour. Geology, vol. 22, no. 7; pp. 655-683, 2 figs., October-November, 1914; (abstract), Science, new ser., vol. 39 , p. 842, June $5,1914$.

49. The strength of the earth's crust; VII, Variation of strength with depth as shown by the nature of departures from isostasy: Jour. Geology, vol. 22, no. 8, pp. 729-741, 3 figs., November-December, 1914.

50. The Upper Devonian delta of the Appalachian geosyncline: Am. Jour. Sci., 4th ser., vol. 37, pp. 87-109, 225-253, 2 figs., January and March, 1914.

51. The status of hypotheses of polar wanderings: Science, new ser., vol. 40, pp. 333-340, September 4, 1914.

A revised geologic time-table for North America. See Schuchert and Barrell, no.. 1057.

Barrett, Edward.

52. Thirty-eighth annual report of Department of Geology and Natural Resources, Indiana. 231 pp., pls., and maps, 1914.

53. Sullivan County [Indiana] oil field: Indiana, Dept. Geology and Nat. Res., 38th Ann. Rept., pp. 9-40, 1914.

54. Glass sands of Indiana: Indiana, Dept. Geology and Nat. Res., 38th Ann. Rept., pp. 41-59, 4 figs., 1914.

Barrett, L. P.

Evidence of the middle-upper Huronian unconformity in the quartzite hills at Little Lake, Michigan. See Allen and Barrett, no. 15.

Bassler, R. S.

55. The Paleontological Society [Princeton meeting, 1913-4]: Science, nẹw ser., vol. 39 , p. 187, January $30,1914$.

56. Proceedings of the fifth annual meeting of the Paleontological Society, held at. Princeton, New Jersey, December 31, 1913, and January 1, 1914: Geol. Soc. America, Bull.; vol. 25, no. 1, pp. 127-150, March 30, 1914.

Bastin, Edson S.

57. Geology of the pitchblende ores of Colorado: U. S. Geol. Survey, Prof. Paper 90, 5 pp., 2 pls., March 17, 1914; (abstract), Washington Acad. Sci., Jour., vol. 4, no. 10, pp. 256-257, May 19, 1914.

58. Origin of the titaniferous iron ore at Caribou, Colorado (abstract): Washington Acad. Sci., Jour., vol. 4, no. 1, p. 9, Janùary 4, 1914.

59. Graphite: U. S. Geol. Survey, Mineral Resources, 1913, pt. 2, pp. 181-251, 5 figs. (incl. map), 1914. 
Bastin, Edson S., and Williams, Henry S.

60. Description of the Eastport quadrangle, Maine: U. S. Geol. Survey, Geol. Atlas U. S., Eastport folio (no. 192), 15 pp., 7 figs., 4 maps, 2 illustrations sheets, 1914.

Bateman, A. M.

61. Exploration between Lillooet and Chilko Lake, British Columbia: Canada Geol. Survey, Summ. Rept., 1912, pp. 177-187, 1 fig. (map), 1914.

62. Lillooet map area, British Columbia: Canada Geol. Survey, Summ. Rept., 1912, pp. 188-210, map, 1914.

Bauer, C. M.

63. Clay in northeastern Montana: U. S. Geol. Survey, Bull. 540, pp. 369-372, 1 pl., 1914.

64. Lignite in the vicinity of Plentywood and Scobey, Sheridan County, Montana: U. S. Geol. Survey, Bull. 541, pp. 293-315. 1 fig., 2 maps, 1914.

Bayley, W. S.

65. The pre-Cambrian sedimentary rocks in the Highlands of New Jersey: Int. Geol. Cong. XII, Canada, 1913, C. R., pp. 325-334, 2 figs (maps), 1914.

Bayley, W. S., Salisbury, R. D., and Kümmel, H. B.

66. Description of the Raritan quadrangle, New Jersey: U. S. Geol. Survey, Geol. Atlas U. S. Raritan folio (no. 191), 32 pp., 21 figs., 5 maps, section sheet, 1914; field edition, 233 pp., 21 figs., 5 maps, section sheet, 1914; (abstract), Washington Acad. Sci., Jour., vol. 4, no. 13, p. 371, July 19, 1914.

Beal, Carl H.

67. The earthquake in the Santa Cruz Mountains, California, November 8, 1914;

Seismol. Soc. America, Bull., vol. 4, no. 4, pp. 215-219, 1 fig., map, December, 1914.

Becker, Clyde M.

68. Origin of ore bodies in replacement veins of northern Gilpin [County, Colo.]: Min. Sci., vol. 69, pp. 42-43, January, 1914.

69. Historical and geological survey of the Florida Mountains [New Mexico]: Min. Sci., vol. 70, pp. 35-36, August, 1914.

70. Sulphur deposits of southwestern Texas: Min. and Sci. Press, vol. 109, no. 8, p. 296, August 22, 1914.

71. Lead and zinc deposits in the Arbuckle Mountains [Oklahoma]: Min. Sci., vol. 70, pp. 21-22, December, 1914.

Becker, George F.

72. Note on mean density of fractured rocks: Washington Acad. Sci., Jour., vol. 4, no. 15, pp. 429-431, September 19, 1914.

Beede, J. W.

73. The Neva limestone in northern Oklahoma, with remarks upon the correlation of the vertebrate fossil beds of the State: Oklahoma Geol. Survey, Bull. no. 21, 37 pp., map, 5 figs., December, 1914.

Beekly, A. L.

Geology of the Standing Rock and Cheyenne River Indian reservations. See Calvert, Beekly, Barnett, and Pishel, no. 193.

Bell, J. Mackintosh.

74. The ore deposits of Cobalt [Ontario]: Min. Mag., vol. 10, no. 2, pp. 126-132, 4 figs., February, 1914. 
Bell, Robert:

75. The Klondike gold district in the Yukon Valley, Canada: Australasian Assoc. Adv. Sci., Rept. Twelfth Meet., Brisbane, 1909, pp. 282-296, 1910.

Bell, Robert N.

76. Fifteenth annual report of the mining industry of Idaho for the year 1913, 225 pp., illus. [1914].

Bell, W. A.

77. Joggins Carboniferous section, Nova Scotia: Canada Geol. Survey, Summ. Rept., 1912, pp. 360-371, 1914.

Berckhemer, Fritz.

A problematic fossil from the Catskill formation [Delaware Water Gap, Pa.]. See Van Tuyl and Berckhemer, no. 1227.

Berkey, Charles P.

78. Origin of some of the complex structures of the ancient gneisses of New York (abstract): New York Acad. Sci., Annals, vol. 23, p. 309, April 30, 1914.

Berkey, Charles P., and Healy, John'R.

79. The geology of New York City and its relations to engineering problems (with discussion): Municipal Engineers of the City of New York, Proc. 1911, pp. 5-39, 4 pls., 1912.

Berry, Edward Wilber.

80. The Upper Cretaceous and Eocene floras of South Carolina and Georgia: U. S. Geol. Survey, Prof. Paper 84, 200 pp., 29 pls., 12 figs., 1914; (abstract), Washington Acad. Sci., Jour., vol. 4, no. 12, p. 330, June 19, 1914.

81. A Nipa palm in the North American Eocene: Am. Jour. Sci., 4th ser., vol. 37, pp. 57-60, 1 fig. (sketch map), January, 1914.

82. Fossil plants in the Panama canal zone: Science, new ser., vol. 39; p. 357, March 6, 1914.

83. Fruits of a date palm in the Tertiary deposits of eastern Texas: Am. Jour. Sci., 4th ser., vol. 37, pp. 403-406, 2 figs., May, 1914.

84. Contributions to the Mesozoic flora of the Atlantic Coastal Plain; X, Maryland: Torrey Bot. Club, Bull., vol. 41, no. 5, pp. 295-300, May, 1914.

85. Two new Tertiary species of Trapa: Torreya, vol. 14, no. 6, pp. 105-108, 5 figs., June, 1914.

86. The affinities and distribution of the lower Eocene flora of southeastern North America: Am. Philos. Soc., Proc., vol. 53, pp. 129-250, June-July, 1914.

87. The geologic and biologic results of a study of the Tertiary floras of southeastern North America (abstract): Science, new ser., vol. 39, p. 843, June 5, 1914.

88. Additions to the Pleistocene flora of the Southern States: Torreya, vol. 14, no. 9, pp. 159-162, September, 1914.

Notes on the geological history of the walnuts and hickories: Smithsonian Inst., Ann. Rept. for 1913, pp. 319-331, 4 figs., 1914.

Reprinted from Plant World, vol. 15, pp. 225-240, 1912. See no. 73 of the bibliography for 1912, U. S. Geol. Survey Bull. 545.

Bevier, G. M.

89. The present status of the copper development in the South Mountain region: Pennsylvania Topog. and Geol. Survey, Bienn. Rept. 1912-1914, pp. 55-69, 1 pl. (map), 1914.

- Beyer, S. W., and Wright, H. F.

90. The road and concrete materials of Iowa: Iowa Geol. Survey, Ann. Rept., vol. 24, pp. 33-685, 63 pls., 65 figs., 1914. 
Billingsley, Paul.

The Southern Cross mine, Georgetown, Montana: Am. Inst. Min. Eng., Trans., vol. 46, pp. 128-136, 3 figs., 1913. See no. 75 of the bibliography for 1913, U. S. Geol. Survey, Bull. 584 .

Birgie, Edward A., and Juday, Chancey.

91. The inland lakes of Wisconsin: Wisconsin Geol. Survey, Bull. no. 27, 137 pp., 29 pls. (maps), 8 figs. (sketch maps), 1914.

Blackwelder, Eliot.

82. A summary of the orogenic epochs in the geologic history of North America: Jour. Geology, vol. 22, no. 7, pp. 633-654, October-November, 1914.

93. Post-Cretaceous history of the mountains of central western Wyoming (abstract): Washington Acad. Sci., Jour., vol. 4, no. 15, pp. 445-446, September 19, 1914.

94. Origin of the Rocky Mountain phosphate deposits (abstract): Min. and Sci. Press, vol. 109, no. 26, p. 987, December 26, 1914.

Blake, William Phipps.

85. The Cahuilla Basin, and Desert of the Colorado: Carnegie Inst. Washington, Pub: no. 193 (MacDougal, The Salton Sea), pp. 1-12, 2 pls., 1914.

Blanchard, Ralph C.

96. The geology of the western Buckskin Mountains, Yuma County, Arizona. Thesis, Columbia University. 80 pp., pls. and figs., 1913. [Private publication].

Blatchley, Raymond S.

97. The structural relations of the oil fields of Crawford and Lawrence counties, Illinois: Illinois Acad Sci., Trans., vol. 5, pp. 81-87, November, 1912.

98. The oil fields of Crawford and Lawrence counties: Illinois State Geol. Survey, Bull. no. 22, 442 pp., 31 pls. (incl. maps, part in case), 1913.

99. The Plymouth oil field: Illinois State Geol. Survey, Extract from Bull. 23, pp. 5-7, 1914.

100. Oil and gas in Bond, Macoupin, and Montgomery counties, Illinois: Illinois State Geol. Survey, Bull. no. 28, 51, pp., 4 pls. (incl. maps), 1 fig., 1914.

Bliss, Eleanora F., and Jonas, Anna I.

101. Relation of the Wissahickon mica gneiss to the Shenandoah limestone and to the Octoraro mica schist, of the Doe Run-Avondale district, Coatesville quadrangle, Pennsylvania. Dissertation . . . Bryn Mawr College. 64 pp:, 5 pls. (maps and sections), February, 1914. [?Private publication.]

Böggild, O. B.

102. Ussingit, ein neues Mineral von Kangerdluarsuk [Grönland]: Zeitschr. Kryst. Min., Bd. 54, H. 2, pp. 120-126, 1 fig., 1914; Meddelelser om Grönland, Bd. 51, Afd. 1, pp. 105-110, 1 pl: 1 fig., 1914.

Bonine, C. A.

The Elliston phosphate field, Montana. See Stone and Bonine, no. 1149.

Bowen, C. F.

103. Coal discovered in a reconnaissance survey between Musselshell and Judith, Montana: U. S. Geol. Survey, Bull. 541, pp. 329-337, map, 1914.

104. The Cleveland coal field, Blaine County, Montana; U. S. Geol. Survey, Bull. 541, pp. 338-355, map, 1914.

105. The Big Sandy coal field, Chouteau County, Montana: U. S. Geol. Survey, Bull. 541, pp. 356-378, map, 1 fig., 1914. 


\section{Bowen, Norman L.}

106. A geological reconnaissance of the Fraser River Valley from Lytton to Vancouver, British Columbia: Canada Geol. Survey, Summ. Rept., 1912, pp. 108-114, 1914.

107. The ternary system; diopside-forsterite-silica: Am. Jour. Sci., 4th ser., vol. 38 pp. 207-264, 23 figs., September, 1914.

108. Crystallization of certain pyroxene-bearing artificial melts (abstract): Geol. Soc. America, Bull., vol. 25, no. 1, p. 91, March 30, 1914.

Bowen, N. L., and Andersen, Olaf.

109. The binary system $\mathrm{MgO}-\mathrm{SiO}_{2}$ : Am. Jour. Sci., 4th ser., vol. 37 , pp. 487-500, June, 1914.

Bowie, William.

110. Isostasy and the size and shape of the earth: Science, new ser., vol. 39, pp. 697-707, May 15, 1914.

111. Some geodetic evidence of isostasy (abstract): Washington Acad. Sci., Jour., vol. 4, no. 13, pp. 382-383, July 19, 1914.

Boyce, Edward.

112. Impressions of Mount Lassen [California]: Mazama, vol. 4, no. 3, pp. 60-62, 2 pls., December, 1914.

Gives notes on eruptions of July, 1914.

Boyle, A. C., jr.

113. The geology and ore deposits of the Bully Hill mining district, California: Am. Inst. Min. Eng., Bull. no. 85, pp. 57-105, 15 figs. (incl. map), January, 1914; Trans., vol. 48, pp. 67-117, 15 figs. (incl. map), 1915.

\section{Brackenbury, C.}

114. Notes on the rocks at Levack [Ont.]: Ontario, Bur. Mines, Ann. Rept., vol. 23, pt. 1, pp. 194-201, 1 fig., 1914.

Bradley, W. M.

115. Empressite, a new silver-tellurium mineral from Colorado: Am. Jour. Sci., 4th ser., vol. 38, pp. 163-1.65, August, 1914.

On solid solution in minerals. See Foote and Bradley, no. 431.

Brainerd, Arthur E.

The geology and mineralogy of Hardwick and Woodbury, Vermont. See Richardson, Brainerd, and Jones, no. 997.

\section{Branner, John C.}

116. Report of the geology of Livermore Valley [California]: pp. 203-208, 2 pls., in The future water supply of San Francisco; a report . . . by the Spring

Valley Water Company, San Francisco, California, 1912.

117. Report on the underground water conditions of the Livermore Valley and of Sunol Valley [California]: pp. 209-222, 6 pls. (map and sections) in The future water supply of San Francisco; a report . . . by the Spring Valley Water Company, San Francisco, California, 1912.

Branson, E. B.

118. The Devonian fishes of Missouri: Missouri, Univ., Bull., vol. 15, no. 31 (Science Ser., vol. 2, no. 4), pp. 59-74, 4 pls., November, 1914.

Briscoe, Rufus Janvier.

119. The two oldest trees, one dead, one living. 63 pp., illus. Riverside, Cal.

[Los Angeles, Press of Young and McAllister, inc.], 1914,

Notes on fossil trees of Arizona.

$97921^{\circ}-$ Bull. $617-15-2$ 
British Columbia, Bureau of Mines.

Annual report of the minister of mines for the year ending 31st December, 1913, being an account of mining operations for gold, coal, etc., in the Province of British Columbia. Victoria, B. C., 1914. See Robertson, no. 1008.

Brock, Reginald Walter.

120. Summary report of the Geological Survey, Department of Mines [of Canada] for the calendar year 1912 . 544 pp., 9 maps, 2 pls., 11 figs. Ottawa, 1914.

121. Summary report of the Geological Survey, Department of Mines [of Canada] for the calendar year 1913 . 417 pp., 5 maps, 4 diagrams, 6 figs. Ottawa, 1914.

Brooks, Alfred H.

122. The mineral deposits of Alaska and the Alaskan mining industry in 1913: U. S. Geol. Survey, Bull. 592, pp. 1-74, 2 pls. (maps), 1914.

123. The Chisana placer district, Alaska: U. S. Geol. Survey, Bull. 592, pp. 309320,2 pls. (sketch maps), 1914.

124. Gold, silver, and copper in Alaska in 1913: U. S. Geol. Survey, Mineral Resources, 1913, pt. 1, pp. 213-225, 1914.

125. Mountain exploration in Alaska: Alpina Americana, no. 3,22 pp. 11 pls., 2 maps, 1 fig., 1914.

Broom, Robert.

126. Some points in the structure of the diadectid skull: Am. Mus. Nat. Hist., Bull., vol. 33, pp. 109-114, 4 figs., 1914.

127. On the structure and affinities of the Multituberculata: Am. Mus. Nat. Hist., Bull., vol. 33, pp. 115-134, 2 pls., 9 figs., 1914; (abstract, with discussion), Geol. Soc. America, Bull., vol. 25, no. 1, pp. 140-141, March 30, 1914.

128. A further comparison of the South African dinocephalians with the American pelycosaurs: Am. Mus. Nat. Hist., Bull.; vol. 33, pp. 135-141, 7 figs., 1914.

129. The origin of mammals (abstract): New York Acad. Sci. Annals, vol. 23, pp. 302-306, April 30, 1914.

Brown, Amos P.

130. Notes on the geology of the Island of Antigua: Acad. Nat. Sci. Philadelphia, Proc., vol. 65, pt. 3, pp. 584-616, 3 pls., 1914.

Brown; Amos P., and Ehrenfeld, Frederick.

131. Minerals of Pennsylvania: Pennsylvania, Topog. and Geol. Survey, Rept. no. 9, 160 pp., 10 pls., maps, 1913.

Brown, Amos P., and Pilsbry, Henry A.

132. Fresh-water mollusks of the Oligocene of Antigua: Acad. Nat. Sci. Philadelphia, Proc., vol. 66, pt. 1, pp. 209-213, 1 pl., 1 fig., March, 1914.

Brown, Barnum.

133. Cretaceous-Eocene correlation in New Mexico, Wyoming, Montana, Alberta: Geol. Soc. America, Bull., vol. 25, no. 3, pp. 355-380, 2 figs., September $15,1914$.

134. Anchiceratops, a new genus of horned dinosaurs from the Edmonton Cretaceous of Alberta, with discussion of the ceratopsian crest and the brain casts of Anchiceratops and Trachodon: Am. Mus. Nat. Hist., Bull., vol. 33, pp. 539-548, 9 pls., 1 fig., 1914.

135. A complete skull of Monoclonius, from the Belly River Cretaceous of Alberta: Am. Mus. Nat. Hist., Bull., vol. 33, pp. 549-558, 3 pls., 2 figs., 1914. 
Brown, Barnum-Continued.

136. Corythosaurus casuarius, a new crested dinosaur from the Belly River Cretaceous, with provisional classification of the family Trachodontidæ: Am. Mus. Nat. Hist., Bull., vol. 33, pp. 559-565, 1 pl., 1914.

137. Leptoceratops, a new genus of Ceratopsia from the Edmonton Cretaceous of Alberta: Am. Mus. Nat. Hist., Bull., vol. 33, pp. 567-580, 1 pl., 19 figs., 1914.

Brown, Lucius $\mathrm{P}$.

138. The brown and blue phosphate deposits of south-central Tennessee (discussion): Tennessee State Geol. Survey, Resources of Tennessee, vol. 4, no. 2, pp. 83-86, April, 1914.

139. Recent developments in the Tennessee phosphate industry: Tennessee Acad. Sci., Trans., vol. 1, pp. 74-80, August 1, 1914.

Brown, Thomas Clachar.

140. The Shawangunk conglomerate and associated beds near High Falls, Ulster County, New York: Am. Jour. Sci., 4th ser., vol. 37, pp. 464-474, 2 figs. (sketch map and section), May, 1914.

141. Origin of oolites and the oolitic texture in rocks: Geol. Soc. America, Bull., vol. 25 , no. 4, pp. 745-780, 3 pls.; 2 figs., December, 1914; (abstract, with dicussion), Geol. Soc. America, Bull., vol. 25, no. 1, pp. 58-59, March 30, 1914.

Bruce, Everend L.

142. The Swastika gold area [Canada]: School of Mines Quart., vol. 35, no. 2, pp. 154-165, January, 1914.

143. Microscopic tests on opaque minerals: School of Mines Quart., vol. 35, no. 3, pp. 187-193, April, 1914.

144. Beaver Lake mining district, Saskatchewan: Canadian Min. Jour., vol. 35, .pp. 504-505, August 1, 1914.

Bryant, Harold C.

145. Teeth of a cestraciont shark from the upper Triassic of northern California: California Univ., Dept. Geology, Bull., vol. 8, no. 3, pp. 27-30, 3 figs., March 28, 1914.

146. Vertebrate fauna of the Triassic limestones at Cow Creek, Shasta County, California (abstract): Geol. Soc. America, Bull., vol. 25, no. 1, p. 155, March 30, 1914.

\section{Bryant, J. Owen.}

147. The economic geology of a portion of Edmonson and Grayson counties [Kentucky]: Kentucky Geol. Survey, 4th ser:, vol. 2, pt. 1, pp. 155-218, pl., 1914. Also as separate, 66 pp., 1 pl., 1914.

Buchan, J. S.

148. Mount Royal [Montreal, Can.] once an active volcano: Canadian Rec. Sci., vol. 9, no. 6, pp. 338-345, 2 figs., 1914.

Buddington, Arthur F.

149. Reconnaissance of the Algonkian rocks of southeast Newfoundland (abstract): Geol. Soc. America, Bull., vol. 25, no. 1, p. 40, March 30, 1914.

Burchard, Ernest Francis.

150. Preliminary report on the red iron ores of east Tennessee, northeast Alabama, and northwest Georgia: U. S. Geol. Survey, Bull. 540, pp. 279-328, 2 pls.; 2 figs., 1914.

151. A barite deposit near Wrangell, Alaska: U. S. Geol. Survey, Bull. 592, pp. 110-117, 1 fig., 1914. 
Burchard, Ernest Francis-Continued.

152. Marble resources of the Juneau, Skagway, and Sitka districts, Alaska: U. S. Geol. Survey, Bull. 592, pp. 95-107, 1 pl. (map), 1914.

153. A barite deposit near Wrangell, Alaska: Min. and Sci. Press, vol. 109, no. 10, pp. 371-374, 2 figs., September 5, 1914.

154. Cement; fluorspar and cryolite; stone: U. S. Geol. Survey, Mineral Resources, 1913, pt. 2; pp. 117-143, 3 figs., 373-381; 1 fig., 1285-1410, 3 maps, 1914.

155. Iron ore, pig iron, and steel: U. S. Geol. Survey, Mineral Resources, 1913, pt. 1, pp. 291-338, 3 figs., 1914.

Burchard, Ernest F., and Emley, Warren E.

156. The source, manufacture, and use of lime: U. S. Geol. Survey, Mineral Resources, 1913, pt. 2, pp. 1509-1593, map; 1 pl., 4 figs., 1914.

\section{Burling, Lancaster D.}

157. Early Cambrian stratigraphy in the North American Cordillera, with discussion of Albertella and related faunas: Canada Geol. Survey, Mus. Bull. no. 2, pp. 93-129, July 6, 1914.

158. Cambrian and related Ordovician Brachiopoda-a study of their inclosing sediments: Geol. Soc. America, Bull., vol. 25, no. 3, pp. 42l-434, September 15, 1914; (abstract) Geol. Soc. America, Bull., vol. 25, no. 1, p. 137, March 30, 1914.

159. Report [on field and office work]: Canada Geol. Survey, Summ. Rept., 1913, pp. 314-321, 1914.

Burroughs, Wilbur Greeley.

160. Berea sandstone in eroded Cleveland shale; Jour. Geology, vol. 22, no. 8, pp. 766-771, 1 fig., November-December, 1914.

161. The origin of coal: Colliery Engineer, vol. 34, no. 6, pp. 351-353, January, 1914.

162. [Hocking Valley coal field, Ohio]: Colliery Engineer, vol. 34, no. 7, pp. 421424, 4 figs., February, 1914.

163. The Pittsburgh coal bed: Coal Age, vol. 5, no. 11, pp. 440-442, map, March $14,1914$.

Burrows, A. G., and Hopkins, Percy E.

164. The Kirkland Lake and Swastika gold areas and Maisonville, Grenfell, and Eby townships: Ontario, Bur. Mines, Ann. Rept., vol. 23, pt. 2, pp. 1-39, 1 pl., 29 figs., 2 maps, 1914.

Burrows, J. S.

165. Geology and location of the coal fields of Pennsylvania: Coal Age, vol. 6, no. 12, pp. 459-461, 1 fig. (map), September 19, 1914.

Burwash, Edward M.

166. On some new species of marine invertebrates from the Cretaceous of Queen Charlotte Islands [British Columbia]: Roy. Soc. Canada, Proc. and Trans., 3 d ser., vol. 7 , sect. 4 , pp. 77-89, 3 pls., 1914.

167. Pleistocene vulcanism of the Coast Range of British Columbia: Jour. Geology, vol. 22, no. 3, pp. 260-267, 3 figs., April-May, 1914.

168. A review of British Columbia geology: British Columbia Acad. Sci., Papers 1910-1914, pp. 61-66, 1914.

169. The Pleistocene volcanoes of the Coast Range of British Columbia: British Columbia Acad. Sci., Papers 1910-1914, pp. 67-75, 2 figs., 1 pl. (map), 1914. 
Bush, Faris V.

170. Phelps-Dodge in the Burro Mountains [New Mexico]: Eng. and Min. Jour., vol. 98 , no. 9, pp. 375-377, 6 figs., 2 maps, August $29,1914$.

Includes notes on the local geology and the occurrence of copper ores.

Butler, B. S.

171. Notes on the Unaweep copper district, Colorado: U. S. Geol. Survey, Bull. 580, pp. 19-23, 1914.

172. Geology and ore deposits of the San Francisco and adjacent districts, Utah: Econ. Geology, vol. 9, no. 5, pp. 413-434, 1 pl. (map), 2 figs., July; no. 6, pp. 529-558, 8 figs., September, 1914.

173. Copper: U. S. Geol. Survey, Mineral Resources, 1913, pt. 1; pp. 523-581, 1914.

174. Geology and ore deposits of the San Francisco and adjacent districts, Utah (abstract): Washington Acad. Sci., Jour., vol. 4, no. 9, pp. 222-22ं3, May 4, 1914.

Butler, B. S., and Dunlop, J. P.

175. Silver, copper, lead, and zinc in the Central Statesin 1913: U. S. Geol. Survey, Mineral Resources, 1913, pt. 1, pp. 81-171, 1914.

Butler, B. S., and McCaskey, H. D.

176. Copper ores of the New London mine [Frederick County, Mdl.]: Am. Inst. Min. Eng., Bull. no. 91, pp. 1681-1688, 3 figs., July, 1914.

Buttram, Frank.

177. Volcanic dust in Oklahoma; Oklahoma Geol. Survey, Bull. no. 13, 49 pp., 8 pls., 1 fig., December, 1914.

178: The Cushing oil and gas field, Oklahoma: Oklahoma Geol. Survey, Bull. no. 18, 107 pp., 12 pls. (incl. maps), 1 fig., December, 1914.

Butts, Charles.

179. The coal resources and general geology of the Pound quadrangle in Virginia: Virginia Geol. Survey, Bull. no. 9, 61 pp., 1 fig. 3 pls. (map and sections), 1914.

180. The coal resources and general geology of the Pound quadrangle of Virginia and Kentucky: U. S. Geol. Survey Bull. 541, pp. 165-221, 1 fig. (map), 2 pls., map, 1914.

Buwalda, John P.

181. Pleistocene beds at Manix in the eastern Mohave Desert region: California, Univ., Dept. Geology, Bull., vol. 7, no. 24, pp. 443-464, 4 pls., January $22,1914$.

182. A proboscidean tooth from the Truckee beds of Western Nevada: California, Univ., Dept. Geology, Bull., vol. 8, no. 16, pp. 305-308, I fig., December $22,1914^{\circ}$.

183. Tertiary mammal beds of Stewart and Ione valleys in west central Nevada: California, Univ., Dept. Geology, Bull., vol. 8, no. 19, pp. 335-363, 5 pls., 2 maps, December 31, 1914.

Cadell, H. M.

184. The Klondike and Yukon gold field in 1913: Scottish Geog. Mag., vol. 30, no. 7, pp. 337-356, 4. pls., 1 map, 5 figs., July, 1914.

Cady, Gilbert H.

185. Geological sequence in the vicinity of La Salle [Illinois] as revealed by recent drilling: Illinois Acad. Sci., Trans., vol. 5, pp. 87-96, 3 pls., November, 1912.

Preliminary report on the general and economic geology of the Baker district of eastern Oregon. See Grant and Cady, no. 487. 
Caimes, DeLorme D.

186. The Yukon-Alaska international boundary, between Porcupine and Yukon rivers: Canada Geol. Survey, Mem. 67, 161 pp., 2 maps (in pocket), 2 figs. (maps), 16 pls., 1914.

187. Geological section along the Yukon-Alaska boundary line between Yukon and Porcupine rivers: Geol. Soc. America, Bull., vol. 25, no. 1, pp. 179-204, 1 fig. (map), 5 pls., March 30, 1914.

188. Chisana gold fields [Alaska]: Canadian Min. Inst., Bull. no. 24, pp. 33-64, 17 figs., 1 map, 1914; Min. and Eng. World, vol. 40, no. 12, pp. 559-562, map, March 21, 1914.

189. Geology of a portion of the Yukon-Alaska boundary, between Porcupine and Yukon rivers: Canada Geol. Survey, Summ. Rept., 1912, pp. 9-11, 1914.

$\therefore$ 190. Upper White River district, Yukon [Canada]: Canada Geol. Survey, Summ. Rept., 1913, pp. 12-28, 1 fig. (map), 1914.

191. The lime belt, Quadra (South Valdes) Island, British Columbia: Canada Geol. Survey, Summ. Rept., 1913, pp. 58-75, map, 1914.

Calkins, F. C., and Jones, E. L.,.jr.

192. Economic geology of the region around Mullan, Idaho, and Saltese, Montana: U. S. Geol. Survey, Bull. 540, pp. 167-211, 1 pl. (map), 1 fig., 1914.

Call, Richard Ellsworth.

Bibliographie chronologique et analytique de Mammoth Cave, Kentucky, États-Unis d'Amérique, 1815 à 1914, traduite et ordonnée par E. A. Martel. See Hovey and Call, no. 580.

Calvert, W. R.

Geology of the Bering River field and its relations to coal mining conditions. See Fisher and Calvert, no. 422.

Calvert, W. R., Beekly, A, L., Barnett, V. H., and Pishel, M. A.

193. Geology of the Standing Rock and Cheyenne River Indian reservations; North and South Dakota: U. S. Geol. Survey, Bull. 575, 49 pp., 8 pls. (incl. maps), 1 fig., 1914; (abstract), Washington Acad. Sci., Jour., vol. 4, no. 14, p. 423, August 19, 1914.

Campbell, Marius R.

194. Coking coal in Powell Mountain, Scott County, Virginia: U. S. Geol. Survey, Bull. 541, pp. 163-164; 1914.

195. Analyses of coal samples from various fields in the United States: U. S. Geol. Survey, Bull. 541, pp. 491-526, 1914.

196. Origin of the scenic features of the Glacier National Park: U. S. Dept. of the Interior, Office of the Secretary, 42 pp., 23 figs., map, 1914.

Camsell, Charles.

197. Geology and mineral deposits of the Tulameen district, British Columbia: Canada, Geol. Survey, Mem. no. 26, 188 pp., 23 pls., 2 figs., 4 maps (in pocket), 1913.

198. The geology of certain portions of Yale district, British Columbia: Canada Geol. Survey, Summ. Rept., 1912, pp. 211-220, 1914.

199. Notes on mining developments in Similkameen district, British Columbia, and on a reported occurrence of oil at Kelowna, British Columbia: Canada Geol. Survey, Summ. Rept. 1913, pp. 127-128, 1914. 


\section{Canada, Department of Mines, Mines Branch.}

200. Summary report of the Mines Branch of the Department of Mines for the calendar year ending December 31, 1913. 214 pp., 51 pls., 24 figs., map. Ottawa, 1914.

\section{Cantwell, H. J.}

201. The disseminated lead district of southeast Missouri: Eng. and Min. Jour., vol..97, no. 5, pp. 287-290, January 31, 1914.

Capps, S. R.

202. Gold lodes and placers of the Willow Creek district: U. S. Geol. Survey, Bull. 592, pp. 245-272, 1 pl. (map), 1914.

203. Some ellipsoidal lavas on Prince William Sound, Alaska (abstract): Washington Acad. Sci., Jour., vol. 4, no. 7, p. 169, April 4, 1914.

Carman, J. Ernest.

204. Notes on the Nebraskan drift of the Little Sioux Valley, in Cherokee County: Iowa Acad. Sci., Proc., vol. 20, pp. 231-235, 1 fig. (map), 1913.

205. The Wisconsin drift-plain in the region about Sioux Falls: Iowa Acad. Sci., Proc., vol. 20, pp. 237-250, 3 figs. (maps), 1913.

Case, E. C.

206. Restoration of Edaphosaurus cruciger Cope: Am. Naturalist, vol. 48, pp. 117121, 1 pl., February, 1914.

207. Evidence of climatic oscillations in the Permo-Carboniferous beds of Texas (abstract): Geol. Soc. America, Bull., vol. 25, no. 1, p. 4l, March 30, 1914.

208. The Red Beds between Wichita Falls, Texas, and Las Vegas, New Mexico, in relation to their vertebrate fauna: Jour. Geology, vol. 22, no. 3, pp. 243-259, 11 figs., April-May, 1914.

Chamberlin, Rollin T.

209. Diastrophism and the formative processes; VII, Periodicity of Paleozoic orogenic movements: Jour. Geology, vol. 22, no. 4, pp. 315-345, MayJune, 1914.

Chamberlin, Thomas C.

210. The shelf-seas of the Paleozoic and their relations to diastrophism and time divisions: Int. Geol. Cong., XII, Canada, 1913, C. R., pp. 539-553, 1914.

211. Diastrophism and the formative processes; $V$, The testimony of the deep-sea deposits: Jour. Geology, vol. 22, no. 2, pp. 131-144, 1914.

212. Diastrophism and the formative processes; VI, Foreset beds and slope deposits: Jour. Geology, vol. 22, no. 3, pp. 268-274, 1 fig., 1914.

213. Diastrophism and the formative processes; VIII, The quantitative element in circum-continental growth: Jour. Geology, vol. 22, no. 5, pp. 516-528, July-August, 1914.

214. The fundamental segmentation of the earth (abstract); Science, new ser., vol. 40, pp. 774-77.5, November 27, 1914.

Chamberlin, Thomas C., and Salisbury, Rollin D.

215. Introductory geology. 708 pp., 16 pls., 550 figs. New York, Henry Holt and Company, 1914.

Chandler, Asa C.

216. Antelopes in the fauna of Rancho La Brea (abstract): Geol. Soc. America, Bull., vol. 25, no. 1, p. 155, March 30, 1914. 
Chapin, Theodore.

217. Quaternary deposits of the Hanagita-Bremner region, Alaska: U. S. Geol. Survey, Bull. 576, pp. 27-32, 1914.

218. Lode mining near Fairbanks [Alaska]: U. S. Geol. Survey, Bull. 592, pp. 321355, 1 pl. (map), 8 figs., 1914.

219. Placer mining in the Yukon-Tanana region [Alaska]: U. S. Geol. Survey, Bull. 592, pp. 357-362, 1914.

220. Placer mining on Seward Peninsula, Alaska: U. S. Geol. Survey, Bull. 592, pp. 385-395, 1914.

221. Lode developments on Seward Peninsula, Alaska: U. S. Geol. Survey; Bull. 592, pp. 397-407, 1 pl., 1 fig. (map), 1914.

Clapp, Charles Horace.

222. The igneous rocks of Essex County, Massachusetts. Abstract of thesis, Massachusetts Institute of Technology. $12 \mathrm{pp.}$ [Boston?], 1910.

223. Geology of the Victoria and Saanich map areas, Vancouver Island, British Columbia: Canada Geol. Survey, Mem. 36, 143 pp., 18 pls., 6 figs. (incl. maps), 1913.

224. Cocal formation on Galiano, Mayne, and Saturna islands [British Columbia]: British Columbia, Minister of Mines, Ann. Rept., 1913, pp. 292-299, map and sections, 1914.

225. Geology of the Nanaimo map area [British Columbia]: Canada Geol. Survey, Mem. 51, 135 pp., 13 pls., 10 figs., maps, 1914.

226. A geological reconnaissance on Graham Island, Queen Charlotte group, British Columbia: Canada Geol. Survey, Summ. Rept., 1912, pp. 12-40, 4 figs. (incl. map), 1914.

227. Geology of portions of the Sooke and Duncan map areas, Vancouver Island, British Columbia: Canada Geol. Survey, Summ. Rept., 1912, pp. 41-54, 1914.

228. Sharp Point hot spring, Vancouver Island, British Columbia: Canada Geol. Survey, Summ. Rept., 1913, pp. 80-83, 1914.

229. The geology of the alunite and pyrophyllite rocks of Kyuquot Sound, Vancouver Island [British Columbia]: Canada Geol. Survey, Summ. Rept., 1913, pp. 109-126, 1914.

Clapp, Charles H., and Cooke, H. C.

230. Geology of a portion of the Duncan map area, Vancouver Island, British Columbia: Canada Geol. Survey, Summ. Rept., 1913, pp. 84-106, 1914.

Clapp, William F.

231. A new fọssil Vitrinella from Boston, Massachusetts: Nautilus, vol. 28, no. 4, pp. 38-40, 1 pl., August, 1914.

Clark, B. L.

232. Fauna of the Scutella breweriana zone of the upper Monterey series (abstract):

Geol. Soc. America, Bull., vol. 25, no. 1, p. 151, March 30, 1914.

233. Fauna of the San Pablo series (abstract): Geol. Soc. America, Bull., vol. 25, no. 1, pp. 152-153, March 30, 1914.

Clark; B. W.

234. The peridotite dikes of Syracuse and vicinity [New York]: New York State Mus., Bull. 171, pp. 45-56, 2 pls., 2 figs., 1914.

Clark, Frank R.

235. Coal near Thompson, Grand County, Utah: U. S. Geol. Survey, Bull. 541, pp. 453-477, 1 fig., map, 1914. 
Clark, Frank R.--Continued.

236. Coal near Wales, Sanpete County, Utah: U. S. Geol. Survey, Bull. 541, pp. 478-489, map, 1914.

Clark, John Dustin.

237. A chemical study of the enrichment of copper sulphide ores: New Mexico, Univ., Bull. no. 75 (Chemistry Series, vol. 1, no. 2), pp. 77-150, 1 pl., 1 fig., June, 1914.

The oxidation, solution, and precipitation of copper in electrolytic solutions and the dispersion and precipitation of copper sulphides from colloidal suspensions, with a geological discussion. See Tolman and Clark, no. 1176.

Clarke, Frank Wigglesworth.

238. The constitution of the natural silicates: U. S. Geol. Survey, Bull. 588, 128 pp., 1914; (abstract), Washington Acad. Sci., Jour., vol. 4, no. 21, p. 60\%, December 19, 1914.

239. Water analyses from the laboratory of the United States Geological Survey: U. S. Geol. Survey, Water-Supply Paper 364, 40 pp., 1914; (abstract), Washington Acad. Sci., Jour., vol. 4, no. 21, p. 606, December 19, 1914.

Clarke, F. W., and Steiger, George.

240. The relative abundance of several metallic elements: Washington Acad. Sci., Jour., vol. 4, no. 3, pp. 58-62, February 4, 1.914.

Clarke, F. W., and Wheeler, W. C.

241. The composition of crinoid skeletons: U. S. Geol. Survey, Prof. Paper 90, pp. 33-37, June 16, 1914; (abstract), Washington ${ }^{\circ}$ Acad. Sci., Jour., vol. 4,'no. 14, p. 41.9, August 19, 1914.

Clarke, J. M.

242. The heart of Gaspé; sketches in the Gulf of St. Lawrence. ' xiv, 292 pp., il. New York, The Macmillan Co., 1913.

243. Tenth report of the director of the State museum and science department, including the 67 th report of the State museum, the 33d report of the State geologist, and the report of the State paleontologist for 1913: New York State Mus., Bull. 173, pp. 3-141, il., 1914.

244. Early Devonic history of New York and eastern North America; Part 2: New York State Mus., Mem. 9, 250 pp., 40 pls., figs., and maps, 1909.

245. Illustrations of intraformational corrugation (abstract, with discussion): Geol. Soc. America, Bull., vol. 25, no. 1, p. 37, March 30, 1914.

246. Illustrations of the recent exposure of the Saratoga Springs (abstract): Geol. Soc. America, Bull., vol. 25, no. 1, p. 38, March 30, 1914.

247. Newton Horace Winchell: Science, new ser., vol. 40, pp. 127-130, July 24, 1914.

248. A fossil botanical garden [Greenfield, N. Y.]. Science, new ser., vol. 40, p. 884, December 18, 1914.

Cline, Justus H.

The slate deposits of the Southern States (abstract). See Grasty and Cline; no. 490.

Examples of intercision type of stream piracy in western Virginia. See Watson, Cline, and Harnsberger, no. 1265.

Cockerell, T. D. A.

249. Tertiary Mollusca from New Mexico and Wyoming: Am. Mus. Nat. Hist., Bull., vol. 33, pp. 101-107, 3 pls., 1914. 
Cockerell, T. D. A.-Continued.

250. The fossil and recent Bombyliidæ compared: Am. Mus. Nat. Hist., Bull., vol. 33, pp. 229-236, 20 figs., 1914.

251. Land shells from the Tertiary of Wyoming: Am. Mus. Nat. Hist., Bull., vol. 33, pp. 323-325, 5 figs., 1914.

252. The fossil Orthoptera of Florissant, Colorado: Entomologist, vol. 47, pp. 32-34, 1 fig., January, 1914.

253. A new fossil sawfly from Florissant, Colorado [Tenthredella toddi]; Canadian Entomologist, vol: 46, no. 1, p. 32, January, 1914.

254. Three Diptera from the Miocene of Colorado: Canadian Entomologist, vol. 46, no. 3, pp. 101-102, March, 1914.

255. Two new plants from the Tertiary rocks of the West: Torreya, vol. 14, no. 8 , pp. 135-137, 2 figs., August, 1914.

256. New and little-known insects from the Miocene of Florissant, Colorado: Jour. Geology, vol. 22, no. 7, pp. 714-724, 11 figs., October-November, 1914.

257. Some fossil fish scales: Zool. Anzeiger, Bd. 45, Nr: 4, pp. 189-192, 1.fig., December 4, 1914.

Coffey, George N.

258. Changes of drainage in Ohio: Science, new ser., vol. 40, pp. 607-609, October 23, 1914.

Cole, L. H.

259. Gypsum in Canada; its occurrence, exploitation, and technology: Canada,

- Dept. Mines, Mines Branch, 256 pp., 30 pls., 27 figs., 6 maps, 1913.

260. Saline springs of Manitoba: Canada, Dept. Mines, Mines Branch, Summ. Rept., 1913, pp. 50-53, 1914.

Coleman, A. P.

261. Classification of the Sudbury ore deposits: Canadian Min. Inst., Trans., vol. 16, pp. 283-288, 4 pls., 1 fig. (sketch map), 1913.

262. The Sudbury series and its bearing on pre-Cambrian classification: Int. Geol. Cong., XII, Canada, 1913, C. R., pp. 387-398, 1914.

263. An estimate of postglacial and interglacial time in North America: Int. Geol. Cong., XII, Canada, 1913, C. R., pp. 435-449, 4 figs., 1914.

264. The pre-Cambrian rocks north of Lake Huron with special reference to the Sudbury series: Ontario, Bur. Mines, Ann. Rept., vol. 23, pt. 1, pp. 204236, map, 18 figs., 1914.

265. Length and character of the earliest interglacial beds (abstract, with discussion): Geol. Soc. America, Bull., vol. 25, no. 1, pp. 71, 73, March 30, 1914.

Collier, Arthur J.

266. The geology and mineral resources of the John Day region: Oregon Bur. Mines and Geol., Mineral Resources of Oregon, vol. 1, no. 3, 47 pp., 2 maps, 4 figs., 4 pls:, March, 1914.

Collins, W. H.

267. A classification of the pre-Cambrian formations in the region east of Lake Superior: Int. Geol. Cong., XII, Canada, 1913, C. R., pp. 399-407, map, 1914.

268. Geology of Onaping sheet, Ontario: Canada Geol. Survey, Summ. Rept., 1912, pp. 301-314, 1 fig. (map), 1914.

269. Geology of a portion of Sudbury map area, south of Wanapitei Lake, Ontario: Canada Geol. Survey, Summ. Rept., 1913, pp'. 189-195, map, 1914.

270. The Huronian formations of Timiskaming region, Canada: Canada Geol. Survey, Mus. Bull. no. 8, 27 pp., 2 maps, 1 fig., 1 pl., December 28, 1914. 
Condit, D. Dale.

271. Oil and gas in the northern part of the Cadiz quadrangle, Ohio: U. S. Geol. Survey, Bull. 541, pp. 9-17, map, 1914.

Connor, M. F.

272. Some notes on rock analysis: Int. Geol. Cong., XII, Canada, 1913, C. R., pp. 885-890, 1914.

Cook, Charles W.

273. The brine and salt deposits of Michigan; their origin, distribution, and exploitation: Michigan Geol. and Biol. Survey, Pub. 15 (Geol. Ser. 12), 188 pp., 15 pls., 47 figs., 1914.

Cook; W. A.

274. Lowering of the ground-water table: Kansas Acad. Sci., Trans., vol. 26, pp. 84-86, 1914.

Cooke, C. W.

Correlation of the Hawthorn formation. See Vaughan and Cooke, no. 1235.

Cooke, H. C.

275. An exploration of the headwaters of the Broadback or Little Nottaway River, northwestern Quebec; Canada Geol. Survey, Summ. Rept., 1912, pp. 337-341, map, 1914.

276. Geology of the Sooke special map area, Vancouver Island, British Columbia: Canada Geol. Survey, Summ. Rept., 1913, pp. 106-108, 1914.

Geology of a portion of the Duncan map area, Vancouver Island, British Columbia. See Clapp and Cooke, no. 230.

Coste, Eugene.

277. Rock disturbances theory of petroleum emanations vs. the anticlinal or structural theory of petroleum accumulations (with discussion by Hans von Höfer): Am. Inst. Min. Eng., Bull., no. 93, pp. 2415-2431, September, 1914; Trans., vol. 48, pp. 504-520, 1915; Canadian Min. Jour., vol. 35, pp. 647-652, 1914.

Cox, G. H.

278. Lead and zinc deposits of northwestern Illinois: Illinois State Geol. Survey,

Bull. no. 21, 120 pp., 22 pls. (incl. maps in pocket), 13 figs., 1914.

Crane, W. R.

279. The coal resources of Alaska: Am. Min. Cong., Rept. 16th Ann. Sess., 1913, pp. 192-205, 1914.

280. The lignite fields of the Cook Inlet and Kachemak Bay region, Alaska: Penn State Min. Quart., vol. 1, no. 3, pp. 101-111, 5 figs., June, 1914.

Crenshaw, J. L.

The Stokes method for the determination of pyrite and marcasite. See Allen and Crenshaw, no. 7.

Effect of temperature and acidity in the formation of marcasite $\left(\mathrm{FeS}_{2}\right)$ and wurtzite $(\mathrm{ZnS})$; a contribution to the genesis of unstable forms. See Allen and Crenshaw; no. 8.

Crider, A. F.

281. Economic geology of Tell City and Owensboro quadrangles: Kentucky Geol. Survey, Fourth Series, vol. 1, pp. 263-316, 10 figs., 1913.

282. The fire clays and fire-clay industries of the Olive Hill and Ashland districts of northeastern Kentucky: Kentucky Geol. Survey, Fourth Series, vol. 1, pp. 589-711, 1 pl., 7 figs., 1913. 
Crider, A. F.-Continued.

283. Report on the geology and mineral resources of the Dawson Springs quadrangle [Kentucky]: Kentucky Geol. Survey, 4th ser., vol. 2, pt. 1, pp. 7-67, map (in pocket), 5 figs., 1914.

284. Geology and economic products of the Earlington quadrangle [Kentucky]: Kentucky Geol. Survey, 4th ser., vol. 2, pt. 1, pp. 69-153, map and sections (in pocket), 2 figs., 1914.

Crook, A. R.

285. Notes on Sangamon County [Illinois] limestones: Illinois Acad. Sci., Trans., vol. 5, pp. 115-118, November, 1912.

Crosby, William Otis.

286. Buried gorge of the Hudson River and geologic relations of Hudson syphon of the Catskill aqueduct (abstract): Geol. Soc. America, Bull., vol. 25, no. 1, pp. 89-90, March $30,1914$.

287. Physiographic relations of serpentine, with special reference to the serpentine stock of Staten Island, New York: Jour. Geology, vol. 22, no. 6, pp. 582-593, 1 fig., September-October, 1914; (abstract, with discussion), Geol. Soc. America, Bull., vol. 25, no. 1, pp. 87-88, March 30, 1914.

Cross, Whitman.

288. Dike rocks of the Apishapa quadrangle, Colorado: U. S. Geol. Survey, Prof. Paper 90, pp. 17-31, 4 pls., June 13, 1914; (abstract), Washington Acad. Sci., Jour., vol. 4, no. 14, p. 422, August 19, 1914.

289. Problems of petrogràphic classification suggested by the "Kodurite series" of India: Jour. Geology, vol. 22, no. 8, pp. 791-806, November-December, 1914.

Cross, Whitman, and Larsen, Esper S.

290. Contributions to the stratigraphy of southwestern Colorado: U. S. Geol. Survey, Prof. Paper 90, pp. 39-50, 1 pl., 2 figs., September 17, 1914.

291. The stratigraphic break below the Jurassic sandstone in southwestern Colorado (abstract): Washington Acad. Sci., Jour., vol. 4, no. 9, pp. 237-238, May 4, 1914.

Cruess, William V.

292. Comparison of the oysters of the lower and upper horizons of the Miocene of the Muir syncline (abstract): Geol. Soc. America, Bull., vol. 25, no. 1, p. 154, March 30, 1914.

Crump, Malcolm H.

293. The oolitic limestones of Warren County [Ky.]: Kentucky Geol. Survey, Fourth Series, vol 1, pp. 1037-1051, 1913.

294. Kentucky rock asphalt: Kentucky Geol. Survey, Fourth Series, vol. 1, pp. 1053-1065, 1913.

Cumings, E. R., and Galloway, J. J.

295. The stratigraphy and paleontology of the Tanner's Creek section of the Cincinnati series of Indiana: Indiana, Dept. Geology and Nat. Res., 37th Ann. Rept., pp. 353-478, 18 figs., 20 pls., 2 sections, 1 profile and map, 1913.

Cushing, H. P., and Ruedemann, R.

296. Geology of Saratoga Springs and vicinity: New York State Museum, Bull. 169, 177 pp., 20 pls., 17 figs., 3 maps, 1914.

Dahlblom, Th.

297. The angle of shear: Int. Geol. Cong., XII, Canada, 1913, C. R., pp. 773-774, 4 figs., 1914. 
Dake, C. L.

298. Stream piracy and natural bridges in the loess of southeast Missouri: Jour. Geology, vol. 22, no. 5, pp. 498-499, 1 fig., July-August, 1914.

Dale, Nelson C.

299. Mangan ese deposits of Conception and Trinity bays, N ewfoundland (abstract): Geol. Soc. America, Bull., vol. 25, no. 1, pp. 73-74, March 30, 1914.

Dale, T. Nelson.

300. The commercial marbles of western Vermont: Vermont, State Geologist, Ninth Rept., pp. 1-160, 1.8 pls. (incl. maps), 25 figs., 1914.

301. The calcite marble and dolomite of eastern Vermont: Vermont, State Geologist, Ninth Rept., pp. 224-276, 5 pls., 1914.

Dale, T. Nelson, and others.

302. Slate in the United States: U. S. Geol. Survey, Bull 586, 220 pp., 26 pls. (including maps), 18 figs., 1914.

Dall, William H.

303. Charles Abiathar White, 1826-1910: Nat. Acad. Sci., Biog. Mem., vol. 7, pp. 223-243, port., 1911.

Daly, Reginald Aldworth.

304. Igneous rocks and their origin. xxii, 563 pp., 2 pls., 205 figs. New York, McGraw-Hill Book Company, 1914.

The chemical analyses have not been included in the list on p. 142.

305. Sills and laccoliths illustrating petrogenesis: Int. Geol. Cong., XII; Canada, 1913, C. R., pp. 189-204, 1914.

306. Geology of the Selkirk and Purcell Mountains at the Canadian Pacific Railway (main line): Canada Geol. Survey, Summ. Rept., 1912, pp. 156-164, 1914.

307. Report of the department of geology and geography: Harvard Coll., Mus. Comp. Zool., Ann. Rept. 1913-1914, pp. 17-25, 1914.

Daniels, Joseph.

308. The coal fields of Pierce County [Washington]: Washington Geol. Survey, Bull. no. 10, 146 pp., 30 pls. (including maps), 23 figs., 1914.

Darton, Nelson Horatio.

309. Some features of the Quaternary deposits in the Wyoming Valley region: Wyoming Hist. and Geol. Soc., Proc., vol. 13, pp. 41-64, 1 map, 5 pls., 1914.

310. Underground water of Luna County, New Mexico: U. S. Geol. Survey, WaterSupply Paper 345, pp. 25-37, 1 pl. (map), 1914.

311. Stratigraphy of red beds of New Mexico (abstract, with discussion): Geol. Soc. America, Bull., vol. 25, no. 1, pp. 81-82, March 30, 1.914.

312. A peculiar fault in southwestern New Mexico: Washington Acad. Sci., Jour., vol. 4, no. 11, pp. 288-289, 1 fig., June 4, 1914.

313. Stratigraphy of the red beds in New Mexico (abstract): Washington Acad. Sci., Jour., vol. 4, no. 11, p. 295, June 4, 191.4.

Davenport, $R$. W.

Preliminary report on a water-power reconnaissance in south-central Alaska. See Ellsworth and Davenport, no. 390.

Davis, Charles A.

314. Origin and formation of peat: U. S. Bur. Mines, Bull 38, pp. 165-186, 1913.

315. Peat: U. S. Geol. Survey, Mineral Resources, 1913, pt. 2, pp. 383-392, 1914. 
Davis, Charles A.-Continued.

316. Some historical evidence of coastal subsidence in New England (abstract, - with discussion): Geol. Soc. America, Bull., vol. 25, no. 1, pp. 61-63, March 30, 1914:

Davis, E. F.

317. Notes on the San Bruno earthquake of January 23, 1914: Seismol. Soc. America, Bull., vol. 4, no. 1, pp. 25-28, 1 fig. (map), March, 1914.

318. The registration of earthquakes at the Berkeley station and at the Lick Observatory Station from October 1, 1912, to March 31, 1913: California, Univ., Seismogr. Stations, Bull. no. 5, pp. 97-116, January 23, 1914.

319. The registration of earthquakes at the Berkeley station and at the Lick Observatory Station from April 1 to September 30, 1913: California, Univ., - Seismographic Stations, Bull., no.. 6, pp. 117-133, April 10, 1914.

320. The registration of earthquakes at the Berkeley Station and at the Lick Observatory Station from October 1, 1913, to March 31, 1914: California, Univ., Seismographic Stations, Bull. no. 7, pp. 135-153, September 12, 1914.

321. The registration of earthquakes at the Berkeley station and at the Lick Observatory Station from April 1, 1914, to September 30, 1914: California, Univ., Seismographic Stations, Bull., no. 8, pp. 155-168, December 19, 1914.

Davis, N. B.

322. Tourmaline-bearing quartz veins: Econ. Geology, vol. 9, no. 7, p. 589, October, 1914.

Davis, William M.

323. The home study of coral reefs: Am. Geog. Soc., Bull., vol. 46, nos. 8, 9, and 10, pp. 561-577, 641-654, 721-739, 1914.

324. Sublacustrine glacial erosion in Montana (abstract): Geol. Soc. America, Bull., vol. 25, no. 1, p. 86, March 30, 1914.

Day, Arthur L.

325. Some observations of the Volcano Kilauea in action (abstract): Geol. Soc. America, Bull., vol., 25, no. 1, pp. 80-81, March 30, 1914.

Day, Arthur L., and Shepherd, E. S.

Water and volcanic activity: Smithsonian Inst., Ann. Rept. for 1913, pp. 275-305, 11 pls., 1914.

Reprinted from Geological Society of America, Bulletin, vol. 24, pp. 573-606, 1913. See no. 300 of the bibliography for 1913, U. S. Geological Survey, Bull. 584 .

Day, Arthur L., Sosman, R. B., and Hostetter, J. C.

326. The determination of mineral and rock densities at high temperatures: Am. Jour. Sci., 4th ser., vol. 37, pp. 1-39, 12 figs., January, 1914.

Day, David T.

327. Petroleum and its derivatives: Franklin Inst., Jour., vol. 177, no. 3, pp. 271286, March, 1914.

328. Platinum and allied metals: U. S. Geol. Survey, Mineral Resources, 1913, pt. 1, pp. $445-457,1914$.

329. Asphalt: U. S. Geol. Survey, Mineral Resources, 1913, pt. 2, pp. 537-544, 1914.

Oil shale of northwestern Colorado and northeastern Utah. See Woodruff and Day, no. 1333.

Bituminous shale in northwestern Colorado and northeastern Utah (abstract). See Woodruff and Day, no. 1334.

Day, David T., and others.

330. [Map of the] oil and gas fields [of the United States] in 1913: U. S. Geol. Survey, 1914. Scale, $1: 2,500,000$. 
De Beque, G. R.

331. De Beque petroleum field in Colorado: Eng. and Min. Jour., vol. 98, no. 15, pp. 652-653, 1 fig., October 10, 1914.

Decker, Charles E.

332. $\Lambda$ tufa deposit near Danville, Illinois: Illinois Acad. Sci., Trans., vol. 5, pp. 109-111, 2 figs., November, 191.2.

Denis, Theo. C.

333. Report on mining operations in the Province of Quebec during the year 1913: Quebec (Province), Dept. of Colonization, Mines, and Fisheries, Mines Branch, 163.pp., figs., 1914.

De Schmid, Hugh S.

334. Mica mining in Canada: Canadian Min. Inst., Quart. Bull., no. 21, pp. 19-41, March, 1913; Trans., vol. 16, pp. 371-393, 1913.

335. White mica occurrences in the Tete Jaune Cache and Big Bend districts of British Columbia: Canada, Dept. Mines, Mines Branch, Summ. Rept. 1913, pp. 42-49, 3 pls., 2 figs. (incl. map), 1914.

Deussen, Alexander.

336. Geology and underground waters of the southeastern part of the Texas Coastal Plain: U. S. Geol. Survey, Water-Supply Paper 335, 365 pp., 9 pls. (incl. maps in pocket), 17 figs., 1914.

DeWolf, Frank W.

337. Work of the State geological surveys: Min. and Sci. Press, vol. 108, no. 1, pp. 35-37, January $3,1914$.

Dick, W. J.

338. Conservation of coal in Canada with notes on the principal coal mines: Canada, Commission on Conservation, 212 pp., 26 pls., 2 maps, 1914.

Dickerson, Roy Ernest.

339. Note on the faunal zones of the Tejon group: California Univ., Dept. Geology, Bull., vol. 8, no. 2, pp..17-25, 1 fig., February 4, 1914.

340. Tauna of the Martinez Eocene of California: California Univ., Dept. Geology, Bull., vol. 8, no. 6, pp. 61-180, 13 pls., 5 figs. (maps and sections), May 13, 1914.

341. The Martinez and Tejon Eocene and associated formations of the Santa Ana Mountains [California]: California Univ., Dept. Geology, Bull., vol. 8, no. 11, pp. 257-270, 2 pls., 1 fig., map, December 22 , 1914.

342. The Martinez Eocene and associated formations at Rock Creek on the western border of the Mohave Desert area: California Univ., Dept. Geology, Bull., vol. 8, no. 14, pp. 289-298, 1 fig., December 10, 1914.

343. New molluscan species from the Martinez Eocene of southern California: California Univ., Dept. Geology, Bull., vol. 8, no. 15, pp. 299-304, 1 pl., December 10, 1914.

344. Minutes of the fourth annual meeting of the Pacific coast section of the Paleontological Society: Geol. Soc. America, Bull., vol. 25, no. 1, pp. 150-156, March 30, 1914.

345. Faunal zones of the Martinez Eocene of California (abstract): Geol. Soc. America, Bull., vol. 25, no. 1, p. 154, March 30, 1914.

346. The Tone formation of the Sierra Nevada foothills, a local facies of the upper Tejon-Eocene: Science, new ser., vol. 40, pp. 67-70, July 18, 1914.

347. The fauna of the Siphonalia sutterensis zone in the Roseburg quadrangle, Oregon: California Acad. Sci., Proc., 4th ser., vol. 4, pp. 113-128, 2 pls., December 30, 1914. 
Diller, J. S.

348. Auriferous gravels in the Weaverville quadrangle, California: U. S. Geol. Survey, Bull. 540, pp. 11-21, 1 pl., 2 figs. (incl. map), 1914.

349. The Lassen eruption: Science, new ser., vol. 40, pp. 49-51, July 10, 1914.

350. Mineral resources of the Southern States-distribution and production (abstract): Science, new ser., vol. 39, p. 399, March 13, 1914.

351. The eruptions of Lassen Peak, California: Seismol. Soc. America, Bull., vol. 4, no. 3, pp. 103-107, 5 pls., September, 1914; Mazama, vol. 4, no. 3, pp. 54-59, 2 pls., December, 1914.

352. Mineral resources of southwestern Oregon: U. S. Geol. Survey, Bull. 546, 147 pp., 11 pls. (incl. maps), 26 figs. (maps and sections), 1914; (abstract) Washington Acad. Sci., Jour., vol. 4, no. 12, p. 329, June 19, 1914.

353. Chromic iron ore: U. S. Geol. Survey, Mineral Resources, 1913, pt. 1, pp. 29-39, 2 figs., 1914.

354. Talc and soapstone: U. S. Geol. Survey, Mineral Resources, 1913, pt. 2, pp. 153-163, 2 figs., 1914.

355. Asbestos: U. S. Geol. Survey, Mineral Resources, 1913, pt. 2, pp. 339-354 4 figs. (incl. map), 1914.

Dobbs, W. S.

356. Geological sketch of the property of the Hayden gold mines, Ltd. [Ontario]: Min. and Sci. Press, vol. 108, no. 13, pp. 534-535, 1 fig. (map), March 28, 1914.

Dolbear, Samuel H.

357. The saline deposits of Searles Lake, California: Min. and Eng. World, vol. 41, no. 18, pp. 797-800, 8 figs., October 31, 1914.

Dole, R. B.

358: Mineral waters; radioactivity of mineral waters: U. S. Geol. Survey, Mineral Resources, .1913, pt. 2, pp. 393-440, 1914.

Douglas, James.

359. The copper-bearing traps of the Coppermine River [Canada]: Canadian Min. Inst., Trans., vol. 16, pp. 83-101, 1 map, 3 figs., 1913.

Douglass, Earl.

360. Geology of the Uinta formation: Geol. Soc. America, Bull., vol. 25, no. 3, pp. 417-420, September 15, 1914.

Dowling, D. B.

361. Coal fields of Manitoba, Saskatchewan, Alberta, and eastern British Columbia (revised edition): Canada Geol. Survey, Mem. 53, 142 pp., map (in pocket), 9 pls., 1914.

362. Geological notes to accompany map of Sheep River gas and oil.field, Alberta: Canada Geol. Survey, Mem. 52, 26 pp., 1 map (in pocket), 3 pls., 1914.

363. North Saskatchewan River coal areas, Alberta: Canada-Geol. Survey, Summ. Rept. 1913, pp. 150-152, 1914.

364. Geological notes on the Sheep River gas and oil field, Alberta: Canada Geol. Survey, Summ. Rept., 1913, pp. 142-149, 1914.

365. Coal areas in Flathead Valley, British Columbia: Canada Geol. Survey, Summ. Rept., 1913, pp. 139-141, 1 fig., 1914.

Drake, N. F.

366. Economic geology of the Waynesboro quadrangle [Tennessee]: Tennessee State Geol. Survey, The Resources of Tennessee, vol. 4, no. 3, pp. 99120,2 figs., July, 1914. 


\section{Dresser, John A.}

367. Preliminary report on the serpentine and associated rocks of southern Quebec: Canada Geol. Survey, Mem. no: 22, 103 pp., 11 pls., 7 figs., 3 maps, 1913.

368. Asbestos in southern Quebec: Am. Inst. Min. Eng., Bull., no. 93, pp. 22672274, September, 1914; Canadian Min. Jour., vol. 35, pp. 600-604, 4 figs., September 15, 1914.

Drysdale, Chas. W.

368. Geology of the Thompson River Valley below Kamloops Lake, British Columbia: Canada Geol. Survey, Summ. Rept., 1912, pp. 115-150, map, 1914.

370. Rossland mining camp, British Columbia: Canada Geol. Survey, Summ. Rept., 1913, p. 129, 1914.

\section{Dulieux, E.}

371. The iron resources of the Province of Quebec: Canadian Min. Inst., Trans., vol. 16, pp. 351-370, 2 figs., 1913.

Dumble, E. T.

372. The age and manner of formation of petroleum deposits: Am. Inst. Min. Eng., Bull. no. 87, pp. 501-512, March, 1914; Trans., vol. 48, pp. 521-532, 1915.

Dunbar, Carl 0.

Nodules with fishes from the coal measures of Kansas. See Twenhofel and Dunbar, no. 1191.

Dunlop, J. P.

Silver, copper, lead, and zinc in the Central States in 1913. See Butler and Dunlop, no. 175.

Eakin, Henry M.

373. The Iditarod-Ruby region, Alaska: U. S. Geol. Survey, Bull. 578, 45 pp., 6 pls. (1-3 in pocket), 1. fig., 1914.

374. Placer mining in the Ruby district [Alaska]: U. S. Geol. Survey, Bull. 592, pp. 363-369, 1914.

375. Mineral resources of the Yukon-Koyukuk region, Alaska: U. S. Geol. Survey, Bull. 592, pp. 371-384, 1 pl. (map), 1914.

376. The conditions of "altiplanation" in sub-Arctic regions (abstract): Washington Acad. Sci., Jour., vol. 4, no. 7, p. 171, April 4, 1914.

Eakle, Arthur S.

377. Minerals of California: California State Mining Bureau, Bull. no. 67, 226 pp., 1914.

NotE.-Minerals described not included in list of minerals described on page 143.

378. Some contact metamorphic minerals in crystalline limestone at Crestmore, near Riverside, California (abstract): Geol. Soc. America, Bull., vol. 25. no. 1, p. 125, March 30, 1914.

Eakle, Arthur S., and Rogers, Austin F.

379. Wilkeite, a new mineral of the apatite group, and okenite, its alteration product, from Southern California: Am. Jour. Sci., 4th ser., vol. 37, pp. 262267, 1 fig., March, 1914.

Earle, Raymond Bartlett.

380. The genesis of certain Paleozoic interbedded iron ore deposits: New York Acad. Sci., Annals, vol. 24, pp. 115-170, 15 pls., August 4, 1914; (abstract, with discussion), New York Acad. Sci., Annals, vol. 23, pp. 277-278, 287, April 30, 1914.

$97921^{\circ}-$ Buill. $617-15-3$ 
Eastman, C. R.

381. Notes on Triassic fishes belonging to the families Catopteridæ and Semionotidæ: Carnegie Mus., Annals, vol. 9, nos. 1-2, pp. 139-148, 3 pls., September, 1914.

Easton, H. D.

382. Report on the technology of Kentucky clays, including chemical and mechanical analyses, and burning tests: Kentucky Geol. Survey, Fourth Series, vol. 1, pp. 713-888, 1913.

Eckel, Edwin C.

383. Iron ores; their occurrence, valuation, and control. First ed., xvii, $430 \mathrm{pp}$., 66 figs. (incl. maps), New York, McGraw-Hill Book Company, 1914. See also Dale and others, no. 302.

Edwards, M. G.

384. The occurrence of aluminum hydrates in clays: Econ. Geology, vol. 9, no. 2, pp. 112-121, 2 figs., March, 1914.

Ehrenfeld; Frederick.

Minerals of Pennsylvania. See Brown and Ehrenfeld, no: 131.

Ekblaw, W. Elmer.

385. Correlation of the Devonian system of the Rock Island region [Illinois]: Illinois Acad. Sci., Trans., vol. 5, pp. 96-109, 2 figs., November, 1912.

Elkins, Marion G., and Wieland, G. R.

386. Cordaitean wood from the Indiana black shale: Am. Jour. Sci., 4th ser., vol. 38, pp. 65-78, 11 figs., 2 pls., July, 1914.

Ells, S. C.

387. Preliminary report on the bituminous sands of northern Alberta: Canada, Dept. Mines, Mines Branch, 92 pp., 55 pls., 5 figs., map (in pocket), 1914.

388. Summary report on bituminous sands of northern Alberta: Canada, Dept. Mines, Mines Branch, Summ. Rept. 1913, pp. 54-62, 9 pls., map, 1914.

Ellsworth, C. E., and Davenport, R. W.

389. Preliminary report on a water-power reconnaissance in south-central Alaska: U. S. Geol. Survey, Bull. 592, pp. 155-193, 4 pls. (maps), 1 fig. (map), 1914.

Ellsworth, W. E.

390. The Calgary; Alberta, oil fields, Canada: Min. and Eng. World, vol. 40, no. 26, pp. 1190-1194, 1234, 2 maps, 5 figs., June 27, 1914.

Emley, Warren E.

The source, manufacture, and use of lime. S'ee Burchard and Emley, no. 156 .

\section{Emmens, Newton W.}

391. On the Babine Lake section, Omineca district, British Columbia: Min. and Eng. World, vol. 41, no. 2, pp. 47-50, map, 3 figs., July 11, 1914.

Emmons, W. H.

392. The mineral composition of primary ore as a factor determining the vertical range of metals deposited by secondary processes: Int. Geol. Cong., XII, Canada, 1913, C. R., pp. 261-269, 1914.

English, Walter A.

393. The Fernando group near Newhall, California: California, Univ., Dept. Geology, Bull., vol. 8, no. 8, pp. 203-218, 1 pl., November 7, 1914. 
English, Walter A.-Continued.

394. The Agasoma-like gastropods of the California Tertiary: California, Univ., Dept. Geology, Bull., vol. 8, no. 10, pp. 243-256, 2 pls., November, $13,1914$.

395. Fauna of lower Fernando series (abstract): Geol. Soc. America, Bull., vol. 25, no. 1, p. 151, March 30, 1914.

Geology and oil prospects in Waltham, Priest, Bitterwater, and Peachtree valleys, California. See Pack and English, no. 903.

Epry, Ch.

396. Ripple marks: Smithsonian Inst., Ann. Rept. for 1913, pp. 307-318, 10 pls., 1914.

Evans, Geo. Watkin.

397. Some notes on the Groundhog anthracite coal field [British Columbia]: Canadian Min. Inst., Trans., vol. 16, pp. 434-441, 4 pls., 1913.

398. The Issaquah coal mine [Washington]: Colliery Engineer, vol. 34, no. 11, pp. 663-666, 9 figs., June, 1914.

Evans, Isabel $P$.

399. Publications by Survey authors on metals and nonmetals except fuels: U. S. Geol. Survey, Bull. 580, pp. 413-455, 1914.

Fairchild, Herman' L.

400. Pleistocene marine submergence of the Connecticut and Hudson valleys: Geol. Soc. America, Bull., vol. 25, no. 2, pp. 219-242, 2 pls., June 29, 1914; (abstract, with discussion), Geol. Soc. America, Bull., vol. 25, no. 1, pp. 63-65, March 30, 1914.

401. Review of the early history of the society: Geol. Soc. America, Bull., vol. 25, рo. 1, pp. 17-24, March 30, 1914.

Faribault, E. R.

402. Greenfield and Liverpool town map areas, Nova Scotia: Canada Geol. Survey, Summ. Rept., 1912, pp. 372-378, 1914.

403. Oldham gold district, Nova Scotia: Canada Geol. Survey, Summ. Rept., 1912, pp. 379-382, 1914.

404. Clays in Lunenburg County, Nova Scotia: Canada Geol. Survey, Summ. Rept. 1912, p. 383, 1914.

405. Geology of the Port Mouton map area, Queens County, Nova Scotia: Canada. Geol. Survey, Summ. Rept. 1913, pp. 251-258, 1914.

406. Geology of the gold district of Pleasant River Barrens, Lunenburg County, Nova Scotia: Canada Geol. Survey, Summ. Rept. 1913, pp. 259-263, map, 1914.

Farr, Clifford H.

407. Notes on a fossil tree fern of Iowa: Iowa Acad. Sci., Proc., vol. 21, pp. 59-65, 3 figs., 1914.

Farrington, Oliver Cummings.

408. Meteorites vs. the earth: Am. Jour. Sci., 4th ser., vol. 37, pp. 200-201, February, 1914.

409. New meteorites: Field Mus. Nat. Hist., Geol. Ser., vol. 5, no. 1, pp. 1-14, 6 pls., August 1, 1914.

Fay, Charles E.

410. The Canadian Rocky Mountairs; Alpina Americana, no. 2, 19 pp., 12 pls. (incl. maps), 1911. 
Fenneman, N. M.

411. Preglacial Miami and Kentucky rivers (abstract, with discussion): Geol. Soc. America, Bull., vol. 25, no. 1, p. 85, March 30, 1914.

Fenner, Clarence N.

412. Mode of formation of certain gneisses in the Highlands of New. Jersey (abstract, with discussion): Geol. Soc. America, Bull., vol. 25, no. 1, pp. 44-45, March 30; 1914.

413. The mode of formation of certain gneisses in the Highlands of New Jersey: Jour. Geology, vol. 22, no. 6, pp. 594-612, 14 figs.; no. 7, pp. 694-702, September-November, 1914.

414. Babingtonite from Passaic County, New Jersey: Washington Acad. Sci., Jour., vol. 4, no. 19, pp. 552-558, 1 fig., November 19, 1914.

415. Additional notes on babingtonite from Passaic County, New Jersey: Washington Acad. Sci., Jour., vol. 4, no. 21, pp. 598-605, December 19, 1914.

Ferguson, Henry G.

416. Gold lodes of the Weaverville quadrangle; California: U. S. Geol. Survey, Bull. 540, pp. 22-79, 1 pl:, 2 figs. (incl. map), 1914.

417. Lode deposits of the Alleghany district, California: U. S. Geol. Survey, Bull. 580, pp. 153-182, 8 figs. (incl. map), 1914.

Ferguson, J. B.

418. The occurrence of molybdenum in rocks with special reference to those of Hawaii: Am. Jour. Sci., 4th ser., vol. 37, pp. 399-402, May, 1914.

Fermor, L. Leigh.

419. On the formation in depth of oxidized ores and of secondary limestones: Int. Geol. Cong., XII, Canada, 1913, C. R., pp. 271-274, 1914.

Fettke, Charles Reinhard.

420. The Manhattan schist of southeastern New York State and its associated igneous rocks: New York Acad. Sci., Annals, vol. 23, pp: 193-260, 8 pls., 1914.

Fieldner, Arno C., and others.

421. Analyses of mine and car samples of coal collected in the fiscal years 1911 to 1913: U. S. Bur. Mines, Bull. 85, 444 pp., 2 figs., 1914.

Fisher, C: A., and Calvert, W. R.

422. Geology of the Bering River field and its relations to coal mining conditions: U. S., 63d Cong., 2d Sess., H. R. Doc. no. 876, pp. 29-50, 2 maps, Washington, 1914.

Flagg, Arthur L.

The Elk City mining district, Idaho County, Idaho: Am. 'Inst. Min. Eng., Trans., vol. 45, pp. 113-122, 1 fig. (map), 1914. See no. 372 of the bibliography for 1913, U. S. Geol. Survey, Bull. 584.

Foerste, August F.

423. Supplementary report on Dix River [Kentucky]: Kentucky Geol. Survcy, 3 pp., [1912].

424. The identification of Trenton and lower geological horizons: Kentucky Geol. Survey, Fourth Series, vol. 1, pp. 365-376, 1913.

425. A chemical study of the Trenton and Stone's River rocks in central Kentucky: Kentucky Geol. Survey, Fourth Series, vol. 1, pp. 377-386, 1913.

426. The phosphate deposits in the upper Trenton limestones of central Kentucky: Kentucky Geol. Survey, Fourth Series, vol. 1, pp. 387-439, 2 figs., map, 1913. 
Foerste, August F.-Continued.

427. The Rogers Gap fauna of central Kentucky: Cincinnati Soc. Nat. Hist., Jour., vol. 21, no. 4, pp. 109-156, 4 pls., May, 1914.

428. Notes on the Lorraine faunas of New York and the Province of Quebec: Denison Univ., Sci. Lab., Bull., vol. 17, pp. 247-339, 5 pls., March, 1914.

429. Notes on Agelacrinidæ and Lepadocystinæ, with descriptions of Thresherodiscus and Brockocystis: Denison Univ., Sci. Lab., Bull., vol. 17, pp. 399-474, 6 pls., 8 figs., September, 1914.

Preliminary report on the Waverlian formations of east central Kentucky and their economic values. See Morse and Foerste, no. 867.

Fohs, F. Julius.

430. Barytes deposits of Kentucky: Kentucky Geol. Survey, Fourth Series, vol. 1, pp. 441-588, 8 figs., 2 pls., 2 maps, 1913.

Foote, H. W., and Bradley, W. M.

431. On solid solution in minerals; V, The isomorphism between calcite and dolomite: Am. Jour. Sci., 4th ser., vol. 37, pp. 339-345, April, 1914.

Ford, W. E.

432. A contribution to the optical study of the amphiboles: Am. Jour. Sci., 4th ser., vol. 37, pp. 179-193, 11 figs., February, 1914; Zeitschr. Kryst. Min., Bd. 54, H. 1, pp. 1-16, 11 figs., 1914.

433. Mineral notes: Am. Jour. Sci., 4th ser., vol. 38, pp. 502-504, December, 1914.

Foshay; P. Maxwell.

434. A moraine of Kansan or Nebraskan age at Jackson, New Hampshire: Am. Jour. Sci., 4th ser., vol. 38, pp. 345-348, 1 fig: (map), October, 1914.

Foye, J. C.

435. Hand-book of mineralogy; determination, description, and classification of minerals found in the United States, 5 th ed., $180 \mathrm{pp}$., New York, D. Van Nostrand Company, 1907.

Frear, William.

436. Pennsylvania limestone and lime supplies: Pennsylvania State Coll. Agr. Exp. Station, Bull. no. 127, pp. 71-106, December, 1913.

Fréchette, Howells.

437. Report on the nonmetallic minerals used in the Canadian manufacturing industries: Cañada, Dept. Mines, Mines Branch, $199 \cdot$ pp., 1914.

Free, E. E.

438. Sketch of the geology and soils of the Cahuilla Basin: Carnegie Inst., Washington, Pub. no. 193 (MacDougal, The Salton Sea), pp. 21-33, 3 pls., 1914.

439. The topographic features of the desert basins of the United States, with reference to the possible occurrence of potash: U. S. Dept. Agr., Bull., no. 54, 65 pp., 6 pls., 1 map, May 8, 1914.

French, Harold.

440. Genesis and revelations of the Yosemite Valley: Pop. Sci. Monthly, vol. 85, no. 1, pp. 69-82, 7 figs., July, 1914.

Fuller, Myron L.

441. The geology of Long Island, New York: U. S. Geol. Survey, Prof. Paper 82, 231 pp., 27 pls. (incl. maps), 205 figs., 1914; (abstract by A. H. Brooks), Washington Acad. Sci., Jour., vol. 4, no. 9, pp. 224-225, May 4, 1914.

Gale, Hoyt S.

442. Notes on the Quaternary lakes of the Great Basin, with special reference to the deposition of potash and other salines: U. S. Geol. Survey, Bull. 540, pp. 399-406, 1914. 
Gale, Hoyt S.-Continued.

443. Prospecting for potash in Death Valley, California: U. S. Geol. Survey, Bull. 540, pp. 407-415, 1 fig., 1914.

444. Salt, borax, and potash in Saline Valley; Inyo County, California: U. S. Geol.

' Survey, Bull. 540, pp. 416-421, 1 fig., 1914.

445. Potash tests at Columbus Marsh, Nevada: U. S. Geol. Survey, Bull. 540, pp. 422-427, 1914.

446. Sodium sulphate in the Carrizo Plain, San Luis Obispo County, California: U. S. Geol. Survey, Bull. 540, pp. 428-433, 2 figs., 1914.

447. Borate deposits in Ventura County, California: U. S. Geol. Survey, Bull. 540, pp. 434-456, 1 pl. (map), 2 figs., 1914.

448. Late developments of magnesite deposits in California and Nevada: U. S. Geol. Survey, Bull. 540, pp. 483-520, 1 pl., 11 figs., 1914.

449. Salines in the Owens; Searles, and Panamint basins, southeastern California: U. S. Geol. Survey, Bull. 580, pp. 251-323, 3 pls., 31 figs., 1914.

Magnesite; borax. See Yale and Gale, no. 1351.

Gale, Hoyt S., and Hicks, W. B.

450. Octahedral crystals of sulphohalite: Am. Jour. Sci., 4th ser., vol. 38, pp. 273-274, September, 1914.

Galloway, J. J.

The stratigraphy and paleontology of the Tanners Creek section of the Cincinnati series of Indiana. See Cumings and Galloway, no. 295.

Gardner, E. D.

451. New World mining district [Park County, Montana]: Min. and Sci. Press, vol. 108, no. 22, pp. 880-884, map, 3 figs., May 30, 1914.

Gardner, James H.

452. The Broadtop coal field of Huntingdon, Bedford, and Fulton counties: Pennsylvania Topog. and Geol. Survey, Rept. no. 10, 81 pp., 32 pls. (incl. maps and sections in pocket), 1913.

453. Geology of the Broadtop coal field: Pennsylvania Geol. Survey, [col. map], scale, 1: 24,000 [1914].

Garfias, V. R.

Geology and technology of the California oil fields. See Arnold and Garfias, no. 21 .

George, R. D.

454. Geologic map of Colorado, scale, 1:500,000: Colorado State Geol. Survey, 1913.

Gester, G. C.

455. Geology of the southern end of the San Joaquin Valley (abstract): Geol. Soc. America, Bull., vol. 25, no. 1, p. 123, March 30, 1914.

\section{Gibson, Thomas W.}

456. Report of the Bureau of Mines, 1914: Ontario, Bureau of Mines, Twenty-third Ann. Rept., vol. 23, pt. 1, 300 pp., illus., Toronto, 1914.

Gidley, J. W.

457. Fauna of the Cumberland Pleistocene cave deposit (abstract, with discussion): Geol. Soc. America, Bull., vol. 25, no. 1, p. 142, March 30, 1914.

Gilbert, Grove Karl.

458. The transportation of débris by running water: U. S. Geol. Survey, Prof. Paper 86, 263 pp., 3 pls., 89 figs., 83 tables, 1914. Abstract, Washington Acad. Sci., Jour., vol. 4, no. 7, pp. 154-158, April 4, 1914. 
Gilbert, Grove Karl-Continued.

458. Interpretation of anomalies of gravity: U. S. Geol. Survey, Prof. Paper 85 , pp. 29-37, 1. pl. (map), fig. 7, 1913; (abstract) Washington Acad. Sci.', Jour., vol. 4, no. 8, p. 192, April 19, 1914.

Gilmore, Charles Whitney.

460. Osteology of the armored Dinosauria in the United States National Museum, with special reference to the genus Stegosaurus: U. S. Nat. Mus., Bull. 89, 136 pp., 37 pls., 73 figs., 1.914.

461. A second occurrence of ichthyosaurian remains in the Benton Cretaceous: Science, new ser., vol. 39, p. 210, February 6, 1914.

462. A new ceratopsian dinosaur from the Upper Cretaceous of Montana, with note on Hypacrosaurus: Smithsonian Misc. Coll., vol. 63, no. 3, 1.0 pp., 2 pls., 3 figs., March 21, 1914.

Describes Brachyceratops montanensis new genus and new species.

Girty, George H.

463. On the names of American fusulinas: Jour. Geology, vol. 22, no. 3, pp. 237242, April-May, 1914.

Gleason, Frank A.

464. Occurrence of coal in the northern anthracite fields [Pennsylvania]: Penn State Min. Quart., vol. 2, no. 1, pp. 3-24, October, 1914.

Glenn, I. C.

465. A tripoli deposit near Butler, Tennessee: Tennessee State Geol. Survey, Resources of Tennessee, vol. 4, no. 1, pp. 29-35, January, 1914.

466. The tripoli deposits of Tennessee (abstract): Science, new ser., vol. 39, p. 403, March 13, 1914.

467. An unnoticed physiographic feature in Tennessee (abstract,: Tennessee Acad. Sci., Trans., vol. 1, p. 73, August 1, 1914.

Goldman, M. I.

468. Petrographic evidence on the origin of the Catahoula sandstone (abstract): Washington Acad. Sci., Jour., vol. 4, no. 11, pp. 296-298, June 4, 1914.

Goldsberry, J. P.

The chemical composition of bornite and its relation to other sulpho-minerals. See Kraus and Goldsberry, no. 696.

Goldthwait, James Walter.

469. Marine shore lines in southeastern Quebec: Canada Geol. Survey, Summ. Rept., 1912, pp. 357-359, 1914.

470. Marine submergence at Montreal, Covey Hill, and Rigaud Mountain [Quebec]: Canada Geol. Survey, Summ. Rept. 1913, p. 211, 1914.

471: Physiography and surficial geology of Nova Scotia: Canada Geol. Survey, Summ. Rept. 1913, pp. 244-250, 1914.

472. Remnants of an old graded upland on the Presidential Range of the White Mountains: Am. Jour. Sci., 4th ser., vol. 37, pp. 451-463, 4. figs. (incl. maps), May, 1914.

473. Supposed evidences of subsidence of the coast of New Brunswick within modern time: Canada Geol. Survey, Mus. Bull. no. 2, pp. 45-67, 1 fig. (map), June 19, 1914.

474. Occurrence of glacial drift on the Magdalen Islands [Gulf of Saint Lawrence] (abstract): Geol. Soc. America, Bull., vol. 25, no. 1, p. 84, March 30, 1914.

Goodale, Charles W.

475. The Drumlummon mine, Marysville, Montana: Am. Inst. Min. Eng., Bull., no. 92, pp. 2095-2120, 12 figs., August, 1914. 
Gordon, C. E.

476. Notes on the geology in the vicinity of Bennington, Vermont: Vermont, State Geologist, Ninth Rept., pp. 337-370, 7 pls. (incl. map), 9 figs., 1914.

Gordon, C. H.

477. Earthquakes in east Tennessee: Tennessee State. Geol. Survey, Resources of Tennessee, vol. 4, no. 1, pp. 15-22, 1 map, January, 1914.

478. The copper resources of the Southern States (abstract): Science, new ser., vol. 39, p. 403, March 13, 1914.

479. Types of iron ore deposits in east Tennessee (abstract): Tennessee Acad. Sci., Trans., vol. 1, pp. 69-70, August 1, 1914.

Gould, Chas. N.

480. The occurrence of petroleum and natural gas in the mid-continent field: Int. Geol. Cong., XII, Canada, 1913, C. R., pp. 861-868, 1914.

Gow, James Ellis.

481. Preliminary note on the so-called "loess" of southwestern Iowa: Iowa Acad. Sci., Proc., vol. 20, pp. 221-230, 1913.

Grabau, Amadeus W.

482. Preliminary report on the fauna of the Dundee limestone of southern Michigan: Michigan Geol. and Biol. Survey, Pub. 12 (Geol. Ser. 9), pp. 327$378,1913$.

483. Irrational stratigraphy; the right and the wrong way of reconstructing ancient continents and seas (abstract, with discussion): New York Acad. Sci., Annals, vol. 23, p. 288, April 30, 1914.

Graham, R. P. D.

484. [Geological map of] coast and islands between Queen Charlotte Sound and Burke Channel, British Columbia: Canada Geol. Survey, Map 92A, 1913. Scale 1: $253,440$.

Über die Krystallisation des Willemits. See Palache and Graham, no. 910.

Yukonite, a new hydrous arsenate of iron and calcium, from Tagish Lake, Yukon Territory, Canada; with a note on the associated symplesite. See Tyrrell and Graham, no. 1198.

Granger, Walter.

485. On the names of lower Eocene faunal horizons of Wyoming and New Mexico: Am. Mus. Nat. Hist., Bull., vol. 33, pp. 201-207, 1914.

486. Lower Eocene faunæ of northwestern Wyoming (abstract): -New York Acad. Sci., Annals, vol. 23, p. 263, April 30, 1914.

Paleocene deposits of the San Juan basin, New.Mexico. See Sinclair and Granger, no. 1093.

Grant, U. S., and Cady, G. H.

487. Preliminary report on the general and economic geology of the Baker district of eastern Oregon: Oregon Bur. Mines and Geology, Mineral Resources of Oregon, vol. 1, no. 6, pp. 129-161, 4 pls., 3 figs., October, 1914.

Grant, U. S., and Higgins, D. F.

488. Coastal glaciers of Prince William Sound and Kenai Peninsula, Alaska (abstract by A. H. Brooks): Washington Acad. Sci., Jour., vol. 4, no. 8, p. 193, April 19, 1914. 
Grasty, J. S.

489. The limestones of Maryland, east of the Blue Ridge (abstract): Science, new ser., vol. 39, p. 399, March 13, 1914.

The Piedmont limestones of the southeast Atlantic States (abstract). See Watson and Grasty, no. 1263.

The cement materials and industry. of the Southern States (abstract). See Watson and Grasty, no. 1264.

Grasty, J. S., and Cline, J. H.

490. The slate deposits of the Southern States (abstract): Science, new ser., vol. 39, pp. 399-400, March 13, 1914.

Gratacap, L. P.

491. Tertiary fossils on Long Island: Nautilus, vol. 28 , no. 8, pp. 85-86, December, 1914.

Graton, L. C.

492. Notes on rocks from the Coppermine River region, Canada: Canadian Min. Inst., Trans., vol. 16, pp. 102-114, 1913.

Graton, L. C., and Murdoch, Joseph.

The sulphide ores of copper; some results of microscopic study (with discussion): Am. Inst. Min. Eng., Trans., vol. 45, pp. 26-93, 529-530, 36 figs., 1914. See no. 437 of the bibliography for 1913, U. S. Geol. Survey, Bull. 584 .

\section{Greenan, James 0 .}

493. Geology of Fairview, Nevada: Eng. and Min. Jour., vol. 97, no. 16, pp. 791793, 3 figs., April 18, 1914.

Greene, F. C.

494. The coal resources of a part of northeastern Missouri: U. S. Geol. Survey, Bull. 541, pp. 223-242, 1 fig. (map), map, 1914.

Greenland, C. W.

495. On the origin and structure of the carbonaceous schists of the Lake of the Woods [Ontario]: Canadian Min. Inst., Trans., vol. 16, pp. 584-597, 2 pls., 2 figs., 1913.

Greger, Darling K.

496. On the retention of the original color ormamentation in fossil brachiopods: Nautilus, vol. 28, no. 8, pp. 93-95, December, 1914.

Gregory, Herbert E.

497. A reconnaissance of a portion of the Little Colorado Valley, Arizona: $\Lambda \mathrm{m}$. Jour. Sci., 4th ser., vol. 38, pp. 491-501, 7 figs., December, 1914.

Gregory, W. K.

498. Skeleton of Notharctus, an Eocene lemuroid (abstract): Geol. Soc. America, Bull., vol. 25, no. 1, p. 141, March 30, 1914.

Gregory, W. K., and others.

498. Conference on convergent evolution, including a summary of the recent discussion before the British Association for the Advancement of Science (abstract): New York Acad. Sci., Annals, vol. 23, pp. 293-299, April 30, 1914.

Grier, Norman McDowell.

500. A preliminary list of the fossil plants occurring in the roof of the Pittsburgh coal: Carnegie Mus., Annals, vol. 9, nos. 1-2, pp. 125-128, September, 1914. 
Grothe, A., and Salazar S., L.

501. La industria minera de México, no. 5 [tomo 2, pt.. 1]; Estado de Michoacán, primera parte, pp. 1-83, pls. and maps, Mexico, 1912.

An account of the mining industry, including notes on the geology, of the state of Michoacan. For the second part see Salazar, no. 1022.

Grout, Frank F., and Soper, E. K.

502. Preliminary report on the clays and shales of Minnesota: Minnesota Geol. Survey, Bull. no. 11, 175 pp., 7 pls. (incl. map), 14 figs., 1914.

Gutiérrez Lanza, R. P. Mariano.

503. Conferencias de seismologia [lectures on seismology]: Acad. Cienc. Med., Fis. Nat., Habana, Ạnales, Rev. cient., vol. 50, pp. 271-291, 3 figs., August-September, 1913; (reprinted), xvi, 157 pp., 32 pls. Habana, Imp. de Lloredo y ca., 1914.

Haanal, Eugene.

504. Director's general report of the Mines branch of the Department of Mines for the calendar year ending December 31, 1913: Canada, Dept. Mines, Mines Branch, Summ. Rept. 1913, pp. 1-22, 1914.

Hackett, Edward F.

505. The coal field of Sebastian County, Arkansas: Coal Age, vol. 6, no. 16, pp. 630631, 1 fig. (map), October 17, 1914.

Hafer, Claud.

506. Copper Creek district of Arizona: Eng. and Min. Jour., vol. 98, no. 26, p. 11.45, 1 fig., December 26, 1914.

Hager, Dorsey.

507. Anticlinal dome structure in. California oil fields: Western Eng., vol. 4, no. 1, pp. 28-30, 1 fig., January, 1914.

508. Effects of faulting in oil fields: Western Eng., vol. 4, no. 6, pp. 442-445, 10 figs., June, 1914.

509. Unconformities and overlap and their effects on oil fields: Western Eng., vol. 5, no. 4, pp. 168-169, 5 figs., October, 1914.

Halberstadt, Baird.

510. The coals of the Pocono (No. X) formation in Pennsylvania: Pennsylvania Dept. Agr., Nineteenth Ann. Rept., pp. 404-408, 1914.

Hance, James H.

511. Potash in western saline deposits: U. S. Geol. Survey, Bull. 540, pp. 457$469,1914$.

Hannibal, Harold.

Dickerson on California Eocene. See Arnold and Hannibal, no. 22.

Harding, W. K.

512. Rice Lake gold mining district, Manitoba, Canada: Min. and Eng. World; vol. 40, no. 25, pp. 1154-1155, June 20, 1914.

Hardinge, H. W.

513. Kirkland Lake district, Ontario, Canada: Eng. and Min. Jour., vol. 38, no. 14 , p. 619 , October 3,1914 .

Gives notes on the occurrence of gold deposits. $i$

1

Harker, Alfred.

514. Fractional crystallization the prime factor in the differentiation of rock magmas: Int. Geol. Cong., XII, Canada, 1913, C. R., pp. 205-208, 1914. 
Harnsberger, T. K.

Examples of intercision type of stream piracy in western Virginia. See Watson, Cline, and Harnsberger, no. 1265.

Harvie, Robert.

515. Geology of Orford map area, and the southern part of the "serpentine belt," Potton Township, Quebec: Canada Geol. Survey, Summ. Rept. 1913, pp. 212-216, 1914.

Hatch, F. H.

516. The relation of geology to mining: Econ. Geology, vol. 9, no. 3, pp. 205-235, April, 1914.

Haultain, H. E. T.

517. The geologist: Canadian Min. Inst., Trans., vol. 16, pp. 545-564, 1913.

\section{Hawaiian Volcano Observatory.}

518. Report of the Hawaiian Volcano Observatory of the Massachusetts linstitute of Technology and the Hawaiian Volcano Research Association, T. A. Jaggar, Director. January-March, 1912. Published by the Society of Arts of the Massachusetts Institute of Technology, Boston. 74 pp., 92 figs. [1914].

519. Weekly Bulletin, vol. 2, nos. 1-32, Jaunary 7, 1914-December 31, 1914.

Hawkins, A. C.

520. Lockatong formation of the Triassic of New Jersey and Pennsylvania: New York Acad. Sci., Annals, vol. 23, pp. 145-176, 1 pl. (map), 1 fig., 1914.

Haworth, Erasmus.

521. Special report on well waters in Kansas: Kansas Univ. Geol. Survey, Bull. no. 1,.103 pp., 6 pls. (maps and sections), 9 figs., 1913.

Hay, Oliver $P$.

522. The Pleistocene mammals of Iowa: Iowa Geol. Survey, vol. 23, 662 pp., 75 pls., 142 figs., 1914.

Hayes, Albert 0 .

523. Geology of the St. John map area, New Brunswick: Canada Geol. Survey, Summ. Rept.' 1913, pp. 228-243, 1914.

524. Geology of the Wabana iron ore of Newfoundland (abstract): Geol. Soc. America, Bull., vol. 25, no. 1, p. 74, March 30, 1914.

Healy, John R.

The' geology of New York City and its relations to engineering problems (with discussion). See Berkey and Healy, no. 79.

Hechinger, L. A.

An unconformity in the Narragansett Basin of Rhode Island and Massachusetts. See Loughlin and Hechinger, no. 767.

Henderson, 'Junius.

525. Recent progress in Colorado paleontology and stratigraphy: Colorado Sci. Soc., Proc., vol. 11, pp. 5-22, November, 1914.

Hennen, Ray V.

526. General section, Kanawha series, Kanawha County [West Virginia]: West Virginia Geol. Survey, Kanawha County, pp. xxvi-xxviii, 1914.

Hennen, Ray V., and Reger, David B.

527. Preston County [West Virginia]: West Virginia Geol. Survey, County Reports, 566 pp., 43 pls., 10 figs., 3 maps (in atlas), 1914. 
Hess, Frank L.

528. A hypothesis for the origin of the carnotites of Colorado and Utah: Econ. Geology, vol. 9, no. 7, pp. 675-688, October, 1914; (abstract), Washington Acad. Sci., Jour., vol. 4, no. 9, p. 236, May 4, 1914.

529. Antimony; arsenic; bismuth; selenium and tellurium; cobalt; molybdenum; nickel; tin; titanium; tungsten; radium, uranium, and vanadium: U. S. Geol. Survey, Mineral Resources, 1913, pt. 1, pp. 279-289, 339-364, 1914.

Hess, Frank L., and Schaller, Waldemar T.

530. Colorado ferberite and the wolframite series: U. S. Geol. Survey, Bull. 583, 75 pp., 14 pls., 35 figs., 1914.

531. Pintadoite and uvanite, two new vanadium minerals from Utah: Washington - Acad. Sci., Jour., vol. 4, no. 20, pp. 576-579, December 4, 1914.

Hewett, D. F.

532. The ore deposits of Kirwin, Wyoming: U. S. Geol. Survey, Bull. 540, pp. 121-132, 3 figs., 1914.

533. Sulphur deposits in Park County, Wyoming: U. S. Geol. Survey, Bull. 540, pp. 477-480, 1914.

534. The Shoshone River section, Wyoming: U. S. Geol. Survey, Bull. 541, pp. 89-113, 1 pl., 1914.

535. Manganese and manganiferous ores: U. S. Geol. Survey, Mineral Resources, 1913, pt. 1, pp. 57-74, 1914.

Geology and mineral resources of the Sumpter quadrangle, Oregon. See Pardee and Hewett, no. 918.

Hicks, W. B.

Octahedral crystals of sulphohalite. See Gale and Hicks, no. 450.

Searlesite, a new mineral [San Bernardino County, California]. Sec Larsen and Hicks, no. 717.

Higgins, D. F.

536. Field and office methods in the preparation of geologic reports; secondary silicate zonies: Econ. Geology, vol. 9, no. 1, pp. 73-77, January, 1914.

Coastal glaciers of Prince William Sound and Kenai Peninsula, Alaska (abstract by A. H. Brooks). See Grant and Higgins, no. 488.

Hill, James M.

537. Copper deposits of the White Mesa district, Arizona: U. S. Geol. Survey, Bull. 540, pp. 159-163, 1914.

538. The Yellow Pine mining district, Clark County, Nevada: U. S. Geol. Survey, Bull. 540, pp. 223-274, 1 pl. (map), 6 figs., 1914.

539. The Grand Gulch mining region, Mohave County, Arizona: U. S. Geol. Survey, Bull. 580, pp. 39-58, 5 figs. (incl. map), 1914.

540. Mineral paints; barytes; strontium: U. S. Geol. Survey, Minęral Resources, 1913, pt. 2, pp. 49-70, 165-174, 1 fig. (map), 1914.

Hillebrand, W. F., Merwin, H. E., and Wright, Fred. E.

541. Hewettite, metahewettite, and pascoite, hydrous calcium vạadates: Am. Philos. Soc., Proc., vol. 53, pp. 31-54, 2 figs., 1914.

Hills, Richard C.

542. On a probable eighth fragment of the Glorieta meteorite: Colorado Sci. Soc., Proc., vol. 11, pp. 1-4, 2 pls., August, 1914.

Hinds, Henry.

543. Oil and gas in Colchester and Macomb quadrangles: Illinois State Geol. Survey, Extr. Bull. 23, pp. 8-13, 1 pl. (map), 1914. 
Hixson, W. A.

544. Analyses of Iowa coals with a discussion of their physical and chemical properties from the industrial view point: Iowa Geol. Survey, Ann. Rept., vol. 24, pp. 687-763, 1.pl. (map), 1914.

Hobbs, William Herbert.

545. Variations in composition of pelitic sediments in relation to magmatic differentiation: Int. Geol. Cong., XII, Canada, 1913, C. R., pp. 241-246, 1914.

546. Mechanics of formation of arcuate mountains: Jour. Geology, vol. 22, pp. 71-90, 166-188, 193-208, 39 figs., 1914; (abstract), Geol. Soc. America, Bull., vol. 25, no. 1, pp. 30-31, March 30, 1914.

547. Buried lava tunnels as a factor in the drainage of craters of the Hawaiian type: Zeitschr. Vulkanologie, Bd. 1, H. 2, pp. 86-88, 1 pl., 2 figs., May, 1914.

548. Simple directions for the determination of the common minerals and rocks; a laboratory course in general geology. 31 pp., 8 figs., 1 pl. New York, The Macmillan Company, 1914.

549. Eduard Suess: Jour. Geology, vol. 22, no. 8, pp. 811-817, 2 pls. (ports.), November-December, 1914.

Hodge, James M.

550. Report on the coals of the headwaters of Licking River, Magoffin County [Kentucky]: Kentucky Geol. Survey, Fourth Series, vol. 1, pp. 889921, 1913.

551. Coals on the north side of the North Fork of Kentucky River in Perry and Knott counties [Kentucky]: Kentucky Geol. Survey, Fourth Series, vol. 1, pp. 923-986, 1913.

552. The coals of the upper Carr Fork and Big Branch and Bull Creek region of North Fork of Kentucky River: Kentucky Geol. Survey, Fourth Series, vol. 1, pp. 987-1036, 1913.

Höfer, Hans von.

553. The origin of petroleum (translation): Am. Inst. Min. Eng., Bull., no. 89, pp. 869-880, May, 1914; Trans., vol. 48, pp. 481-503, 1915.

Hoeing, J. B.

554. [First annual report]: Kentucky Geol. Survey, Fourth Series, vol. 1, pp. $1-78,1913$.

555. The coals of the upper Big Sandy Valley and the headwaters of the North Fork of the Kentucky. River; Kentucky Geol. Survey, Fourth Series, vol. 1, pp. 79-261, 1913.

556. Coal analyses in the western coal field [Kentucky]: Kentucky Geol. Survey, 4th ser., vol. 2, pt. 1, pp. 219-414, 1914.

Holden, Ruth.

557. Contributions to the anatomy of Mesozoic conifers; No. 2, Cretaceous lignites from Cliffwood, New Jersey; Bot. Gazette, vol. 58, no. 2, pp. 168-177, 4 pls., August, 1914.

Holland, Thoinas H.

558. The earth's crust: Science, new ser., vol. 40, pp. 533-541, October 16, 1914.

Holland, W. J., and Peterson, O. A.

559. The osteology of the Chalicotheroidea: Carnegie Mus., Mem., vol. 3, no. 2, pp. 189-406, 30 pls., 115 figs., December, 1913.

Hollick, Arthur.

560. The paleobotanical collections of the New York Botanical Garden: Am. Assoc. Museums, Proc., vol. 4, pp. 43-52, 1911: New York Bot. Garden, Contr. no. 144. 1911. 
Hollick, Arthur-Continued.

561. A preliminary report upon the plants from the Pleistocene deposits [of East Kootenay, British Columbia]: Canada Geol. Survey, Summ. Rept. 1913, pp. 133-135, 1914.

Holtedahl, Olaf.

562. On the fossil faunas from Per Schei's Series B in southwestern Ellesmere Land: Second Norwegian Arctic Expedition in the Fram, 1898-1902, Rept., no. 32, 48 pp., 8 pls., 2 maps, 1914.

Holway, Ruliff S.

563. The effect of seven years' erosion on the California fault line of 1906: Am. Geog. Soc., Bull., vol. 46, no. 6, pp. 420-426, 3 figs., June, 1906.

564. Physiographically unfinished entrances to San Francisco Bay: California, Univ., Pub. Geography, vol. 1, no. 3, pp. 81-126, 9 pls. (incl. map), 2 sketch maps, April 4, 1914.

565. Preliminary report on the recent volcanic activity of Lassen Peak [California]: California, Univ., Pub. Geography, vol. 1, no. 7, pp. 307-330, 5 pls., August 7, 1914; Am. Geog. Soc., Bull., vol. 46, no. 10, pp. 740755, 7 figs., October, 1914.

566. Apparent limits of former glaciation in the northern coast ranges of California (abstract): Geol. Soc. America, Bull., vol. 25, no. 1, pp. 120-121, March 30, 1914.

Hook, J. S.

567. The brown and blue phosphate deposits of south-central Tennessee: Tennessee State Geol. Survey, Resources of Tennessee, vol. 4, no. 2, pp. 51-83, 12 figs., map, April, 1914.

Hopkins, Oliver B.

568. A report on the asbestos, talc, and soapstone deposits of Georgia: Georgia Geol. Survey, Bull. no. 29,. 319 pp., 21 pls., 7 figs., map, 1914.

569. Asbestos deposits of Georgia: Am. Inst. Min. Eng., Bull., no. 93, pp. 22752284, 3 figs., September, 1914; (abstract) Science, new ser., vol. 39, p. 402, March 13, 1914.

Hopkins, Percy E.

The Kirkland Lake and Swastika gold areas and Maisonville, Grenfell, and Eby townships. See Burrows and Hopkins, no. 164.

Hopkins, Thomas Cramer.

570. Elements of physical geography. 484 pp., 316 figs. Boston, Benj. H. San. born \& Co. [1908].

571. The geology of the Syracuse quadrangle [New York]: New York State Mus., Bull. 171, 80 pp., 20 pls., 5 figs., geol. map, 1914.

572. High-level loop channel (abstract): Geol. Soc. America, Bull., vol. 25, no. 1, p. 68, March 30, 1914.

Hore, Reginald, E.

573. The Michigan copper industry in 1913: Michigan Geol. and Biol. Survey, Pub. 16 (Geol. ser. 13), pp. 11-37, 1914.

574. Magmatic origin of Sudbury nickel-copper deposits : Canadian Min. Inst., Quart. Bull., no. 21, pp. 85-96, March, 1913; Canadian Min. Inst., Trans., vol. 16, pp. 271-282, 1913.

575. Gold deposits of Porcupine district, Ontario: Michigan Acad. Sci., 15th Rept., pp. 54-58, 1913.

576. Ripple-marked Huronian quartzite, at Nipissing mine, Cobalt, Ontario: Michigan Acad. Sci., 15th Rept., p. 59, 2 pls., 1913. 


\section{Houghton, Frederick.}

577. The geology of Erie County [New York]: Buffalo Soc. Nat. Sci., Bull:, vol. 11, no. 1, pp. 3-84, 45 figs., 1 map, tables of fossils, 1914.

Hovey, Edmund Otis.

578. Proceedings of the twenty-sixth annual meeting of the Geological Society of America, held at Princeton, New Jersey, December 30, and 31, 1913, and January 1, 1914: Geol. Soc: America, Bull., vol. 25, no. 1, pp. 1-118, March 30, 1914.

579. Note on landslides: Int. Geol. Cong., XII, Canada, 1913, C. R., pp. 793$795,1914$.

Hovey, Horace Carter, and Call, Richard Ellsworth.

580. Bibliographie chronologique et analytique de Mammoth Cave, Kentucky, États-Unis d'Amérique, 1815 a 1914, traduite et ordonnée par E. A. Mằrtel: Spelunca, t. 9, no. 73, pp. 3-49, Paris, July, 1914.

Annotated bibliography of Mammoth Cave arranged chronologically under subdivisions of the subject.

Howard, L. 0.

581. The development of our radium-bearing ores: Assoc. Eng. Soc., Jour., vol. 52, no. 4, pp. 185-216, map, 8 figs., April, 1914.

Howe, Ernest.

582. Landslides and the sinking of ground above mines: Int. Geol. Cong., XII, Canada, 1913, C: R., pp. 775-778, 1914.

583. Petrographical notes on the Sudbury [Ontario] nickel deposits: Econ. Geology, vol. 9, no. 6, pp. 505-522, 1 pl., 3 figs., September, 1914.

Hoyt, B. F.

584. The Judith Mountains, Fergus County, Montana: Min. and Eng. World, vol. 41, no. 21, pp. 957-958, 2 figs., November 21, 1914.

' Huard, V. A.

585. Abrégé de géologie. 155 pp., 75 figs., Quebec, 1913. Review by Vernon L.

Kellogg, under the title, A modern textbook of geology - and evolution, in Science, new ser., vol. 39, pp. 64-67, January 9, 1914.

Hubbard, George D.

586. Tilted shore lines of ancient Craigton Lake, Ohio: Science, new ser., vol. 39, pp. 470-471, March 27, 1914.

587. A Finger Lake bed in Ashland and Wayne counties, Ohio, with tilted shore lines: Am. Jour. Sci., 4th ser., vol. 37, pp. 444-450, 2 figs. (incl. map), May, 1914.

Huene, Friedrich von.

588. Über Lysorophus aus dem Perm von Texas: Anatomischer Anzeiger, Bd. 43; no. 14-15, pp. 389-396, 4 figs., March, 1913.

589. The dinosaurs not a natural order: Am. Jour. Sci., 4th ser., vol. 38, pp. 145146, August; 1914.

590. Beiträge zur Geschichte der Archosaurier: Geol. u. Pal. Abh., N. F., Bd. 13, H. 1, pp. 1-53, 7 pls., 61 figs., 1914.

\&: Includes discussion of $A$ merican forms.

591. Beiträge zur Kenntnis des Schädels einiger Pterosaurier: Geol. u. Pal. Abh. N. F., Bd. 13, H. 1, pp. 55-65, 2 pls., 10 figs., 1914.

$\because$ Includes discussion of American forms.

592. Nachträge zu meinen früheren Beschreibungen triassischer Saurischia: Geol. u. Pal. Abh., N. F., Bd. 13, H. 1, pp. 67-82, 56 figs., 1914.

Additional observations on Triassic Saurischia, mainly American material. 
Huene, Friedrich von-Continued.

593. Über die Zweistämmigkeit der Dinosaurier, mit Beiträgen zur Kenntnis einiger Schädel: Neues Jahrb., Beilage Bd. 37, H. 3, pp. 577-589, 6 pls., 1914.

Describes American material and discusses the derivation of the Dinosauria.

\section{Humphreys, Edwin W.}

594. Some fossil leaves and their significance: Torreya, vol. 14, no. 3, pp. 39-42, 2 pls., March, 1914.

Hunter, J. Fred.

595. The Aberdeen granite quarry near Gunnison, Colorado: U. S. Geol. Surver, Bull. 540, pp. 359-362, 1914.

596. Some cerusite deposits in Custer County, Colorado: U. S. Geol. Survey, Bull. 580, pp. 25-37, 2 figs., 1914.

597. Erosion and sedimentation in Chesapeake Bay around the mouth of Choptank River [Maryland]: U. S. Geol. Survey, Prof. Paper 90-B, pp. 7-15, 1 pl. (map), 1 fig., May 23, 1914; (abstract), Washington Acad. Sci., Jour., vol. 4, no. 14, pp. 421-422, August 19, 1914.

Melilite and other minerals from Gunnison County, Colorado. See Larsen and Hunter, no. 718.

Huntington, Edward V.

The faultless faultfinder. See Weeks and Huntington, no. 1267.

Huntington, Ellsworth.

598. The climatic factor as illustrated in arid America: Carnegie Inst. Washington, Pub. no. 192, 341 pp., 12 pls., 2 maps, 90 figs., 1914.

599. The solar hypothesis of climatic changes: Geol. Soc. America, Bull., vol. 25, no. 4, pp. 477-590, 23 figs., December, 1914; (abstract), Geol. Soc. America, Bull., vol. 25, no. 1, pp. 82-83, March 30, 1914.

Hutchinson, F. M.

600. Report on the geology and coals of the Central City, Madisonville, Calhoun, and Newberg quadrangles, in Muhlenberg, Hopkins, Ohio, McLean, Webster, Daviess, and Henderson counties: Kentucky Geol. Survey, Bull. no. 19, 127 pp., 4 maps, 6 sections, 1912.

Hyde, Jesse E.

601. The stratigraphic relations of the Riversdale-Union and Windsor formations of Nova Scotia: Canada Geol. Survey, Summ. Rept., 1912, pp. 390396, 1914.

602. The Windsor-Pennsylvanian section on the Strait of Canso, Nova Scotia: Canada Geol. Survey, Summ. Rept. 1913, pp. 264-269, 1914.

Iddings, Joseph $\mathrm{P}$.

603. The problem of volcanism. xi, 273 pp., 86 figs., map. New Haven, Yale University Press, 1914.

604. Some examples of magmatic differentiation and their bearing on the problem of petrographical provinces: Int. Geol. Cong., XII, Canada, 1913, C. R., pp. 209-228, 12 figs., 1914.

605. Igneous rocks and their origin, by Reginald Aldworth Daly; review: Science. new ser., vol. 40, pp. 710-715, November 13, 1914.

606. The study of igneous rocks: Australasian Assoc. Adv. Sci., Rept.. Twelfth Meet., Brisbane, 1909, pp. 265-282, 1910. 
Ingall, E. D.

607. Borehole records (water, oil, etc.): Canada Geol. Survey, Summ. Rept. 1912, pp. 415-416, 1914.

608. Borehole records (water, oil, etc.): Canada Geol. Survey, Summ. Rept. 1913, pp. 331-332, 1914.

International Geological Congress.

609. Compte-Rendu de la XII session, Canada, 1913. 1034 pp., il., Ottawa, 1914.

Irving, J. D., and Bancroft, Howland.

610. Geology and ore deposits near Lake City, Colorado (abstract by A. H. Brooks): Washington Acad. Sci., Jour., vol. 4, no. 8, pp. 193-194, April 19, 1914.

Jacobs, Elbridge Churchill.

611. Talc, and the talc deposits of Vermont: Vermont, State Geologist, Ninth Rept., pp. 382-429, 3 pls. (incl. map), 7 figs., 1914.

Jaggar, 'T. A., jr.

612. Scientific work on Hawaiian volcanoes: Hawaiian Volcano Observatory, Special Bull., 15 pp., 1913.

See also Hawaiian Volcano Observatory, nos. 518, 519.

Jeffrey, Edward Charles.

613. On the composition and qualities of coal: Econ. Geology, vol. 9, no. 8, pp. 730-742, 4 pls., 1 fig., December, 1914.

614. Improvements in methods of investigating highly carbonized materials and their bearing on -the mode of deposition of coal (abstract): Geol. Soc. America, Bull., vol. 25, no.1, p. 58, March 30, 1914.

On fossil plants showing structure from the base of the Waverly shale of Kentucky. See Scott and Jeffrey, no. 1061.

Johannsen, Albert.

615. Petrographic analysis of the Bridger, Washakie and other Eocene formations of the Rocky Mountains, with introductory note by W. D. Matthew: Am. Mus. Nat. Hist., Bull., vol. 33, pp. 209-222, 2 figs., 1914.

616. Petrological abstracts and reviews: Jour. Geology, vol. 22, no. 2, pp. 189-192; no. 3 , pp. 275-285; no. 4, pp. $437-440$; no. 5, pp. 529-533; no. 6 , pp. 625629 ; no. 7, pp. 725-728, 1914.

Johnson, B. L.

617. The Port Wells gold-lode district [Alaska]: U. S. Geol. Survey, Bull. 592, pp. 195-236, 1 pl. (map), 1 fg. (sketch map), 1914:

618. Mining on Prince William Sound [Alaska]: U. S. Geol. Survey, Bull. 592, pp. 237-243, 1914.

Johnson, Douglas W.

619. Precise leveling and the problem of coastal subsidence (abstract, with discussion): Geol. Soc. America, Bull., vol. 25, no. 1, pp. 59-60, March 30, 1914.

620. The shoreline of Cascumpeque Harbor, Prince Edward Island (abstract): New York Acad. Sci., Annals, vol. 23,.pp. 261-262, April 30, 1914.

621. Botanical phenomena and the problem of coastal subsidence (abstract): Am. Geog. Soc., Bull., vol. 46, no. 6, p. 432, June, 1914.

Johnson, Douglas W., and Smith, Warren S.

622. Recent storm effects on the northern New Jersey shoreline, and their supposed relation to coastal subsidence: New Jersey Geol. Survey, Bull. 12, pp. 27-44, 3 pls., 4 figs., 1914.

$97921^{\circ}-$ Bull. $617-15-4$ 
Johnston, John, and Adams, L. H.

623. Observations on the Daubrée experiment and capillarity in relation to certain geological speculations: Jour. Geology, vol. 22, no. 1, pp. 1-15, 3 figs., January-February, 1914; (abstract), Washington Acad. Sci., .Jour., vol. 4, no. 1, pp. 5-6, January 4, 1914.

Johnston, Robt. A. $\Lambda$.

624. Mineralogy: Canada Geol. Survey, Summ. Rept., 1912, pp. 411-414, 1914.

625. Mineralogy: Canada Geol. Survey, Summ. Rept., 1913, pp. 327-330, 1914.

Johnston, W. A.

626. Geology of Lake Simcoe area, Ontario; Beaverton, Sutton, and Barrie sheets: Canada Geol. Survey, Summ. Rept., 1912, pp. 294-300, 1914.

627. The calcareous drift and lacustrine deposits in Rainy River district, Ontario: Canäda Geol. Survey, Summ. Rept., 1913, pp. 170-177, 1914.

Johnston, William Caley.

Isthmian earthquakes. See MacDonald and Johnston, no. 789.

Jonas, Anna I.

Relation of the Wissahickon mica gneiss to the Shenandoah limestone and to the Octoraro mica schist, of the Doe Run-Avondale district, Coatesville quadrangle, Pennsylvania. See Bliss and Jonas, no. 101.

Jones, Charles Colcock.

The discovery and opening of a new phosphate field in the United States: Am. Inst. Min. Eng., Trans., vol. 47, pp. 192-216, 13 figs., 1914. See no. 569 of the bibliography for 1913, U. S. Geol. Survey, Bull. 584.

Jones, Daniel J.

The geology and mineralogy of Hardwick and Woodbury, Vermont. See Richardson, Brainerd, and Jones, no. 997.

Jones, E. L., jr.

Economic geology of the region around Mullan, Idaho, and Saltese, Montana. See Calkins and Jones, no. 192.

Jones, J. Claude.

628. The tufa deposits of the Salton Sink: Carnegie Inst. Washington, Pub. no. 193 (MacDougal, The Salton Sea), pp. 79-83, 1914.

629. The geologic history of Lake Lahontan [Nevada]: Science, new ser., vol, 40, pp. 827-830, December 4, 1914.

630. Occurrence of stibnite and metastibnite at Steamboat Springs, Nevada (abstract): Geol. Soc. America, Bull., vol. 25, no. 1, p. 126, March 30, 1914.

Jones, Olive M.

631. Bibliography of Colorado geology and mining, with subject index, from the earliest explorations to 1912: Colorado Geol. Survey, Bull. 7, 493 pp., 1914.

Jones, S. C.

632. Soil surveys: Kentucky Geol. Survey, Fourth Series, vol. 1, pp. 1067-1156, 1913.

Jones, William F.

633. Coal-bearing Eocene of western Washington; Pierce County (abstract): Geol. Soc. America, Bull., vol. 25, no. 1, pp. 121-122, March 30, 1914.

Joralemon, Ira B:

634. The Ajo copper mining district [Arizona]: Am. Inst. Min. Eng., Bull., no 92, pp. 2011-2028, 3 figs., August, 1914; Eng. and Min. Jour., vol. 98, no. 15, pp. 663-665, map, October 10, 1914. 
Juday, Chancey.

The inland lakes of Wisconsin. See Birge and Juday, no. 91.

Julien, Alexis A.

635. The genesis of antigorite and talc: New York Acad. Sci., Annals, vol. 24, pp. 23-38, 1 pl., July 25, 1914.

Katz, Frank J.

636. Feldspar: U. S. Geol. Survey, Mineral Resources, 1913, pt. 2, pp. 145-151, 1914.

637: Silica (quartz); abrasive materials: U. S. Geol. Survey, Mineral Resources, 1913, pt. 2, pp. 175-180, 253-272. 1914.

Recent literature on economic geology. See Paige and Katz, no. 907.

Kay, George F.

638. A new gypsum deposit in Iowa: U. S. Geol. Survey, Bull. 580, pp. 59-64, 1 fig., 1914; (abstract) Science, new ser., vol. 39, p. 404, March 13, 1914.

639. American Association for the Advancement of Science; Section E, Geology and Geography: Science, new ser., vol. 39, pp. 398-405, March 1.3, 1914.

640. Twenty-first annual report of the State geologist: Iowa Geol. Survey, vol. 23, pp. xvii-xlviii, 2 figs., map, 1914.

641. Twenty-second annual report of the State Geologist: Iowa Geol. Survey, Ann. Rept., vol. 24, pp. vii-xvi, 2 maps (in pocket), 1914.

642. Mineral production in Iowa in 1911 and 1912: Iowa Geol. Survey, Ann. Rept., vol. 24 , pp. 1-32, 1914 .

643. Some evidence of recent progress in geology (abstract): Iowa Acad. Sci., Proc., vol. 21, pp. 169-172, 1914.

Keele, J.

644. Clay and shale deposits of New Brunswick: Canada Geol. Survey, Mem. 44, viii, 94 pp., I map (in pocket), 16 pls., 7 figs., 1914:

645. Investigation of clay resources of Quebec: Canada Geol. Survey, Summ. Rept. 1912, pp. 351-356, 1914.

646. Report on progress of investigation of clay resources: Canada Geol. Survey, Summ. Rept. 1913, pp. 288-292, 1914.

Report on the clay and shale deposits of the western provinces (part II). See Ries and Keele, no. 1006.

Keeley, Frank J.

647. Notes on some igneous rocks at Ogunquit, Maine, and Pigeon Cove, Massachusetts: Acad. Nat. Sci. Philadelphia, Proc., vol. 66, pt. 1, pp. 3-8, January, 1914.

Keith, Arthur.

648. A pre-Cambrian uncomformity in Vermont (abstract): Geol. Soc. America, Bull., vol. 25, no. 1, pp. 39-40, March 30, 1914.

Kemp, James $\mathrm{F}$.

649. The influence of depth on the character of metalliferous deposits: Int. Geol. Cong., XII, Canada, 1913, C. R., pp. 253-260, 1914.

650. The newer theories of ore deposition: Min. and Metall: Soc. America, Bull. 79 (vol. 7, no. 12), pp. 188-197, December 31, 1914.

651. New point in the geology of the Adirondacks (abstract, with discussion): Geol. Soc. America, Bull., vol. 25, no. 1, p. 47, March 30, 1914.

652. Secondary silicate zone (discussion): Econ. Geology, vol. 9, no. 3, p. 282, April, 1914.

The ground-waters: Am. Inst. Min. Eng., Trans., vol. 45, pp. 3-25, 1914. See no. 592 of the bibliography for 1913, U. S. Geol. Survey, Bull. 584. 
Kew, William S. W.

653. Tertiary echinoids of the Carrizo Creek region in the Colorado Desert: California, Univ., Dept. Geology, Bull., vol. 8, no: 5, pp. 39-60, 5 pls., 1 fig. (map), April 16, 1914.

654. Echinoderms of the San Pablo (abstract): Geol. Soc. America, Bull., vol. 25, no. 1, p. 152, March 30, 1914.

Keyes, Charles R.

655. Complete succession of Iowan Cretacic terranes: Iowa Acad. Sci., Proc., vol. 20, pp. 199-201, 1913.

Discusses the sequence and correlation of the Cretaceous formations of Iowa.

656. Recognition of beds of Tertiaric age in our state: Iowa Acad. Sci., Proc., vol. 20, p. 203, 1913.

657. Late Devonic sequence of the Iowa region (synopsis): Iowa Acad. Sci., Proc., vol. 20 , pp. 205-206, 1913.

658. Certain features of eolic gradation: Int. Geol. Cong., XII, Canada, 1913, C. R., pp. 941-945, 1914 .

659. Paleogeographical affinities of the Alexandrian series: Am. Jour. Sci., 4th ser., vol. 37,.pp. 254-256, 1 fig., March, 1914.

660. Iowa's great period of mountain making: Iowa Acad. Sci., Proc., vol. 21, pp. 181-187, 1 fig., 1914.

661. Serial subdivision of the early Carbonic succession in the continental interior: Iowa Acad. Sci., Proc., vol. 21, pp. 189-193, 1 pl. (map), 1914.

662. Our pre-Cambrian rocks: Iowa Acad. Sci., Proc., vol. 21, pp. 195-202, 1914.

663. Life and work of Charles Abiathar White: Annals of Iowa, $3 \mathrm{~d}$ ser., vol. 11, no. 7, pp. 497-504, 2 pls. (ports.), October, 1914.

664. Great ice ages in Iowa: Annals of Iowa, $3 \mathrm{~d}$ ser., vol. 11, no. 6, pp. 465-469, July, 1914.

665. Syllabus of a course of lectures on geologic processes and geographic products in arid regions. Revised reprint, $15 \mathrm{pp}$. Socorro, School of Mines Press, 1914.

666. Chart of the geologic terranes of Iowa. $3 \mathrm{pp}$. Des Moines, Robert Henderson, State Printer, 1914.

667. Foundation of modern geologic science in America: Annals of Iowa, 3d ser., vol. 11, no. 6, pp. 401-407, July, 1914.

668. Stratigraphic position of our oldest rocks [Iowa] (abstract): Science, new ser., vol. 40, p. 144, July 24, 1914.

669. Rate of continental denudation: Science, new ser., vol. 40, pp. 933-934, December $25,1914$.

670. Erosive potential of desert waters (abstract): Geol. Soc. America, Bull., vol. 25, no. 1, p. 88, March 30, 1914.

671. Recent backward extension of the life record in geologic time (abstract): Science, new ser., vol. 39, p. 405, March 15, 1914.

672. Siouan Mountains; an Iowan Triassic episode (abstract): Science, new ser., vol. 40, p. 144, July 24, 1914.

673. Serial unit in stratigraphic classification (abstract): Science, new ser., vol. 40, p. 144, July 24, 1914.

Kindle, Edward M.

674. An inquiry into the origin of Batrachioides the antiquor of the Lockport dolomite of New York: Geol. Mag., dec. 6, vol. 1, no. 4, pp. 158-161, 2 pls., April, 1914.

675. Columnar structure in limestone: Canada Geol. Survey, Mus. Bull. no. 2, pp. 35-39, 2 pls., June 17, 1914.

676. The Silurian and Devonian section of western Manitoba: Canada Geol, Survey, Summ. Rept., 1912, pp. 247-261, 1914. 
Kindle, Edward M.-Continued.

677. Notes on the. Oriskany sandstone and the Ohio shale of the Ontario Peninsula: Canada Geol. Survey, Summ. Rept. 1912, pp. 286-290, 1 fig., 1914.

678. Report of the invertebrate paleontologist: Canada Geol. Survey, Summ. Rept. 1912, pp. 404-406, 1914.

679. Report of the invertebrate paleontologist: Canada Geol. Survey, Summ. Rept. 1913, pp. 300-314, 1914.

680. What does the Medina sandstone of the Niagara section include?: Science, new ser., vol. 39, pp. 915-918, June 19, 1914.

681. A comparison of the Cambrian and Ordovician ripple-marks found at Ottawa, Canada: Jour. Geology, vol. 22; no. 7, pp. 703-713, 6 figs., OctoberNovember, 1914.

Kirk, Charles T.

682. The geology of the Gallup Basin, New Mexico: New Mexico, Univ., Bull. no. 76 (Geol. Ser., vol. 3, no. 2), pp. 28-68, 1 pl. (map and sections), June, 1914.

Kirk, Edwin.

683. Notes on the fossil crinoid genus Homocrinus Hall: U. S. Nat. Mus., Proc., vol. 46, pp. 473-483, 1 pl., February 14, 1914.

Knight, Cyril W.

The pre-Cambrian geology of southeastern Ontario, with an appendix on the correlation of the pre-Cambrian.rocks of Ontario, western Quebec, and southeastern Manitoba. See Miller and Knight, no. 848.

Knight, Nicholas.

684. Unusual dolomites: Iowa Acad. Sci., Proc., vol. 21, pp. 127-128, 1914.

Knopf, Adolph.

685. Economic geology in 1913: Eng. and Min. Jour., vol. 97, no. 2, pp. 112-114, January 10, 1914.

686. Mineral resources of the Inyo and White Mountains, California: U. S. Geol. Survey, Bull. 540, pp. 81-120, 3 figs. (incl. map), 1914.

687. The Darwin silver-lead mining district, California; U. S. Geol. Survey, Bull. 580, pp. 1-18, 3 figs., 1914.

688. Is the Boulder batholith a laccolith? (discussion): Econ. Geology, vol. 9, no. 4, pp. 396-402, June, 1914.

689. A platinum-gold lode deposit in southern Nevada (abstract): Min. and Sci. Press, vol. 109, no. 26, p. 990, December 26, 1914.

Knowlton, Frank Hall.

690. The Jurassic flora of Cape Lisburne, Alaska: U. S. Geol. Survey, Prof. Paper 85-D, pp. 39-55, 4 pls., 1914; (abstract) Washington Acad. Sci., Jour., vol. 4, no. 7, p. 165, April 4, 1914.

691. Cretaceous-Tertiary boúndary in the Rocky Mountain region: Geol. Soc. America, Bull., vol. 25, no. 3, pp. 325-340, September 15, 1914; (abstract) Science, new ser., vol. 39 , p. 843, June 5, 1914.

692. Fossil forests of the Yellowstone National Park: U. S. Dept. of the Interior, Office of the Secretary, 31 pp., 15 figs., map, 1914.

693. A forest of stone [Gallatin Mountains, Montana]: Am. Forestry, vol. 20, no. 10, pp. 709-718, 9 figs., October, 1.914.

Knox, George.

694. Mining subsidence: Int. Geol. Cong., XII, Canada, 1913, C. R., pp. 797-806, 15 figs., 1914. 
Kraus, Edward H.

695. Composition of bornite and its relation to other sulphominerals (abstract, with discussion): Geol. Soc. America, Bull., vol. 25, no. 1, pp. 90-91, March 30, 1914.

Kraus, E. H., and Goldsberry, J. P.

696. The chemical composition of bornite and its relation to other sulphominerals: Am. Jour. Sci., 4th ser., vol. 37, pp. 539-553, 1 fig., June, 1914; Neues Jahrb, Bd. 2, H. 3, pp. 127-144, 1 fig., December 31, 1914.

Krebs, Charles E., and Teets, D. D., jr.

697. Kanawha County [West Virginia]: West Virginia Geol. Survey, 679 pp., 3 maps (under separate cover), 33 pls., 14 figs., 1914.

Describes the physiographic features, the geologic structure, the occurrence, character, and relations of Carboniferous strata, and the petroleum, natural gas, coal, and other economic resources.

Krusch, P.

698. Primäre und sekundäre Erze unter besonderer Berücksichtigung der "gel" und der "schwermetallreichen" Erze: Int. Geol. Cong., XII, Canada, 1913, C. R., pp. 275-286, 1914.

\section{Kümmel, Henry B.}

699. Annual administrative report of the State geologist for the year 1913: New Jersey Geol. Survey, Bull. 12, pp. 7-25, 1914.

Description of the Raritan quadrangle, New Jersey. See Bayley, Salisbury, and Kümmel, no. 66 .

Geologic map of New Jersey. Geologic map of New Jersey, scale 1:250,000. See Lewis and Kümmel, no. 747.

Kunz, George Frederick.

700. The geology of the Hudson River and its relation to bridges and tunnels: Am. Scenic and Historic Preservation Soc., 18th Ann. Rept., pp. 401$454,1913$.

Lahee, Frederic H.

701. Field and office methods in the preparation of geologic reports; misuse of the term "eruptive": Econ. Geology, vol. 9, no. 1, pp. 72-73, January, 1914.

702. Late Paleozoic glaciation in the Boston Basin, Massachusetts: Am. Jour. Sci., 4th ser., vol. 37, pp. 316-318, April, 1914.

703. Crystalloblastic order and mineral development in metamorphism: Jour. Geology, vol. 22, no. 5, pp. 500-515, 21 figs., July-August, 1914.

704. Contemporaneous deformation; a criterion for aqueo-glacial sedimentation: Jour. Geology, vol. 22, no. 8, pp. 786-790, 3 figs., November-December, 1914.

Iamb, G. F.

705. Middle Mississippian unconformities and conglomerates in northern Ohio: Ohio Naturalist, vol. 14, no. 8, pp. 344-346, June, 1914.

\section{Lambe, Lawrence M.}

706. On the fore limb of a carnivorous dinosaur from the Belly River formation of Alberta, and a new genus of Ceratopsia from the same horizon, with remarks on the integument of some Cretaceous herbivorous dinosaurs: Ottawa Naturalist, vol. 27, no. 10, pp. 129-135, 5 pls., January, 1914.

707. On Gryposaurus notabilis, a new. genus and species of trachodont dinosaur from the Belly River formation of Alberta, with a description of the skull of Chasmosaurus belli: Ottawa Naturalist, vol. 27, no. 11, pp. 145-155, 3 pls., February, 1914. 
Lambe, Lawrence M.-Continued.

708. On a new genus and species of carnivorous dinosaur from the Belly River formation of Alberta, with a description of Stephanosaurus marginatus from the same horizon: Ottawa Naturalist, vol. 28, no. 1, pp. 13-20, 1 pl., April, 1914.

709. On new species of Aspideretes from the Belly River formation of Alberta, with further information regarding the structure of the carapace of Boremys pulchra: Roy. Soc. Canada, Trans., 3d ser., vol. 8, pp. 11-16, 1 pl., 1 fig., June, 1914.

710. Description of a new species of Platysomus from the neighborhood of Banff. Alberta: Roy. Soc. Canada, Trans., vol. 8; pp. 17-23, 1 fig., June; 1914.

711. Contributions to Canadian paleontology: Canadian Rec. Sci., vol. 9, no. 6, pp. 383-386, 1914.

712. Report of the vertebrate paleontologist: Canada Geol. Survey, Summ. Rept. 1912, pp. 397-403, 2 pls., 1914.

713. Report of the vertebrate paleontologist: Canada Geol. Survey, Summ. Rept. 1913, pp. 293-299, 1914.

\section{Landes, Henry.}

714. The mineral resources of Washington: Washington Geol. Survey, Bull. no. 11, 53 pp., map., 1914.

Lane, Alfred C.

715. Mine water composition an index to the course of ore-bearing currents: Econ. Geology, vol. 9, no. 3, pp. 239-263, 1 pl., 3 figs., April, 1914. . Tufts Coll. Studies, vol. 4, no. 1, pp. 239-263, October 30, 1914.

716. Effusive and intrusive in the quantitative classification (abstract): Geol. Soc. America, Bull., vol. 25, no. 1, pp. 43-44, March 30, 1914.

Larsen, Esper S.

Contributions to the stratigraphy of southwestern Colorado. See Cross and Larsen, no. 290.

The stratigraphic break below the Jurassic sandstone in southwestern Colorado (abstract). See Cross and Larsen, no. 291.

Custerit, ein neues kontaktmetamorphes Mineral. See Umpleby, Schaller, and Larsen, no. 1214.

Larsen, Esper S., and Hicks, W. B.

717. Searlesite, a new mineral [San Bernardino Co., Cal.]: Am. Jour. Sci., 4th ser., vol. 38, pp. 437-440, November, 1914; Washington Acad. Sci., Jour., vol. 4, no. 14, pp. 397-398, August 19, 1914.

Larsen, E. S., and Hunter, J. F.

718. Melilite and other minerals from Gunnison County, Colorado: Washington Acad. Sci., Jour., vol. 4, no. 16, pp. 473-479, October 4, 1914.

Larsen, E. S., and Schaller, W. T:

719. Cebollite, a new mineral: Washington Acad. Sci., Jour., vol. 4, no. 16, pp. 480-482, October 4, 1914.

Lawson, Andrew C.

720. Report on the geology and the underground water supply of Livermore Valley [California]: pp. 223-230 in The future water supply of San Francisco; a report... by the Spring Valley Water Company, San Francisco, California, 1912.

721. The Archaean geology of Rainy Lake restudied: Canada Geol. Survey, Mem. 40, 115 pp., 9 pls., 1 fig., map (in pocket), 1913. 
-wwson, Andrew C.-Continued.

722. Is the Boulder "batholith" a laccolith? - a problem in ore genesis: California, Univ., Dept. Geology, Bull., vol. 8, no. 1, pp. 1-15, January 8, 1914.

Discusses the genesis of copper ores at Butte, Mont.

723. A standard scale for the pre-Cambrian rocks of North America: Int. Geol. Cong., XII, Canada, 1913, C. R., pp. 349-370, 1914.

724. Description of the San Francisco district; Tamalpais, San Francisco, Concord, San Mateo, and Haywards quadrangles: U. S. Geol. Survey, Geol. Atlas U. S., San Francisco folio (no. 193), 24 pp., 4 figs. (maps), 14 maps, sections and illustrations sheets, 1914; Field edition, 180 pp., 10 pls., 4 figs., 14 maps, section sheet, 1914.

725. Ore deposition in and near intrusive rocks by meteoric waters: California, Univ., Dept. Geology, Bull., vol. 8, no. 9, pp. 219-242, 4 figs., October 3, 1914; Min. and Sci. Press, vol. 109, no. 16, pp. 600-605, October 17, 1914.

726. Diffusion of ore deposits: Min. and Sci. Press, vol. 109, no. 1, pp. 20-21, July 4, 1914.

Lee, Wallace.

727. The geology of the Rolla quadrangle: Missouri Bur. Geology and Mines, 2d ser., vol. 12, xii, 111 pp., 10 pls., 17 figs., 2 maps (in pocket), [1914].

Lee, W. T.

728. Use of physiography in the study of Rocky Mountain stratigraphy (abstract):

Washington Acad. Sci., Jour., vol. 4, no. 1, pp. 8-9, Jånuary 4, 1914.

Lees, James H:

729. Earth movements and drainage lines in Iowa: Iowa Acad. Sci., Proc., vol. 21, pp. 173-180, 1 pl., 1 fig., 1914; (abstract), Science, new ser., vol. 40, p. 144, July 24, 1914.

Leighton, Morris M.

730. Additional evidences of post-Kansan glaciation in Johnson County, Iowa: Iowa Acad. Sci., Proc., vol. 20, pp. 251-256, 1 fig. (map), 2 pls., 1913.

Leith, Charles Kenneth.

731. Relations of the plane of unconformity at the base of the Cambrian to terrestrial deposition in late pre-Cambrian time: Int. Geol. Cong., XII, Canada, 1.913, C. R., pp. 335-337, 1914.

732. Pre-Cambrian correlation from a Lake Superior standpoint: Int. Geol. Cong., XII, Canada, 1913, C. R., pp. 409-421, 1914.

733. Notes on conservation of Lake Superior iron ores: Am. Inst. Min. Eng.; Bull. no. 86, pp. 247-250, 1 fig., February, 1914.

734. Recrystallization of limestone at igneous contacts: Econ. Geology, vol. 9, no. 3, pp. 292-299, A pril, 1914; Am. Inst. Min. Eng., Bull. no. 90, pp. 11291134, June, 1914; Trans., vol. 48, pp. 209-215, 1.915.

Lenher, Victor.

735. On the deposition of gold in nature: Econ. Geology, vol. 9, no. 6, pp. 523528, September, 1914.

Leonard, A. G.

736. Administrative report: North Dakota Geol. Survey, 6th Bienn. Rept., pp. 15-18, 1912.

737. The geology of south central North Dakota: North Dakota Geol. Survey, 6th Bienn. Rept., pp. 21-99, 9 pls. (incl. geol. map), 1912. 
LeRoy, O. E.

738. Mother Lode and Sunset mines, Boundary district, British Columbia: Canada Geol. Survey, Mem. 19, 56 pp., 2 maps (in pocket), 5 pls., 3 figs., 1913.

Lesher, C. E.

739. The Eden Ridge coal field, Coos County, Oregon: U. S. Geol. Survey, Bull. 541, pp. 399-418, 1 fig.; I pl., map, 1914.

The use of thickness contours in the valuation of lenticular coal beds. See Rogers and Lesher, no. 1015.

Leverett, Frank.

740. The Pleistocene [of Minnesota with special reference to clay]: Minnesota Geol. Survey, Bull. no. 11, pp. 30-32, 1914.

741. Map of the surface formations of Minnesota. Sheet 1 [northwest quarter of State]. Scale 1:500,000. Minnesota. Geol. Survey, 1.914.

742. Observations on Craighton Lake [Ohio]: Am. Jour. Sci., 4th ser., vol. 38, pp• 432-436, I fig. (map), November, 1914.

743. Notes concerning the features of St. Joseph Island, Lake Huron, Ontario: Canada Geol. Survey, Summ. Rept., 19]2, pp. 271-274, 1. fig. (map), 1914.

744. Earth-movements in the Minnesota portion of the Lake Agassiz Basin during and since the lake occupancy (abstract, with discussion): Geol. Soc. America;. Bull., vol. 25, no. 1, pp. 34-35, March 30, 1914.

745. Problems of the glacial geologist (abstract): Washington Acad. Sci., Jour., vol. 4, no. 7, pp. 171-172, April 4, 1914.

Lewis, J. Volney.

746. Origin of pillow lavas: Geol. Sọc. America, Bull., vol. 25, no. 4, pp. 591-654, 11 pls., 2 figs., December, 1914; (abstract, with discussion) Geol. Soc. America, Bull., vol. 25, no. 1, pp. 32-33, March 30, 1914.

Lewis, J. Volney, and Kümmel, Henry B.

747. Geologic map of New Jersey, scale 1:250,000. New Jersey Geol. Survey [1914].

\section{Lewis, Robert S.}

748. The Book Cliffs coal field, Utah: Am. Inst. Min. Eng., Bull. no. 91, pp. 1729-1749, 9 figs., July, 1914.

\section{Lindeman, E.}

749. Magnetite occurrences near Calabogie, Renfrew County, Ontario: Canada, Dept. Mines, Mines Branch, 16 pp., 5 maps, 1. fig. (geol. map), 1.914.

750. Moose Mountain iron-bearing district, Ontario: Canada, Dept. Mines, Mines Branch, 14 pp., 2 figs., 8 maps (in map envelope), 1914.

751. Iron ore occurrences in Cape Breton: Canada, Dept. Mines, Mines Branch, Summ. Rept., 1913, pp. 31-36, 1914.

Lindgren, Waldemar.

752. The origin of the "garnet zones" and associated ore deposits: Econ. Geology, vol. 9, no. 3, pp. 283-292, April, 1914; Am. Inst. Min. Eng., Bull. no. 90, pp. 949-956, June, 1914; Trans., vol. 48, pp. 201-208, 1.91 .5$.

Lindgren, Waldemar, and Bancroft, Howland.

753. The Republic mining district, Washington: U. S. Geol. Surrey, Bull. 550; pp. 1.33-166, 9 pls. (incl. map), 3 figs., 1914.

Lizdgren, W., and Whitehead, W. L.

754. A deposit of jamesonite near Zimapan, Mexico: Econ. Geology, vol. 9, no. 5, pp. 435-462, 12 figs., July, 1914. 
Lindsley, Thayer.

755. Economic effect on certain ore deposits of changes in depth: Eng. and Min. Jour., vol. 97, no. 21, pp. 1043-1046, May 23, 1914.

Linforth, Frank A.

756. Dip chart (discussion): Am. Inst. Min. Eng., Bull. no. 96, pp. 2823-2824, 1 fig., December, 1914.

Applied geology in the Butte mines: Am. Inst. Min. Eng., Trans., vol. 46, pp. 110-122, 6 figs., 1914. See no. 700 of the bibliography for 1913, U. S. Geol. Survey, Bull. 584.

Livingston, D. C., and Stewart, C. A.

757. The geology and ore deposits of the Dixie mining district, Idaho: Idaho, Univ., Bull., vol. 9, no. 2, 11 pp., 1 map, March, 1914.

Lloyd, E. Russell.

758. The Cannonball River lignite field, Morton, Adams, and Hettinger counties; North Dakota; U. S. Geol. Survey, Bull. 541, pp. 243-291, 1 fig., 2 maps, 1914.

759. The Cannonball marine member of the Lance formation (abstract): Washington Acad. Sci., Jour., vol. 4, no. 7, pp. 172-173, April 4, 1914.

Recent literature on economic geology. See Paige and Lloyd, no. 908.

Logan, William Newton.

760. The soils of Mississippi: Mississippi Agr. Exper. Sta., Tech. Bull. no. 4, 49 pp., 1 map, 1913.

Loomis, Frederic B.

761. Restoration of some Pyrotherium mammals (anstract, with discussion): Geol. Soc. America, Bull., vol. 25, no. 1, pp. 139-140, March 30, 1914.

762. Analysis of the Pyrotherium fauna (abstract, with discussion): Geol. Soc. America, Bull., vol. 25, no. 1, p. 140, March 30, 1914.

Louderback, George D.

763. Proceedings of the fourteenth annual meeting of the Cordilleran section of the Geological Society of America, held at Berkeley, California, April 11 and 12, 1913: Geol. Soc. America, Bull., vol. 25, no. 1, pp. 119-126, March 30, 1914.

Loughlin, G. F.

764. A reconnaissance in the Canyon Range, west-central Utah: U. S. Geol. Survey, Prof. Paper 90, pp. 51-60, 1 pl., 5 figs. (incl. map), 1914.

765. The oxidized zinc ores of the Tintic district, Utah: Econ. Geology, vol. 9, no. 1, pp. 1-19, 2 pls., 8 figs., January, 1914.

766. Utah, California, and Idaho [stone industry]: U. S. Geol. Survey, Mineral Resources, 1913, pt. 2, pp. 1346-1366, 1376-1387, 1914.

Loughlin, G. F., and Hechinger, L. A.

767. An unconformity in the Narragansett Basin of Rhode Island and Massachusetts: Am. Jour. Sci., 4th ser., vol. 38, pp. 45-64, 1 fig. (map), July, 1914.

Lowe, E. N.

768. Preliminary report on iron ores of Mississippi: Mississippi State Geol. Survey, Bull. no. 10, 70 pp., 7 figs. [1914].

Lull, Richard Swann.

769. Rulers of the Mesozoic: Yale Rev., new ser., vol. 3, pp. 352-363, January, 1914. 
Iull, Richard Swann-Continued.

770. Elephants and their progenitors; the story of the evolution of the elephants or Proboscidea from their earliest recorded ancestor, the Mœris beast: Science Conspectus, vol. 4, no. 3, pp. 61-70, 2 pls., 8 figs., 1914.

771. Fossil dolphin from California: Am. Jour. Sci., 4th ser., vol. 37 , pp. 209-220, 1 pl, 7 figs., March, 1914.

772. New mastodon find in Connecticut (abstract): Geol. Soc. America, Bull., vol. 25, no. 1., p. 143, March 30, 1914.

See also Schuchert, C., no. 1052.

Lupton, Charles T.

773. Oil and gas near Green River, Grand County, Utah: U. S. Geol. Survey, Bull. 541, pp. 115-133, 1 fig., map, 1914.

774. Oil and gas in the western part of the Olympic Peninsula, Washington: U. S. Geol. Survey, Bull. 581, pp. 23-81, 2 maps, 1914.

Luther, D. D.

775. Geology of the Attica-Depew quadrangles: New York State Mus., Bull. 172, 34 pp., 1 map (in pocket), 1914.

McCaskey, H. D.

776. Gold, silver, copper, lead, and zinc in the Eastern States in 1913: U. S. Geol. Survey, Mineral Resources, 1913, pt. 1, pp. 173-196, 1914.

777. Quicksilver: U. S. Geol. Survey, Mineral Resources, 1913, pt. 1, pp. 197$212,1914$.

778. Gold and silver (general report): U. S. Geol. Survey, Mineral Resources, 1913, pt. 1, pp. 845-885, 1914.

Copper ores of the New London mine [Frederick County, Maryland]. See Butler and McCaskey, no. 176.

McConnell, R. G.

779. Texada Island, British Columbia: Canada Geol. Survey, Mem. 58, 112 pp., 5 maps (in pocket), 12 pls., 1 fig., 1914.

780. Portions of Portland Canal and Skeena mining divisions, Skeena District, British Columbia: Canada Geol. Survey, Mem. 32, 101 pp., 7 pls., 3 figs., 2 maps (in pocket), 1913.

781. Geological section along the Grand Trunk Pacific railway from Prince Rupert to Aldermere, British Columbia: Canada Geol. Survey, Summ. Rept. 1912; pp. 55-62, 1914.

782. Princess Royal Island, British Columbia: Canada Geol. Survey, Summ. Rept. 1912, pp. 63-67, 1 fig., 1914.

783. Texada Island, British Columbia: Canada Geol. Survey, Summ. Rept. 1912, p. 68, 1914.

784. Rainy Hollow mineral area, British Columbia: Canada Geol. Survey, Summ. Rept. 1913, pp. 29-33, map, 1914.

785. Recent development at the Hidden Creek mine, Observatory Inlet, British Columbia: Canada Geol. Survey, Summ. Rept. 1913, pp. 55-57, 1 diagram, 1914.

786. Britannia mine, Howe Sound, British Columbia: Canada Geol. Survey, Summ. Rept. 1913, pp. 76-79, 1914.

MacDonald, Donald F.

787. Excavation deformations: Int. Geol. Cong., XII, Canada, 1913, C. R., pp. 779-792, 4 figs., 1914.

788. Report of the physiography and general geology of the lower flood plain of the Sixaola River and the hills at and near Punta Mona: Costa RicaPanama Arbitration, Appendix No. 2 to the counter case of Costa Rica, pp. 73-111, pls. (incl. maps), Washington, Press of Gibson Bros. inc., 1914. 
MacDonald, Donald F., and Johnston, William Caley.

789. Isthmian earthquakes: Canal Record, vol. 7, pp. 144-149, 2 maps, December 10, 1913.

Gives an account of the physiographic features and geology of Los Santos, Panama.

McDonald, P. B.

790. Kaolin mining operations in the South: Min. and Eng. World, vol. 40, no. 6, pp. 281-282, 3 figs., February 7, 1914.

McDougal, D. T., and others.

791. The Salton Sea; a study of the geography, the geology, the floristics, and the ecology of a desert basin: Carnegie Inst. Washington, Pub. no. 193, 182 pp., 32 pls., 4 figs., 1914.

MacKenzie, John D.

792. South Fork coal area, Oldman River, Alberta: Canada Geol. Survey, Summ. Rept. 1912, pp. 235-246, 2 maps, 1914.

793. South central Graham Island, British Columbia: Canada Geol. Survey; Summ. Rept. 1913, pp. 34-54, 1914.

794. The Crowsnest volcanics: Canada Geol. Survey, Mus. Bull. no. 4, 33 pp., 1 pl., 1 fig. (map), November 19, 1914.

- Maclaren, Malcolm.

795. The persistence of ore. in depth: Int. Geol. Cong., XII, Canada, 1913, C. R., pp. 295-304, 2 figs., 1914; Min. and Sci. Press, vol. 108, no. 14, pp. 566567, April 4, 1914.

MacLean, A., and Wallace, R. C.

796. Gypsum and salt in Manitoba: Canada Geol. Survey, Summ. Rept. 1913, pp. 165-169, 1914.

MacLean, T. A.

797. Lode mining in Yukon; an investigation of quartz deposits in the Klondike division: Canada, Dept. Mines, Mines Branch, 205 pp., 40 pls., 35 figs., 6 maps, 1914.

Maddren, A. G.

798. Mineral deposits of the Yakataga district, Alaska: U. S. Geol. Survey, Bull. 592 , pp. 119-153, 1 pl. (map), 1914.

799. Quaternary history of the Mount St. Elias region, Alaska (abstract): Washington Acad. Sci., Jour., vol. 4, no. 1, pp. 10-11, January 4, 1914.

Mailhiot, A.

800. Granites of the eastern townships of Quebec:' Canada Geol. Survey, Summ. Rept. 1913, pp. 217-218, 1914.

Malcolm, Wyatt.

801. Notes on radium-bearing minerals: Canada Geol. Survey, Prospector's Handbook, no. 1, 26 pp., 1914.

Malloch, G. S.

802. The Groundhog coal field, British Columbia: Canada Geol. Survey, Summ. Rept., 1912, pp. 69-101, map, 1914.

803. Metalliferous deposits in the vicinity of Hazelton, British Columbia: Canada Geol. Survey, Summ. Rept. 1912, pp. 102-1.07, 1914.

Manchester, James G.

804. The minerals of Broadway, New York City: New York Mineralog. Club, Bull. no. 3, 52 pp., 2 pls., 19 figs., May, 1914. 
Mann, K. L.

805. Secondary eurichment in gold veins: Min. Sci., vol. 70, pp. 22-23, December, 1914.

Mansfleld, G. R.

Geology of the phosphate deposits northeast of Georgetown, Idaho. Seo Richards and Mansfield, no. 995.

Margerie, Emm. de.

806. The geological map of the world: Int. Geol. Cong., XII, Canada, 1913, C. R., pp. 173-187, 1914.

Martin, Bruce.

807. Descriptions of new species of fossil Mollusca from the later marine Neocene of California: California, Univ., Dept. Geology, Bull., vol. 8, no. 7, pp. 181-202, 4 pls., Aug. 6, 1914.

Neocene record in the Temblor Basin, California, and Neocene deposits of the San Juan district, San Luis Obispo County, California. See Anderson and Martin, no. 18.

Martin, G. C., and Mertie, J. B., jr.

808. Mineral resources of the upper Matanuska and Nelchina valleys: U. S. Geol. Survey, Bull. 592, pp. 273-299, 1 pl. (map), 1914.

Martin, Lawrence.

809. The physical geography of Wisconsin: Jour. Geog., vol. 12, no. 8, pp. 226232, 1 fig., April, 1914.

810. Submarine topography in Glacier Bay, Alaska (abstract): Geol. Soc. America, Bull., vol. 25, no. 1, pp. 88-89, March 30, 1914.

Alaskan glacier studies of the National Geographic Society in the Yakutat Bay, Prince.William Sound, and lower Copper River regions. See Tarr and Martin, no. 1157.

College physiography. See Tarr and Martin, no. 1158.

Matthes, F. E.

811. Studying the Yosemite problem: Sierra Club Bull., vol. 9, no. 3, pp. 136-147, January, 1914.

812. Mount Rainier and its glaciers, Mount Rainier National Park. 48 pp., 24 figs., 1 map. U. S., Department of the Interior, Washington, D. C., Government Printing Office, 1914.

813. The glaciers of Mount Rainier [Washington]: Am. Forestry, vol. 20, no. 9, pp. 646-667, 18 figs., September, 1914.

814. Concave exfoliation (abstract): Washington Acad. Sci., Jour., vol. 4, no. 11, p. 295, June 4, 1914.

815. Moraine Dome and the moraines of the Little Yosemite Valley (abstract): Washington Acad. Sci., Jour., vol. 4, no. 11, pp. 295-296, June 4, 1914.

Matthew, G. F.

816. The physics of the Cambrian formation in eastern Canada and the peculiarities of its faunas: Roy. Soc. Canada, Trans., 3d ser., vol. 8, sec. 4, pp. 69-85, September, 1914.

Matthew, W. D.

817. Time ratios in the evolution of mammalian phyla; a contribution to the problem of the age of the earth: Science, new ser., vol. 40, pp. 232-235, August 14, 1914.

818. Evolution of the horse in nature: Am. Mus. Nat. Hist., Guide Leaflet ser. no. 36, pp. 1-35, 61-63, 23 figs., 2 pls., September, 1913. 
Matthew, W. D.-Continued.

819. Evidence of the Paleocene vertebrate fauna on the Cretaceous-Tertiary problem: Geol. Soc. America, Bull., vol. 25, no. 3, pp. 381-402, 3 figs., September 15, 1914.

820. New discoveries in the American Eocene (abstract): British Assoc. Adv. Sci., Rept. 83d meeting, Birmingham, 1913, p. 491; 1914.

821. Report of progress in the revision of the Lower Eocene faunas (abstract): Geol. Soc. America, Bull., vol. 25, no. 1, pp. 144-145, March 30, 1914.

822. Notes on Cuban fossil mammals (abstract): New York Acad. Sci., Annals, vol. 23, p. 263, April 30, 1914.

823. A Zalambdodont Insectivore from the basal Eocene of New Mexico (abstract): New York Acad. Sci., Annals, vol. 23, pp. 263-264, April 30, 1914. See also Johannsen, no. 615.

Maynard, T. Poole.

824. The Tennessee phosphates (abstract): Science, new ser., vol. 39, p. 401, March 13, 1914.

825. The green slates of Georgia (abstract): Tennessee Acad. Sci., Trans., vol. 1, p. 68, August 1, 1914.

Mead, W. J.

826. The average igneous rock: Jour. Geology, vol. 22 , no. 8, pp. 772-781, 4 figs., November-December, 1914.

Means, A. H.

827. Tourmaline-bearing gold quartz veins of the Michipicoten district, Ontario: Econ. Geology, vol. 9, no. 2, pp. 122-135, 6 figs., March, 1914.

Mehl, M. G.

Western extension of some Paleozoic faunas in southeastern Missouri (abstract). See Weller and Mehl, no. 1271.

Meinzer, O. E.

828. Ground water for irrigation on the Great Plains: U. S. Geol. Survey, WaterSupply Paper 345, pp. 21-23, 1914.

829. The water resources of Butte, Montana: U. S. Geol. Survey, Water-Supply Paper 345, pp. 79-125, 3 pls. (incl, map), 4 figs., 1914.

Merriam, John C.

830. The Brea maid: Southern California Acad. Sci., Bull., vol. 13, no. 2, pp. 27-29, 1 fig., July, 1914.

Discusses the occurrence and age of human remains in asphalt at Rancho La Brea, California.

831. Preliminary report on the discovery of human remains in an asphalt deposit at Rancho La Brea [California]: Science, new ser., vol. 40, pp. 198-203, August 7, 1914.

832. Correlation between the Tertiary of the Great Basin and that of the marginal marine province in California: Science, new ser., vol. 40, pp. 643-645, October 30, 1914.

833. The occurrence of Tertiary mammalian remains in northeastern Nevada: California, Univ., Dept. Geology, Bull., vol. 8, no. 12, pp. 275-281, 3 figs., December 10, 1914.

834. Vertebrate fauna of the Orindan and Siestan formations (abstract): Geol. Soc. America, Bull., vol. 25, no. 1, p. 156, March 30, 1914.

Merrill, Frederick J. H.

835. Geology and mineral resources of San Diego and Imperial counties [California]: California State Min. Bur., 113 pp., illus., December, 1914. 
Merrill, George P.

836. The Meteor Crater of Arizona: Australasian Assoc. Adv. Sci., Rept. Twelfth Meet., Brisbane, 1909, pp. 320-323, 4 figs., 1910.

Merritt, John Wesley.

837. Sedimentary character of garnetiferous hornblende schist, Hanover, New Hampshire (abstract): Geol. Soc. America, Bull., vol. 25, no. 1, p. 75, March 30, 1914.

Mertie, J. B., jr.

Mineral resources of the upper Matanuska and Nelchina valleys. See Martin and Mertie, no. 808 .

Merwin, H. E.

838. The optical properties of azurite and alamosite: Washington Acad. Sci., Jour., vol. 4, no. 10, pp. 253-254, May 19, 1914.

839. The simultaneous crystallization of calcite and certain sulphides of iron, copper, and zinc; a crystallographic study: Am. Jour. Sci., 4th ser., vol. 38, pp. 355-359, 2 figs., October, 1914.

Hewettite, metahewettite, and pascoite, hydrous calcium vanadates. See Hillebrand, Merwin, and Wright, no. 541.

Meunier, Stanislas.

840. Origin and mode of formation of magmatic gases: Washington Acad. Sci., Jour., vol. 4, no. 9, pp. 213-218, May 4, 1914.

Michelson, A. A.

841. Preliminary results of measurements of the rigidity of the earth: Jour. Geology, vol. 22, no. 2, pp. 97-130, 16 figs., February-March, 1914.

Mickle, G. R.

842. The chemical composition of natural gas found in Ontario: Ontario, Bur. Mines, Ann. Rept., vol. 23, pt. 1, pp. 237-273, 5 maps, 2 figs., 1914.

Miller, Arthur M.

843. Geology of the Georgetown quadrangle: Kentucky Geol. Survey, Fourth Series, vol. 1, pp. 317-351, 10 pls., 5 figs., 1913.

844. Evolution by selection of mutations: Science, new ser., vol. 40, pp. 636-637, October 30, 1914.

Miller, Benjamin L.

845. Analysis of the report of the geologist appointed by the Commission of Engineers of the Costa Rica-Panama Boundary Arbitration: Costa RicaPanama Arbitration, Appendix No. 2 to the counter case of Costa Rica, pp. 3-70, Washington, Press of Gibson Bros. inc., 1914.

Miller, Loye Holmes.

846. Bird remains from the Pleistocene of San Pedro, California: California, Univ,, Dept. Geology, Bull., vol. 8, no. 4, pp. 31-38, April 16, 1914.

Miller, Willet G.

847. The pre-Cambrian rocks north of Lake Huron (prefatory note): Ontario, Bur. Mines, Ann. Rept., vol. 23, pt. 1, pp. 202-203, 1914.

Miller, Willet G., and Knight, Cyril W.

848. The pre-Cambrian geology of southeastern Ontario, with an appendix on the correlation of the pre-Cambrian rocks of Ontario, western Quebec, and southeastern Manitoba: Ontario, Bur. Mines, Rept., vol. 22, pt. 2, 151 pp., 67 figs., 13 maps, 1914. 
Miller, William J.

849. The geological history of Now York State: New York State Mus., Bull. 168, 130 pp., 53 pls., 40 figs., 1914.

850. Geology of the North Creek quadrangle, Warren County, New York: New York State Mus.; Bull. 170, 90 pp., 14 pls., 10 figs., 1 map (in pocket), February 15, 1914.

851. Magmatic differentiation and assimilation in the Adirondack region: Geol. Soc. America, Bull., vol. 25, no. 2, pp. 243-264, June 29, 1914; (abstract, with discussion), Geol. Soc. America, Bull., vol. 25, no. 1, pp. 45-46, March 30, 1914.

Millis, John.

852. What was the cause of the eskers?: Science, new ser., vol. 39, no. 997, pp. 208-209, February 6, 1914.

Miser, Hugh D.

853. New areas of diamond-bearing peridotite in Arkansas: U. S. Geol. Survey, Bull. 540, pp. 534-546, 1 pl., 3 figs., 1914.

Mofflt, Fred H.

854. Geology of the Hanagita-Bremner region, Alaska: U. S. Geol. Survey, Bull. 576, 56 pp., 2 maps (in pocket), 4 pls., 6 figs., 1914.

855. Preliminary report on the Broad Pass region: U. S. Geol. Survey, Bull. 592, pp. 301-305, 1 pl. (sketch map), 1914.

856. Mining in the Valdez Creek placer district: U. S.:Geol. Survey, Bull. 592, pp. 307-308, 1914.

Moodie, Roy L.

857. The fossil frogs of North America: Am. Jour. Sci., 4th ser., vol. 38, pp. 531536, 2 figs., December, 1914.

Mook, Charles C.

858. Notes on Camarasaurus Cope: New York Acad. Sci., Annals, vol. 24, pp. 19-22, 1 fig., May 21, 1914; (abstract), Geol. Soc. America, Bull., vol. 25, no 1, p. 143, March 30, 1914.

859. The dorsal vertebræ of Camarasaurus Cope: Am. Mus. Nat. Hist., Bull., vol. 33, pp. 223-227, 3 figs., 1914.

Moore, Charles J.

The London mine, Mosquito mining district, Park County, Colorado: Am. Inst. Min. Eng., Trans., vol. 45, pp. 239-250, 9 figs. (sections), 1914. See no. 834 of the bibliography for 1913, U. S. Geol. Survey, Bull. 584.

Moore, Elwood S.

860. Region east of the south end of Lake Winnipeg [Manitoba]: Canada Geol. Survey, Summ. Rept. 1912, pp. 262-270, map, 1914.

861. The excursions of the International Geological Congress: Penn State Min. Quart., vol. 1, no. 2, pp. 68-81, 6 figs., April, 1914.

862. Oolitic and pisolitic barite from the Saratoga oil field, Texas: Geol. Soc. America, Bull., vol. 25, no. 1, pp. 77-79, 6 figs., March 30, 1914.

863. Mud cracks open under water: Am. Jour. Sci., 4th ser., vol. 38, pp. 101-102, July, 1914.

864. Hydrothermal alteration of granite: Econ. Geology, vol. 9, no. 4, pp. 392-395, June, 1914.

Morganroth, L. C.

865. The occurrence, preparation, and use of magnesite: Am. Inst. Min. Eng., Bull., no. 93, pp. 2345-2352, 4 figs., September, 1914. 
Morse, Edward S.

866. An avalanche of rocks [Mount Desert Island, Maine]: Science, new ser., vol. 40, p. 241, August 14, 1914.

Morse, William Clifford, and Foerste, August F.

867. Preliminary report on the Waverlian formations of east central Kentucky and their economic values: Kentucky Geol. Survey, Bull. no.16, 76 pp., 5 figs., 1912.

Muilenburg, Garrett A.

868. On the occurrence of precious stones in the drift [of Iowa]: Iowa Acad. Sci., Proc., vol. 21, pp. 203-204, 1914.

Munn, Malcolm J.

869. Reconnaissance of the Grandfield district, Oklahoma: U. S. Geol. Survey, Bull. 547, 83 pp., 5 pls. (incl. maps), 1914; (abstract by C. H. Wegemann): Washington Acad. Sci., Jour., vol. 4, no. 14, pp. 419-421, August $19,1914$.

870. Reconnaissance of oil and gas fields in Wayne and McCreary counties, Kentucky: U. S. Geol. Suryey, Bull. 579, 105 pp., 6 pls., 6 figs., 1914.

Napper, Charles W.

871. Flood erosion along Paint Creek, Fayette County, Ohio: Ohio Naturalist, vol. 14, no. 4, pp. 252-255, 4 figs., February, 1914.

Nason, Frank L.

872. The disseminated lead district of southeast Missouri (discussion): Eng. and Min. Jour., vol. 97, no. 23, pp. 1158-1159, June 6, 1914.

Neuman, L. M.

A study of the effects of heat on Missouri granites. See Tarr and Neuman, no. 1160.

Newcombe, C. F.

873. Pleistocene raised beaches at Victoria, British Columbia: Ottawa Naturalist, vol. 28 , no. 8, pp. 107-110, 1 map, 2 figs., November, 1914.

Newland, D.H.

874. The mining and quarry industry of New York State: report of operations and production during 1913: New York State Mus., Bull. 174, 111 pp., 1914,

Nichols, Rriph.

Lead-silver mines of Gilmore, Lemhi County, Idaho: Am. Inst. Min. Eng., Trans., vol. 46, pp. 937-939, 1 fig., 1914. See no. 846 of the bibliography for 1913, U. S. Geol. Survey, Bull. 584.

Nicholson, H. H.

875. Oil and gas fields of north Texas: Min. Sci., vol. 69, pp. 34-37, May, 1914.

Nickles; John M.

876. Bibliography of North American geology for 1913, with subject index: U. S. Geol. Survey, Bull. 584, 183 pp., 1914.

Nishihara, George S.

877. Importance of carbonates in the rôle of secondary enrichment: Econ. Geology, vol. 9, no. 5, pp. 483-485, July, 1914.

878. Manganese as an impurity in some of the sulphides: Econ. Geology, vol. 9, no. 5 , p. 485, July, 1914.

878. The rate of reduction of acidity of descending waters by certain ore and gangue minerals and its bearing upon secondary sulphide enrichment: Econ. Geology, vol. 9, no. 8, pp. 743-757, 2 figs., December, 1914.

$97921^{\circ}-$ Bull. $617-15-5$ 
Noble, L. F.

880. The Shinumo quadrangle, Grand Canyon district, Arizona: U. S. Geol. Survey, Bull. 549, 100 pp., 18 pls. (incl. map in pocket), 1 fig., 1914.

North, Frederick J.

881. On the genus Syringothyris Winchell: Geol. Mag., dec. 5, vol. 10, no. 9, pp. 393-401, 1 pl., September, 1913.

Notman, Arthur.

882. Geology of the Bisbee ore deposits [Arizona]: Inst. Min. and Met., London, Trans., vol. 22, pp. 550-562, 3 figs., 1913.

O'Connell, Marjorie.

883. Revision of the genus Zaphrentis: New York Acad. Sci., Annals, vol. 23, pp. 177-192, February 25, 1914.

884. Description of some new Siluric gastropods: Buffalo Soc. Nat. Sci., Bull., vol. 11, no. 1, pp. 93-101, 1 pl., 3 figs., 1914.

Ogilvie, Alan G.

885. Les variations périodiques des glaciers, 19i3; Glaciers of the Canadian Rockies and Selkirk Mountains: Zeitschr. Gletscherkunde; Bd. 9, H. 1, pp. 60-61, December, 1914.

Oklahoma Geological Survey.

886. Structural map of the Cushing oil field. [1914.]

Oldroyd, T. S. .

887. A remarkably rich pocket of fossil drift from the Pleistocene: Nautilus, vol. 28, no. 7, pp. 80-82, November, 1914.

Olsson, Axel.

888. Notes on Miocene correlation: Nautilus, vol. 27, no. 9, pp. 101-103, 1 pl., January, 1914.

889. New and interesting Neocene fossils from the Atlantic Coastal Plain: Bull. Am. Paleont., no. 24, 24 pp., 5 pls., December 7, 1914.

O'Neal, Frank E.

890. The Smoky River coal field [Alberta]: Colliery Engineer, vol. 34, no. 6, pp. 346-347, January, 1914.

891. Coal fields of Jasper Park, Alberta: Colliery Engineer, vol. 34, no. 7, pp. 399-402, 7 figs., February, 1914.

O'Neill, J. J.

892. St. Hilaire (Beloeil) and Rougemont mountains, Quebec: Canada Geol. Survey, Mem. 13, 108 pp., map, 1914.

\section{Ontario, Bureau of Mines.}

Twenty-third annual report of the Bureau of Mines, 1914. See Gibson, no. 456 .

Ordóñez, Ezequiel.

893. The oil fields of Mexico: Am. Inst. Min. Eng., Bull., no. 94, pp. 2530-2535, October, 1914; Min. and Eng. World, vol. 41, no. 22, pp. 999-1000, November 28, 1914.

\section{Osborn, Henry Fairfield.}

894. Joseph Leidy, 1823-1891: Nat. Acad. Sci., Biog. Mem., vol. 7, pp. 335-396, port., 1913.

895. Close of the Cretaceous and opening of Eocene time in North America: Geol. Soc. America, Bull., vol. 25, no. 3, pp. 321-323, September 15, 1914.

896. Recent results in the phylogeny of the titanotheres: Geol. Soc. America, Bụll., vol. 25, no. 3, pp. 403-405, 1 fig., September 15, 1914, 
Osborn, Henry Fairfield-Continued.

897. New methods of restoring Eotitanops and Brontotherium: Geol. Soc. America, Bull., vol. 25, no. 3, p. 406, 1 fig., September 15, 1914.

898. Restoration of the world series of elephants and mastodons: Geol. Soc. America, Bull., vol. 25, no. 3, pp. 407-410, 2 figs., September 15, 1914.

899. Rectigradations and allometrons in relation to the conceptions of the "mutations of Waagen," of species, genera, and phyla: Geol. Soc. America, Bull., vol. 25, no. 3, pp. 411-416, 3 figs. (tables), September 15, 1914.

900. Final results in the phylogeny of the titanotheres (abstract, with discussion): Geol. Soc. America, Bull., vol. 25, no. 1, p. 139, March 30, 1914.

Pack, Robert W.

901. Ornamental marble near Barstow, California: U. S. Geol. Survey, Bull. 540, pp. 363-368, 1914.

902. Reconnaissance of the Barstow-Kramer region, California: U. S. Geol. Survey, Bull. 541, pp. 141-154, map, 1914. .

Pack, Robert W., and English, Walter A.

903. Geology and oil prospects in Waltham, Priest, Bitterwater, and Peachtree valleys, California: U. S. Geol. Survey, Bull. 581, pp. 119-160, 1 pl. (map), 4 figs., 1914.

Packard, Earle.

904. Some west coast Mactridæ (abstract): Geol. Soc. America, Bull., vol. 25, no. 1, pp. 151-152, March 30, 1914.

Paige, Sidney.

905. Field and office methods in the preparation of geologic reports; some principles underlying geologic mapping: Econ. Geology, vol. 9, no. 2, pp. 184-189, 3 figs., March, 1914.

906. The mechanics of granite intrusion in the Black Hills, South Dakota (abstract): Washington Acad. Sci., Jour., vol. 4, no. 7, p. 173, April 4, 1914.

Paige, Sidney, and Katz, F. J.

907. Recent literature on economic geology: Econ. Geology, vol. 9, no. 5, pp. 494-502, July; no. 7, pp. 690-701, October, 1914.

Paige, Sidney, and Iloyd, E. Russell.

908: Recent literature on economic geology: Econ. Geology, vol. 9, no. 1, pp. 82-97, January, 1914.

Palache, C.

909. Supplementary note on the crystal form of hodgkinsonite: Washington Acad. Sci., Jour., vol. 4, no. 7, pp. 153-154, April 4, 1914.

Palache, C., and Graham, R. P. D.

910. Über die Krystallisation des Willemits: Zeitschr. Kryst. Min., Bd. 53, H. 4, pp. 332-336, 1 pl., 1914.

Palache, C., and Schaller, W. T.

911. Hodgkinsonit, ein neues Mineral von Franklin, New Jersey: Zeitschr. Kryst. Min., Bd. 53, H. 6, pp. 529-532 and 675-676, 4 figs., 1914.

Palmer, Chase.

912. Mineralogy of waters from artesian wells at Charleston, South Caroiina: U. S. Geol. Survey, Prof. Paper 90, pp. 90-94, 1914.

813. Studies in silver enrichment; tetranickel-triarsenide, its capacity as silver precipitant: Econ. Geology, vol. 9, no. 7, pp. 664-674, October, 1914.

914. Genesis of glauconite (abstract): Geol. Soc. America, Bull., vol. 25, no.1, p. 91 , March 30, 1914 . 
Palmer, Chase, and Bastin, Edson S.

The rôle of certain metallic minerals in precipitating silver and gold: Am. Inst. Min. Eng., Trans., vol. 45, pp. 224-238, 1914. See no. 877 of the bibliography for 1913, U. S. Geol. Survey, Bull. 584.

Palmer, Leroy A.

915. Ore occurrence at the Cloverdale mine [Sonoma County, California]: Min. and Sci. Press, vol. 108, no. 20, p. 812, 1 fig., May 16, 1914.

916. Western Montana coal fields: Colliery Engineer, vol. 34, no. 12, pp. 721-724, 4 figs., July; 1914.

917. Eastern Montana coal fields: Colliery Engineer, vol. 35, no. 1, pp. 19-22, 2 figs., August, 1914.

Pardee, J. T., and Hewett, D. F.

918. Geology and mineral resources of the Sumpter quadrangle, Oregon: Oregon Bur. Mines and Geology, Mineral Resources of Oregon, vol. 1, no. 6, pp. 3-128, 13 pls., 9 figs., map, October, 1914.

Parks, H. M.

919. Preliminary report on building stone in Oregon: Oregon Bur. Mines and Geol, Mineral Resources of Oregon, vol. 1, no. 2, pp. 10-46, 21 figs., 2 maps and sections, February, 1914.

Parks, William A.

920. Report on the building and ornamental stones of Canada; vol. 2, Maritime provinces: Canada, Dept. of Mines, Mines Branch, 264 pp., 45 pls., 9 figs., 1914.

921. Report on the building and ornamental stones of Canada; vol. 3, Province of Quebec: Canada, Dept. of Mines, Mines Branch, 304 pp., 52 pls., 12 figs., 1914.

Parsons, Charles L.

922. Our radium resources: Am. Min. Cong., Rept. 16th Ann. Sess., 1913, pp. 223234, 1914.

923. Fuller's earth: U. S. Bur. Mines, Bull. 71, 36 pp., 1913.

Paulcke, W.

924. Über tektonische Experimente: Int. Geol. Cong., XII, Canada, 1913, C. R., pp. 835-841, 1914.

Payne, Henry M.

925. Coal mining in Yukon Territory: Colliery Engineer, vol. 35, no. 3, pp. 133135, 4 figs., October, 1914.

Peattie, Roderick.

926. Topography of the bedrock under Chicago; with discussion: Western Soc. Eng., Jour., vol. 19, no. 6, pp. 590-611, 1 map, 3 figs., June, 1914.

\section{Pennsylvania Topographic and Geologic Survey Commission.}

927. Biennial report of the topographic and geologic survey of Pennsylvania for the two years ending June 1, 1914. 232 pp., 5 pls. (maps). Harrisburg, 1914.

Penrose, R. A. F., jr.

928. Certain phases of superficial diffusion in ore deposits: Econ. Geology, vol. 9, no. 1, pp. 20-24, January, 1914.

Peralta, Ricardo Fernández.

929. Ascensión al volcán de Miravalles [Costa Rica]: Costa Rica, Ministerio de Fomento, Bol., año 4, no. 3, pp. 160-171, 8 figs., March, 1914.

Gives data on the volcano Miravalles, Costa Rica. 
Perisho, Ellwood Chappell.

930. Report of the State geologist for 1913-1914: South Dakota Geol. Survey, Bull. no. 6, pp. 107-115, 1914.

Perkins, George H.

931. Report of the State geologist on the mineral industries and geology of Vermont, 1913-1914. Ninth of this series. 448 pp., 78 pls. (incl. maps), 41 figs. Burlington, Vt., 1914 .

The various papers have been listed under the individual authors.

932. History of the Vermont marble industry: Vermont, State Geologist, Ninth Rept., pp. 161-223, 24 pls., 1914.

933. Mineral resources: Vermont, State Geologist, Ninth Rept., pp. 430-439, 1 pl: (map), 1914.

Perret, Frank A.

934. The diagrammatic representation of volcanic phenomena: Am. Jour. Sci,, 4th ser., vol. 37 , pp. 48-56, 4 pls., January, 1914.

See also Hawaiian Volcano Observatory, no. 518.

Peterson, O. A.

935. A new titanothere from the Uinta Eocene: Carnegie Mus., Annals, vol. 9, nos. 1-2, pp. 29-52, 5 pls., 14 figs., September, 1914.

936. A small titanothere from the lower Uinta beds: Carnegie Mus., Annals, vol. 9, nos. 1-2, pp. 53-57, 1 pl., 2 figs., September, 1914.

937. A mounted skeleton of Platigonus leptorhinus in the Carnegie Museum: Carnegie Mus., Annals, vol. 9, nos. 1-2, pp. 11.4-117, 1 pl., September, 1914.

938. Correction of a generic name: Carnegie Mus., Annals, vol. 9, nos. 1-2, p. 220, September, 1914.

Substitutes Diploceras for Eotitanotherium.

939. Some undescribed remains of the Uinta titanothere Dolichorhinus: Carnegie Mus., Annals, vol. 9, nos. 1-2, pp. 129-138, 7 figs., September, 1914.

940. The osteology of Promerycochœrus: Carnegie Mus., Annals, vol. 9, nos. 1-2, pp. 149-21.9, 10 pls., 40 figs., September, 1.914.

The osteology of the Chalicotheroidea. See Holland and Peterson, no. 559.

Peterson, William.

941. Phosphate deposits in the Mississippian rocks of northern Utah: Science, new ser., vol. 40, pp. 755-756, November 20, 1914.

Phalen, W. C.

942. Celestite deposits in California and Arizona: U. S. Geol. Survey, Bull. 540, pp. 521-533, 3 figs., 1914.

943. Bauxite and aluminum: U. S. Geol. Survey, Mineral Resources, 191.3, pt. 1, pp. 1-27, 1 fig., 1914.

944. Sulphur, pyrite, and sulphuric acid: U. S. Geol. Survey, Mineral Resources, 1913 , pt. 2, pp. 23-47, 1914.

945. Potash salts; summary for 1913: U. S. Geol. Survey, Mineral Resources, 1913, pt. 2, pp. 85-107, 1914.

946. Phosphate rock; salt, bromine, and calcium chloride: U. S. Geol. Survey, Mineral Resources, 1913, pt. 2, pp. 273-307, 1914.

947. The bauxite industry in the Southern States (abstract); Science, new ser., vol. 39, pp. 400-401, March 13, 1914.

948. The outlook for the aluminum industry in the South (abstract): Science, new ser., vol. 39, p. 401, March 1.3, 1914.

949. The salt industry of the Southern States (abstract): Science, new ser., vol.o 39, pp. 401-402, March 13, 1914. 
Phillips, William B., and Worrell, S. H.

950. The fuels used in Texas: Texas, Univ., Bull. no. 307 (Scient. Sєr. no. 35), 287 pp., pls., December 22, 1913.

Pickering, William $\mathrm{H}$.

951. The origin of meteorites: Pop. Astron., vol. 17, no. 5, pp. 273-282, May, 1909. 952. The chance of collision with a comet, iron meteorites, and Coon Butte [Ariz.]: Pop. Astron. vol. 17, no. 6, pp. 329-339, June-July, 1909.

Pilsbry, Henry A.

Fresh-water mollusks of the Oligocene of Antigua. See Brown and Pilsbry, no. 132.

Pirsson, L. V.

953. Geology of Bermuda Island; the igneous platform: Am. Jour. Sci., 4th ser., vol. 38, pp. 189-206, 3 figs., September, 1914.

954. Geology of Bermuda Island; petrology of the lavas: Am. Jour. Sci., 4th ser., vol. 38, pp. 331-344, 2 figs., October, 1914.

Pirsson, L. V., and Schuchert, Charles.

955. Note on the occurrence of the Oriskany formation on Parlin Stream, Maine: Am. Jour. Sci., 4th ser., vol. 37, pp. 221-224, March, 1914.

Pirsson, L. V., and Vaughan, T. Wayland.

956. Contributions to the geology of Bermuda (abstract): Science, new ser., vol. 39; p. 568, April 17, 1914.

Pishel, M. A.

Geology of the Standing Rock and Cheyenne River Indian reservations. See Calvert, Beekly, Barnett, and Pishel, no. 193.

Plumb, C. H.

957. The tripoli industry: Eng. and Min. Jour., vol. 96, no. 26, pp. 1285-1287, 2 figs., June 27, 1914.

Powell, S. L.

958. A comparison of the Ordovician section of southwest Virginia, with that of Now York (abstract): Science, new ser., vol. 39, pp. 404-405, March 13, 1914.

Powers, Sidney.

Geology of the Diamond Hill-Cumberland district in Rhode Island-Massachusetts. See Warren and Powers, no. 1256.

Powers, Sidney, and Shimer, Harvey W.

959. Notes on the geology of the Sun River district, Montana: Jour. Geology, vol. 22, no. 6, pp. 556-559, 1 fig., September-October, 1914.

Pratt, Joseph Hyde.

960. The mining industry in North Carolina during 1911 and 1912: North Carolina Geol. and Econ. Survey, Econ. Paper no. 34, 336 pp., 23 pls. (incl. map), 12 figs., 1914.

961. The occurrence and utilization of certain mineral resources of the Southern States: Elisha Mitchell Sci. Soc., Jour., vol. 30, no. 1, pp. 1-25; no. 2, pp. 90-115, 1914.

Price, W. Armstrong.

962. Notes on the paleontology of Kanawha County [West Virginia]: West Virginia Geol. Survey, Kanawha County, pp. 639-655, 2 pls., 1914.

963. Notes on the paleontology of Preston County [West Virginia]: West Virginia Geol. Survey; Preston County, pp. 472-553, 2 pls., 1914. 
Probert, F. R.

964. The Three R mine, Patagonia district, Arizona: Min. and Sci. Press, vol. 109, no. 5, pp. 174-176, 3 figs., August 1, 1914.

Prosser, Warren C.

965. Silver Lake basin, Colorado: Eng. and Min. Jour.. vol. 97, no. 25, pp. 1229-1.231, 3 figs., 1. map, June 20, 1914.

Pulsifer, H. B.

966. New Hampshire mica deposits near Grafton: Min. and Eng. World, vol. 41, no. 4, pp. 141-143, 5 figs., July 25, 1914.

Purdue, A. H.

967. Administrative report of the State geologist, 1914: Tennessee State Geol. Survey, Bull. 18, 17 pp., 1.914.

968. A double waste from hillside wash: Tennessee State Geol. Survey, Resources of Tennessee, vol. 4, no. 1, pp. 36-37, January, 1914.

969. Bauxite in Tennessee: Tennessee State Geol. Survey, Resources of Tennessee, vol. 4, no. 2, pp. 87-92, 2 figs., A pril, 1914.

970. Road materials of Tennessee: Tennessee State Geol. Survey, The Resources of Tennessee, vol. 4, no. 3, pp. 132-1.35, July, 1914.

971. Some neglected principles of physiography (abstract): Tennessee Acad. Sci., Trans., vol. 1., pp. 92-94, August 1, 1914.

972. Zinc mining in Tennessee: Eng. and Min: Jour., vol. 98, no. 10, pp. 419421, 4 figs., map, September 5, 1914.

Rankin, G. A.

Physical-chemical system, lime-alumina-silica and its geological significance (abstract). See Wright and Rankin, no. 1342.

Ransome, F. L.

973. Copper deposits near Superior, Arizona: U. S. Geol, Survey, Bull. 540, pp. 139-158, 9 figs., 1914.

974. Wurtžite at Goldfield, Nevada: Washington Acad. Sci. Jour., vol. 4, no. 16, pp. 482-485, October 4, 1914.

Ray, Frank A.

975. The Ohio coal supply and its exhaustion: Ohio State Univ. Bull., vol. 18, no. 32, 46 pp., maps, seetions, and tables, 1914.

Ray, James C.

976. The reflecting microscope in mining geology and metallurgy: Min. and Sci. Press, vol. 108, no. 23, pp. 922-926, 2 pls., June 6, 1914.

977. Paragenesis of the ore minerals in the Butte district, Montana: Econ. Geology, vol. 9, no. 5, pp. 463-481, 7 pls., July, 1914.

Raymond, Percy E.

978. Notes on the ontogeny of Paradoxides, with the description of a new species from Braintree, Massachusetts: Harvard Coll., Mus. Comp. Zool., Bull., vol. 58, no. 4, pp. 225-244, 1 pl., 3 figs., April, 1914.

979. Notes on the ontogeny of Isotelus gigas Dekay: Harvard Coll., Mus. Comp. Zool., Bull., vol. 58, no. 5, pp. 247-263, 3 pls., 7 figs., April, 1914.

980. The Trenton group in Ontario and Quebec: Canada Geol. Survey, Summ. Rept., 1912, pp. 342-350, 1914.

981. The succession of faunas at Levis, Quebec: Canada Geol. Survey, Summ. Rept. 1913, pp. 219-222, 1914.

982. The succession of faunas at Levis, Province of Quebec: Am. Jour. Sci., 4th ser., vol. 38, pp. 523-530, December, 1914. 
Raymond, Percy E.-Continued.

983. A Beatricea-like organism from the middle Ordovician: Canada Geol. Survey, Mus. Bull. no. 5, 10 pp., 4 pls., November 23, 1914.

984. Report on invertebrate paleontology: Harvard Coll., Mus. Comp. Zool., Ann. Rept. 1913-1914, pp. 40-41, 1914.

Reagan, Albert B.

885. The glacial epoch: Kansas Acad. Sci., Trans., vol. 26, pp. 70-83, 1914.

Reeds, Chester A.

986. Oolites of the Chimneyhill formation, Oklahoma (abstract, with discussion): Geol. Soc. America, Bull., vol. 25, no. 1, pp. 75-76, March 30, 1914.

987. Mounting of rock and fossil specimens with sulphur (abstract): Geol. Soc. America, Bull., vol. 25, no. 1, p. 136, March 30, 1914.

Reger, David B.

Preston County, [West Virginia]. See Hennen and Reger, no. 527.

Reid, Harry Fielding.

888. The influence of earthquake disturbances on suspended magnets: Seismol.

Soc. America, Bull., vol. 4, no. 4, pp. 204-214, December, 1914.

989. Les variations périodiques des glaciers, 1913: Amérique du Nord-États Unis; Zeitschr. Gletscherkunde, Bd. 9, H. 1, pp. 56-59, December, 1914.

990. Earthquake sea waves (abstract, with discussion): Geol. Soc. America, Bull., vol. 25, no. 1, pp. 33-34, March 30, 1914.

Rich, John Lyon.

991. Divergent ice flow on the plateau northeast of the Catskill Mountains as revealed by ice-molded topography: Geol. Soc. America, Bull., vol. 25, no. 1, pp. 68-70, 1 fig., March 30, 1914.

992. Certain types of stream valleys and their meaning: Jour. Geology, vol. 22, no. 5, pp. 469-497, 10 figs., July-August, 1914.

993. The occurrence of unusually large bowlders in gravel deposits [New Mexico]: Am. Jour. Sci., 4th ser., vol. 38, pp. 441-445, 3 figs., November, 1914.

Richards, R. W.

994. Niter near Melrose, Montana: U. S. Geol. Survey, Bull. 540, pp. 470-473, 1 fig., 1914.

Richards, R. W., and Mansfield, G. R.

995. Geology of the phosphate deposits northeast of Georgetown, Idaho: U. S. Geol. Survey, Bull. 577, 76 pp., 14 pls., 3 figs., 1914.

Richardson, Charles H., and Turner, Homer G.

996. The terranes of Greensboro, Vermont: Vermont, State Geologist, Ninth Rept., pp. 277-293, 5 pls. (incl. map), 1914.

Richardson, Charles H., Brainerd, Arthur E., and Jones, Daniel J.

997. The geology and mineralogy of Hardwick and Woodbury, Vermont: Vermont, State Geologist, Ninth Rept., pp. 294-336, 17 pls. (incl. map), 1.914.

Richardson, G. B.

998. Petroleum near Dayton, New Mexico: U. S. Geol. Survey, Bull. 541, pp. 135-140, 1 fig. (map), 1914.

999. Description of the Van Horn quadrangle, Texas: U. S. Geol. Survey, Geol. Atlas U. S., Van Horn folio (no. 194), 9 pp., 5 figs., 3 maps, illustration sheet, 1914.

Rickard, T. A.

1000. Persistence of ore in depth: Inst. Min. and Metal., Bull. no. 122, 44 pp., 3 pls., 8 figs., 1914; (discussion), Bull. no. 123, pp. 3-9, 1914. 
Ries, Heinrich.

1001. Clay and shale deposits of the western provinces, Canada; Part III: Canada Geol. Survey, Mem. 47, 73 pp., 11 pls., 8 figs., 1914.

1002. The occurrence of aluminum hydrates in clays: Econ. Geology, vol. 9, no. 4, pp. 402-404, June, 1914.

1003. Clay investigations in western Canada: Canada Geol. Survey, Summ. Rept. 1912, pp. 229-233, 1914.

1004. Clays of British Columbia and Alberta: Canada Geol. Survey, Summ. Rept. 1913, pp. 284-287, 1914.

1005. Clay and shale deposits of the western provinces of Canada: Canadian Min. Inst., Trans., vol. 16, pp. 528-537, 1913.

Fire-clay deposits of Canada: Am. Inst. Min. Eng., Trans., vol. 45, pp. 123-136, 3 figs. (incl. map), 1914. See no. 981 of the bibliography for 1913, U. S. Geol. Survey, Bull. 584.

Ries, Heinrich, and Keele, Joseph.

1006. Report on the clay and shale deposits of the western provinces (Part III): Canada Geol. Survey, Mem. no. 25, 105 pp., 40 pls., 6 figs., 1.91.3.

Ries, Heinrich, and Watson, Thomas $\mathrm{L}$.

1007. Engineering geology. xxvi, 672 pp., 104 pls., 225 figs. New York, John Wiley \& Sons, 1914.

Robertson, William Fleet.

1008. Report of the [British Columbia] Bureau of Mines: British Columbia, Minister of Mines, Ann. Rept. 1913, 459 pp., pls., maps, 1.914.

Robinson, $\mathbf{H}$. $\mathbf{H}$.

1009. The San Franciscan volcanic field, Arizona (abstract by J. F. Hunter): Washington Acad. Sci., Jour., vol. 4, no. 8, pp. 195-196, April 19, 1914.

Rogers, Austin F.

1010. Secondary sulphide enrichment of copper ores with special reference to microscopic study: Min. and Sci. Press, vol. 109, no. 18, pp. 680-686, 12

- figs., October 31, 1914.

1011. Nomenclature of minerals (abstract): Geol. Soc. America, Bull., vol. 25, no. 1, pp. 124-125, March 30, 1914.

Wilkeite, a new mineral of the apatite group, and okenite, its alteration product, from Southem California. See Eakle and Rogers, no. 379.

A geologic and miscroscopic study of a magmatic copper sulphide deposit in Plumas County, California, and its modification by ascending secondary enrichment. See Turner and Rogers, no. 1188.

Rogers, G. Sherburne.

1012. Geology and coal resources of the area southwest of Custer, Yellowstone, and Bighorn counties, Montana: U. S. Geol. Survey, Bull. 541, pp. 31.6-328, 1 fig., map, 1914.

1013. The phosphate deposits of South Carolina: U. S. Geol. Survey, Bull. 580, pp. 183-220, 1 pl. (map), 2 figs. (map and sections), 1914.

1014. The occurrence and genesis of a persistent parting in a coal bed of the Lance formation: Am. Jour. Sci., 4th ser., vol. 37, pp. 299-304, 1 fig., April, 1914.

Rogers, G. S., and Lesher, C. E.

1015. The use of thickness contours in the valuation of lenticular coal beds: Econ. Geology, vol. 9, no. 8, pp. 707-729, 3 pls., December, 1914. 
Rose, Bruce.

1016. Savona map area, British Columbia: Canada Geol. Survey, Summ. Rept. 1912, pp. 151-155, 1914.

1017. Willowbunch coal area, Saskatchewan: Canada Geol. Survey, Summ. Rept.。 1913, pp. 153-164, map, 1914.

\section{Roundy, P. V.}

1018. Original color markings of two species of Carboniferous gastropods: Am. Jour. Sci., 4th ser., vol. 38, pp. 446-450, 1 pl., November, 1914.

\section{Ruedemann, R.}

1019. An alternative explanation of the origin of the Saratoga mineral waters (abstract, with discussion): Geol. Soc. America, Bull., vol. 25, no. 1, p. 38, March 30, 1914.

Geology of Saratoga Springs and vicinity. See Cushing and Ruedemann, no. 296.

St. Clair, Stuart.

1020. Titaniferous iron-ore deposits: Penn State Min. Quart., vol. 1, no. 3, pp. 112-118, June, 1914.

1021. Origin of the Sudbury ore deposits: Min. and Sci. Press, vol. 109, no. 7, pp. 243-246, 2 figs., August 15, 1914.

Salazar .Salinas, Leopoldo.

1022. La industria minera de Mexico, no. 6 [tomo 2, pt. 2]; Estado de Michoacan, segunda parte, pp. 85-112, pls. and maps, Mexico, 1913.

An account of the mining industry, including notes on the geology, of the State of Michoacan, Mexico. For the first part see Grothe and Salazar, no. 501.

La industria minera de Mexiso, no. 5 [tomo 2, pt. 1]. See Grothe and Salazar, no. 501.

Sales, Reno H.

Ore deposits at Butte, Montana: Am. Inst. Min. Eng., Trans., vol. 46, pp. 3-109, 6 pls., 7. figs., 1914. See no. 1001 of the bibliography for 1913, U. S. Geol. Survey, Bull. 584.

Salisbury, Rollin D.

Description of the Raritan quadrangle, New Jersey. See Bayley, Salisbury, and Kümmel, no. 66 .

Introductory geology: See Chamberlin and Salisbury, no. 215.

Salisbury, Rollin D., and Trojwbridge, Arthur C.

1023. The interpretation of tippographic maps; a laboratory manual for use in connection with the topographic maps of the United States Geological Survey, to accompany beginning courses in physiography. v, $64 \mathrm{pp}$. New York, Henry Holt and Company, 1913.

1024. Laboratory exercises in "structural and historical geology; a laborator $;$ manual based on folios of the United States Geological Survey, for us: with classes in structural and historical geology. v, 76 pp. New York, Henry Holt and Cornpany, 1913.

1025. Studies in geology; a laboratory manual based on topographic maps and folios of the United States Geological Survey, for use with classes in physiographic and Etructural geology. v, 68 pp. New York, Henry Holt and Company, 1913.

Sampson, F. A.

1026. Post-Pliocene shells of Providence and Lupus, Missouri: Nautilus, vol. 28, no. 2, pp. 15-17, June, 1914. 


\section{Sandberg, August.}

1027. Report of a reconnaissance along lower Coppermine River, Canada: Canadian Min. Inst., Trans., vol. 16, pp. 86-99, 3 figs., 1 map, 1913; also in Douglas, George M., Lands forlorn, pp. 277-285, map. New York, G. P. Putnam's Sons, 1914.

Sanford, Samuel.

Analyses of mine and car samples of coal collected in the fiscal years 1911 to 1913. See Fieldner and others, no. 421.

Sanford, Samuel, and Stone, Ralph W.

1028. Useful minerals of the United States: U. S. Geol. Survey, Bull. 585,250 pp., 1914.

Sapper, Karl.

1029. Die Hölle von Masaya [Nicaragua]: Neues Jahrb., Beilage Bd. 39 (Festband Bauer), pp. 415-445, 1 pl., 1914.

Examines historical accounts of the volcano Masaya in Nicaragua and the fluidal lava in the craters.

Sardeson, Frederick W.

1030. Characteristics of a corrosion conglomerate: Geol. Soc. America, Bull., vol. 25, no. 2, pp. 265-276, 1 pl., June 29, 1914; (abstract), Geol. Soc. America, Bull., vol. 25, no. 1, p. 39, March 30, 1914.

Savage, T. E.

1031. The relations of the Alexandrian series in Illinois and Missouri to the Silurian section of Iowa: Am. Jour. Sci., 4th ser., vol. 38, pp. 28-37, July, 1914.

1032. On the conditions under which the vegetable matter of the Illinois coal beds accumulated: Jour. Geology, vol. 22, no. 8, pp. 754-765, NovemberDecember, 1914.

Sawyer, A. H.

1033. Russellville brown iron ore district [Alabama]: Eng. and Min. Jour., vol. 98, no. 2, pp. 49-50, 3 figs., June 11., 1914.

Sayles, Robert W.

1034. The Squantum tillite [Massachusetts]: Harvard Coll., Mus. Comp. Zool., Bull., vol. 66, no. 2 (Geol. ser., vol. 10), pp. 141-175, 12 pls., January, 1914.

1035. Report on the geological collection: Harvard Coll., Mus. Comp. Zool., Ann. Rept. 1913-1914, p. 42, 1914.

Schaller, Waldemar $\mathrm{T}$.

1036. The identity of empressite with muthmannite: Washington Acad. Sci., Jour., vol. 4, no. 17, pp. 497-499, October 19, 1914.

1037. Mineralogical notes, Series 3: Washington $\Lambda$ cad. Sci., Jour., vol. 4, no. 13, pp. 354-356, July 19, 1914.

Colorado ferberite and the wolframite series. See Hess and Schaller, no. 530.

Pintadoite and uvanite, two new vanadium minerals from Utah. See Hess and Schaller, no. 531.

Cebollite, a new mineral. See Larsen and Schaller, no. 719.

Hodgkinsonit, ein neues Mineral von Franklin, N. J. See Palache and Schaller, no. 911.

Custerit, ein neues kontaktmetamorphes Mineral. See Umpleby, Schaller and Larsen, no. 1214. 
Schnabel, Anton.

1038. Das Salinenwesen der Vereinigten Staaten von Nord-Amerika: Berg- und Hüttenmännisches Jahrbuch, Bd. 61, H. 2, pp. 84-163, Vienna, 1913.

An account of the salt industry in the United States. Includes notes on the occurrence of brines and salt beds.

Schofield, Stuart James.

1039. The geology of East Kootenay, British Columbia, with special reference to the origin of granite in sills. Abstract of thesis, Massachusetts Institute of Technology. 8 pp. [Boston?], 1912.

1040. Reconnaissance in East Kootenay, British Columbia: Canada Geol. Survey, Summ. Rept. 1912, pp. 221-228, map, 1914.

1041. Reconnaissance in East Kootenay, British Columbia: Canada Geol. Survey, Summ. Rept. 1913, pp. 130-138, 1 fig., 1914.

1042. The origin of granite (micropegmatite) in the Purcell sills: Canada Geol., Survey, Mus. Bull. no. 2, pp. 1-32, 1 pl., 4 figs., June 5, 1914.

1043. The pre-Cambrian (Beltian) rocks of southeastern British Columbia and their correlation: Canada Geol. Survey, Mus. Bull. no. 2, pp. 79-91, 1 fig. (map), July $3,1914$.

1044. The origin of the Rocky Mountains; story of the creation of this great mountain system as deciphered from the documentary evidence of the strata themselves: Science Conspectus, vol. 4, no. 5, pp. 122-131, illus., 1914.

Schrader, Frank C.

1045. Alunite in granite: porphyry near Patagonia, Arizona: U. S. Geol. Survey, Bull. 540, pp. 347-350, 1914.

1046. Alunite at Bovard, Nevada: U. S. Geol. Survey, Bull. 540, pp. 351-356, 1914.

1047. Gold placers on Wind and Bighorn rivers, Wyoming: U. S. Geol. Survey, Bull. 580, pp. 127-145, 1 pl. (map), 1 fig., 1914.

1048. The Rochester mining district, Nevada: U. S. Geol. Survey, Bull. 580, pp. 325-372, 1 pl., 4 figs., 1914.

Schuchert, Charlés.

1049. The delimitation of the geologic periods illustrated by the paleogeography of North America: Int. Geol. Cong., XII, Canada, 1913, C. R., pp. 555591, 2 pls., 1914.

1050. Fossilium catalogus; I, Animalia (F. Frech, ed.), Pars 3, Stelleroidea palæozoica. $53 \mathrm{pp}$. Berlin, W. Junk, 1914.

1051. Climates of geologic time: Carnegie Inst. Washington, Pub. no. 192, pp. 265-298, 4 figs. (incl. paleogeographic maps), 1914.

1052. Mammut americanum in Connecticut; with a note on the Farmington specimen, by Richard S. Lull: Am. Jour. Sci., 4th ser., vol. 37, pp. 321-330, 3 figs., April, 1914.

1053. Obituary-Professor Newton Horace Winchell: Am. Jour. Sci., 4th ser., vol. 37 , p. 566, June, 1914.

1054. Medina and Cataract formations of the Siluric of New York and Ontario: Geol. Soc. America, Bull., vol. 25, no. 3, pp. 277-320, 2 pls., 1 fig. (map), September 1, 1914.

1055. Notes on Arctic Paleozoic fossils: Am. Jour. Sci., 4th ser., vol. 38, pp. 467477, November, 1914.

1056. Climates of the past: Yale Rev., new ser., vol. 2, pp. 719-728, July, 1913.

Note on the occurrence of the Oriskany formation on Parlin Stream, Maine. See Pirsson and Schuchert, no. 955.

Schuchert, Charles, and Barrell, Joseph.

1057. A revised geologic time-table for North America: Am. Jour. Sci., 4th ser., vol. 38, pp. 1-27, 2 figs., July, 1914. 
Schultz, Alfred Reginald.

1058. Geology and geography of a portion of Lincoln County, Wyoming: U. S. Geol. Survey, Bull. 543, 141 pp., 11 pls., 8 figs., 1914; (abstract), Washington, Acad. Sci., Jour., vol. 4, no. 13, p. 370, July 19, 1914.

Schwennesen, A. T.

1059. Ground water for irrigation in the vicinity of Enid, Oklahoma: U. S. Geol. Survey, Water-Supply Paper 345, pp. 11-20, 1 map, 1.914.

1060. Ground water for irrigation in the valley of North Fork of Canadian River near Oklahoma City, Oklahoma: U. S. Geol. Survey, Water-Supply Paper 345, pp. 41-51, 1 pl. (map), 1914.

Scott, D. H., and Jeffrey, E. C.

1061. On fossil plants showing structure from the base of the Waverly shale of Kentucky: Royal Soc. London, Philos. Trans., ser. B, vol. 205, pp. 315-373, 13 pls., 5 figs., 1914.

Scott, Irving Day.

1062. The spacing of fracture systems and its influence on the relief of the land: Beiträge zur Geophysik (Gerlands), Bd. 13, H. 3, pp. 163-181; H. 4, pp. 241-260, 2 pls., 12 figs., 1914.

Sederholm, J. J.

1063. Different types of pre-Cambrian unconformities: Int. Geol. Cong., XII, Canada, 1913; C. R., pp. 313-318, 1914.

1064. On regional granitization (or anatexis): Int. Geol. Cong.; XII, Canada, 1913, C. R., pp. 319-324, 1914.

1065. Some proposals concerning the nomenclature of the pre-Cambrian, etc.: Int. Geol. Cong., XII, Canada, 1913, C. R., pp. 381-385, 1914.

Sellards, E. H.

1066. Administrative report: Florida State Geol. Survey, Sixth Ann. Rept., pp. 9-19, 1914.

1067. Mineral industries and resources of Florida: Florida State Geol. Survey, Sixth Ann. Rept., pp. 21-114, map, 20 figs., 1914.

1068. Some Florida lakes and lake basins: Florida State Geol. Survey, Sixth Ann. Rept., pp. 115-159, 13 figs., 1914.

1068. The relation between the Dunnellon formation and the Alachua clays of Florida: Florida State Geol. Survey, Sixth Ann. Rept., pp. 161-162, 1914.

1070. The origin, mining, and preparation of phosphate rock: Am. Inst. Min. Eng., Bull. no. 93, pp. 2379-2395, 3 figs., September, 1914.

1071. The phosphate deposits of the Southern States (abstract): Science, new ser., vol. 39, p. 401, March 13, 1914.

1072. The production of fuller's earth in the Southern States (abstract): Science, new ser., vol. 39, pp. 402-403, March 13, 1914.

1073. The development of some lake beds in Florida (abstract): Science, new ser., vol. 39, p. 404, March 13, 1914.

Shannon, C. W.

1074. Director's biennial report to the governor of Oklahoma, 1914; Mineral resources of Oklahoma and statistics of production from 1901 to 1914: Oklahoma Geol. Survey, Bull. no. 22, 142 pp., 4 pls., 3 figs. (maps), December, 1914.

Shaw, E. W.

1075. Gas from mud lumps at the mouths of the Mississippi: U. S. Geol. Survey, Bull. 541, pp. 19-22, 1914. 
Shaw, E. W.-Continued.

1076. The mud lumps at the mouths of the Mississippi (abstract by A. H. Brooks): Washington Acad. Sci., Jour., vol. 4, no. 9, pp. 221-222, May 4, 1914.

1077. So-called waterlaid loess of the central United States (abstract): Washington Acad. Sci., Jour., vol. 4, no. 11, p. 298, June 4, 1914.

1078. The characteristics of the Mississippi Delta in the light of some observations on Old World deltas (abstract): Washington Acad. Sci., Joui., vol. 4, no. 11, pp. 298-299, June 4, 1914.

1079. The characteristics of the Mississippi Delta in the light of some observations on Old World deltas (abstract): Am. Geog. Soc., Bull., vol. 46, no. 6, pp. 432-433, June, 1914.

Shedd, Solon.

1080. Cement materials and industry in the State of Washington: Washington Geol. Survey, Bull. no. 4, 268 pp., 21 pls., 10 figs., 1913.

Sherzer, W. H.

1081. Geological report on Wayne County: Michigan Geol. and Biol. Survey, Pub. 12 (Geol. Ser. 9), 388 pp. (incl. maps), 22 figs., 1913.

Shideler, W. H.

1082. The upper Richmond beds of the Cincinnati group: Ohio Naturalist, vol. 14, no. 3, pp. 229-235, January, 1914.

Shimer, Hervey Woodburn.

1083. An introduction to the study of fossils. 450 pp., 175 figs. New York, The MacMillán Company, 1914.

1084. Restoration of extinct reptiles: Science Conspectus, vol. 4, no. 4, p. 108, 2 figs., 1914.

Notes on the geology of the Sun River district, Montana. See Powers and Shimer, no. 959 .

Shipton, W. D.

1085. Pleistocene exposures in Cedar Rapids and vicinity; Iowa Acad. Sci., Proc., vol. 21 , pp. 221-224, 1914.

Siebenthal, C. E.

1086. Spring deposits at Sulphur Springs, Arkansas, with microscopic examination by H. E. Merwin: Econ. Geology, vol. 9, no. 8, pp. 758-767, December, 1914.

1087. Zinc; cadmium; lead: U. S. Geol. Survey, Mineral Resources, 1913, pt. 1, pp. 621-671, 709-745, 1914.

Simons, Theodore.

1088. Finding fault with the "faultless faultfinder": Eng. and Min. Jour., vol. 98, nos. 20 and 26, pp. 884-887, 1148-1149, 1914.

1089. Dip chart (discussion): Am. Inst. Min. Eng., Bull. no. 96, pp. 2821-2823, 4 figs., December, 1914.

Simpson, Howard E.

1090. The physiography of the Devils-Stump Lake region, North Dakota: North Dakota Geol. Survey, 6th Bienn. Rept., pp. 101-157, 8 pls. (incl. maps), 1912.

Sinclair, William J.

1091. A revision of the bunodont Artiodactyla of the middle and lower Eocene of North America: Am. Mus. Nat. Hist., Bull., vol. 33, pp. 267-295, 28 figs., 1914.

1092. "Laramie?," Puerco, and Torrejon in the San Juan Basin, New Mexico (abstract): Geol. Soc. America, Bull., vol. 25, no. 1, p. 138, March 30, 1914.. 
Sinclair, William J., and Granger, Walter.

1093. Paleocene deposits of the San Juan Basin, New Mexico: Am. Mus. Nat. Hist., Bull., vol. 33, pp. 297-316, 8 pls., 2 maps, 1914.

Smith, Burnett.

1094. A new locality for Castoroides [Madison County, New York]: Am. Jour. Sci., 4th ser., vol. 38, pp. 463-466, 1 fig., November, 1914.

1095. Notes on the fossils of the Paleozoic formations within the Syracuse quadrangle [New York]: New York State Mus., Bull. 171, pp. 57-63, 1914.

1096. A review of the mammalian remains from the superficial deposits in the vicinity of Onondaga Lake, New York: New York State Mus., Bull. 171, pp. 64-72, 2 pls., 1914.

Smith, Carl D.

1087. Structure of the Fort Smith-Poteau gas field, Arkansas arid Oklahoma: U. S. Geol. Survey, Bull. 541, pp. 23-33, map, 1914.

1098. The Glenn oil and gas pool and vicinity, Oklahoma: U. S. Geol. Survey, . Bull. 541, pp. 34-48, 1 fig., map, 1914.

Smith, Eugene Allen.

1099. Pioneers in Gulf Coastal Plain geology; presidential address: Geol. Soc. America, Bull., vol. 25, no. 1, pp. 157-178, March 30, 1914.

Smith, George Otis.

1100. Thirty-fifth annual report of the Director of the United States Geological Survey to the Secretary of the Interior for the fiscal year ended June 30, 1914. 163 pp., 2 maps. Washington, 1914.

1101. Our mineral reserves; how to make $\Lambda$ merica industrially independent: U. S. Geol. Survey, Bull. 599, 48 pp., 1914.

Smith, James Perrin.

1102. The middle Triassic marine invertebrate faunas of North America: U. S. Geol. Survey, Prof. Paper 83, 254 pp., 99 pls., 1914.

1103. Acceleration of development in fossil Cephalopoda: Leland Stanford Junior Univ. Publications, 30 pp., 15 pls., 6 figs., April 14, 1914.

Smith, John E.

1104. Geology of Chapel Hill and vicinity [North Carolina]: Elisha Mitchell Sci. Soc., Jour., vol. 30, no. 1, pp. 26-32, June, 1914.

1105. Economic geology of Chapel Hill, North Carolina, and vicinity (abstract): Science, new ser., vol. 40, pp. 385-386, September 11, 1914.

Smith, Philip S.

1106. Lode mining in the Ketchikan region, Alaska: U. S. Geol. Survey, Bull. 592 , pp. 75-94, 1914.

\section{Smith, Richard A.}

1107. The Saginaw oil field: Michigan Acad. Sci., 15th Rept., pp. 33-38, 1913.

1108. The occurrence of oil and gas in Michigan: Michigan Geol. and Biol. Survey, Pub. 14 (Geol. ser. 11), 281 pp., 3 pls., 19 figs. (incl. maps), 1914.

1109. Nonmetallic minerals: Michigan Geol. and Biol. Survey, Pub. 16 (Geol. ser. 13), pp. 79--128, 1914.

Smith, R. W., and Zulch, W. G.

1110. Solution of a landslide fault: Eng. and Min. Jour., vol. 97, no. 22, pp. 10901091, 6 figs., May 30, 1914.

Smith, Warren S.

Recent storm effects on the northern New Jersey shore line and their supposed relation to coastal subsidence. See Johnson and Smith, no. 620 . 
Smith, W. S. Tangier.

1111. Some graphic methods for the solution of geologic problems: Econ. Geology, vol. 9, nos. 1 and 2, pp. 25-66, 136-152, 43 figs., 1914.

1112. Polarized skylight and the petrographic microscope (abstract): Geol. Soc. America, Bull., vol. 25, no. 1, p. 120, March 30, 1914.

Snider, L. C.

1113. The geology of east-central Oklahoma with special reference to the occurrence of petroleum and natural gas: Oklahoma Geol. Survey, Bull. no. 17, 25 pp., 2 maps, March, 1914.

1114. The Mississippian rocks of northeastern Oklahoma: Jour. Geology, vol, 22, no. 6, pp. 613-624, 2 figs., September-October, 1914.

Snyder, J. O.

1115. The fishes of the Lahontan drainage system of Nevada and their relation to geology of the region (abstract): Washington Acad. Sci., Jour., vol. 4, no. 11, pp. 299-300, June 4, 1914.

Soper, E. K.

Preliminary report on the clays and shales of Minnesota. See Grout and Soper, no. 502.

Sosman, R. B.

The determination of mineral and rock densities at high temperatures. See Day, Sosman, and Hostetter, no. 330.

Spearman, Chas.

1116. Microscopic characters of the ore deposits and rocks of the Kirkland Lake district, Ontario: Canadian Min. Jour., vol. 35, pp. 329-332, 11 figs., May 15, 1914.

Spencer, J. W.

1117. Interpretations of the anomalies of gravity: Science, new ser., vol. 39, pp. 645-646, May 1, 1914.

1118. Cause of the postglacial deformation of the Ontario region (abstract, with discussion): Geol. Soc. Amèrica, Bull., vol. 25, no. 1, pp. 65-66, March 30,1914 .

Stansfield, John.

1119: On the origin of graphite: Canadian Min. Inst., Trans., vol. 16, pp. 401-411, 1913.

1120. The drift on the island of Montreal [Quebec]: Canada Geol. Survey, Summ. Rept. 1913, pp. 208-210, 1914.

1121. On a new mode of occurrence of scapolite: Am. Jour. Sci., 4th ser., vol. 38 , pp. 37-40, 1 fig., July, 1914.

Stanton, Timothy W.

1122. Boundary between Cretaceous and Tertiary in North America as indicated by stratigraphy and invertebrate faunas: Geol. Soc. America, Bull., vol. 25, no. 3, pp. 341-354, September 15, 1914.

Stauffer, Clinton R.

1123. Stratigraphy of southwestern Ontario: Canada Geöl. Survey, Summ. Rept. 1912, pp. 291-293, 1914.

Stebinger, Eugene.

1124. Titaniferous magnetite beds on the Blackfeet Indian Reservation, Montana: U. S. Geol. Survey, Bull. 540, pp. 329-337, 1 pl. (map), 2 figs., 1914. 
Stebinger, Eugene-Continued.

1125. The Montana group of northwestern Montana: U. S. Geol. Survey, Prof. Paper 90, pp. 61-68, 1 fig., October 14, 1914.

1126. Stratigraphy of the Montana group (Upper Cretaceous) in northwestern Montana and its relation to the Belly River beds and Judith River formation (abstract): Washington Acad. Sci., Jour., vol. 4, no. 13, pp. 383-384, July 19, 1914.

The coal fields of Montana: Am. Inst. Min. Eng., Trans., vol. 46, pp. 889-919, 1 pl., 3 figs., 1914. See no. 1105 of the bibliography for 1913, U. S. Geol. Survey, Bull. 584.

Steiger, George.

The relative abundance of several metallic elements. See Clarke and Steiger, no. 240.

Steinhart, 0.J.

1127. Production and uses of tungsten: Min. and Sci. Press, vol. 109, no. 2, p. 64, July 11, 1914.

Stephenson, Lloyd William.

1128. Cretaceous deposits of the eastern Gulf region and species of Exogyra from the eastern Gulf region and the Carolinas: U. S. Geol. Survey, Prof. Paper 81, 77 pp., 21 pls. (incl. map), 2 figs., 1914.

1129. A deep well at Charleston, South Carolina: U. S. Geol. Survey, Prof. Paper 90, pp. 69-90, 3 figs., 1914.

1130. The Cretaceous-Eocene contact in the Atlantic and Gulf Coastal Plain (abstract): Washington Acad. Sci., Jour., vol. 4, no. 1, pp. 11-12, January 4, 1914.

\section{Sternberg, Charles H.}

1131. Expeditions to the Miocene of Wyoming and the chalk beds of Kansas: Kansas Acad. Sci.; Trans., vol. 25, pp. 45-49, 1 fig., 1913.

Gives notes on the occurrence of vertebrate fossils.

1132. Notes on the fossil vertebrates collected on the Cope expedition to the Judith River and Cow Island beds, Montana, in 1876: Science, new ser., vol. 40, pp. 134-135, June 24, 1914.

\section{Sterrett, Douglas B.}

1133. Some deposits of mica in the United States: U. S. Geol. Survey, Bull, 580, pp. 65-125, 34 figs., 1914.

1134. Mica: U. S. Geol. Survey, Mineral Resources, 1913, pt. 2, pp. 1-9, 1914.

1135. Gems and precious stones: U. S. Geol. Survey, Mineral Resources, 1913, pt. 2, pp. 649-708, 1914.

Stevens, Blamey.

1136. The laws of jointing: Am. Inst. Min. Eng., Bull. no. 79, pp. 1285-1303, 12 figs., July, 1913; Trans., vol. 47, pp. 91-110, 12 figs., 1914.

1137. Nomenclature of faults: Min. Mag., vol. 10, no. 4, pp. 272-274, April, 1914.

1138. Intrusive pressure of mineralizing solutions: Min. Mag., vol. 11, no. 5, pp. 313-314, November, 1914.

\section{Stevenson, J. J.}

1138. Events leading up to the organization of the Geological Society of America: Geol. Soc. America, Bull., vol. 25, no. 1, pp. 15-17, March 30, 1914.

Stewart, C. A.

1140. The origin of secondary silicate zones (discussion): Econ. Geology, vol. 9, no. 3, pp. 278-281, April, 1914.

$97921^{\circ}-$ Bull. 617-15-6 
Stewart, C. A.-Continued.

1141. A study in applied geology: Min. and Sci. Press, vol. 109, no. 9, pp. 330-333, August 29, 1914.

1142. A comparison of the Cœur d'Alene monzonite with other plutonic rocks of Idaho: Jour. Geology, vol. 22, no. 7, pp. 684-688, 1 fig. (map), OctoberNovember, 1914.

The geology and ore deposits of the Dixie mining district, Idaho. See Livingston and Stewart, no. 757.

Stock, Chester.

1143. The systematic position of the mylodont sloths from Rancho La Brea [Califurnia]: Science, new ser., vol. 39, pp. 761-763, May 22, 1914; (abstract, with discussion) Geol. Soc. America, Bull., vol. 25, no. 1, pp. 143-144, March 30, 1914.

1144. Skull and dentition of the mylodont sloths of Rancho La Brea [California]: California Univ., Dept. Geology, Bull., vol. 8, no. 18, pp. 319-334, 6 figs., December 5, 1914.

1145. Hawver Cave; its Pleistocene fauna (abstract): Geol. Soc. America, Bull., vol. 25, no. 1, p. 155, March 30, 1914.

Stone, Ralph W.

1146. Coal on Dan River, North Carolina: North Carolina Geol. and Econ. Survey, Econ. Paper no. 34, pp. 115-149, map, 1914.

1147. Lime; sand and gravel; gypsum: U. S. Geol. Survey, Mineral Resources, 1913, pt. 2, pp. 309-337, 355-372, 1914.

1148. Glacial Lake Missoula (abstract): Geol. Soc. America, Bull., vol. 25, no. 1, p. 87, March 30, 1914.

Useful minerals of the United States. See Sanford and Stone, no. 1028.

Stone, Ralph W., and Bonine, C. A.

1149. The Elliston phosphate field, Montana: U. S. Geol. Survey, Bull. 580, pp. 373-383, 1 pl. (map), 1914.

Stopes, Marie C.

1150. The "Fern Ledges" Carboniferous flora of St. John, New Brunswick: Canada Geol. Survey, Mem. 41, 142 pp., 25 pls., 21 figs., 1914.

Storms, William H.

1151. The eruption of Mount Lassen [California]: Min. and Sci. Press, vol. 109, no. 4, pp. 143-144, 1 fig., July 25, 1914.

Stose, George W.

1152. Phosphate deposits in southwestern Virginia: U. S. Geol. Survey, Bull. 540, pp. 383-396, 3 figs. (incl. map), 1914.

Stroner, R. C.

1153. Occurrence of mammalian remains at Rancho La Brea (abstract): Geol. Soc. America, Bull., vol. 25, no. 1, p. 156, March 30, 1914.

Stuart, Murray.

1154. The relationship of fossil wood to oil: Econ. Geology, vol. 9, no. 6, pp. 594597, September, 1914.

Swartley, Arthur M.

1155. Ore deposits of northeastern Oregon: Oregon Bur. Mines and Geol., Mineral Resources of Oregon, vol. 1, no. 8, 229 pp., 98 illus., December, 1914. 
Taber, Stephen.

1156. Seismic activity in the Atlantic Coastal Plain near Charleston, South Carolina: Seismol. Soc. America, vol. 4, no. 3, pp. 108-160, 3 pls., 3 figs., September, 1914.

Tarr, Ralph Stockman, and Martin, Lawrence.

1157. Alaskan glacier studies of the National Geographic Society in the Yakutat Bay, Prince William Sound, and lower Copper River regions. xi, 498 pp., 184 pls., 72 figs., 9 maps (in pocket). Washington, The National Geographic Society, 1914.

1158. College physiography. 837 pp., 10 pls., 503 figs. New York, The Macmillan Company, 1914.

Tarr, William A.

1159. Tables for the determination of the common minerals and rocks. $18 \mathrm{pp}$. [Columbia, Mo.], 1914.

Tarr, William A., and Neuman, I. M.

1160. A study of the effects of heat on Missouri granites: Missouri, Univ., Bull., vol. 15, no. 27, 64 pp., 8 pls., September, 1914.

Taylor, Frank B.

1161. Time measures in the Niagara gorge and their application to Great Lake history (abstract, with discussion): Geol. Soc. America, Bull., vol. 25, no. 1, pp. 35-36, March 30, 1914.

Taylor, Walter P.

1162. The problem of aquatic adaptation in the Carnivora, as illustrated in the osteology and evolution of the sea-otter: California, Univ., Dept. Geology, Bull., vol., 7, no. 25, pp. 465-495, 15 figs., January 22, 1914.

Teets, D. D., jr.

Kanawha County [West Virginia]. See Krebs and Teets, no. 697.

Tenney, J. B.

1163. Bisbee [Arizona] porphyry deposits: Eng. and Min. Jour., vol. 97, no. 9, pp. $467-468,3$ figs., February $28,1914$.

Thayer, W. N.

1164. A bibliography of Mexican geology, geogriphy, and mining, 1902-1912: Min. Sci., vol. 70, pp. 52-56, August; pp. 53-56, September; 53-58, October, 1914.

Thiessen, Reinhardt.

The origin of coal. See White and Thiessen, no. 1285 .

Thomas, A. O.

1165. A new section of the railway cut near Graf, Iowa: Iowa Acad. Sci., Proc., vol. 21, pp. 225-229, 1914.

Thomas, Ki.by.

1166. The Sudbury nickel district of Ontario: Eng. and Min. Jour., vol. 97, no. 2, . pp. 152-154, map, January 10, 1914.

Thompson, Arthur Perry.

1167. On the relation of pyrrhotite to chalcopyrite and other sulphides: Econ.

Geology, vol. 9, no. 2, pp. 153-174, 20 figs., March, 1914. 
Thompson, James D., jr.

1168. The Locust Grove esker, Ohio: Denison Univ., Sci. Lab., Bull., vol. 17, pp. 395-398, 1 fig. (map), September, 1914.

Thwaites, Fredrik T.

1169. Recent discoveries of "Clinton" iron ore in eastern Wisconsin: U. S. Geol. Survey, Bull. 540, pp. 338-342, 1 fig., 1914.

Tilton, John L.

1170. The proper use of the geological name "Bethany"': Iowa Acad. Sci., Proc., vol. 20 , pp. 207-211, 1913.

Discusses the nomenclature and correlation of Carboniferous beds in Iowa.

1171. A Pleistocene section from Des Moines south to Allerton: Iowa Acad. Sci., Proc., vol. 20, pp. 213-220, 3 pls., 1913.

1172. An area of Wisconsin drift further south in Polk County, Iowa, than hitherto recognized: Iowa Acad. Sci., Proc., vol. 21, pp. 219-220, 1 fig. (map), 1914 (abstract), Science, new ser., vol. 40, p. 145, July 24, 1914.

Todd, J.E.

1173. The Pleistocene history of the Missouri River: Science, new ser., vol. 39, pp. 263-274, map, February 20, 1914.

Tolman, C. F., jr.

1174. Recent advances in the study of sulphide enrichment: Miv. and Sci. Press, vol. 108, no. 4, pp. 172-176, January 24, 1914.

1175. The laboratory study of secondary enrichment: Min. and Sci. Press, vol. 109, no. 17, pp. 649-650, October 24, 1914.

Tolman, C. F., jr., and Clark, John D.

1176. The oxidation, solution, and precipitation of copper in electrolytic solutions and the dispersion and precipitation of copper sulphides from colloidal suspensions, with a geological discussion: Econ. Geology, vol. 9, no. 6, pp. 559-592, 1 pl., 3 figs., September, 1914.

Tomlinson, W. Harold.

1177. Field and office methods in the preparation of geologic reports; commercial petrographic reports: Econ. Geology, vol. 9, no. 1, pp. 67-72, January, 1914.

Tovote, William L.

1178. The Globe mining district, Arizona: Min. and Sci. Press, vol. 108, no. 11, pp. 442-449, 8 figs.; no. 12, pp. 487-492, 4 figs., March 14 and 21, 1914.

Tristán, J. Fidel.

1179. El volcán de Miravalles [Costa Rica]: Costa Rica, Ministerio de Fomento, Bol., año 4, no. 3, pp. 157-160, 2 figs., March, 1914.

Trowbridge, Arthur (.

1180. Preliminary report on geological work in northeastern lowa: Iowa Acad. Sci., Proc., vol. 21, pp. 205-209, 1914.

1181. The formation of eskers: Iowa Acad. Sci., Proc., vol. 21, pp. 211-218, 1914; (abstract), Science, new ser., vol. 40, p. 145, July 24, 1914.

1182. A classification of common sediments and some criteria for identification of the various classes: Jour. Geology, vol. 22, no. 4, pp. 420-436, 12 figs., May-June, 1914.

The interpretation of topographic maps; a laboratory manual for use in connection with the topographic maps of the United States Geological Survey, to accompany beginning courses in physiography. See Salisbury and Trowbridge, no. 1023. 
Trowbridge, Arthur C.-Continued.

Laboratory exercises in structural and historical geology; a laboratory manual based on folios of the United States Geological Survey, for use with classes in structural and historical geology. See Salisbury and Trowbridge, no. 1024.

Studies in geology; a laboratory manual based on topographic maps and folios of the United States Geological Survey, for use with classes in physiographic and structural geology. See Salisbury and Trowbridge, no. 1025.

Troxell, Edward I.

1183. Unios in the Triassic of Massachusetts: $\Lambda \mathrm{m}$. Jour. Sci., 4th ser., vol. 38, pp. 460-462, 3 figs., November, 1914.

True, F. W.

1184. Discovery of a fossil delphinoid cetacean with tuberculate teeth: Biol. Soc. Washington, Proc., vol. 24, pp. 37-38, February 24, 1911.

Trumbull, L. W.

1185. Atlantic City gold mining district, Fremont County [Wyoming]: Wyoming, Geologist's Office, Ser. B, Bull. no. 7, pp. 69-97, 2 maps, 3 pls., 1914.

1186. The Salt Creek oil field, Natrona County, Wyoming: Wyoming, Geologist's Office, Ser. B, Bull. no. 8, pp. 103-148, 3 maps, 1914.

1187. Atlantic City gold mining district, Wyoming: Min. Sci., vol. 69, pp. 45-49, June, 1914.

Turmer, H. W., and Rogers, A. F.

1188. A geologic and microscopic study of a magmatic copper sulphide deposit in Plumas County, California, and its modification by ascending secondary enrichment: Econ. Geology, vol. 9, no. 4, pp. 359-391, 1. pl., 16 figs., June, 1914.

Turner, Homer G.

The terranes of Greensboro, Vermont. See Richardson and Turner, no. 996.

Twenhofel, W. H.

1189. A new locality and horizon for Pennsylvanian vertebrates: Science, new ser., vol. 40, pp. 26-27, July $3,1914$.

1190. The Anticosti Island faunas: Canada Geol. Survey, Mus. Bull. no. 3, 35 pp., 1 pl., October 30, 1914.

Twenhofel, W. H., and Dunbar, Carl O.

1191. Nodules with fishes from the coal measures of Kansas: Am. Jour. Sci., 4th ser., vol. 38, pp. 157-163, August, 1914.

Twitchell, M. W.

1192. The mineral industry of New Jersey for 1913: New Jersey Geol. 'Survey, Bull. 15, 46 pp., 1914.

Tyrrell, G. W.

1193. A review of igneous rock classification: Science Progress, vol. 9, pp. 60-84, July, 1914.

Tyrrell, J. B.

1194. The Patrician Glacier south of Hudson Bay: Int. Geol. Cong., XII, Canada, 1913, C. R., pp. 523-534, map, 1914.

1195. The Yukon Territory [geology, mineral resources, etc.]. In Canada and its provinces (Adam Shortt and A. G. Doughty, ed.), vol. 22, pp. 583-636, 1 pl., Toronto, Glasgow, Brook and Company, 1.914. 
Tyrrell, J. B.-Continued.

1196. The Northwest Territories [geology, mineral resources, etc.]. In Canada and its provinces (Adam Shortt and A. G. Doughty, ed.), vol. 22, pp. 637-660, 4 pls., Toronto, Glasgow, Brook and Company, 1914.

1197. Why more gold has not been found in Ontario (abstract): Min. Sci., vol. 69, pp. 32-33, February, 1914.

Tyrrell, J. B., and Graham, R. P. D.

1198. Yukonite, a new hydrous arsenate of iron and calcium, from Tagish Lake, Yukon Territory, Canada; with a note on the associated symplesite: Roy. Soc.Canada, Proc. and Trans., 3d ser., vol. 7, sect., 4, pp. 13-18, 1914.

Udden, Anton D.

1199. On the earthquake of January 2, 1912, in the upper Mississippi Valley: Illinois Acad. Sci., Trans., vol. 5, pp. 111-115, 1 fig., November, 1912.

Udden, Johan August.

1200. Some deep borings in Illinois: Illinois State Geol. Survey, Bull. no. 24, 141 pp., 4 pls. (records of wells), ${ }^{\circ} 1914$

1201. Flattening of limestone gravel boulders by solution: Geol. Soc. America, Bull., vol. 25, no. 1, pp. 66-68, 1 pl., March 30, 1914.

1202. The deep boring at Spur: Texas, Univ., Bull., Scient. Ser. no. 28, 90 pp., 18 figs., 13 pls., October 5, 1914.

1203. Mechanical composition of clastic sediments: Geol. Soc. America, Bull., vol. 25, no. 4, pp. 655-744, December, 1914.

1204. The Buck zinc prospect near Boracho, Texas: Min. and Sci. Press, vol. 108, no. 12, pp. 493-494, 1 fig., March 21, 1914.

1205. Geology and mineral resources of the Peoria quadrangle, Illinois (abstract by W. C. Alden): Washington Acad. Sci., Jour., vol. 4, no. 9, pp. 21.9221., May 4, 1914.

Uglow, W. L.

1206. "Secondary silicate zones"; a reply to criticisms by J. F. Kemp and C. A. Stewart: Econ. Geology, vol. 9, no. 2, pp. 175-183, March, 1914.

Ulrich, E. $O$.

1207. The Ordovician-Silurian boundary: Int. Geol. Cong., XII, Canada, 1913, C. R., pp. 593-667, 8 maps, 1 table, 1914.

Umpleby, Joseph B.

1208. The genesis of the Mackay copper deposits, Idaho: Econ. Geology, vol. 9, no. 4, pp. 307-358, no. 6, pp. 593-594, 10 figs., 1914.

1209. The lead-silver deposits of the Dome district, Idaho: U. S. Geol. Survey, Bull. 540, pp. 212-222, 2 figs., 1914.

1210. Ore deposits in the Sawtooth quadrangle, Blaine and Custer counties, Idaho: U. S. Geol. Survey, Bull. 580, pp. 221-249, 2 pls. (maps), 1 fig. (map), 1914.

1211. Crystallized chrysocolla from Mackay, Idaho: Washington Acad. Sci., Jour., vol. 4, no. 8, pp. 181-183, April 19, 1914.

1212. The contact metamorphic copper deposits at Mackay, Idaho (abstract): Washington Acad. Sci., Jour., vol. 4, no. 1, pp. 12-13, January 4, 1914.

1213. Some ore deposits in northwestern Custer County, Idaho (abstract): Washington Acad. Sci., Jour., vol. 4, no. 8, pp. 194-195, April 19, 1914.

Umpleby, J. B., Schaller, W. T., and Larsen, E. S.

1214. Custerit; ein neues kontaktmetamorphes Mineral: Zeitschr. Kryst. Min., Bd. 53, H. 4, pp. 321-331, 1.914. 


\section{United States Geological Survey.}

1215. Contributions to economic geology (short papers and preliminary reports), 1912; Part I, Metals and nonmetals except fuels: U. S. Geol. Survey, Bull. 540, 563 pp., 11 pls., 60 figs., 1914.

The papers in this bulletin have been entered under the individual authors.

1216. Mineral resources of the United States, calendar year, 1913; Part I, Metals, 901 pp., 8 figs., 1 insert (in pocket); Part II, Nonmetals, 1617 pp., 9 pls. (incl. maps), 26 figs., 3 inserts (in pocket), 1914.

Upham, Warren.

1217. The Sangamon interglacial stage in Minnesota and westward: Int. Geol. Cong., XII, Canada, 1913, C. R., pp. 455-465, 1914.

1218. Fields of outflow of the North American ice sheet: Int. Geol. Cong., XII, Canada, 1913, C. R., pp. 515-522, 1914.

Van Horn, Frank Robertson.

1219. Notes on a new occurrence of pisanite and arsenopyrite, and some large staurolite crystals from the Ducktown district, Tennessee: Am. Jour. Sci., 4th ser., vol. 37, pp. 40-47, 7 figs., January, 1914.

1220. The occurrence of bournonite, jamesonite, and calamine at, Park City, Utah: Am. Inst. Min. Eng., Bull., no. 92, pp. 2223-2230, 1. fig., August, 1914.

1221. Minerals from the ore deposits at Park City, Utah (abstract, with discussion): Geol. Soc. America, Bull., vol. 25, no. 1, pp. 47-48, March 30, 1914.

Van Ingen, Gilbert.

1222. Table of the geological formations of the Cambrian and Ordovician systems about Conception and Trinity bays, Newfoundland, and their northeastern-American and western-European equivalents, based upon the 1912-1913 field work. Broadside, Princeton, New Jersey, July 9, 1.914 [Private publication].

1223. Cambrian and Ordovician faunas of southeastern Newfoundland (abstract): Geol. Soc. America, Bull., vol. 25, no. 1, p. 138, March 30, 1914.

Van Orstrand, C. E., and Wright, F. E.

1224. The calculation and comparison of mineral analyses: Washington $\Lambda$ cad. Sci., Jour., vol. 4, no. 18, pp. 514-525, November 4, 1914.

Van Tuyl, Francis M.

1225. Origin of dolomite (abstract): Geol. Soc. America, Bull., vol. 25, no. 1, p. 66, March 30, 1914.

1226. The origin of geodes (abstract): New York Acad. Sci., Annals, vol. 23, p. 309, April 30, 1914.

Van Tuyl, Francis M., and Berckhemer, Fritz.

1227. A problematic fossil from the Catskill formation [Delaware Water Gap, Pennsylvania]: Am. Jour. Sci., 4th ser., vol. 38, pp. 275-276, 1 fig., September, 1.914.

Van Winkle, Walton.

1228. Quality of the surface waters of Oregon: U. S. Geol. Survey, Water-Supply Paper 363, 137 pp., map, 1 pl., 1 fig., 1914; (abstract by R. B. Dole): Washington Acad. Sci., Jour., vol. 4, no. 21, p. 607, December 19, 1914. Includes notes on the geology and on the mineralization of the waters.

1229. Quality of the surface waters of Washington (abstract by R. B. Dole): Washington Acad. Sci., Jour., vol. 4, no. 2L, p. 606, December 19, 1914. 
Vaughan, Thomas Wayland.

1230. Preliminary remarks on the geology of the Bishamas, with special reference to the origin of the Bahaman and Floridian oolite: Carnegie Inst. Washington, Pub. no. 182 (Papers from the Tortugas Laboratory, vol. 5), pp. $47-54,1914$.

1231. The building of the Marquesas and Tortugas atolls and a sketch of the geologic history of the Florida reef tract: Carnegie Inst. Washington, Pub. no. 182 (Papers from the Tortugas Laboratory, vol. 5), pp. 55-67, 1914.

1232. Sketch of the geologic history of the Florida coral reef tract and comparisons with other coral reef areas: Washington Acad. Sci., Jour., vol. 4, no. 2, pp. 26-34, January 19, 1914.

1233. Geologic history of the Florida coral-reef tract and comparisons with other coral-reef areas (abstract): Geol. Soc. America, Bull., vol. 25, jo. 1, pp. 41-42, March 30, 1914.

1234. The platforms of barrier coral reefs (abstract): Am. Geog. Soc., Bull., vol. 46, no. 6, pp. 426-429, June, 1914.

Contributions to the geology of Bermuda (abstract). See Pirsson and Vaughan, no. 956.

Vaughan, T. W., and Cooke, C. W.

1235. Correlation of the Hawthorn formation: Washington Acad. Sci., Jour., vol. 4 , no. 10 , pp. 250-253, May $19,191.4$.

Veatch, J. Allen.

1236. The genesis of the mercury deposits of the Pacific coast: Am. Inst. Min. Eng., Bull. no. 86, pp. 209-226, 3 figs. (maps); Tebruary, 1914.

Vinageras, Arturo Codeso.

1237. Notas de geologia aplicada: Acad. Cienc. Méd., Fís. Nat., Habana, Anales, t. 50, pp. $492-503,1913$.

Von Engeln, O. D.

1238. Effects of continental glaciation on agriculture: Am. Geog. Soc., Bull., vol. 46, no. 4, pp. 241-264, no. 5, pp. 336-355, 6 figs., 1914.

Wade, Bruce.

1239. The geology of Perry County and vicinity: Tennessee State Geol. Survey, Resources of Tennessee, vol. 4, no. 4, pp. 150-181, 3 figs., October, 1914.

Wade, W. Rogers.

1240. Apache mining district, New Mexico: Eng. and Min. Jour., vol. 97, no. 12, pp. 597-598, 2 figs., March 21, 1914.

1241. Mining district of Pinos Altos, New Mexico: Min. and Sci. Press, vol. 109, no. 11, pp. 402-403, September 12, 1914.

Walcott, Charles D.

1242. Cambrian geology and paleontology, II, No. 11; New Lower Cambrian subfauna (abstract by E. Kirk): Washington Acad. Sci., Jour., vol. 4, no. 1.3, pp. 371-372, July 19, 1914.

1243. Cambrian geology and paleontology, II, No. 12; Cambrian formations of the Robson Peak district, British Columbia and Alberta, Canada (abstract by E. Kirk): Washington Acad. Sci., Jour., vol. 4, no. 13, p. 372, July $19,1914$. 
Walcott, Charles D.-Continued.

1244. Cambrian geology and paleontology, II; No. 13, Dikelocephalus and other genera of the Dikelocephalinæ: Smithsonian Misc. Coll., vol. 57, no. 13, pp. 345-412, 11 pls., April 4, 1914; (abstract by E. Kirk), Washington Acad. Sci., Jour., vol. 4, no. 13, pp. 372-373, July 19, 1914.

1245. Cambrian geology and paleontology, III, No. 1; The Cambrian faunas of eastern Asia (abstract by E. Kirk): Washington Acad. Sci., Jour., vol.4, no. 14, p. 423, August 19, 1914.

1246. Cambrian geology and paleontology, III, No. 2; Pre-Cambrian Algonkian algal flora: Smithsonian Misc. Coll., vol. 64, no. 2, pp. 77-156, 20 pls., July $22,1.914$.

Walker, T. I.

1247. Crystallography; an outline of the geometrical properties of crystals. 204 pp., 5 pls., 223 figs. New York, McGraw-Hill Book Company, 1914.

1248. Temiskamite, a new nickel arsenide from Ontario: Am. Jour. Sci., 4th ser., vol. 37, pp. 170-172, 1 fig., February, 1914; (abstract), Geol. Soc. America, Bull., vol. 25, no. 1, p. 76, March 30, 1914.

Wallace, Robert C.

1249. A physico-chemical contribution to the study of dolomitization: Int. Geol. Cong., XII, Canada, 1913, C. R., pp. 875-884, 6 figs., 1914.

1250. A contribution to the study of dolomitization: Roy. Soc. Canara, Proc. and Trans., 3d ser., vol. 7, sect. 4, pp. 139-149, 6 figs., 1914.

1251. The Rice Lake gold district of Manitoba: Canadian Min. Inst., Trans., vol. 16, pp. 538-544, 1913.

1252. Gypsum and anhydrite in genetic relationship: Geol. Mag., dec.. 6, vol. 1, no. 6, pp. 271-276, June, 1914.

Gypsum and salt in Manitoba. See MacTean and Wallace, nn. 796.

Ward, Freeman.

1253. The "dam" at Cheshire, Connecticut: Am. Jour. Sci., 4th ser., vol. 37, pp. 155-156, 1. fig., February, 1914.

Waring, Clarence A.

1254. Eocene horizons of California: Jour. Geology, vol. 22, no. 8, pp. 782-785, November-December, 1914.

Includes description of new species of Mollusca from the Martinez and Tejon formations.

Waring, Gerald A.

1255. Geology and water resources of a portion of south central Washington (abstract by O. E. Meinzer): Washington Acad. Sci., Jour., vol. 4, no. 9, p. 226, May 4, 1914.

Warren, Charles H., and Powers, Sidney.

1256. Geology of the Diamond Hill-Cumberland district in Rhode Island-Massachusetts: Geol. Soc. America, Bull., vol. 25, no. 4, pp. 435-476, 3 figs., December, 1914; (abstract), Geol. Soc. America, Bull., vol. 25, no. 1, p. 75, March 30, 1914.

Washburne, Chester W.

1257. Reconnaissance of the geology and oil prospects of northwestern Oregon: U. S. Geol. Survey, Bull. 590, 111 pp., map, 1914.

1258. Chlorides in oil-field waters: Am. Inst. Min. Eng., Bull. no. 87, pp. 375-381, March, 1914; Trans., vol. 48, pp. 687-694, 191.5.

1259. The capillary concentration of gas and oil: Am. Inst. Min. Eng., Bull., no. 93, pp. 2365-2378, September, 1914. 
Watson, Thomas Leonard.

1260. Administrative report of the State geologist for the biennial period 1912-1913: Virginia Geol. Survey, 49 pp., 1914.

1261. The rutile deposits of the eastern United States: U. S. Geol. Survey, Bull. 580, pp. 385-412, 5 figs. (maps), 1914.

1262. Memorial of William M. Fontaine: Geol. Soc. America, Bull., vol. 25, no. 1, pp. 6-12, port., March 30, 1914.

Engineering geology. See Ries and Watson, no. 1007.

Watson, Thomas L., and Grasty, J. S.

1263. The Piedmont limeston es of the southeast Atlantic States (abstract): Science new ser., vol. 39, p. 399, March 13, 1914.

1264. The cement materials and industry of the Southern States (abstract): Science, new ser., vol. 39, p. 400, March 13, 1914.

Watson, Thomas L., Cline, Justus H., and Harnsberger, T. K.

1265. Examples of intercision type of stream piracy in western Virginia: Virginia Univ., Pub., Bull. Philos. Soc., Sci. Ser., vol. 1, no. 20, pp. 437-442, 4 figs., July, 1914.

Weaver, Charles $\mathrm{E}$.

1266. Lower Miocene of Washington (abstract): Geol. Soc. America, Bull., vol. 25, no. 1, pp. 153-154, March 30, 1914.

Weeks, Walter Scott, and Huntington, Edward V.

1267. The faultless faultfinder: Eng. and Min. Jour., vol. 98, no. 7, pp. 291-296, 10 figs., August 15, 1914.

Wegemann, Carroll, H.

1268. Geology and coal resources of the Sierra Blanca coal field, Lincoln and Otero counties, New Mexico: U. S. Geol. Survey, Bull. 541, pp. 419-452, 1 fig., 2 maps, 1914.

Weller, Stuart.

1269. Stratigraphy of the Chester group in southwestern Illinois: Illinois Acad. Sci., Trans., vol. 6, pp. 118-129, February, 1913.

1270. The Mississippian Brachiopoda of the Mississippi Valley basin: Illinois State Geol. Survey, Mon. 1, 508 pp., 83 pls., 1914.

Weller, Stuart, and Mehl, M. G.

1271. Western extension of some Paleozoic faunas in southeastern Missouri (abstract): Geol. Soc. America, Bull., vol. 25, no. 1, pp. 135-136. March 30, 1914.

Wells, Roger C.

1272. The interpretation of mineral analyses: Washington Acad. Sci., Jour., vol. 3, no. 15, pp. 416-423, September 19, 1913.

1273. Electric activity in ore deposits: U. S. Geol. Survey, Bull. 548,78 pp., 7 figs., 1914.

Welsh, Norval J.

1274. The Organ Mountain district [New Mexico]: Eng. and Min. Jour., vol. 98, no. 8, pp. 331-334, 2 figs., map, August 22, 1914.

Weston, W.

1275. The Yampa coal field of Routt County, Colorado, on the line ... of the Denver and Salt Lake Railroad (Moffat Road). Report on the above. 62 pp., map, 1914 edition. 


\section{West Virginia Geological Survey.}

1276. Map of West Virginia showing coal, oil, gas, iron ore, and limestone areas. Scale: 8 miles to the inch. 1914.

$\Lambda$ revision of the map of 1913.

Wheeler, H. A.

1277. The Illinois oil fields: Am. Inst. Min. Eng., Bull. no. 89, pp. 881-912, 4 figs., May, 1914; Trans., vol. 48, pp. 533-563, 4 figs., 1915.

Wheeler, W. C.

The composition of crinoid skeletons. See Clarke and Wheeler, no. 241.

Wherry, Edgar T.

1278. Carnotite near Mauch Chunk, Pennsylvania: U. S. Geol. Survey, Bull. 580, pp. 147-151, 1914.

1279. Variations in the compositions of minerals: Washington Acad. Sci., Jour., vol. 4, no. 5, pp. 111-114, March 4, 1914.

1280. Mineral nomenclature: Science, new ser., vol. 39, pp. 575-577, April 17, 1914.

1281. Notes on wolframite, beraunite, and axinite: U. S. Nat. Mus., Proc., vol. 47, pp. 501-511, October 24, 1914.

1282. The occurrence of carnotite in eastern Pennsylvania (abstract): Washington Acad. Sci., Jour., vol. 4, no. 11, p. 296, June 4, 1914.

White, David.

1283. Resins in Paleozoic plants and in coals of high rank: U. S. Geol. Survey, Prof. Paper 85, pp. 65-83, 6 pls., March 25, 1914; (abstract), Washington Acad. Sci., Jour., vol. 4, no. 9, p. 225, May 4, 1914.

1284. Resins in Paleozoic coals (abstract): Washington Acad. Sci., Jour., vol. 4, no. 1, p. 10, January 4, 1914.

White, David and Thiessen, Reinhardt.

1285. The origin of coal: U. S. Bur. Mines, Bull. 38, 390 pp., 54 pls., 191.3.

White, I. C.

1286. Introduction [to the history and physiography of Kanawha County, West Virginia]: West Virginia Geol. Survey, Kanawha County, pp. xviixxviii, 1914.

1287. Deepest boring in West Virginia (abstract): Geol. Soc. America, Bull., vol. 25, no. 1, p. 4.8, March 30, 1914.

White, James.

1288. Alfred E. Barlow: Canadian Min. Inst., Monthly Bull., no. 27, pp. 51-54, July, 1914.

Whitehead, W. L.

A deposit of jamesonite near Zimapan, Mexico. See Lindgren and White. head, no. 754 .

Whitford, A. C.

1289. On a new fossil fungus from the Nebraska Pliocene: Nebraska Univ. Studies, vol. 14, no. 2, pp. 181-183, 2 pls., April, 1914.

Describes Cladosporites ligni-perditor $\mathrm{n}$. $\mathrm{sp}$.

Whitman, Alfred R.

1290. Notes on the copper ores at Ely, Nevada: California, Univ., Dept. Geology, Bull., vol. 8, no. 17, pp. 309-31.8, 2 pls., December 5, 1.914. 
Whitney, Milton, and others.

1291. Field operations of the Bureau of Soils, 1911. U. S. Dept. Agr., Bur. Soils, Thirteenth Report. 2356 pp., 27 pls., 61 figs., and 50 soil maps (in separate case). Washington, 1914.

Contains soil surveys of the following areas:

Alabama, Chilton County, pp. 689-720.

EImore County, pp. 721-763.

Jackson County, pp. 765-792.

Madison County, pp. 793-830

Marshall County, pp. 831-858.

Mobile County, pp. 859-896.

Randolph County, pp. 897-932.

Tuscaloosa County, pp. 933-1002.

Arkansas, Ozark region, reconnaissance survey, pp. 1727-1873.

Connecticut, Windham County, pp. 69-93.

Georgia, Chatham County, pp. 563-592.

Columbia County, pp. 645-687.

Glynn County, pp. 593-643.

Kansas, Reno County, pp. 1991-2058.

Shawnee County, pp. 2059-2095.

Louisiana, Iberia Parish, pp. 1129-1174.

Massachusetts, Plymouth County, pp. 31-67.

Mississippi, Forrest County, pp. 1003-1050.

Lowndes County, pp. 1083-1128.

Wayne County, pp. 1051-1081.

Missouri, Franklin County, pp. 1603-1633.

Laclede County, pp. 1635-1675.

Macon County, pp. 1677-1700.

Ozark region, reconnaissance survey, pp. 1727-1873.

Platte County, pp. 1701-1725.

Nebraska, western, reconnaissance survey, pp. 1875-1989.

New Jersey, Sussex area, pp. 329-386.

New York, Jefferson County, pp. 95-173.

North Carolina, Johnston County, pp. 431-478.

Richmond County, pp. $387-430$

Oregon, Medford area, pp. 2287-2356.

Pennsylvania, Bedford County, pp. 175-230.

Bradford County, pp. 231-267.

northeastern, reconnaissance survey, pp. 269-327.

South Carolina, Fairfield County, pp. 479-511.

Georgetown County, pp. 513-562.

Texas, southwest, reconnaissance survey, pp. 1175-1285.

Washinglon, Quincy area, pp. 2227-2286.

southwestern, reconnaissance survey, pp. 2097-2226.

West Virginia, Huntington area, pp. 1287-1326.

Morgantown area, pp. 1327-1364.

Wisconsin, Columbia County, pp. 1365-1421.

Fond du Lac County, pp. 1423-1461.

Juneau County, pp. 1463-1512.

Kewaunee County, pp. 1513-1559.

Wickham, H. F.

La Crosse County, pp. 1561-1601.

1292. New Miocene Coleoptera from Florissant: Harvard Coll., Mus. Comp. Zool., Bull., vol. 58, no. 11, pp. 423-494, 16 pls., December, 1914.

Wieland, G. R.

1293. On the dinosaur-turtle analogy: R. Accad. Sci. Ist. Bologna, Cl. Sc. Fis., Mem., ser. 6, t. 9, pp. 297-300, 1912.

1294. Further notes on Ozarkian seaweeds and oölites: Am. Mus. Nat. Hist., Bull., vol. 33, pp. 237-260, 6 pls., 2 figs., 1914. 
Wieland, G. R.-Continued.

1295. A study of some American fossil cycads; Part VII, Further notes on disk structure: Am. Jour. Sci., 4th ser., vol. 38, pp. 117-136, 9 figs., August, 1914.

1296. Was the Pterophyllum foliage transformed into the leafy blades of dicotyls?: Am. Jour. Sci., 4th ser., vol. 38, pp. 451-460, 3 figs., November, 1914.

Cordaitean wood from the Indiana black shale. See Elkins and Wieland, no. 386 .

Wilder, Frank A.

1297. The gypsum resources of the Southern States (abstract): Science, new ser., vol. 39 , p. 400, March 13, 1914.

Williams, Henry s.

Description of the Eastport quadrangle, Maine. See Bastin and Williams, no. 60 .

\section{Williams, Ira A.}

1298. The occurrence of coal in Squaw Creek Basin, Coos County, Oregon: Oregon Bur. Mines and Geol., Mineral Resources of Oregon, vol. 1, no. 1, pp. 28-48, 3 pls., 1. sketch map, January, 1914.

1299. Limestone deposits in Oregon: Oregon Bur. Mines and Geol., Mineral Resources of Oregon, vol. 1, no. 7, pp. 52-70, November, 1914.'

Williams, Merton $Y$.

1300. Arisaig-Antigonish district, Nova Scotia: Canada Geol. Survey, Mem. 60, 173 pp., 2 maps (in pocket), 1914.

1301. The Silurian of Manitoulin Island and western Ontario: Canada Geol. Survey, Summ. Rept. 1912, pp. 275-281, 1914.

1302. Thedford and vicinity, Ontario: Canada Geol. Survey, Summ. Rept. 1912, pp. 282-285, 1914.

1303. Stratigraphy of the Niagara escarpment of southwestern Ontario: Canada Geol. Survey, Summ. Rept. 1913, pp. 178-188, 2 figs., 1914.

1304. Sections illustrating the lower part of the Silurian system of southwestem Ontario (abstract): Geol. Soc. America, Bull., vol. 25, no. 1, pp. 40-41, March 30, 1914.

Williams, Stephen $R$.

1305. A starfish found in the Whitewater division of the Richmond on Blue Creek, Adams County, Ohio: Ohio Naturalist, vol. 14, no. 3, pp: 221-224, 2 figs., January, 1914.

Williston, Samuel Wendell.

1306. Water reptiles of the past and present. vii, 251 pp., 131 figs. Chicago, The University of Chicago Press, 1914.

1307. Broiliellus, a new genus of amphibians from the Permian of Texas: Jour. Geology, vol. 22, no. 1, pp. 49-56, 3 figs., January-February, 1914.

1308. Restorations of some American Permocarboniferous amphibians and reptiles: Jour. Geology, vol. 22, no. 1, pp. 57-70, 11 figs., 1914.

1309. The osteology of some American Permian vertebrates: Jour. Geology, vol. 22, no. 4, pp. 364-419, 19 figs., May-June, 1914; Walker Mus., Contr., . vol. 1, no. 8, pp. 107-162, 19 figs., 1914.

1310. The American land vertebrate fauna and its relations (abstract): Science, new ser., vol. 40, pp. 777-778, November $27,1914$.

Wilson, Alice E.

1311. A preliminary study of the variations of the plications of Parastrophia hemiplicata, Hall: Canacla Geol. Survey, Mus. Bull. no. 2, pp. 131-139, 1 pl., July 11, 1914. 
Wilson, J. Howard.

1312. A glacially formed lake in Susquehanna County, Pennsylvania: Am. Geog. Soc., Bull., vol. 46, no. 9, pp. 659-661, map, 3 figs., September, 1914.

Wilson, M. E.

1313. Kewagama Lake map-area, Quebec: Canada Geol. Survey, Men. 39, 134 pp., 29 pls., 9 figs., 1 map (in pocket), 1913.

1314. A geological reconnaissance from Lake Kipawa via Grand Lake Victoria to Kanikawinika Island, Bell River, Quebec: Canada Geol. Survey, Summ. Rept. 1912, pp. 315-336, 1 fig., map, 1914.

1315. Southeastern portion of Buckingham map area, Quebec: Canada Geol. Survey, Summ. Rept. 1913, pp. 196-207, 1914.

Wilson, Philip D.

1316. A cavern in the Shattuck mine [Bisbee, Arizona]: Eng. and Min. Jour., vol. 97, no. 15, pp. 743-744, 4 figs., April 11, 1914.

Wilson, W. J.

1317. Paleobotany: Canada Geol. Survey, Summ. Rept. 1912, pp. 407-410, 1914.

1318. Paleobotany: Canada Geol. Survey, Summ. Rept. 1913, pp. 322-326, 1914.

Winchell, Alexander N.

1318. Mining districts of the Dillon quadrangle, Montana, and adjacent areas: U. S. Geol. Survey, Bull. 574, 191 pp., 8 pls., 16 figs., 1914.

1320. Petrology and mineral resources of Jackson and Josephine counties, Oregon: Oregon Bur. Mines and Geol., Mineral Resources of Oregon, vol. 1, no. 5, 265 pp., 33 figs., 11 pls., August, 1914.

Winchell, Newton $\mathrm{H}$.

1321. Review of the formation of geological societies in the United States: Geol. Soc. America, Bull., vol. 25, no. 1, pp. 27-30, March 30, 1914.

1322. The foundation of the Geological Society of America: Science, new ser., vol. 39, pp. 819-821, June 5, 1914.

1323. Delaware terraces (abstract): Geol. Soc. America, Bull., vol. 25, no. 1, p. 86, March 30, 1914.

Winchester, D. E.

1324. The upper Cretaceous formations of western New Mexico and their relations to the underlying rocks (abstract): Washington Acad. Sci., Jour., vol. 4, no. 11, p. 300, June 4, 1914.

Wolff, Wilhelm.

1325. Glazialgeologische Exkursionen des XII. Internationalen Geologenkongresses zu Toron to 1913: Centralbl. Mineralogie, no. 11, pp. 334-350; no. 12, pp. 374-384, 1 fig.; no. 13, pp. 405-416, 1914.

Wood, Elvira.

1326. The use of crinoid arms in studies of phylogeny: New York Acad. Sci., Annals, vol. 24, pp. 1-17, 5 pls., 1 fig., May 1, 1914; (abstract) Geol. Soc. America, Bull., vol. 25, no. 1, p. 135, March 30, 1914.

Wood, Harry $\mathrm{O}$.

1327. Concerning the perceptibility of weak earthquakes and their dynamical measurement: Seeismol. Soc. America, Bull., vol. 4, no. 1, pp. 29-38, March, 1914.

1328. On the earthquakes of 1868 in Hawaii: Seismol. Soc. America, Bull., vol. 4, no. 4, pp. 169-203, 2 figs., December, 1914.

Woodbridge, Dwight E.

1329. The possibilities of the Cuban iron deposits: Min. and Eng. World, vol. 40, no. 11, pp. 511-513, l fig., March 14, 1914. 
Woodman, J. E.

1330. The interbedded iron ores of Nova Scotia (abstract): New York Acad. Sci., Annals, vol. 23, p. 274, April 30, 1914.

Woodruff, E. G.

1331. The Horseshoe Creek district of the Teton Basin coal field, Fremont County, Idaho: U. S. Geol. Survey, Bull. 541, pp. 379-388, 1 fig., map, 1914.

1332. The Glacier coal field, Whatcom County, Washington: U. S. Geol. Survey, . Bull. 541, pp. 389-398, 1 fig., map, 1914.

Woodruff, E. G., and Day, David T.

1333. Oil shale of northwestern Colorado and northeastern Utah: U. S. Geol. Survey, Bull. 58.1, pp. 1-2.1, 1 pl: (map), 1914.

1334. Bituminous shale in northwestern Colorado and northeastern Utah (abstract): Washington Acad. Sci., Jour., vol. 4, no. 7, pp. 170-171, April. 4, 1914.

Woodworth, J. B.

1335. Harvard seismographic station: Fifth annual report including records, 1 August, 1912 to 31. December, 1913: Harvard Coll., Mus. Comp. Zool., Bull., vol. 55, no. 3 (Geol. ser., vol. 9, no. 3), pp. 55-77, October, 1914.

Woolsey, W. J.

1336. Asbestos resources of the Thetford area [Quebec]: Canadian Min. Inst., Monthly Bull., no. 27, pp. 103-106, 2 figs., July, 1914.

Wooster, Lyman C.

1337. Notes on the moraine of the glacier southwest of Topeka: Kansas Acad. Sci., Trans., vol. 25, pp. 43-44, 1 fig., 1913.

1338. Geological development of Kansas: Kansas Acad. Sci., Trans., vol. 26, pp. 55-69, 1914.

Worrell, S. H.

The fuels used in Texas. See Phillips and Worrell, no. 950.

Wright, Arthur W.

1339. Benjamin Silliman, 1816-1885: Nat. Acad. Sci., Biog. Mem., vol. 7, pp. 115-141, port., 1911.

Wright, Fred. Eugene.

1340. The optical properties of roscoelite: Am. Jour. Sci., 4th ser., vol. 38, pp. 305-308, October, 1914.

1341. Change in the crystallographical and optical properties of quartz with rise in temperature (abstract, with discussion): Geol. Soc. America, Bull., vol. 25, no. 1, p. 44, March 30, 1914 .

Hewettite, metahewettite, and pascoite, hydrous calcium vanadates. See Hillebrand, Merwin, and Wright, no. 541.

The calculation and comparison of mineral analyses. Van Orstrand and Wright, no. 1224.

Wright, Fred. E., and Rankin, G. A.

1342. Physical-chemical system, lime-alumina-silica and its geological significance (abstract): Geol. Soc. America, Bull., vol. 25, no. 1, p. 92, March $30,1914$.

Wright, G. Frederick.

1343. Recent date of the attenuated glacial border in Pennsylvania: Int. Geol. Cong., XII, Canada, 1913, C. R., pp. 451-453, map, 1914. 
Wright, G. Frederick-Continued.

1344. Age of the Don River glacial deposits, Toronto, Ontario: Geol. Soc. America, Bull., vol. 25, no. 2, pp. 205-214, 3 figs., June 18, 1914; (abstract, with - discussion), Geol. Soc. America, Bull., vol. 25, no. 1, pp. 71-73, March $30,1914$.

1345. Evidence of a glacial dam in the Allegheny River between Warren, Pennsylvania, and Tionesta: Geol. Soc. America, Bull., vol. 25, no. 2, pp. 215-218, 1 pl., 1 fig., June 18, 1914; (abstract): Geol. Soc. America, Bull., vol. 25, no. 1, pp. 84-85, March 30, 1914.

Wright, H. F.

The road and concrete materials of Iowa. See Beyer and Wright, no. 90.

Wright, W. B.

1346. The Quaternary ice age. 464 pp., 23 pls., 155 figs. London, MacMillan and Co., 1914.

Includes chapters on the glaciation, Quaternary lakes, and late glacial changes of level in North America.

Wright, W. H.

1347. A journey to Lassen Peak [California]: Eng. and Min. Jour., vol. 98, no. 3, pp. 97-100, 5 figs., July 18, 1914.

Wright, W. J.

1348. Geology of the neighborhood of New Ross, Lunenburg County, Nova Scotia: Canada Geol. Survey, Summ. Rept. 1912, pp. 384-389,-1914.

1349. Geology of the Moncton map area, New Brunswick: Canada Geol. Survey, Summ. Rept. 1913, pp. 223-227, 1 fig. (diagram), 1914.

1350. Geology of Clyburn Valley, Cape Breton [Island, Nova Scotia]: Canada Geol. Survey, Summ. Rept., 1913, pp. 270-283, map, diagram, 1914.

Yale, Charles G., and Gale, Hoyt S.

1351. Magnesite; borax: U. S. Geol. Survey, Mineral Resources, 1913, pt. 2, pp. 441-454, map, 521-536, map, 1914.

Young, G. J.

1352. Potash salts and other salines in the Great Basin region: U. S. Dept. Agr., Bull. no. 61, 96, pp. 6 pls., 8 figs., 1914.

Ziegler, Victor.

1353. The minerals of the Black Hills [South Dakota]: South Dakota School of Mines, Bull. no. 10, 250 pp., 31 pls., 73 figs., 1914.

NotE.-Minerals have not been included in list of minerals described on page 143.

1354. The differentiation of a granitic magna as shown by the paragenesis of the minerals of the Harney Peak region, South Dakota: Econ. Geology, vol. 9, no. 3, pp. 264-277, April, 1914.

1355. 'The mineral resources of the Harney Peak [South Dakota] pegmatites: Min. and Sci. Press, vol. 108, no. 15, pp. 604-608, map, 2 figs; no. 16, pp. 654-656, 3 figs., April 11 and 18, 1914.

1356. A note on two new Black Hills minerals: Pahasapa Quart., vol, 4, no. 1, pp. 14-16, December, 1914.

Zulch, W. G.

Solution of a landslide fault. See Smith and Zulch, no. 1110.

\section{Anonymous.}

1357. Explorations and field work of the Smithsonian Institution in 1913: Smithsonian Misc. Coll., vol. 63, no. 8, 88 pp., 87 figs., 1914.

Includes brief accounts of geologic work in the Canadian Rockies and in the Appalachian Valley in Maryland and of the collecting of fossils at various localities, 


\section{CLASSIFIED SCHEME OF SUBJECT HEADINGS.}

1. GENERAI.

Associations, meetings; Addresses; History; Philosophy; Biography; Bibliography; Educational; Text-books.

Classification; Nomenclature; Cartography; Technique; Field work; Surveys; Borings.

Geochemistry; Chemical analyses (list); Atmosphere; Radioactivity.

Experimental investigations; Miscellaneous.

\section{REGIONAL.}

The States of the Union, Alabama, etc.; the Provinces of Canada, Alberta, etc.; Greenland; Mexico; the countries of Central America; the West Indies, and the single islands; the Hawaiian Islands.

\section{ECONOMIC..}

Ore deposits, origin; Contact phenomena.

Gold; Placers; Black sands; Silver; Quicksilver; Nickel; Cobalt; Copper; Lead; Zinc; Iron; Magnetite; Manganese; Tin; Aluminum; Bauxite; Antimony; Bismuth; Tungsten; Wolframite; Vanadium; Uranium; Carnotite ores; Molybdenum; Molybdenite; Titanium; Rutile; Platinum; Iridium; Rhodium; Palladium; Cadmium; Monazite; Rare earths; Tantalum; Selenium; Tellurium; Zircon.

Coal; Anthracite; Coke; Peat; Lignite; Bituminous rock; Natural gas; Petroleum; Oil shales; Asphalt; Albertite; Gilsonite; Grahamite; Ozokerite.

Stone; Building stone; Granite; Bluestone; Limestone; Lime; Marble; Onyx; Sandstone; Clay; Kaolin; Bentonite; Fire clay; Ganister; Slate; Shale; Marl; Sand; Glass sand; Sand-lime brick; Gravel; Cement and cement materials; Concrete materials; Road materials; Trap; Steatite; Soapstone; Talc; Serpentine.

Precious stones; Diamonds; Sapphires; Turquoise; Tourmaline.

Abrasive materials; Corundum; Emery; Garnet; Diatomaceous earth; Tripoli; Volcanic ash; Millstones; Novaculite.

Asbestos; Feldspar; Mica; Quartz; Gypsum; Graphite; Fuller's earth; Infusorial earth; Magnesite; Mineral paint; Chromium; Chromite; Chromic iron ore; Fluorspar; Barite; Barytes; Strontium; Arsenic; Pyrite; Sulphur; Sulphate of soda; Cryolite; Phosphorus; Phosphate; Apatite; Potash; Alunite; Glauconite; Borax; Bromine; Salt; Natron deposits.

\section{DYNAMIC AND STRUCTURAL.}

Earth, genesis of; Earth, age of; Earth, interior of; Earth, temperature of. Volcanism; Volcanoes; Earthquakes; Seismology; Seismographs; Mud volcanoes. Isostasy; Orogeny; Changes of level.

Magmas; Intrusions; Dikes; Laccoliths; Metamorphism; Contact phenomena.

Deformation; Folding; Faulting; Unconformities.

Conglomerates; Concretions; Stalactites; Jointing; Cleavage.

Sedimentation; Denudation; Erosion; Caves; Sink holes; Erratic bowlders; Weathering; Wind work; Dunes; Loess; Landslides.

Glaciers; Glacial erosion; Eskers; Kames; Moraines; Kettle holes.

Drainage changes.

$$
97921^{\circ}-\text { Bull. } 617-15-7
$$


5. PHYSIOGRAPHIC.

Geomorphy; Relief maps.

Valleys; Circues; Deserts; Dunes; Deltas; Alluvial fans; Eskers; Kames; Mounds, natural; Natural bridges; Sink holes; Karsts.

Lakes; Swamps; Marshes; Everglades; Terraces; Beaches; Shore lines; Rivers; Meanders; Falls; 'Springs.

\section{HISTORIC OR STRATIGRAPHIC.}

Geologic history; Geologic time; Paleogeography; Paleogeographic maps; Paleoclimatology.

Geologic maps; Geologic formations described (list).

Pre-Cambrian; Paleozoic (undifferentiated); Cambrian; Ordovician; Silurian; Devonian; Carboniferous; Triassic; Jurassic; Cretaceous; Tertiary; Quaternary; Recent; Glacial geology; Glaciation; Glacial lakes; Ice ages.

\section{PALEONTOLOGY.}

Geographic distribution; Evolution; Restorations.

Vertebrata; Man, fossil; Mammalia; Aves; Reptilia; Amphibia; Pisces; Footprints, fossil.

Invertebrata; Arthropoda; Crustacea; Trilobita; Ostracoda; Insecta; Arachnida; Myriapoda.

Mollusca; Cephalopoda; Gastropoda; Pelecypoda.

Molluscoidea; Brachiopoda; Bryozoa; Vermes.

Echinodermata; Echinoidea; Asteroidea; Crinoidea; Cystoidea.

Colenterata; Anthozoa; Hydrozoa; Graptolites.

Protozoa; Spongida; Foraminifera.

Paleobotany; Diatoms.

Problematica.

\section{Petrology.}

Rocks, origin; Rocks, structural features; Rocks described (list); Igneous and volcanic rocks; Rock-forming minerals; Lava; Oolite; Pebbles.

\section{MINERALOGY.}

Minerals described (list); Crystallography ; Pseudomorphism; Paragenesis of minerals; Rock-forming minerals; Meteorites.

10. UNDERGROUND WATER.

Mine waters; Thermal waters; Geysers; Springs; Mineral waters.

11. SoIns 


\section{INDEX.}

[The numbers refer to entries in the bibliography.]

\section{Abrasive materials.}

United States: Katz, 637.

\section{Addresses.}

Earth's crust: Holland, 558.

Hawaiian volcanoes: Jaggar, 612 .

Pioneers in Gulf Coastal Plain geology: Smith, 1099.

Relation of geology to mining: Hatch, 516.

Ajo copper district, Arizona: Joralemon, 634.

Alabama.

Economic.

Tron, northeast Alabama: Burchard, 150.

Russellville iron district: Sawyer, 1033.

\section{Paleontology.}

Trapa: Berry, 85.

\section{Alaska.}

General.

Broad Pass region: Moffit, 855 .

Water powers: Ellsworth and Davenport, 389 .

Economic.

Barite, Wrangell: Burchard, 151, 153.

Chisana district: Brooks, 123; Cairnos, 188.

Coal: Crane, 279.

Bering River field: Fisher and Calvert, 422.

Fairbanks district: Chapin, 218.

Hanagita-Bremner region: Moffit, 854 .

Iditarod-Ruby region: Falkin, 373.

Ketchikan region: Smith, 1106.

Lignite, Cook Inlet and Kachemak Bay: Crane, 280.

Marble, Juneau, Skagway, and Sitka districts: Burchard, 152.

Matanuska and Nelchina valleys: Martin and Mertie, 808.

Mineral resources, 1913: Brooks, 122.

Nelchina Valley: Martin and Mertie, 808.

Port Wells district: Johnson, 618.

Prince William Sound: Johnson, 617.

Ruby district: Eakin, 374.

Seward Peninsula: Chapin, 220, 221.

Valdez Creek district: Moffit, 856.

Willow Creek district: Capps, 202.

Yakataga district: Maddren, 798.

Yukon-Koyukuk region: Eakin, 375.

Yukon-Tanana region: Chapin, 219.

Dynamic and structural.

Glaciers, variation 1913: Reid, 989.

Glaciers, Yakutat Bay, Prince William Sound, and Copper River region: Tarr and Martin, 1157.

\section{Physiographic.}

General: Brooks, 125.

Glacier Bay: Martin, 810 .
Alaska-Continued.

Stratigraphic.

Ellipsoidal lavas, Prince William Sound: Capps, 203.

Hanagita-Bremner region: Moflit, 854 .

Iditarod-Ruby region: Eakin, 373.

Mount St. Elias region, Quaternary history: Maddren, 799.

Yakataga district: Maddren, 798.

Yukon-Alaska boundary: Cairnes, 186, 187, 189.

Yukon-Koyukuk region: Eakin, 375.

Palcontology.

Jurassic flora, Capo Lisburne: Knowlton, 690.

\section{Alberta.}

Economic.

Bituminous sands, northern Alberta: Ells, 387, 388.

Calgary oil field: Ellsworth, 390 .

Clay: Ries, 1004.

Clay and shale deposits: Ries and Keele, 1006.

Coal, North Saskatchewan River: Dowling, 36i3.

Coal, South Fork district: MacKenzie, 792.

Jasper Park coal field: O'Neal, 891.

Oil and gas, Sheep River field: Dowling, 362,364.

Smoky River coal field: O'Neal, 890 .

South Fork coal area, Oldman River: Mackenzie, 792.

Physiographic.

Rocky Mountains: Fay, 410.

Stratigraphic.

Banff-Golden: Allan, 6.

Crowsnest volcanics: Mackenzie, 794.

Field area: $A$ llan, 5 .

Sheep River field: Dowling, 362, 364 .

South Fork coal area, Oldman River: Mackenzie, 792 .

Paleontology.

Anchiceratops, Edmonton Cretaceous: Brown, 134.

$\Lambda$ spideretes, Belly River formation: Lambe, 709.

Corythosaurus, Belly River Cretaceous: Brown, 136.

Dinosauria, Belly River formation: Lambe, 706-708.

Gryposaurus, Belly River formation: Jambe, 707.

Leptoceratops, Edmonton Cretaceous: Brown, 137.

Monoclonius, Belly River Cretaceous: Brown, 135.

Platysomus, Banf: Lambe, 710 .

\section{Petrology.}

Crowsnest volcanics: MacKenzie, 794. 
Albertella fauna: Burling, 157.

Alexandrian series: Savage, 1031.

Algæ.

Algonkian: Walcott, 1246.

Cryptozoon: Wieland, 1294.

Ozarkian seaweeds and oolites: Wieland, 1294.

Algonkian. See Pre-Cambrian.

Alleghany district, Cal.: Ferguson, 417.

Altiplanation: Eakin, 376.

Aluminum.

United States: P.halen, 943.

Alunite.

Arizona, Patagonia: Scbrader, 1045.

Nevada, Bovard: Schrader, 1048.

Ammonites. See Cephalopoda.

\section{Amphibia.}

Broiliellus, Texas: Williston, 1307.

Distribution, etc., Carboniferous: Williston, 1310.

Frogs: Moodie, 857.

Restorations of Permocarboniferous forms: Williston, 1308 .

Amphiboles, optical study: Ford, 432.

Analyses, average: Mead, 826.

Analyses, chemical. See list, p. 142.

Anatexis: Sederholm, 1064 .

Anchiceratops, Alberta: Brown, 134.

Angle of shear: Dahlblom, 297.

Animikie. See Pro-Cambrian.

Anthozoa (corals).

Zaphrentis, revision: O'Connell, 883 .

\section{Anthracite.}

British Columbia, Groundhog field: Evans, 397. Rhode Island: Ashley, 23.

Anticosti Island faunas: Twenhofel, 1190.

Antigorite, genesis: Julien, 635.

\section{Antigua.}

General: Brown, 130.

Stratigraphic.

General: Brown, 130.

Paleontology.

Fresh-water mollusks, Oligocene: Brown and Pilsbry, 132.

\section{Antimony.}

Mexico, Zimapan (Fidalgo): Lindgren and Whitehead, 754.

United States: Hess, 529.

$\Lambda$ pache district, New Mexico: Wade, 1240.

\section{Apatite.}

Now Jersey, Raritan quadrangle: Bayley et at., $6 \dot{6}$.

Apishapa quadrangle, dike rocks: Cross, 288.

\section{Arachnida.}

Nebraska, Carboniferous eurypterids: Barbour, 38.

Aræoscelis, Texas, Permian: Williston, 1349.

Archean. See Pro-Cambrian.

Archosauria: Huene, 590.

\section{Arctic regions. \\ Stratigraphic. \\ Ellesmere Land: Holtedahl, 562. \\ Paleontology. \\ Ellesmere Land: Holtedahl, 562.}

Paleozoic: Schuchert, 1055 .

Arcuate mountains, formation of: Hobbs, 546 .

\section{Arizona.}

\section{Economic.}

Ajo copper district: Joralemon, 634 .

Alunite, Patagonia: Schrader, 1045.

Bisbee ore deposits: Notman, 882 .

Buckskin Mountains: Blanchard, 96.

Celestite: Phalen, 942.

Copper, Bisbee district: Notman, 882; Tenney, 1163.

Superior: Ransome, 973.

White Mesa district: Hill, 537.

Copper Creek district: Hafer, 506.

Globe district: Tovote, 1178 .

Grand Gulch mining region, Mohave County: Hill, 539 .

Iron, hematite: Blanchard, 96.

Patagonia district: Probert, 964.

Dynamic and structural.

Cavern, Shattuck mine, Bisbee: Wilson, 1316.

Physiographic.

General: . Huntington, 598.

Coon Butte: Pickering, 952.

Grand Canyon district: Noble, $\mathbf{8 8 0}$.

Little Colorado Valley: Gregory, 497.

Meteor Crater: Merrill, 836.

Stratigraphic.

Buckskin Mountains: Blanchard, 96.

Little Colorado Valley: Gregory, 497.

Shinumo quadrangle: Noble, 880 .

Paleontology.

Fossil trees: Briscoe, 119.

Petrology.

Buckskin Mountains: Blanchard, 96.

Mineralogy.

Meteorites, Arispe: Farrington, 409.

Woliramite, Phoenix: Wherry, 1281.

\section{Arkansas.}

Economic.

Coal, Sebastian Co.: Hackett, 505.

Diamond-bearing peridotite: Miser, 853 .

Fort Smith-Poteau gas field: Smith, 1097.

Dynamic and structural.

Sulphur Springs deposits: Siebenthal, 1086.

Stratigraphic.

Fort Smith-Poteau gas field: Smith, 1097.

Underground water.

Sulphur Springs: Siebenthal, 1086.

\section{Arsenic.}

United States: Hess, 529 .

Artesian waters and wells. See Underground water.

Arthropoda. See Arachnida; Crustacea; Insecta. Artiodactyla, bunodont: Sinclair, 1091.

\section{Asbestos.}

Arizona, Grand Canyon district: Noble, 880 .

Georgia: Hopkins, 568, 569.

Quebec, southern: Dresser, 367, 368 .

Thetford: Woolsey, 1336 .

United States: Diller, 355 . 
Asphalt. See also Asphaltite and Grahamite. Kentucky: Crump, 294.

Edmonson and Grayson counties: Bryant, 147.

United States: Day, 329 .

Aspideretes, Belly River formation, Alberta: Lambe 709 .

\section{Associations, meetings.}

American Association for the Advancement of Science, Geology, A tlanta meeting, 1913-4: Kay, 639.

Geological Society of America, foundation: Winchell, 1322.

history: Fairchild, 401

organization: Stevenson, 1128.

Princeton meeting, 1913: Hovey, 578.

Cordilleran section, meeting 1913: Louderback, 763 .

Geological societies in United States: Winchell, 1321.

International Geological Congress, Canada: Int. G. C., 609.

Paleontological Society, Princeton meeting, 1913-4: Bassler, 55, 56.

Pacific section, fourth meeting: Dickerson, 344.

Asteroidea.

Classification and catalogue of Paleozoic starfish: Schuchert; 1050

Ohio, Adams Co., starfish: Williams, 1305.

Asthenosphere: Barrell, 47, 48.

Atolls, formation: Vaughan, 1234.

Attica quadrangle, N. Y.: Luther, 775.

Aves (birds).

California, Pleistocene, San Pedro: Miller, 846.

Bahamas.

General: Vaughan, 1230

Baker.district, Oregon: Grant and Cady, 487.

Barite. See also Barytes.

Alaska, Wrangell: Burchard, 151, 153.

Kentucky, Georgetown quadrangle: Miller, 843.

Barytes. See also Barite.

Kentucky: Fohs, 430.

United States: Hill, 540.

Bathyliths. See Intrusions.

Batrachia. Sce Amphibia.

Batrachioides the antiquor: Kindle, 674 .

Battle Mountain district, Nevada: Bandmann, 34.

Bauxite.

Southern States: Phalen, 947

Tennessee: Purdue, 969.

United States: Phalen, 943.

Beaches. See also Shore lines; Terraces.

British Columbia, Victoria, Pleistocene: Newcombe, 873.

Ohio, Finger Lake bed: Hubbard, 587.

Quebec: Goldthwait, 470 .

Beaver Lake district, Saskatchewan: Bruce, 144.

Berea sandstone in eroded Cleveland shale: Burroughs, 160 .

\section{Bermuda Islands.}

General: Pirsson, 953.

Stratigraphic.

Boring: Pirsson, 953

Petrology.

Lavas: Pirsson, 954.

Bibliography.

Aluminum: Phalen, 943.

Arizona, Buckskin Mountains: Blanchard, 96.

Asbestos: Hopkins, 568 .

Bauxite: Phalen, 943.

Borax: Yale and Gale, 1351.

British Columbia, Field area: Allan, 5 .

California, ancient drainage system: Alling, 16

San Francisco district: Lawson, 724

Clinton iron ores: Earle, 380.

Color markíngs in Paleozoic fossils: Roundy, 1018.

Colorado: Jones, 631.

Economic geology, recent literature: Paige and Lloyd, 908; Paige and Katz, 907.

Economic minerals: Evans, 398.

Enrichment of ores: Clark, 237.

Eocene plants: Berry, 80 .

Eskers: Trowbridge, 1181 .

Fern ledges, St. John, New Brunswick: Stopes, 1150.

Fontaine, W. M., writings: Watson, 1262.

Graphite: Bastin, 59.

Iowa Pleistocene: Hay, 522

Iron ores: Earle, 380.

Lead and zinc, northwestern Illinois: Cox, 278.

Leidy, Joseph, writings: Osborn, 894.

Lockatong formation, 'Triassic: Hawkins, 520 .

Mammoth Cave: Hovey and Call, 580.

Manhattan schist, New York: Fettke, 420.

Marble: Dale, 300 .

Mexico: Thayer, 1164.

North America: Nickles, 876.

Nova Scotia, Arisaig-Antigonish district: Williams, 1300 .

Oolites: Brown, 141.

Petrology: Johannsen, 616.

Silliman, Benjamin, writings: Wright, 1339.

Slate: Dale et al., 302.

Talc: Hopkins, 568 .

T'exas, fuels: Phillips and Worrell, 950.

Triassic marine invertebrates: Smith, 1102.

Volcanism: Iddings, 606 .

Washington, coal: Daniels, 308

White, Charles A., writings: Dall, 303.

Wolframite: Hess and Schaller, 530.

Big Muddy dome, Wyo.: Barnett, 39.

\section{Biography.}

Barlow, A. E.: White, 1288.

Fontaine, W. M.: Watson, 1262

Leidy, Joseph: Osborn, 894.

Silliman, Benjamin: Wright, 1339.

Suess, Eduard: Hobbs, 549.

White, Charles A.: Dall, 303; Keyes, 663.

Winchell, N. H.: Clarke, 247; Schuchert, 1053.

Birds. See Aves.

Bismuth.

United States: Hess, 529 . 
Bituminous sands.

Alberta, northern: Ells, 387, 388.

\section{Bituminous shale.}

Colorado, northwestern: Woodruff and Day, 1334.

Utah, northeastern: Woodruff and Day, 1334.

Bivalves. See Pelecypoda.

Blowing wells. See Underground water.

\section{Borax.}

California, Saline Valley: Gale, 444.

Ventura County: Gale, 447.

United States: Yale and Gale, 1351.

\section{Borings.}

Bermuda Island: Pirsson, 953.

California, Death Valley: Gale, 443.

Canada, general: Ingall, 607.

Examination, methods of: Udden, 1200.

Illinois: Udden, 1200.

Bond, Macoupin, and Montgomery counties: Blatehley, 100.

Crawford and Lawrence counties: Blatchley, 98.

La Salle: Cady, 185.

Plymouth field: Blatchley, 99.

Sangamon County: Crook, 285.

Iowa, Bedford: Kay, 604.

Centerville: Kay, 638.

Kentucky: Hoeing, 554

Michigan: Smith, 1108.

Nevada, Columbus Marsh: Gale, 445.

New Mexico, Gallup Basin: Kirk, 682.

Oklahoma, Cushing field: Buttram, 178.

South Carolina, Charleston: Stephenson, 1128.

Texas, Coastal Plain: Deussen, 336.

Spur: Udden, 1202.

West Virginia, Kanawha County: White, 1286, 1287.

Botany, fossil. See Paleobotany.

Boulder batholith, Montana: Knopf, 688.

Boundary district, British Columbia: LeRoy, 738.

\section{Bowlders.}

Flattening by solution: Udden, 1201.

In gravel deposits: Rich, 993.

Bowling Green limestone: Savage, 1031.

\section{Brachiopoda.}

Cambrian: Burling, 158 .

Coloration: Greger, 496.

Mississippian, Mississippi Valley: Weller, 1270.

Parastrophia hemiplicata, plications: Wilson, 1311.

Plications, Parastrophia hemiplicata: Wilson, 1311.

Sedimentary relations, Cambrian and Ordovician: Burling, 158.

Syringothyris: North, 881 .

Triassic, marine: Smith, 1102.

\section{British Columbia.}

General: Burwash, 168.

Field area: Allan, 5 .

Graham Island, Queen Charlotte group: Clapp, 226.

Lillooet-Chilko Lake: Bateman, 61.

Princess Royal Island: McConnell, 782.

Texada Island: McConnell, 783.

Vancouver Island, Sooke area: Cooke, 276.

\section{British Columbla-Continued.}

Economic.

Alunite, Vancouver Island: Clapp, 229.

Babine Lake area, Omineca district: Emmens, 391.

Boundary district: LeRoy, 738.

Clay: Ries, 1003, 1004.

Clay and shale deposits: Ries and Keele, 1006.

Coal, Flathead Valley: Dowling, 365.

Galiano, Mayne, and Saturna islands: Clapp, 224.

East Kootenay district: Schofield, 1041.

Field area: Allan, 5.

Graham Island: MacKenzie, 793.

Groundhog anthracite field: Evans, 397; Malloch, 802 .

Hazelton: Malloch, 803.

Howe Sound, Britannia ore deposit: McConnell, 786.

Lillooet area: Bateman, 62 .

Mica, Big Bend district: De Schmid, 335.

Tête Jaune Cache district: De Schmid, 335.

Nanaimo area: Clapp, 225.

Observatory Inlet ore bodies: McConnell, 785.

Portland canal district: McConnell, 780.

Princess Royal Island: McConnell, 782.

Pyrophyllite, Vancouver Island: Clapp, 229.

Quadra Island: Cairnes, 191.

Rainy Hollow district: McConnell, 784.

Report, Bureau of Mines: Robertson, 1008.

Rossland district: Drysdale, 370 .

Similkameen district: Camsell, 199.

Skeena mining district: McConnell, 780.

Texada Island: McConnell, 779.

Thompson River valley: Drysdale, 369 .

Tulameen district: Camsell, 197.

Vancouver Island, Duncan area: Clapp and Cooke, 230.

Sooke area: Cooke, 276.

Yale district: Camsell, 198.

Dynamic and structural.

Glaciers: Ogilvie, 885 .

Pleistocene volcanism, Coast Range: Burwash, 167.

Physiographic.

Cheakamous region: Burwash, 167.

Field area: Allan, 5 .

Garibaldi volcanic area: Burwush, 169.

Pleistocene volcanoes of Coast Range: Burwash, 109.

Rocky Mountains: Fay, 410.

Thompson River valley: Drysdale, 369 .

Stratigraphic.

General: Burwash, 168.

Boundary district: Le Roy, 738.

Cambrian: Burling, 157.

East Kootenay: Schofield, 1039, 1041.

Field area: Allan, 5.

Fraser River valley: Bowen, 106.

Garibaldi volcanic area: Burwash, 169.

Geological map, Queen Charlotte Sound and Burke Channel: Graham, 484.

Golden-Banff: Allan, 6.

Graham Island: MacKenzie, 793.

Graham Island, Queen Charlotte group: Clapp, 226.

Groundhog coal field: Malloch, 802 .

Lillooet area: Bateman, 62 . 
British Columbia-Continued.

Stratigraphic-Continued.

Lillooet-Chilko Lake: Bateman, 61.

Moyie sills: Bailey, 28.

Nanaimo area: Clapp, 225.

Pleistocene beaches, Victoria: Newcombe, 873.

Portland canal district: McConnell, 780.

Pro-Cambrian, southeastern British Columbia: Schofield, 1043.

Prince Rupert-Aldermere: McConnell, 781.

Purcell Range: Scofield, 1042.

Quadra Island: Cairnes, 191.

Savona area: Rose, 1016.

Selkirk and Purcell Mountains: Daly, 300.

Skeena mining district: McConnell, 780.

Texada Island: McConnell, 779.

Thompson River valley: Drysdale, 369.

Tulameen district: Camsell, 197.

Vancouver Island, Duncan area: Clapp and Cooke, 230.

Kyuquot Sound: Clapp, 229.

Saanich area: Clapp, 223.

southern: Clapp, 227.

Victoria area: Clapp, 223.

Yale district: Camsell, 198.

Albertella fauna: Burling, 157.

Cretaceous invertebrates, Queen Charlotte Islands: Burwash, 166.

East Kootenay district, Pleistocene flora: Hollick, 561.

Petrology.

Field area: Allan, 5.

Moyie sills: Bailey, 28.

Purcell sills, East Kootenay: Schofield, 1042.

Tulameen district: Camsell, 197.

Underground water.

Vancouver Island, Sharp Point hot spring: Clapp, 228.

Broadtop coal field, Pennsylvania: Gardner, 452.

Brockocystis: Foerste, 429.

Broiliellus, Permian amphibian: Williston, 1307.

Brontotherium, restoration: Osborn, 897.

\section{Bryozoa.}

Cincinnatian: Cumings and Calloway, 295.

Indiana, Tanner's Creek: Cumings and Gallo. way, 295.

Building stone. See also Granite; Limestone; Sandstone; Stone.

Kentucky, Waverly formation: Morse and Foerste, 867.

New Brunswick: Parks, 920.

New Jersey, Raritan quadrangle: Bayley et al., 66.

Nova Scotia: Parks, 920.

Oregon: Parks, 919.

Quebec: Parks, 921.

Bully Hill District, California: Boyle, 113.

\section{Cadmium.}

United States: Siebenthal, 1087.

Cahuilia Basin, California: Blake, 25; Free, 438.

\section{California.}

General.

Imperial County: Merrill, 835.

Owens Basin: Gale, 449.

Panamint Valley: Gale, 449.

San Diego County: Merrill, 835.

Searles Lake: Gale, 449.

\section{Economic.}

Alleghany district: Ferguson, 417.

Auriferous gravel channels: Alling, 16.

Borate deposits, Ventura County: Gale,447.

Bully Hill district: Boyle, 113.

Celestite: Phalen, 942.

Chromic iron ore: Diller, 353.

Coal, Coalinga region: Pack and English, 903.

Copper deposits, Plumas County: Turner and Rogers, 1188.

Darwin silver-lead district, Inyo County: Knopf, 687.

Gold, Alleghany district: Ferguson, 417.

Weaverville quadrangle: Diller, 348 ; Ferguson, 416 .

Imperial County: Merrill, 835.

Inyo and White Mountains: Knopf, 686.

Magnesite: Gale, 448.

Marble, Barstow: Pack, 901.

Oil fields: Arnold and Garfias, 21.

anticlinal dome structure: Flager, 507.

faulting: Hager, 508.

unconformities and overlap: Hager, 509 .

Petroleum, Coalinga region: Pack and English, 903.

Quicksilver: Veatch, 1236.

Sonoma County: Palmer, 915.

Saline deposits, Death Valley: Gale, 443.

Saline Valley: Gale, 444.

Searles Lake: Dolbear, 357.

southeastern California: Gale, 449 .

San Diego County: Merrill, 835 .

San Francisco district: Lawson, 724.

Sierra County: Alling, 16.

Sodium sulphate, San Luis Obispo County: Gale, 446.

Dynamic and structural.

California fault line, erosion: Holway, 563 .

Earthquake, Santa Cruz Mountains, 1914: Beal, 67.

Earthquakes, registration at Berkeley: Davis, 318-321.

Lassen Peak: Wright, 1347.

eruptions: Boyce, 112; Diller, 349, 351; Holway, 565; Storms, 1151

San Bruno earthquake, 1914: Davis, 317.

Tufa deposits, Salton Sink: Jones, 628.

Physiographic.

Cahuilla Basin: Blake, 95.

Colorado Desert: Blake, 95 .

Glaciation, Coast Ranges: Holway, 566.

Salton Sea: MacDougạl et al., 791.

San Francisco Bay: Holway, 564.

San Francisco district: Lawson, 724.

Sierra Nevada Mountains: Alling, 16.

Yosemite Valley: Trench, 440; Matthes, 811. 
Callfornia-Continued.

Stratigraphic.

Barstow-Kramer region: Pack, 902.

Bully Hill district: Boyle, 113.

Cahuilla Basin: Free, 438.

Eocene: Arnold and Hannibal, 22.

Eocene horizons: Waring, 1254.

Fernando group, Newhall: Englişh, 393.

Ione formation, California: Dickerson, 346 .

Iivermore Valley: Branner, 116; Iawson, 720.

Martine zroup: Dickerson, 340.

Moraines, Yosemite: Matthes, 81.5.

Neocene, San Juan district: Anderson and Martin, 18.

Temblor Basin: Anderson and Martin, 18.

Orindan and Siestan formations: Merriam, 834 .

Pleistocene, Manix, Mohave Desert region: Buwalda, 181.

Rock Creek area, Mohave Desert: Dickerson, 342.

San Francisco district: Iawson, 724 .

San Joaquin Valley: Gester, 455.

Santa Ana Mountains: Dickerson, 341 .

Tejon group: Dickerson,.339.

Ventura County: Gale, 447.

Waltham, Priest, Bitterwater, and Peachtree valleys: Pack and English, 903.

Weaverville quadrangle: Ferguson, 416.

Palcontology.

Birds, Pleistocene, San Pedro: Miller, 846.

Brea maid: Merriam, 830 .

Cestraciont shark, Triassic: Bryant, 145.

Dolphin, San Louis Obispo County: Lull, 771.

Eocene Mollusca: Waring, 1254.

Faunal zones, Tejon group: Dickerson, 339.

Fernando group, Newhall: English, 393.

Gastropoda, Tertiary: Fnglish, 394.

Martinez fauna, Eocene: Dickerson, 340, 343.

Neocene, San Juan district; Anderson and Martin, 18.

Temblor Basin: Anderson and Martin, 18.

Neocene Mollusca: Martin, 807.

Orindan and Siestan faunas: Merriam, 834.

Oysters, Monterey series: Cruess, 292.

Pleistocene fauna, Hawver cave: Stock, 1145.

Pleistocene shells: Oldroyd, 887 .

Rancho I.a Brea: Stroner, 1153.

antelopes: Chandler, 216.

human remains: Merriam, 831 .

mylodont sloths: Stock, 1143, 1144.

San Pablo fauna: Clark, 233.

Tertiary echinoids, Carrizo Creek region, Colorado Desert: Kew, 653.

Triassic fauna: Smith, 1102.

Vertebrates, Hosselkns limestone: Bryant, 1.46. Petrology.

Bully Hill district: Boyle, 113 .

Copper deposits, Plumas County: Turner and

Mineralogy. Rogers, 118s.

Crestmore: Fakle, 378 .

Minerals: Eakle, 377.

Searlesite: Larsen and Hicks, 717.

Sulphohalite, Searles Lake: Gale and Hicks, 450.

Wilkeite and okenite: Eakle and Rogers, 379.

Underground Water.

Livermore Valley: Branner, 116; Lawson, 720.
Callixylon: F.lkins and Wieland, 386.

Camarasaurus: Mook, 858, 859 .

\section{Cambrian.}

Stratigraphy.

Alaska-Yukon boundary: Cairnes, 186, 187.

Arizona, Grand Canyon district: Noble, 890.

Mohave County, Grand Gulch region: Hill, 539.

British Columbia, East Kootenay district: Schofield, 1041.

Field area: Allan, 5 .

Selkirk and Purcell Mountains: Daly, 306.

California, Inyo and White Mountains: Knopf, 686.

Cape Breton Island: Matthew, 816.

Cordiliera: Burling, 157.

Massachusetts: Loughlin and Hechinger, 767.

Minnesota: Grout and Soper, 502.

Missouri, Rolla quadrangle: Lee, 727.

Montana, Dillon quadrangle: Winchell, 1319.

New Brunswick: Matthew, 816 .

St. John area: Hayes, 523 .

Newfoundland, Conception and Trinity bays: Van Ingen, 1222.

New Jersey, Raritan quadrangle: Bayley et al., 66.

New York, Saratoga Springs region: Cushing and Ruedemann, 296.

Ontario, Ottawa, ripple marks: Kindle, 681.

Pennsylvania, Coatesville quadrangle: Bliss and Jonas, 101.

Quebec, southern: Dresser, 367; Harvie, 515.

Texas, Van Horn quadrangle: Richardson, 999.

Upper Mississippi Valley: Walcott, 1244.

Vermont, Bennington: Gordon, 476.

Greensboro: Richardson and Turner, 996.

Hardwick: Richardson et al., 997.

Woodbury: Richardson et al., 997.

Virginia, Abingdon quadrangle: Stose, 1152.

Yukon, international boundary: Cairnes, 186. Paleontology.

Albertella fauna: Burling, 157.

Brachiopoda, sedimentary relations: Burling, 158.

Cape Breton Island: Matthew, 816.

Dikelocephalinæ: Walcott, 1244.

New Brunswick: Matthew, 816 .

Ozarkian seaweeds and oolites: Wieland, 1294.

Paradoxides, ontogeny: Raymond, 978.

Canada (general). See also names of provinces.

General:

Arctic region, Coppermine River region: Sandberg, 1027.

Borings, report: Ingall, 607 .

Summary report, Geological Survey, 1912 and 1913: Brock, 120, 121.

\section{Economic.}

Clay: Keete, 646.

Clay and shale deposits, western provinces: Ries, 1001, 1005.

Coal: Dick, 338.

Gypsum: Cole, 259.

Mineral resources: Fréchette, 437.

Mines Branch report, 1913: Haanal, 504.

Stratigraphic.

General: Burling, 159.

Borings: Ingall, 608. 
Canada-C̣ntinued.

Paleontology.

Invertebrate paleontology, report: Kindle, 678, 679 .

Paleobotany, report: Wilson, 1317, 1318.

Vertebrate paleontology, report: Lambe, 712, 713.

Mineralogy.

General: Johnston, 624, 625 .

Cannonball member of Lance formation: Lloyd, 759.

Cannonball River lignite field, North Dakota: Lloyd, 758.

\section{Carboniferous.}

Stratigraphy.

General.

Chester Group: Weller, 1269.

Classification: Keyes, 673 .

Correlation: Keyes, 661 .

Mississippian, Mississippi Valley: Weller, 1270.

Nomenclature: Keyes, 661.

Alaska, Hanagita-Bremner region: Moffit, 854.

Alaska-Yukon boundary: Cairnes, $186,187$.

Arizona, Grand Canyon district: Noble, $\mathbf{8 8 0}$.

Little Colorado Valley: Gregory, 497.

Mshave County, Grand Gulch region: Hill, 539.

Arkansas, Fort Smith-Poteau field: Smith, 1097.

British Columbia, East Kootenay: Schofierd, 1040.

Lillooet area: Bateman, 62 .

Lillooet-Chilko Lake: Bateman, 61.

Thompson River valley: Drysdale, 369 .

Vancouver Island, Duncan area: Clapp and Cooke, 230.

southern: Clapp, 227.

California, Alleghany district: Ferguson, 417.

Inyo and White Mountains: Knopf, 686.

Colorado, southwestern: Cross and Larsen, 280.

Idaho, Alder Creek district: Umpleby, 1209.

southeastem: Richards and Mansfield, 995.

Illinois, Bond, Macoupin, and Montgomery counties: Blatchley, 100.

Chester group: Weller, 1269.

Colchester and Macomb quadrangles: Hinds, 543.

Crawford and Lawrence counties: Blatchley, $9 \dot{8}$.

La Salle: Cady, 185.

Sangamon County: Crook, 285.

Iowa, Bethany limestone: Tilton, 1170.

Kentucky, Dawson Springs quadrangle: Crider, 283.

Earlington quadrangle: Crider, 284 .

Edmonson and Grayson counties: Bryant, 147.

Owensboro quadrangle: Crider, 281 ,

Pound quadrangle: Butts, 180.

Tell City quadrangle: Crider, 281.

Waverly formation: Morse and Foerste, 867.

Wayne County: Munn, 869 .

western: Hutchinson, 600 .

Massachusetts: Loughlin and Hechinger, 767.

Diamond Hill-Cumberland district: Warren and Powers, 1256.
Carboniferous-Continued.

Statigraphy-Continued.

Massachusetts: Squantum tillite: Sayles, 1034.

Michigan: .Cook, 273.

Wayne County: Sherzer, 1081.

Missouri, northeastern: Greene, 494.

Rolla quadrangle: Lee, 727.

Montana, Cleveland field: Bowen, 104.

Dillon quadrangle: Winchell, 1319.

Elliston field: Stone and Bonine, 1149

Nevada, Yellow Pine district: Hill, 538.

New Brunswick: Keele, 644.

St. John: Stopes, 1150.

New Mexico, Sierra Blanca field: Wegemann, 1268.

Nova Scotia: Hyde, 601.

Arisaig-Antigonish district: Williams, 1300.

Cape Breton Island, Clyburn Valley: Wright, 1350.

Joggins section: Bell, 77.

Strait of Canso: Hyde, 602.

Ohio, Waverly formation: Morse and Foerste, 867.

Oklahoma, Cushing field: Buttram, 178.

east-central: Snider, 1113.

Fort Smith-Poteau field: Smith, 1097.

Glenn field: Smith, 1098.

Grandfield district: Munn, $\mathbf{8 6 9}$.

northeastern: Snider, 1113.

Permian: Beede, 73.

Oregon, Baker district: Grant and Cady, 487.

Pennsylvania, Broadtop field: Gardner, 452.

Rhode Island: Loughlin and Hechinger, 767.

Diamond Hill-Cumberland district: Warren and Powers, 1256.

Tennessee, Perry County: Wade, 1239.

Waynesboro quadrangle: Drake, 366.

Texas: Udden, 1202.

Red beds: Case, 208.

Van Horn quadrangle: Richardson, 999

Utah, Canyon Range: Loughlin, 764.

Virginia, Abingdon quadrangle: Stose, 1152.

Pound quadrangle: Butts, 179, 180.

West Virginia, Kanawha County: Krebs and Teets, 697 .

Preston County: Hennen and Reger, 527.

Wyoming, Douglas field: Barnett, 41 .

Lincoln County: Schultz, 1058.

Yukon, international boundary: Cairnes, 186.

White River district: Cairnes, 190.

Paleontology.

Iowa, Burlington Crinoidea: Wood, 1326.

Kansas, Lawrence: Twenhofel and Dınbar, 1191.

Pennsylvanian vertebrates: Twenhofel, 1189.

Kentucky, Waverly plants: Scott and Jeffrey, 1061.

Mississippian Brachiopoda: Weller, 1270.

Nebraska, eurypterids: Barbour, 38.

jellyfish: Barbour, 37.

New Brunswick, St. John, flora: Stopes, 1150.

Plants, roof of Pittsburgh coal: Grier, 500 .

Texas: Udden, 1202.

Broiliellus: Williston, 1307.

West Virginia, Kanawha County: Price, 962.

Preston County: Price, 963. 


\section{Carnotite ores.}

Colorado: Hess, 528 .

Origin: Hess, 528 .

Pennsylvania, Mauch Chunk: Wherry, 1278.

Utah: Hess, 528; Howard, 581.

Cartography. See also Maps.

Geologic mapping: Paige, 905.

Castoroides, Madison County, N. Y.: Smith, 1094.

Catahoula sandstone, origin: Goldman, 468.

Cataract formation: Schuchert, 1054.

Caverns. See Caves.

Caves.

Arizona, Bisbee: Wilson, 1316.

Celestite.

California: Phalen, 942.

Cement and cement materials.

Southern States: Watson and Grasty, 1264.

United States: Burchard, 154.

Washington: Shedd, 1080.

Central America. See Costa Rica; Guatemala, etc.

Cephalopoda. See also Mollusca.

Acceleration of development: Smith, 1103.

Triassic, marine: Smith, 1102.

Cetacea. See Mammalia.

Chalicotheroidea, osteology: Holland and Peterson, 559.

Changes of level. See also Beaches; Shore lines; Terraces.

General: Johnson, 620.

Coastal subsidence: Davis, 316; Johnson, 619.

Connecticut Valley: Fairchild, 400.

Pleistocene submergence: Fairchild, 400.

Costa Rica; Talamanca region: MacDonald, 788 ; Miller, 845 .

Florida: Vaughan, 1232.

Hudson Valley, Pleistocene submergence: Fairchild, 400 .

Hudson-Champlain valley: Fairchild, 400 .

New Brunswick: Goldthwait, 473.

Ontario region, postglacial deformation: Spencer, 1118.

Chemical analyses. See list, $p, 142$.

Chert. See also Flint.

Missouri, Rolla quadrangle: Lee, 727.

Cheyenne River Indian Reservation, S. Dak.: Calvert et al., 193.

Chisana district, Alaska: Brooks, 123.

Chromic iron ore.

United States: Diller, 353.

Chromite.

Quebec, southern: Dresser, 367 .

Chronology, North America: Schuchert and Barrell, 1057 .

Circumcontinental growth: Chamberlin, 213.

\section{Classification.}

Igneous rocks: Tyrrell, 1193.

Ore deposits, gold-silver: Lindsley, 755 .

Sediments: Trowbridge, 1182.

Clastic sediments, mechanical composition: Udden, 1203.
Clay. See also Fire clay.

Gencral: Crider, 282.

Aluminum hydrates in clays: Edwards, 384; Ries, 1002.

Alberta: Ries, 1003, 1004; Ries and Keele, 1006. British Columbia: Ries, 1003, 1004: Ries and Keele, 1006.

Canada: Keele, 646.

western provinces: Ries, 1001, 1005.

Kentucky: Crider, 282; Easton, 382.

Minnesota: Grout and Soper, 502.

Montana, northeastern: Bauer, 63.

New Brunswick: Keele, 644 .

New York: Newland, 874.

North Dakota, south central: Leonard, 737.

Nova Scotia, Lunenburg County: Faribault, 404.

Quebec: Keele, 645 .

Saskatchewan: Ries and Keele, 1006.

Willowbunch area: Rose, 1017.

United States: U. S. G. S., 1216.

West Virginia, Kanawha County: Krebs and Teets, 697 .

Climate, geologic. See Paleoclimatology.

Clinton iron ores, genesis: Earle, 380.

Coal. See also Anthracite; Lignite.

General.

Accumulation of coal beds: Savage, 1032.

Analyses: Campbell, 195; Fieldner $c t$ al., 421.

Composition and qualities: Jeffrey, 613 .

Formation of coal beds: White and Thiessen, 1285.

Origin: Burroughs, 161: White and Thiessen, 1285.

Resins in coals of high rank: White, 1283.

Alaska: Crane, 279.

Bering River field: Fisher and Calvert, 422.

Cook Inlet and Kachemak Bay: Crane, 280.

Matanuska Valley: Martin and Mertie, 808.

Yakataga district: Maddren, 798.

Alberta, Jasper Park field: O'Neal, 891.

- North Saskatchewan River: Dowling, 363.

Smoky River field: O'Neal, 890.

South Fork district: MacKenzie, 792.

Arkansas, Sebastian County: Hackett, 505.

British Columbia, Flathead Valley: Dowling, 365.

Graham Island: Clapp, 226; MacKenzie, 793.

Groundhog field: Evans, 397; Malloch, 802.

Nanaimo area: Clapp, 225.

Tulameen district: Camsell, 197.

Canada: Dick, 338.

Colorado, Yampa field: Weston, 1275.

Idaho, Teton-Basin coal field, Horseshoe Creek district: Woodruff, 1331 .

Iowa, analyses: Hixson, 544 .

Kentucky: Hoeing, 556.

Bull Creek region: Hodge, 552.

Carr Fork field: Hodge, 552.

Dawson Springs quadrangle: Crider, 283.

Earlington quadrangle: Crider, 284.

Edmonson and Grayson counties: Bryant, 147.

Kentucky River, Perry and Knott counties: Hodge, 551. 
Coal-Continued.

Kentucky: Licking River, Magoffin County: Hodge, 550.

Owensboro quadrangle: Crider, 281.

Pound quadrangle: Butts, 180.

'Tell City quadrangle: Crider, 281. western: Hutchinson, 600.

Missouri, northeastern: Greene, 494.

Montana, Big Sandy field: Bowen, 105.

Cleveland ficld: Bowen, 104.

eastern: Palmer, 917.

Musselshell-Judith area: Bowen, 103.

Pine Ridge field: Rogers, 1012.

Western: Palmer, 916 .

New Mexico, Gallup Basin: Kirk, 682.

Sierra Blanca field: Wegemann, 1269.

North Carolina; Dan River field: Stone, 1146.

North Dakota, Cannonball River lignite field: lloyd, 758.

Ohio, Hocking Valley field: Burroughs, 162.

Oregon, Eden Rilge field: I.esher, 739 .

Joln Day region: Collier, 266.

southwestern: Diller, 352.

Squaw Creek Basin, Coos County: Williams, 1298.

Pennsylvania: Burrows, 163.

Brondtop field: Gardner, 452 .

Pittsburgh bed: Burroughs, 163 .

Pocono conls: Halberstadt, 51.0 .

Saskatchewan, Willowbunch area: Rose, 1017.

Texas: Phillips and Worrell, 950.

United States: U. S. G. S., 1216.

Utah, Book Cliffs field: Lewis, 748 .

Grand County, Thompson: C.lark, 235.

Wales, Sanpete County: Clark, 236.

Virginia, Pound quadrangle: Butts, $179,180$.

Powell Mountain, Scott Connty: Camphell, 194.

Washington, Glacier field: Woodrufr, 1332.

Issaquah field: Fvans, 398 .

Pierce County: Daniels, $30 \mathrm{~s}$

West Virginia, Kanawha County: Krels and Teets, 697 .

Preston County: Hennen ard Reger, 527.

Wyoming, Tincoln County: Schultz, ]nss.

Yukon: Payne, 925.

Coal Measures. Sce Carboniferous.

\section{Coast changes.}

New Jersey: Johnson and Smith, 623.

Coastal stability: Johnson, 619.

Coatesville quadrangle, Pennsylvania: Bliss and Jonas, 101.

Cobalt.

United States: Fress, 529.

\section{Colorado.}

General.

Bibliography: Jones, 631 .

Economic.

Bituminous shale: Woodruff and Day, 1333.

Carnotite deposits, origin: Hess, $52 \mathrm{~S}$.

Cerusite, Custer County: Hunter, 596.

De Beque, Mesa County, petroleum field: De Beque, 331 .

Gilpin County ore bodies, origin: Becker, 68 .

Granite, Gunnison: Hunter, 595.
Colorado-Continued.

Economic-Continued.

Iron, Caribou: Bastin, 58 .

Lead, Custer County: Hunter, 596.

Leadville: Argall, 20.

Oil shale, northwestern Colorado: Woodruff and Day, 1333.

Pitchblende ores, Gilpin County: Bastin, 57 .

Radium: Parsons, 922.

Silver Lake basin: Prosser, 965.

Unaweep copper district, Mesa County: Butler, 171.

Yampa coal field, Routt County: Weston, 1275.

Physiographie.

San Juan Mountains: Atwond, 25.

Stratigraphic.

Ceneral: Henderson, 525.

Geologic map: George, 454.

Southwestern Colorado: Cross and Larsen, 290, 291.

\section{Paleontology.}

General: Henderson, 525 .

Camarasaurus: Mook, 858 .

Dinosauria: Gilmore, 460.

Florissant insects: Cockerell, 256.

Bombyliida: Cockerell, 250.

Coleoptera: Wickham, 1292.

Diptera: Cockerell, 254.

Orthoptera: Cockerell, 252.

sawfly: Cockrell, 253.

Smilax, Florissant: Cockerell, 255.

Petrology.

A pishapa quadrangle: Cross, 288.

Eocene formations, Rocky Mountains, petrographic characters: Johannse?, 615.

Mineralogy.

Cebollite, Gunnison Connty: Tarsen and Schaller, 719.

Chalcophanite, Leadville: Ford, 433.

Empressite: Bradley, 114.

Ferberite: Hess and Schaller, 530 .

Gunnison County: Larsen and Hunter, 718.

Hetærolite, Leadville: Argall, 19.

Metahewettite: Hillebrand et al., 541 .

Meteorites, BishopCanyon, San Miguel County: Farrington, 409.

Muthmannite: Schaller, 1036.

Columnar structure in limestione: Kindle, 675.

\section{Concrete materials.}

Iowa: Beyer and Wright, 90.

\section{Concretions.}

Oolitic and pisolitic barite, Sarntoga oil field, Texas: Moore, 862.

\section{Conglomerates.}

Corrosion conglomerate: Sardeson, 1030.

Intraformational conglomerate: Sardeson, 1030.

Ohio, Mississippian: Lamb, 70 .

Congresses. See Associations.

\section{Connecticut.}

Physiographic.

Cheshire "dam:" Ward, 1253.

Paleontology.

Mastodon: Schuchert, 1052.

Farmington: Lull, 772. 
Contact phenomena.

Idaho, Mackay: Umpleby, 1209.

New York, North Creek quadrangle: Miller, 850 .

Recrystallization of limestone: Leith, 734 .

Silicate zones, secondary: Kemp, 652; Higgins, 536; Lindgren, 752; Stewart, 1140; Uglow, 1206.

Contemporaneous deformation: Lahee, 704.

Continental forms, origin: Baker, 29.

\section{Copper.}

General.

Copper-ore enrichment, chemistry of: Clark, 237.

Enrichment of sulphide ores: Clark, 237.

Genesis of deposits: Tolman and Clark, 1176.

Pyrrhotite, relation to chalcopyrite and other sulphides: Thompson, 1167.

Sulphide enrichment: Rogers, 1010.

Alaska: Brooks, 124.

Chisana district: Brooks, 123.

Hanagita-Bremner region: Moffit, 854 .

Ketchikan region: Smith, 1106.

Matanuska Valley: Martin and Mertie, 808.

Prince William Sound: Johnson, 617.

Arizona, Ajo district: Joralemon, 634.

Bisbee district: Notman, 882; Tenney, 1163.

Copper Creek district: Hafer, 506.

Globe district: Tovote, 1178 .

Mohave County, Grand Gulch region: Hill, 539.

Patagonia district: Probert, 964.

Superior: Ransome, 973.

White Mesa district: Hill, 537.

British Columbia, Boundary district: LeRoy, 738.

Quadra Island: Cairnes, 191.

Texada Island: McConnell, 779.

Tulameen district: Camsell, 197.

Vancouver Island, Duncan area: Clapp and Cooke, 230.

southern: Clapp, 227.

Yale district: Camsell, 198.

California, Bully Hill district: Boyle, i13.

Inyo and White Mountains: Knopf, 686.

Plumas County: Turner and Rogers, 1188.

Central States: Butler and Dunlop, 175.

Colorado, Unaweep district: Butler, 171.

Eastern States: McCaskey, 776.

Idaho, Mackay: Umpleby, 1208, 1209, 1212.

Mullan: Calkins and Jones, 192.

Maryland, New London mine, Frederick County: Butler and McCaskey, 176.

Michigan: Hore, 573.

Montana, Butte district: Ray, 977.

Dillon quadrangle: Winchell, 1319.

Park County: Gardner, 451.

Saltese: Calkins and Jones, 192.

Nevada, Ely: Whitman, 1290.

Yellow Pine district: Hill, 538.

New Jersey, Raritan quadrangle: Bayley et al., 66.

New Mexico, Apache district: Wade, 1240.

Burro Mountain district: Bush, 170.

Organ Mountain district: Welsh, 1274.

Pinos Altos district: Wade, 1241.

Northwest Territories, Coppermine River: Sandberg, 1027.
Copper-Continued.

Oregon, northeastern: Swartley, 1155 .

southwestern: Diller, 352 .

Pennsylvania, South Mountain region: Bevier, 89.

Quebec: Bancroft, 33 .

Southern States: Gordon, 478.

United States: Butler, 173.

Utah, San Francisco district: Butler, 172.

Washington, northeastern: Bancroft, 31 .

Copper Creek district, Ariz.: Hafer, 506.

Coppermine River region, Canada: Douglas, 359, Sandberg, 1027.

\section{Coral reefs and islands.}

General: Davis, 323; Pirsson, 953; Vaughan; $1231,1233$.

Barrier reefs, platforms: Vaughan, 1234.

Florida coral reef tract: Vaughan, 1232.

Origin: Davis, 323 .

Corals. See Anthozoa.

Correlation. See Stratigraphic.

Corythosaurus, Alberta: Brown, 136.

Costa Rica.

General.

Sixaola River region: MacDonald, 788; Miller, 845.

Talamanca region: MacDonald, 788; Miller, 845 . Dynamic and structural.

Volcano, Miravalles: Peralta, 929; 'Tristán, 1179.

Stratigraphic.

Sedimentary formations: Alfaro, 4.

Sixaola River region: MacDonald, 788; Miller, 845.

Talamanca region: MacDonald, 788; Miller, 845. Craigton Lake, tilted shore lines: Hubbard, 586.

\section{Cretaceous.}

Stratigraphy.

General.

Cannonball member of Lance formation: Lloyd, 759.

Cretaceous-Eocene contact, Atlantic and Gulf Coastal Plain: Stephenson, 1130.

Cretaceous-Tertiary boundary: Brown, 133; Knowlton, 692; Matthew, 819; Osborn, 895; Stanton, 1122.

Montana group: Stebinger, 1126

Alaska, Iditarod Ruby region: Eakin, 373.

Alberta, Crowsnest volcanics: MacKenzie, 794.

Sheep River field: Dowling, 362, 364.

South Fork district: MacKenzie, 792.

British Columbia, Fraser River valley: Bowen, 106.

Galiano, Mayne, and Saturna islands: Clapp, 224.

Graham Island: Clapp, 226; MacKenzie, 793.

Groundhog coal field: Malloch, 802.

Lillooet-Chilko Lake: Bateman, 61.

Nanaimo area: Clapp, 225.

Prince Rupert-Aldermere: McConnell, 781.

Quadra Island: Cairnes, 191.

Texada Island: McConnell, 779.

Thompson River valley: Drysdale, 369 .

Tulameen district: Camsell, 197.

Vancouver Island: Clapp, 223.

Duncan area: Clapp and Cooke, 230. 
Cretaceous-Continued.

Stratigraphy-Continued.

California, Coalinga region: Pack and English, 903.

San Francisco district: Lawson, 724

Santa Ana Mountains: Dickerson, 341.

Georgia: Berry, 80.

Gulf region, enstern, and Carolinas: Stephenson, 1128 .

Idaho, southeastern: Richards and Mansfield, 995.

Minnesota: Grout and Soper, 502.

Montana, Big Sandy field: Bowen, 105.

Blackfeet Reservation: Stebinger, 1124.

Cleveland field: Bowen, 104.

Dillon quadrangle: Winchell, 1319.

Musselshell-Judith area: Bowen, 103.

northwestern: Stebinger, 1125.

New Mexico, Gallup Basin: Kirk, 682.

Sierra Blanca field: Wegemann, 1268.

western: W inchester, 1324

New York, Long Island: Fuller, 441.

North Dakota, Cannonball River lignito field: Lloyd, 758.

south central: Leonard, 737 .

Oregon, southwestern: Diller, 352; Winchell, 1320.

Rocky Mountain regjion: Lee, 728 .

South Carolina: Berry, 80.

Charleston: Stephenson, 1128.

South Dakota, Cheyenne River Indian Reservation: Calvert et al., 193.

Standing Rock Indian Reservation: Calvert et al., 193.

Tennessee, Perry County: Wade, 1239.

Waynesboro quadrangle: Drake, 366 .

Texas, Van Horn quadrangle: Richards on, 999.

Utah, Green River field: Lupton, 773.

Wyoming, Big Muddy dome: Barnett, 39.

Douglas field: Barnett, 41 :

Lincoln County: Schultz, 1058 .

Moorcroft field: Barnett, 40.

Salt Creek field: Trumbull, 1186.

Shoshone River section: Hewett, 534.

Paleontology.

Alberta, Dinosauria, Belly River formation: Lambe, 708.

Anchiceratops, Alberta: Brown, 134.

Corythosaurus, Alberta: Brown, 136 .

Dinosauria, Alberta: Lambe, 706, 707.

Exogyra: Stephenson, 1128.

Georgia flora: Berry, 80 .

Gulf region, eastern, and Carol inas: Stephenson, 1128.

Ichthyosaurian, Benton: Gilmore, 461.

Leptoceratops, Alberta: Brown, 177.

Maryland, floras: Berry, 84.

Monoclonius, Alberta: Brown, 135.

Montana, dinosaur: Gilmore, 462.

South Carolina flora: Berry, 80.

Crinoid skeletons, composition: Clarkeand Wheeler, 241.

Crinoidea. See also Echinodermata.

Arms in phylogeny: Wood, 1326.

Cactocrinus: Wood, 1326.

Crinoid skeletons, composition: Clarke and Wheeler, 241.
Crinoldea-Continued.

Homocrinus: Kirk, 683.

Phylogenetic studies: Wood, 1326 .

Quebec, Grand Greve, Devonian: Clarke, 244.

Crowsnest volcanics: MacKenzie, 794.

Cryptogams. See Paleobotany.

Cryptophragmus: Raymond, 983.

Cryptozoon: Wieland, 1294.

Crystallography.

Ferberite: Hess and Schaller, 530.

Textbook: Walker, 1247.

Willemite: Palache and Graham, 910.

Cuba. Sce also West Indies.

Economic.

Iron: Woodbridge, 1329

Paleontology.

Mammalia: Matthew, 822 .

Cycads: Wieland, 1295.

Cystoidea.

Agelacrinidæ: Foerste, 429.

Jepadocystinæ: Foerste, 429.

Daubrée experiment and capillarity: Johnston and Adams, 623.

Dawson Springs quadrangle, Kentucky: Crider, 283.

Decomposition of rocks. See Weathering.

Deep-sea deposits: Chamberlin, 211.

Definitions, See Nomenclature.

Deformation.

Contemporaneous deformation: lahee, 704 .

Deltas.

General: Shaw, 1079 .

Mississippi River: Shaw, 1078, 1079.

Upper Devonian delta, Appalachian geosyncline: Barrell, 50.

Denudation. Sce also Erosion.

General: Keyes, 669 .

Rate: Chamberlin, 213.

Depew quadrangle, N. Y.: Luther, 775.

Deposition of ores. Sec Ore deposits, origin.

Deposition. Sce also Sedimentation.

Tufa deposits, Salton Sink: Jones, 628.

Desert basins: Free, 439 .

Devonian.

Stratigraphy.

Alaska, international boundary: Cairnes, 186 , 187.

Appalachian region: Barrell, 50.

British Columbia, East Kootenay: Schofield, 1040, 1041.

California, Inyo and White Mountains: Knopf, 686 .

Colorado, southwestern: Cross and Larsen, 290.

Illinois, Rock Island region: Ekblaw, 385.

Iowa: Keyes, 657.

Kentucky, Pound quadrangle: Butts, 180.

Wayne County: Munn, 869 .

Maine, Eastport quadrangle: Bastin and Williams, 60 .

Parlin Stream: Pirsson and Schuchert, 955.

Somerset County: Clarke, 244.

Manitoba: Kindle, 676; MacLean and Wallace, 796. 
Devonian-Continued.

Stratigraphy-Continued.

Michigan: Cook, 273.

Wayne County: Sherzer, 1081.

Minnesota: Grout and Soper, 502.

Montana, Dillon quadrangle: Winchell, 1319.

New Brunswick, Dalhousie: Clarke, 244.

New Jersey, Raritan quadrangle: Bayley ct al., 66.

New York, $\Lambda$ ttica-Depew quadrangles: Luther, 775.

Erie County: Houghton, 577.

southeastern: Clarke, 244.

Syracuse quadrangle: Hopkins, 571.

Nova Scotia, Arisaig-Antigonish district: Williams, 1300 .

Ontario, Oriskany sandstone and Ohio shale: Kindle, 677 .

Thedford: Williams, 1302.

Quebec, southern: Harvie, 515 .

Tennessee, Perry County: Wade, 1239.

Waynesboro quadrangle: Drake, 366 .

Virginia, $A$ bingdon quadrangle: Stose, 1152.

West Virginia, Preston County: Hennen and Reger, 527 .

Yukon, international boundary: Cairnes, 186.

\section{Paleontology.}

Arctic: Schuchert, 1055.

Illinois, Rock Island region: Ekblaw, 385 .

Maine, Chapman fauna: Clarke, 244.

Moose River fauna: Clarke, 244.

Parlin Stream: Pirsson and Schuchert, 955.

Michigan, Dundee limestone fauna: Grabau, 482.

Missouri, fishes: Branson, 118.

New Brunswick, Dalhousie fauna: Clarke, 244

New York, Port Ewen fauna: Clarke, 244.

Pennsylvania, Rectogloma: Van Tuyl and Berckhemer, 1227.

Diadectes: Broom, 126.

Diamond Hill-Cumberland district, Rhode IslandMassachusetts: Warren and Powers, 1256.

\section{Diamonds.}

Arkansas: Miser, $\mathbf{8 5 3 .}$

British Columbia, Tulameen district: Camsell, 197.

\section{Diastrophism.}

Gencral: Chamberlin, 209.

Deep-sea deposits: Chamberlin, 210.

Foreset beds and slope deposits: Chamberlin, 212.

Paleozoic shelf seas: Chamberlin, 210 .

Shelf seas: Chamberlin, 210.

\section{Dilkes.}

Colorado, A pishapa quadrangle: Cross, 288.

New Jersey, Raritan quadrangle: Bayley ct al. ., 66.

New York, Syracuse, peridotite: Clark, 234.

Quebec, St. Hilaire and Rougemont mountains: O'Neill, 892.

Dinosauria. See Reptilia.

Dip chart: Bancroft, 32; Linforth, 756; Simons, 1089.

Diploceras, Uinta Eocene: Peterson, 935.
Dolichorhinus, Uinta beds: Peterson, 939.

Dislocations. See Faulting.

Distribution. See Geographic distribution.

\section{Dolomite.}

Iowa: Knight, 684.

Origin: Dale, 300; Farrington, 40s; Van Tuyl, 1225.

Dolomitization: Walcott, 1246; Wallace, 1250.

\section{Drainage changes.}

California, Sierra Nevada: Alling, 16.

Connecticut, Cheshire: Ward, 1253.

Iowa: Lees, 729.

Ohio: Coffey, 258.

southwestern: Fenneman, 411.

Pennsylvania, Susquehanna River: Darton, 309.

Drift deposits. See also Glacial geology. Iowa, Cedar Rapids region: Shipton, 1085.

Des Moines- $\Lambda$ llerton section: Tilton, 1171.

Kansas, Topeka: Wooster, 1337.

Nebraska, Kansan drift: Barbour, 36.

New York, Long Island: Fuller, 441.

Nova Scotia: Goldthwait, 471.

Precious stones in drift: Muilenburg, 868 .

Quebec, Montreal region: Stansfield, 1120.

Drumlins.

New York, east central: Rich, 991.

Dynamic and structural (general). For regional, see the various States. See also list of subject headings on $p .97$.

General: Iddings, 603.

Arcuate mountains, formation of: Hobbs, 546. Boulders in gravel deposits: Tiich, 993.

Catahoula sandstone, origin: Goldman, 468.

Clastic sediments, mechanical composition: Udden, 1203.

Daubrée experiment and capillarity: Johnston and Adams, 623 .

Deformations, periodic: Chamberlin, 209.

Exfoliation, concave: Matthes, 814 .

Fracture systems, spacing: Scott, 1062.

Fracturing of rocks: Becker, 72 .

Geologic processes, syllabus: Keyes, 665.

Gypsum and anhydrite: Wallace, 1252.

Interference ripples: Kindle, 674 .

Migration of poles: Barrell, 51.

Parting in coal bed: Rogers, 1014.

Ripple marks: Epry, 396.

Segmentation of earth: Chamberlin, 214.

Stream valleys: $\mathrm{Rich}, 992$.

Transportation of débris by running water: Gilbert, 458.

Earlington quadrangle, Kentucky: Crider, $2 \$ 4$.

Earth, age, from evolution: Matthew, 817.

Earth's crust: Holland, 558; Barrell, 46, 48, 49.

Earth, genesis of. See also Dynamic and structural (general).

Segmentation of earth: Chamberlin, 214.

\section{Earth, interior.}

General: Iddings, 603.

Earth, shape: Bowie, 110.

Earthquake sea waves: Reid, 990. 
Earthquakes. Sec also Seismology. California, registration at Berkeley: Davis, 318-321.

San Bruno: Davis, 317.

Santa Cruz Mountains: Beal, 67.

Hawaii, 1868: Wood, 1328.

Illinois, January 2, 1912: Udden, 1199.

Magnets, suspended, effects on: Reid, 988.

Panama, Los Santos: MacDonald and Johnston, 789.

South Carolina, Charleston: Taber, 1156.

Tennessee, east: Gordon, 477 .

Eastport quadrangle, Maine: Bastin and Williams, 60 .

Echinoidea.

California, Tertiary: Kew, 653.

Economic (general). For regional see under the various States. See also Ore deposits, origin, and the particular products.

Boulder batholith, origin: Knopf, 688 .

Gypsum and anhydrite: Wallace, 1252.

Recrystallization of limestone: Ieith, 734 .

Relation of geology to mining: Hatch, 516.

Silicate zones, secondary: Kemp, 652; Leith, 734; Stewart, 1140; Jindgren, 752; Uglow 1206.

Useful minerals of the United States: Sanford and Stone, 102 s.

Educational. Sec also Toxtbooks.

Interpretation of topographic maps: Salisbury and Trowbridge, 1023.

Laboratory exercises in structural and historical gcology: Salisbury and Trowbridge, 1024.

Studies in geology: Salisbury and Trowbridge, 1025.

Syllabus of lectures on geologic processes: Keyes, 665 .

Electric activity in ore deposits: Wells, 1273.

Elevation and subsidence. See Changes of level.

Eocene. Sce Tertiary.

Eolation. Sec Wind work.

Eolian action. See Wind work.

Eotitanops, restoration: Osborn, 897.

Erosion. Sec also Sedimentation; Glacial erosion.

California fault line: Holway, 563 .

Chesapeake Bay, mouth of Choptank River: Hunter, 597.

Coast changes, New Jersey: Johnson and Smith, 623 .

Hillside wash: Purdue, 968.

Missouri, southeastern: Dake, 298.

Ohio, Fayette County: Napper, 871 .

Stream crosion in deserts: Keyes, 670.

Stream valleys: $R i c h, 992$.

Eruptive rocks. See Igneous and volcanic rocks.

Eskers.

Ohio, Locust Grove: Thompson, 1168.

Origin: Millis, 852; Trowbridge, 1181.

Essays. See Addresses.

\section{Eurypterida.}

Nebraska, Carboniferous: Barbour, 38.
Evolution.

General: Osborn, 899

Cephalopoda: Smith, 1103.

Convergent evolution: Gregory et al., 499.

Evolution, time ratios: Matthew, 817.

Excursions.

International Geological Congress: Moore, 861.

Exfoliation, concave: Matthes, 814.

Experimental investigations.

General: Paulcke, 924

Faulting.

Faultfinder: Simons, 1088; Weeks and Hunt ington, 1267

Idaho, Bannock overthrust: Richards and Mansfield, 995.

Landslide fault: Smith and Zulch, 1110.

Maine, Eastport quadrangle: Bastin and Williams, 60 .

New Mexico, Luna County: 1)arton, 312.

New York, North Creek quadrangle: Miller, 850.

Saratoga Springs region: Cushing and Ruedomann, 296.

Nomenelature: Stevens, 1137.

Feldspar.

New York: Newland, 874.

United States: Katz, 636 .

Ferberite: Hess and Schaller, 530.

Fernando group, Newhall, California: English, 393.

Field area, British Columbia: Allan, 5 .

Fire clay.

Kentucky: Crider, 282.

Fishes. Sce Pisces.

Fissures. Sce Faulting.

Florida.

General.

Survey report: Sellards, 10 tit.

Economic.

Mineral resources: Sellards, 1067.

Phosphate: Sellards, 1067, 1070.

Physiographic.

Coral reef areas: Vaughan, 1232.

Lakes: Sellards, 1068, 1073.

Stratigraphic.

General: Vaughan, 1232.

Alachua clays: Sellards, 1069.

Hawthorn formation: Vaughan and Cooke, 1235.

Paleontology.

Neocene Molluscit: Olsson, 889 .

Underground water.

General: Sellards, 10 tis.

Florida coral reef tract: Vaughan, 1232.

Florida Mountains, N. Mex.: Becker, 69.

Florida reef tract, geologic history: Vaughan, 1231.

Fluorspar.

United States: Burchard, 154.

Folding.

General: Hobbs, 546 .

Arcuate mountains, formation of: Hobbs, 546. 
Forests, fossil.

Montana, Galldtin Mts.: Knowlton, 693.

Fossils. See Paleontology.

Fracture systems, spacing: Scott, 1062.

Frigites: Barbour, 36.

Frogs: Moodie, 857.

Fuller's earth.

General: Parsons, 923.

Southern States: Sellards, 1072.

Fusulina, nomenclature: Girty, 463.

Garnet.

New York, North Creek quadrangle: Miller, 850.

Garnet zones, origin: Lindgren, 752.

Gas. See Natural gas.

Castropoda. See also Mollusca.

Antigua, Oligocene: Brown and Pilsbry, 132.

California, Tertiary: English, 394.

Color markings: Roundy, 1018.

Hercynella: O'Connell, 884.

Massachusetts, Vitrinella: Clapp, 231.

New York, Silurian: O'Connell, 884.

Wyoming, Tertiary: Cockerell, 251.

Gems. See also Precious stones.

United States: Sterrett, 1135.

Genesis of ores. See Ore deposits, origin.

Geochemistry.

General: Nishihara, 879 .

Binary system $\mathrm{MgO}-\mathrm{SiO}_{2}$ : Bowen and Andersen, 109.

Yopper-ore enrichment, chemistry of: Clark, 237.

Copper sulphide ores, enrichment: Clark, 237.

Dolomitization: Wallacc, $\mathbf{1 2 5 0 .}$

Marcasite and wurtzite: Allen and Crenshaw, 8.

Metallic elements, relative abundance: Clarke and Steiger, 240.

Mineral analyses, calculation and comparison: Van Orstrand and Wright, 1224.

Pyrite and marcasite: Allen and Crenshaw, 7. Silicates, constitution: Clarke, 238.

Silver enrichment: Palmer, 913.

Geodes.

Origin: Van Tuyl, 1226.

Gengenesis. See Earth, genesis of.

Geographic distribution.

Eocene flora, southeastern North America: Berry, 86.

Geologic chronology for North America: Schuchert and Barrell, 1057.

Geologic climate. See Paleoclimatology.

Geologic formations described. See list, p. 145 .

Tables. See Stratigraphic, Tables of formations.

Geologic history. See also Puleoclimatology and Páleogrography.

General: Keyes, 660; Schuchert, 1051.

Alaska, Hanagita-Bremner region: Moffit, 854.

Iditarod-Ruby region: Eakin, 373.

Appalachian region: Barrell, 50.

Arizona, Buckskin Mountains: Blanchard, 96. Grand Canyon district: Noble, 880 .
Geologic history-Continued.

British Columbia, Field area: Allan, 5.

Groundhog coal field: Malloch, 802 .

Nanaimo area: Clapp, 225.

Texada Island: McConnell, 779.

Thompson River valley: Drysdale, 369 .

Tulameen district: Camsell, 197.

Vancouver Island: Clapp, 223.

California, Cahuilla Basin: Free, 438.

San Francisco district: Lawson, 724.

Santa Ana Mountains: Dickerson, 341 .

Temblor Basin: Anderson and Martin, 18.

Weaverville quadrangle: Diller, 348 .

Cape Breton Island: Matthew, 816.

Costa Rica, Talamanca region: MacDonald, 788; Miller, 845.

Cretaceous, South Carolina: Berry, 80.

Florida: Vaughan, 1232.

Florida reef tract: Vaughan, $123 i$.

Kansas: Wooster, 1338.

Lake Lahontan: Jones, 629.

Maine, Eastport quadrangle: Bastin and Williams, 60 .

Massachusetts, Diamond Hill-Cumberland district: Warren and Powers, 1256.

Missouri River, Pleistocene history: Todd, 1173.

Nevada, Lake Lahontan: Jones, 629.

Nevada, west central: Buwalda, 183.

New Brunswick: Matthew, 816 .

New Jersey, Raritan quadrangle: Bayley et al., 66.

Neł Mexico, Gallup Basin: Kirk, 682.

New York: Miller, 849.

Erie County: Houghton, 577.

Long Island: Fuller, 441.

New York City: Berkey and Healy, 79.

North Creek quadrangle: Miller, 850 .

Saratoga Springs region: Cushing and Ruedemann, 296.

North Carolina, Chapel Hill: Smith, 1104.

North Dakota, south central: Leonard, 737.

Nova Scotia, Arisaig-Antigonish district: Williams, 1300.

Joggins section: Bell, 77 .

Ontario, Rainy Lake: Lawson, 721.

Oregon, Sumpter quadrangle, Pardee and Hewett, 918 .

Pennsylvania, Coatesville quadrangle: Bliss and Jonas, 101

Quebec, Kewagama Lake area: Wilson, 1313. southern: Dresser, 367 .

Rhode Island, Diamond Hill-Cumberland district: Warren and Powers, 1256.

South Carolina: Rogers, 1013.

Tennessee, Perry County: Wade, 1239.

Texas, Van Horn quadrangle: Richardson, 999.

Utah, Canyon Range: Loughlin, 764.

Vermont, western: Dale, 300 .

Washington, northeastern: Bancroft, 31 .

Wyoming, central western: Blackwelder, 93 .

Geologic map of the world: Margerie, 806 .

Geologic maps.

Alaska, Bering River field: Fisher and Calvert, 422.

Broad Pass region: Moffit, 855. 
Geologic maps-Continued.

Alaska, glaciers: Tarr and Martin, 1157.

Hanagita-Bremner region: Moffit, 854:

Iditarod-Ruby region: Eakin, 373.

international boundary: Cairnes, 185.

Juneau, Skagway, and Sitka districts: Burchard, 152.

mineral resources: Brooks, 122 .

Willow Creek district: Capps, 202.

Yukon-Koyukuk region: Eakin, 375.

Alberta, Blairmore area: MacKenzie, 792.

Sheep River feld: Dowling, 362 .

Arctic regions, Ellesmere Land: Holtedahl, 562.

Arizona, Shinumo quadrangle: Noble, $\mathbf{8 8 0}$.

Yuma County: Blanchard, 96.

Arkansas, Fort Smith-Poteau field: Smith, 1097.

British Columbia, Boundary district (part): LeRoy, 738.

Cranbrook area: Schofield, 1040.

Field area: Allan, 5 .

Galiano, Mayne, and Saturna islands: Clapp,

Garibaldi Lak $\theta$ volcanic area: Burwash, 167, 169.

Graham Island: Clapp, 226.

Groundhog coal field: Malloch, 802.

Nanaimo area: Clapp, 225.

Portland canal district: McConnell, $\mathbf{7 8 0 .}$

Queen Charlotte Sound and Burke Channel: Graham, 484.

Texada Island: McConnell, 779.

Thompson River valley: Drysdale, 369 .

Tulameen district: Camsell, 197.

California, Alleghany district: Ferguson, 417.

Barstow-Kramer region: Pack, 902.

Coalinga region: Pack and English, 903.

Colorado Desert: Kew, 653.

Lake County: Dickerson, 340 .

Livermore Valley: Branner, 116.

Placerville slate district: Dale ct al., 302.

Rock Creek quadrangle: Dickerson, 342 .

San Francisco district: Lawson, 724.

San Juan district: Anderson and Martin, 18

Santa Ana Mountains: Dickerson, 341.

Temblor Basin: Anderson and Martin, 18.

Weavervillequadrangle: Diller,348; Ferguson, 410.

Colorado: George, 454.

Coppermine River region: Sandberg, 1027.

Cretaceous, eastern Gulf ${ }^{\circ}$ region: Stephenson, 1128.

Georgia, northern: Hopkins, 568 .

Idaho, Alder Creek district: Umpleby, 1209.

Mullan: Calkins and Jones, 192.

Sawtooth quadrangle: Umpleby, 1210.

southeastern: Richards and Mausfield, 995.

Illinois, Galena and Elizabeth quadrangles: Cox, 278

oil fields: Blatchley, 98 .

Iowa: Kay, 640.

Kansas: Haworth, 520 .

Kentucky, Calhoun quadrangle: Hutchinson, 600 .

Central City quadrangle: Hutchinson, 600.

Dawson Springs quadrangle: Crider, 283.

Earlington quadrangle: Crider, 284.
Geologic maps-Continued.

Kentucky, Madisonville quadrangle: Hutchin son, 600 .

Newburg quadrangle: Hutchinson, 600 .

Pound quadrangle: Butts, 180 .

Maine, Eastport quadrangle: Bastin and Williams, 60 .

Somerset County: Clarke, 244 .

Manitoba, Lake Winnipeg region: Moore, 860.

Massachusetts: Loughlin and Hechinger, 767.

Diamond Hill-Cumberland district: Warren and Powers, 1256.

Narragansett basin: Ashley, 23.

Michigan: Smith, 1108 .

Gwinn iron district: Allen, 14.

Wayne County: Sherzer, 1081.

Minnesota, surface formations: Leverett, 741 .

Missouri, northeastern: Greene, 494.

Rolla quadrangle: Lee, 727 .

Montana, Big Sandy field: Bowen, 105.

Cleveland field: Bowen, 104.

Dillon quadrangle (parts): Winchell, 1319.

Elliston field: Stone and Bonine, 1149.

Glacier National Park, Pleistocene: Alden, 2.

Musselshell-Judith area: Bowen, 103.

Saltese: Calkins and Jones, 192.

Sheridan County: Bauer, 64.

Nevada, Rochester district: Shrader, 1048.

Yellow Pine district: Hill, 538.

New Brunswick, Carboniferous: Keele, 644.

Dalhousie: Clarke, 244 .

New Jersey: Lew is and Kümmel, 747.

Raritan quadrangle: Bayley et al., 66 .

New York: Miller, 849.

$\Lambda$ ttica-Depew quadrangles: Luther, 775 .

Long Island: Fuller, 441

North Creek quadrangle: Miller, 850.

Saratoga Springs quadrangle: Cushing and Ruedemann, 296.

Schuylerville quadrangle: Cushing and Ruedemann, 296.

Syracuse quadrangle: Fopkins, 571.

North Carolina, Dan River field: Stone, 1146.

North Dakota, Cannonball River lignite field: Lloyd, 758.

south central: Leonard, 737 .

Standing Rock Indian Reservation: Calvert et al., 193.

Northwest Territories, Coppermine River: Sandberg, 1027.

Oklahoma: Munn, 869

Cushing oil field: Okla. G. S., 886.

Fort Smith-Poteau field: Smith, 1097.

Grandfield district: Munn, 869 .

Ontario: Miller and Knight, 848.

Calabogie district: Lindeman, 749.

Kirkland Lake and Swastika gold areas: Burrows and Hopkins, 164 .

Lake Huron region: Coleman, 264.

Moose Mountain district: Lindeman, 750 .

Sudbury area: Collins, 269.

Sudbury district: Thomas, 1166.

Oregon, John Day region: Collier, 266.

Klamath Mountains: Diller, 352.

Sumpter quadrangle: Pardee and Hewett, 918.

$97921^{\circ}-$ Bull. $617-15-8$ 


\section{BIBLIOGRAPHY OF NORTH AMERICAN GEOLOGY, 1914.}

Geologic maps-Continued.

Pennsylvania, Broadtop coal field: Gardner, $452,453$.

Coatesville quadrangle: Bliss and Jonas, 101.

Susquehanna River, buried channel: Darton, 309 .

Quebec, Bell River region: Wilson, 1314.

Broadback River region: Cooke, 275.

Kewagama Lake area: Wilson, 1313.

St. Hilaire and Rougemont mountains: O'Neill, 892.

Rhode Island: J,oughlin and Hechinger, 767.

Diamond Hill-Cumberland district: Warren and Powers, 1256.

Narragansett basin: Ashley, 23.

South Dakota, Cheyenne River Indian Reservation: Calvert et al., 193.

Standing Rock Indian Reservation: Calvert et al., 193.

Tennessee, Perry County: Wade, 1239 .

Texas, northern: Munn, 869 .

Van Horn quadrangle: Richardson, 999.

Triassic: Hawkins, 520.

New Jersey and Pennsylvania: Hawkins, 520.

United States, limestone areas: Burchard and Emley, 156.

oil and gas fields, 1913: Day et al., 330.

slate deposits: Dale et al., 302.

Utah, Green River field: Lupton, 773.

San Francisco district: Butler, 172.

Vermont, Bennington: Gordon, 476.

Greensboro: Richardson and Turner, 996.

Hardwick: Richardson et al., 997.

western: Dale, 300 .

Woodbury: Richardson ct al., 997.

Virginia, Abingdon quadrangle: Stose, 1152.

Pound quadrangle: Butts, 179, 180.

Washington, Pierce County: Daniels, 308.

Republic district: Lindgren and Bancrolt, 753.

West Virginia, economic: W. Va. G. S., 1276.

Kanawha County: Krebs and Teets, 697.

Preston County: Hennen and Reger, 527.

Wyoming, $\Lambda$ tlantic City district: Trumbull, 1185.

Big Muddy dome: Barnett, 39 .

Douglas field: Barnett, 41.

Lincoln County: Schultz, 1058.

Moorcroft field: Barnett, 40.

Yukon, international boundary: Cairnes, 186.

\section{Geologic time.}

General: Miller, 844

Postglacial and interglacial: Coleman, 263.

Geological surveys. See Surveys.

Geomorphogeny. See Physiographic.

Geomorphology. See Physiographic.

\section{Georgia.}

Economic.

Asbestos: Hopkins, 568, 569.

Iron, northwest Georgia: Burchard, 150.

Slates, green: Maynard, 825.

Soapstone: Hopkins, 568.

Talc: Hopkins, 568.
Georgia-Continued.

Stratigraphic.

General: Hopkins, 568.

Paleontology.

Cretaceous, Upper, floras: Berry, 80.

Eocene flora: Berry, 80 .

Petrology.

General: Hopkins, 568.

Georgetown quadrangle, Ky.: Miller, 843.

Geophysics.

Daubree experiment and capillarity: Johnston and Adams, 623.

Earth's crust, strength: Barrell, 43-45.

Gravity anomalies: Barrell, 47.

Magmatic gases: Meunier, 840.

Mineral and rock densities at high temperatures, determination of: Day et al., 326 .

Rigidity of the earth: Michelson, 841.

Glacial geology. See also Quaternary.

General: Leverett, 745; Wright, 1346.

Cause of glacial periods: Huntington, 599; Reagan, 985.

Interglacial beds, earliest: Coleman, 265 .

- Alaska, Yakutat Bay, Prince William Sound, and Copper River region: Tarr and Martin, 1157.

- British Columbia, Tulameen district: Camsell, 197.

Vancouver Island: Clapp, 223.

southern: Clapp, 227.

California, Coast Ranges: Holway, 566 .

Yosemite, moraines: Matthes, 815 .

Canada: Wolff, 1325.

Connecticut Valley: Fairchild, 400.

Hudson-Champlain valley: Fairchild, 400.

Iowa: Hay, 522 .

Cherokee County, Nebraskan drift: Carman, 204.

Des Moines-Allerton section: Tilton, 1171.

Johnson County, post-Kansan glaciation: Leighton, 730.

Polk County: Tilton, 1172.

Maine, Eastport quadrangle: Bastin and Williams, 60.

Michigan, Wayne County: Sherzer, 1081.

Minnesota: Leverett, 740.

Montana, Clark Fork region: Davis, 324

Glacier National Park: Alden, 2, 3.

Nebraska, Kansan drift: Barbour, 36.

New Hampshịre, Jackson, moraine: Fushay, 434.

New Jersey, Raritan quadrangle: Bayley et al., 66.

New York, east central: Rich, 991 .

Erie County: Houghton, 577.

Long Island: Fuller, 441.

North Creek quadrangle: Miller, 850.

Saratoga Springs region: Cushing and Ruedemann, 296

North Dakota, Devils-Stump Lake region: Simpson, 1090.

Nova Scotia: Goldthwait, 471.

Ontario, Rainy River district: Johnston, 627.

Toronto region: Coleman, 263.

Toronto, Don River deposits: Wright, 1344. 
Glacial geology-Continued.

Pennsylvania, glacial dam in Allegheny River: Wright, 1345.

Susquehanna County: Wilson, 1312.

Warren region: Wright, 1345 .

Wyoming Valley: Darton, 309.

Quebec, Magdalen Islands: Goldthwait, 474.

South Dakota, Sioux Falls region: Carman, 205.

Vermont, Hardwick: Richardson et al., 997.

Woodbury: Richardson et al., 997.

Glacial epoch: Reagan, 985.

Glacial lakes. See also Beaches; Shoro lines; Terraces.

General: Wright, 1346:

Algonquin beach: Leverett, 743 .

Lake Agassiz, Ontario: Johnston, 627.

Michigan, Wayne County: Sherzer, 1081.

Montana, Lake Missoula: Stone, 11.48.

New York, Erie County: Houghton, 577.

North Creek quadrangle: Miller, 850.

North Dakota, Minnewauken and Wamduska: Simpson, 1090.

Ohio, Craighton Lake: Hubbard, 586, 587; Leverett, 742 .

Ontario, Toronto region: Wright, 1344.

Glacier National Park: Alden, 2, 3; Campbell, 196.

Glacial period. See Glacial geology.

Glaciers.

General.

Variation, 1913: Reid, 989.

- Alaska: Brooks, 125.

Yakutat Bay, Prince William Sound and Copper River region: 'Tarr and Martin, 1157. British Columbia: Ogilvie, 885.

Montana, Glacier National Park: Alden, 2, 3.

Washington, Mount Rainier: Matthes, 812, 813.

Glass sand.

Indiana: Barrett, 54.

Glauconite, genesis: Palmer, 914.

Globe district, $\Lambda$ rizona: Tovote, 1178 .

Gold.

General.

Classification of deposits: Lindsley, 755.

Deposition in nature: Lenher, 735.

Alaska: Brooks, 124.

Chisana district: 33 rooks, 123.

Chisana field: Cairnes, 188.

Fairbanks district: Chapin, 218.

Hanagita-Bremner region: Moffit, 854.

Iditarod-Ruby region: Eakin,'373.

Ketchikan region: Smith, 1106.

Matanuska and Nelchina valleys: Martin and

Mertie, 808 .

Port Wells district: Johnson, 618.

Prince William Sound: Johnson, 617.

Ruby district: Eakin, 374.

Seward Peninsula: Chapin, 220, 221.

Valdez Creek district: Moffit, 856 .

Willow Creek district: Capps, 202.

Yakataga district: Maddren, 798.

Yukon-Koyukuk region: Eakin, 375.

Yukon-Tanana region: Chapin, 219.
Gold-Continued.

British Columbia, Graham Island: MacKenzie, 793.

Hazelton: Malloch, 803.

Lillooet area: Bateman, 62 .

Prince Royal Island: McConnell, 782.

Quadra Island: Cairnes, 191.

Tulameen district: Camsell, 197.

California, Alleghany district: Ferguson, 417.

auriferous gravel channels: Alling, 16 .

Inyo and White Mountains: Knopf, 686 .

Weaverville quadrangle: Diller, 348; Ferguson, $\mathbf{4 1 6 .}$

Eastern States: MeCaskey, 776.

Idaho, Dixie district: Livingston and Stew art, 757 .

Saw tooth quadrangle: Umpleby, 1210.

Manitoba, Rice Lake district: Harding, 512; Wallace, 1251.

Montana, Dillon quadrangle: Winchell, 1319.

Marysville district: Goodale, 475 .

Nevada, Rochester district: Schrader, 1048.

Yellow Pine district: Hill, 538.

New Mexico, Pinos Altos district: Wade, 1241.

Nova Scotia, Cape Breton Island, Clyburn Valley: Wright, 1350.

Greenfleld and Liverpool areas: Faribault, 402.

Lunenburg County: Faribault, 406.

Oldham district: Faribault, 403 .

Queens County: Faribault, 405.

Ontario, Kirkland Lake district: Hardinge, 513 .

Kirkland Lakeand Swastika gold areas: Burrows and Hopkins, 164.

Michipicoten district: Means, 827.

Porcupine district: Dobbs, 356.

Swastika area: Bruce, 142.

Oregon, Baker district: Grant and Cady, 487. northeastern: Swartley, 1155.

southwestern: Diller, 352.

Sumpter quadrangle: Pardee and Hewett, 918.

Quebec, Kewagama Lake area: Wilson, 1313.

Saskatchewan, Beaver Lake district: Bruce, 144.

Washington, northeastern: Bancroft, 31 .

Republic district: Lindgren and Bancroft, 753.

Wyoming, Atlantic City district: Trumbull, 1187.

Lincoln County: Schultz, 1058.

Wind and Bighorn rivers: Schrader, 1047.

Yukon, Klond ike district: Bell, 75.

Klondike region: MacLean, 797.

Gorgosaurus: Lambe, 708.

Graham Island, British Columbia: MacKenżle, 793.

Grand Canyon, Ariz.: Noble, 880.

Granite.

General.

Hydrothermal alteration: Moore, 864.

Origin in sills: Schofield, 1039.

Colorado, Gunnison: Hunter, 595.

Missouri: Tarr and Neuman, 1160.

New York: Newland, 874.

Quebec, eastern: Mailhiot, 800.

Vermont, Hardwick: Richardson ct al., 997.

Woodbury: Richardson et al., 997. 
Granitization, regional: Sederholm, 1064.

Graphic methods for solution of geologic problems: 'Smith, 1111.

\section{Graphite.}

Origin: Stansfield, 1119.

New Jersey, Raritan quadrangle: Bayley et al., 66.

Quebec, Buckingham area: Wilson, 1315.

United States: Bastin, 59.

\section{Graptolites.}

Quebec, Levis: Raymond, 981, 982.

\section{Gravel.}

United States: Stone, 1147.

Gravity anomalies, interpretation: Gilbert, 459.

Great Basin, physiography: Free, 439.

Great Basin lakes: Gale, 442 .

Great Basin region, potash and salines: Young, 1352.

\section{Greenland.}

Mineralogy.

Ussingite :Böggild, 102.

Groundhog anthracite field, British Columbia: Evans, 397.

\section{Gypsum.}

General.

Origin: Cole, 259; Wallace, 1252.

California, Bully Hill district: Boyle, 113.

Iowa: Kay, 638 .

Centerville: Kay, 638 .

Manitoba: Kindle, 676; MacLean and Wallace 796.

New York: Newland, 874.

Southern States: Wilder, 1297.

Gwinn district, Michigan: Allen, 14.

Harney Peak region, South Dakota: Ziegler, 1355.

\section{Hawailan Islands.}

Dynamic and structural.

Earthquakes, 1868: Wood, 1328.

Kilauea: Day, 325; Hawaiian Volcano Observatory, 518,519 .

Lava tunnels: Hobbs, 547.

Volicanoes, general: Jaggar, 612.

Petrology.

Molybdenum, occurrence: Ferguson, 418.

Hawthorn formation, correlation: Vaughan and Cooke, 1235.

History, philosophy, etc.

Correlation, early: Keyes, 667.

Geological Society of America: Fairchild, 401; Winchell, 1322.

organization: Stevenson, 1128.

Geological societies in United States: Winchell, 1321.

Gulf Coastal Plain geology: Smith, 1099.

Homocrinus: Kirk, 683.

Hot Springs. See Thermal waters.

Horse, evolution: Matthew, 818.

Hudson River, geology: Kunz, 700.

Huronian. See Pre-Cambrian.

Hypacrosaurus: Gilmore, 462.

Ice age. See Glacial geology.
Ice ages, ancient.

Massachusetts, Boston Basin, Paleozoic: Lahee, 702 .

Squantum tillito: Sayles, 1034.

Idaho.

Economic.

Dixie district: Livingston and Stewart, 757.

Lead-silver, Dome district: Umpleby, 1209.

Mackay copper deposits, Idaho: Umpleby, 1208, 1209, 1212.

Mining industry, 1913: Bell, 76.

Mullan: Calkins and Jones, 192.

Phosphate deposits northeast of Georgetown: Richards and Mansfield, 995.

Sawtooth quadrangle: Umpleby, 1210.

Teton Basin coal field, Horseshoe Creek district: Woodruff, 1331.

Stratigraphic.

Cambrian: Burling, 157.

Georgetown region: Richards and Mansfield, 995.

Sawtooth quadrangle: Umpleby, 1210.

Teton Basin coal field, Horseshoe Creek district: Woodruff, 1331.

Petrology.

Cœur d'Alene monzonite: Stewart, 1142.

Mineralogy.

Chrysocolla, Mackay: Umpleby, 1211.

Custerite, Custer Co.: Umpleby et al., 1214.

Iditarod-Ruby region, Alaska: Eakin, 373.

Igneous and volcanic rocks. See also Intrusions; Magmas.

General: Daly, 304; Iddings, 606.

Average igneous rock: Mead, 826 .

Classification: Tyrrell, 1193.

Eruptive, use of term: Lahee, 701.

Origin: Daly, 304:

Pillow lava, origin: Lewis, 746 .

Serpentine: Julien, 635.

Silicates, constitution: Clarke, 238.

Alaska, Hanagita-Bremner region: Moffit, 854 . international boundary: Cairnes, 186.

Port Wells district: Johnson, 618 .

Yukon-Koyukuk region: Eakin, 375.

Alberta, Crowsnest volcanics: MacKenzie, 794.

Arizona, Buckskin Mountains: Blanchard, 96.

Bermuda Island: Pirsson, 953, 954.

British Columbia, East Kootenay: Schofield, $1039,1040,1042$.

Boundary district: LeRoy, 738.

Field area: Allan, 5 .

Fraser River valley: Bowen, 106.

Graham Island: MacKenzie, 793.

Moyie sills: Bailey, 28.

Nanaimo area: Clapp, 225.

Purcell Range: Schofield, 1042.

Savona area: Rose, 1016.

Texada Island: McConnell, 779.

Thompson River valley: Drysdale, 369.

Vancouver Island: Clapp, 223.

Duncan area: Clapp and Cooke, 230.

Kyuquot Sound: Clapp, 229.

California, Alleghany district: Ferguson, 417.

Bully Hill district: Boyle, 113.

Inyo and White Moụntains: Knopf, 686, 
Igneous and volcanic rocks-Continued.

California, San Francisco district: Lawson, 724.

Weaverville quadrangle: Ferguson, $\mathbf{4 1 6 .}$

Colorado, A pishapa quadrangle: Cross, 288.

Georgia, northern: Hopkins, 568.

Idaho, Alder Creek district: Umpleby, 1209.

Cour d'Alene: Stewart, 1142.

Mullan: Calkins and Jones, 192.

Sawtooth quadrangle: Umpleby, 1210.

Maine, Eastport quadrangle: Bastin and Williams, 60 .

Ogunquit: Keeley, 647.

Massachusetts, Diamond Hill-Cumberland dis: trict: Warren and Powers, 1256.

Essex County: Clapp, 222.

Pigeon Cove: Keeley, 647 .

Montana, Dillon quadrangle: Winchell, 1319.

Elliston field: Stone and Bonine, 1149 .

Saltese: Calkins and Jones, 192.

Nevada, Rochester district: Schrader, 1048.

Yellow Pine district: Hill, 538.

New Brunswick, St. John area: Hayes, 523.

New Jersey, Raritan quadrangle: Bayley et al., 66.

New Mexico, Sierra Blanca field: Wegemann, 1268.

New York, Adirondack region: Miller, 851 .

Saratoga Springs region: Cushing and Ruedemann, 296.

southeastern: Fettke, 420 .

Nova Scotia, Arisaig-Antigonish district: Williams, 1300.

Ontario, Kirkland Lake and Swastika gold areas: Burrows and Hopkins, 164.

Lake Huron region: Coleman, 264.

Rainy Lake: Lawson, 721.

Sudbury district: Brackenbury, 114.

Oregon, southwestern: Diller, 352; Winchell, 1320.

Sumpter quadrangle: Pardee and Hewett, 918.

Pennsylvania, Coatesville quadrangle: Bliss and Jones, 101.

Quebec, Bell River region: Wilson, 1314.

Buckingham area: Wilson, 1315.

Kewagama Lake area: Wilson, 1313.

St: Hilaire and Rougemont mountains: O'Neill, 892.

southern: Dresser, 367.

Rhode Island, Diamond Hill-Cumberland district: Warren and Powers, 1256.

Texas, Van Horn quadrangle: Richardson, 999.

Utah, Canyon Range: Loughlin, 764.

San Francisco district: Butler, 172.

Vermont, Greensboro: Richardson and Turner, 996.

Hardwick: Richardson et al., 997.

Woodbury: Richardson et al., 997.

Washington, northeastern: Bancroft, 31.

Yukon, international boundary: Cairnes, 186.

White River district: Cairnes, 190.

Igneous intrusion. See Intrusions.
Illinois.

General.

Chicago, bed-rock topography: Peattie, 926.

Economic.

Bond, Macoupin, and Montgomery counties Blatchley, 100.

Greenville gas field: Blatchley, 100.

Lead and zinc, northwestern Illinois: Cox, 278.

Oil, Plymouth field: Blatchley, 99.

Oil and gas, Colchester and Macomb quadrangles: Hinds, 543 .

Oil fields: Wheeler, 1277.

Crawford and Lawrence counties: Blatchley, 98.

Dynamic and structural.

Accumulation of coal beds: Savage, 1032.

Earthquake, January 2, 1912: Udden, 1199.

Tufa, Danville: Decker, 332.

Stratigraphic.

General: Blatchley, 100.

Alexandrian series: Savage, 1031.

Bond, Macoupin, and Montgomery counties: Blatchley, 100.

Borings: Udden, 1200.

La Salle: Cady, 185.

Chester group: Weller, 1269.

Colchester and Macomb quadrangles: Hinds, 543.

Crawford County: Blatchley, 98.

Devonian, Rock Island region: Ekblaw, 385.

Lawrence County: Blatchley, 98.

Northwestern Illinois: Cox, 278.

Section, Rock Island-Joliet: Cady, 185.

Sangamon County limestones: Crook, 285.

Pabeontology.

Mississippian Brachiopoda: Weller, 1270.

Indiana.

General.

Survey, 38th report: Barrett, 52 .

Economic.

Glass sands: Barrett, 54.

Sullivan County oil field: Barrett, 53.

Stratigraphic.

Cincinnatian series, Tanners Creek section: Cumings and Galloway, 295.

Richmond, upper: Shideler, 1082.

Paleontology.

- Cincinnatian series, Tanners Creek section: Cumings and Galloway, 295.

Cordaitean wood, black shale: Elkins and Wieland, 386.

Gastropoda, Spergen: Roundy, 1018.

Insecta.

Colorado, Florissant: Cockerell, 256.

Bombyliidæ: Cockerell, 250.

Coleoptera: Wickham, 1292.

Diptera: Cockerell, 254.

Orthoptera: Cockerell, 252.

sawfly: Cockerell, 253.

Interference ripples: Kindle, 674 .

Intraformational corrugation: Clarke, 245. 
Intrusions. See also Dikes; Igneous and volcanic rocks; Laccoliths; Magmas.

General: Iddings, 603.

Boulder batholith: Knopf, 688.

British Columbia, Field area: Allan, 5.

Montana, Butte: Lawson, 722.

New Jersey, Highlands: Fenner, 413.

South Dakota, Black Hills, granite intrusion: Paige, 906 .

Invertebrata (general). See also Anthozoa, Brachiopoda, Bryozoa, Crustacea, Echinodermata, Foraminifera, Insecta, Mollusca, Problematica, Spongida, and Vermes.

Anticosti Island faunas: T'wenhofel, 1190.

Arctic regions, Ellesmere Land: Holtedahl, 562.

British Columbia, Queen Charlotte Island: Burwash, 166 .

California, Fernando group: English, 393.

San Juan district: Anderson and Martin, 18.

Temblor Basin: Anderson and Martin, 18.

Canada: Kindle, 678, 679.

Carboniferous, West Virginia, Preston Co.: Price, 963.

Devonian, Oriskany, Parlin, Maine: Pirsson and Schuchert, 955.

Lorraine faunas, New York and Quebec: Foerste, 428

Maine, Devonian: Clarke, 244.

Martinez fauna, Eocene: Dickerson, 340.

Michigan, Dundee limestone fauna: Grabat, 482.

New Brunswick, Devonian: Clarke, 244.

New York, Devonian: Clarke, 244.

Rectogloma: Van Tuyl and Berckhemer; 1227.

Rogers Gap fauna, Kentucky: Foerste, 427.

Tertiary, California: Anderson and Martin, 18.

Triassic, marine: Smith, 1102

West Virginia, Kanawha County: Price, 962.

Ione formation, California: Dickerson, 346.

Iowa.

General.

Northeastern Iowa: Trowbridge, 1180.

Report State geologist: Kay, 640, 641 .

Economic.

Coal analyses: Hixson, 544.

Gypsum, Centerville, Appanoose County: Kav 638.

Mineral production, 1911 and 1912: Kay, 642.

Road and concrete materials: Beyer and Wright, 90.

Physiographic.

General: Lees, 729.

Drainage changes: Lees, 729 .

Earth movements: Lees, 729 .

Stratigraphic.

General: Keyes, 660.

Alexandrian series: Savage, 1031.

Bethany limestone: Tilton, 1170.

Boring, Bedford: Kay, 640.

Carboniferous: Tilton, 1170 .

Carboniferous terranes, correlation: Keyes, 661 .

Chart of formations: Keyes, 666 .

Cretaceous terranes: Keyes, 655.

Devonian: Keyes, 657.

Drift, Cedar Rapids region: Shipton, 1085. southwestern Iowa: Gow, 481
Iowa-Continued.

Stratigraphic-Continued.

Graf section: Thomas, 1165.

Ice ages: Keyes, 664 .

Nebraskan drift, Little Sioux Valley, Cherokee County: Carman, 204

Pleistocene: Hay, 522.

Pleistocene section, Des Moines to Allerton: Tilton, 1171.

Post-Kansan glaciation, Johnson County: Leighton, 730 .

Pre-Cambrian: Keyes, 662,668 .

Sioux quartzite: Keyes, 668

Tertiary beds: Keyes, 656 .

W isconsin drift, Polk Co.: Tilton, 1172.

Paleontology.

Cactocrinus: Wood, 1326.

Pleistocene Mammalia: Hay, 522.

Psaronius: Farr, 407

Petrology.

Dolomite: Knight, 684.

Iron.

General: Eckel, 383.

Genesis of Paleozoic interbedded deposits: Earle, 380.

Titaniferous ores, origin: St. Clair, 1020.

Alabama, northeast: Burchard, 150.

Russellville district: Sawyer, 1033.

Arizona, Buckskin Mountains: Blanchard, 96.

British Columbia, Texada Island: McConnell, 779 .

California: Diller, 353.

Colorado, Leadville: Argall, 20.

Cuba: Woodbridge, 1329.

Georgia, northwest: Burchard, 150.

Kentucky, Edmonson and Grayson countins: Bryant, 147.

Lake Superior: Leith, 733.

Michigan: Allen, 11.

Mississippi: Lowe, 768 .

Montana, Blackfeet Reservation: Steb nger, 1124

Newfoundland, Wabana ore: Hayes, 524

New Jersey, Raritan quadrangle: Bayley et al., 66.

New York: Newland, 874.

Nova Scotia, Arisaig-Antigonish district: Williams, 1300.

Cape Breton: Lindeman, 751.

Ontario, Calabogie distict: Lindeman, 749.

Moose Mountain: Collins, 268; Lindeman, 750. southeastern: Miller and Knight, 848.

Quebec: Dulieux, 371.

Tennessee, eastern: Burchard, 150 .

Waynesboro quadrangle: Drake, 366 .

United States: Burchard, 155.

Wisconsin, "Clinton" ore: Thwaites, 1169.

Isostasy.

General: Barrell, 46-49; Bowie, 110; Holland, 558; Spencer, 1117.

Asthenosphere: Barrell, 47.

Earth's crust, strength: Barrell, 43-45.

Geodetic evidence: Bowie, 111.

Gravity anomalies: Barrell, 47; Gilbert, 459.

Isotelus gigas, ontogeny: Raymond, 979 .

Jointing.

Laws of jointing: Stevens, 1136. 
Jurassic.

Stratigraphy.

Alaska, Hanagita-Bremner region: Moffit, 854 .

Alberta, Sheep River field: Dowling, 362, 364.

South Fork district: MacKenzie, 792.

British Columbia, Graham Island: Clapp, 226; MacKenzie, 793.

Nanaimo area: Clapp, 225.

Prince Rupert-Aldermere: McConnell, 781.

Quadra Island: Cairnes; 191.

Texada Island: McConnell, 779.

Thompson River valley: Drysdale, 369 .

Tulameen district: Camsell, 197.

British Columbia, Vancouver Island: Clapp, 223.

Duncan area: Clapp and Cooke, 230.

Kyuquot Sound: Clapp, 229. southern: Clapp, 227.

California, Coalinga region: Pack and English, 903.

San Francisco district: Lawson, 724.

Colorado, southwestern: Cross and Larsen, 290.

Idaho, southeastern: Richards and Mansfield, 995.

Montana, Cleveland field: Bowen, 104.

Oregon, southwestern: Diller, 352.

southwestern: Winchell, 1320.

Utah, Green River field: Lupton, 773.

Wyoming, Big Muddy dome: Barnett, 39.

Douglas field: Barnett, 41.

Lincoln County: Schultz, 1058.

Shoshone River section: Hewett, 534.

Paleontology.

Alaska, Cape Lisburne, Jurassic flora: Knowlton, 690 .

Kanawha series: Fennen, 526 .

Kansas.

General.

Geologic history: Wooster, 1338.

Stratigraphic.

Moraine, Topeka: Wooster, 1337.

Palcontology.

Cretaceous vertebrates: Sternberg; 1131.

Fish locality: Twenhofel and Dunbar, 1191.

Pennsylvania vertebrates: T.wenhofel, 1189.

Platygonus; Peterson, 937.

Underground water.

Ground-water table, lowering of: Cook, 274.

Well waters: Haworth, 520 .

\section{Kaolin}

General: McDonald, 790.

\section{Kentucky.}

General.

Dix River: Foerste, 423.

Ordovician rocks, composition: Foerste, 425.

Report of Geological Survey: Hoeing, 554.

Economic.

Asphalt rock: Crump, 294.

Barytes: Fohs, 430 .

Clay: Crider, 282; Easton, 382.

Coal, analyses: Hoeing, 556 .

Big Sandy Valley: Hoeing, 555.

Bull Creek region: Hodge, 552 .

Carr Fork field: Hodge, 552

Kentucky River, Perry and Knott counties: Hodge, 551 .

Licking River, Magoffin County: Hodge, 550.
Kentucky-Continued.

Economic-Continued.

Coal, North Fork of Kentucky River: Hoeing, 555 .

Pound quadrangle: Butts, 180. western field: Hutchinson, 600 .

Dawson Springs quadrangle: Crider, 283.

Earlington quadrangle: Crider, 284.

Edmonson County: Bryant, 147.

Fire clays: Crider, 282

Grayson County: Bryant, 147.

Oolitic limestones, Warren County: Crump, 293.

Owensboro quadrangle: Crider, 281.

Phosphate, central Kentucky: Toerste, 426.

Soils: Jones, 632.

Tell City quadrangle: Crider, 281 .

Waverly formation: Morse and Foerste, 867.

Wayne County: Munn, 869 .

Stratigraphic.

Central Kentucky: Foerste, 426.

Dawson Springs quadrangle: Crider, 283.

Earlington quadrangle: Crider, 284.

Edmonson County: Bryant, 147.

Georgetown quadrangle: Miller, 843.

Grayson County: Bryant, 147.

North central Kentucky: Foerste, 427.

Ordovician, central Kentucky: Foerste, 425.

Pound quadrangle: Butts, 180.

Waverly formation: Morse and Foerste, 867.

Wayne County: Munn, 869 .

Western coal field: Hutchinson, 600 .

\section{Paleontology.}

Cystoidea: Foerste, 429.

Georgetown quadrangle: Miller, 843.

Ordovician faunas: Foerste, 424.

Plants, Waverly, Boyle County: Scott and Jefirey, 1061.

Rogers Gap fauns: Foerste, 427.

Kewagama Lake area, Quebec: Wilson, 1313.

Kirkland Lake district, Ontario: Hardinge, 513; Spearman, 1116.

Klondike region: MacLean, 797.

Laccoliths.

Montana, Butte: Lawson, 722.

Lakes. Sec also Glacial lakes.

Florida: Sellards, 1068, 1073

Great Basin region: Gale, 442 .

North Dakota, Devils-Stump Lake reginn: Simpson, 1090.

Ponnsylvania, Susquehanna County: Wilson, 1312 .

Wisconsin: Birge and Juday, 91.

Lakes, glacial. See Glacial lakes.

Lamellibranchiata. See Pelecypoda.

Lance formation, age: Brown, 133; Knowlton, 692; Stanton, 1122

\section{Landslides.}

General: Hovey, 579.

Lassen Peak, eruptions: Diller, 351.

Lava.

General: Buttram, 177; Iddings, 603; Lewis, 746.

Pillow lava, origin: Lewis, 746.

Alaska, Prince William Sound: Capps, 203.

Hawaii: Ferguson, 418 
Lava tunnels: Hobbs, 547.

Lead.

British Columbia, Field area: Allan, 5.

California, Darwin district: Knopf, 687.

Inyo and White Mountains: Knopf, 686.

Central States: Butler and Dunlop, 175.

Eastern States: McCaskey, 776.

Idaho, Dome district: Umpleby, 1209.

Mullan: Calkins and Jones, 192

Saw tooth quadrangle: Umpleby, 1210.

Illinois, northwestern: Cox, 278.

Mexico, Zimapan (Hidalgo): Lindgren and Whitehead, 754.

Missouri, southeastern: Cantwell, 201; Nason, 872.

Montana, Dillon quadrangle: Winchell, 1319.

Park County: Gardner, 451.

Saltese: Calkins and Jones, 192.

New Mexico, Organ Mountain district: Welsh, 1274.

Oklahoma, Arbuckle Mountains: Becker, 71.

United States: Siebenthal, 1087.

Utah, Canyon Range: Loughlin, 764.

San Francisco district: Butler, 172.

Washington, northeastern: Bancroft, 31 .

Leptoceratops, Alberta: Brown, 137.

Lignite. See also Coal.

Montana, Sheridan County: Bauer, 64.

North Dakota, Cannonball River lignite field: Lloyd, 758.

south central: Leonard, 737,

Standing Rock Indian Reservation: Calvert et al., 193.

Oregon, John Day region: Collier, 266 .

South Dakota, Cheyenne River Indian Reservation: Calvert et al., 193.

Standing Rock Indian Reservation: Calvert et al., 193.

Texas: Phillips and Worrell, 950.

Lime.

United States: Burchard and Emley, 156; Stone, 1147 .

\section{Limestone.}

General:

$\Lambda$ lgal agency in formation: Walcott, 1246.

Origin: Dale, 300

Kentucky, Warren County: Crump, 293.

Maryland: Grasty, 489 .

New York: Newland, 874.

Oregon: Williams, 1299.

United States: Burchard and Emley, 156.

Lithla minerals.

South Dakota, Harney Peak region: Ziegler, 1355 .

Little Lake district, Michigan: Allen and Barrett, 15.

Livermore Valley, California: Branner, 116; Lawson, 720 .

Lockatong formation, Triassic: Hawkins, $\mathbf{5 2 0}$.

Loess.

General: Hay, 522; Shaw, 1077.

Characteristics: Gow, 481 .

Origin: Shaw, 1077.

\section{Louisiana.}

General.

Mud lumps of Mississippi River: Shaw, 1075 .

Physiographic.

Mississippi delta: Shaw, 1078.

Lower Silurian. . See Ordovician.

Lysorophus, Permian, Texas: Huene, 588.

Mackay copper deposits, Idaho: Umpleby, 1208, 1209.

Magmas. See also Intrusions.

General: Daly, 304; Iddings, 603.

Adirondack region: Miller, 851 .

Differentiation: Harker, 514; Iddings, 604.

Fractional crystallization: Harker, 514 .

Granitization, regional: Sederholm, 1064 .

Harney Peak region, South Dakota: Ziegler, 1354.

Magmatic gases: Meunier, $\$ 40$

New Jersey, Highlands: Fenner, 412, 413.

New York, Adirondacks: Miller, 851.

Sonth Dakota, Black Hills, granite intrusion: Paige, 906 .

\section{Magnesite.}

General: Morganroth, 865 .

California: Gale, 448.

Nevada: Gale, 448.

United States: Yale and Gale, 1351.

\section{Magnetite.}

Montana, Blackfeet Reservation: Stebinger, 1124 .

Maine.

General.

Mount Desert Island: Morse, 866 .

Economic.

Eastport quadrangle: Bastin and Williams, 60. Physiographic.

Eastport quadrangle: Bastin and Williams, 60. Statigraphic.

Devonian, Chapman Plantation: Clarke, 244.

Somerset County: Clarke, 244.

Eastport quadrangle: Bastin and Williams, 60.

Oriskany formation, Parlin Stream: Pirsson and Schuchert, 955 .

Paleontology.

Devonian, Somerset County: Clarke, 244.

Oriskany fauna, Parlin Stream: Pirsson and Schuchert, 955.

Petrology.

Igneous rocks, Ogunquit: Keeley, 647.

Mammalia.

Artiodactyla, bunodont: Sinclair, 1091.

Brontotherium, restoration: Oshorn, 897.

California, Rancho La Brea, mylodont sloths: Stock, 1143.

Castoroides, Madison County, N. Y.: Smith, 1094.

Chalicotheroidea, osteology: Holland and Peterson.

Connecticut, Farmington, mastodon: Lull, 772.

Cuba: Matthew, 822 .

Cumberland Pleistocene fauna: Gidley, 457.

Delphinoid cetacean, Maryland: True, 1184.

Diploceras, Uinta Eocene: Peterson, 935. 
Mammalia-Continued.

Dolichorhinus, Uinta beds: Peterson, 939.

Dolphin, California: Lull, 771.

Elephant, evolution: Lull, 770 .

restorations: Osborn, 898 .

Eocene faunas: Matthew, 821 .

Eotitânops, restoration: Osborn, 897.

Eotitanotherium: Peterson, 938.

Heterotitanops, Uinta beds: Peterson, 936.

Horse, evolution: Matthew, 818 .

Iowa, Pleistocene: Hay, 522 .

Mastodon, restorations: Osborn, 808.

Multituberculata: Broom, 127.

Mylodontidæ, Rancho La Brea, Cal.: Stock, 1143.

Nebraska, Brown County: Barbour, 35 .

Nevada, northeastern: Merriam, 833.

Truckee beds, proboscidean tooth: Buwalda, 182.

New York, Onondaga Lake: Smith, 1096.

Notharctus, Eocene lemuroid: Gregory, 498.

Origin: Broom, 129.

Platygonus, Kansas: Peterson, 937.

Promerycochœrus, Nebraska: Peterson, 940.

Pyrotherium fauna: Loomis, 761, 762.

Sea-otter (Latax): Taylor, 1162.

Sloth, mylodont, Rancho La Brea, Cal.: Stock, 1144 .

Tertiary correlation: Merriam, 832 .

Titanothere, Uinta Eocene: Peterson, 935.

Titanotheres, phylogeny: Osborn, 896, 900.

Mammoth Cave, bibliography: Hovey and Call, 580.

Man, fossil.

California, Rancho La Brea: Merriam, 830, 831.

\section{Manganese.}

New foundland: Dale, 299.

United States: Hewett, 535.

\section{Manitoba.}

\section{Economic.}

Gypsum: MacLean and Wallace, 796.

Gypsumville: Wallace, 1252.

Rice Lake gold district: Harding, 512; Wallace, 1251.

Saline springs: Cole, 260.

Salt: MacLean and Wallace, 796.

\section{Stratigraphic.}

Devonian: Kindle, 676 .

Lake Winnipeg region: Moore, 860 .

Pre-Cambrian: Miller and Knight, 848.

Silurian: Kindle, 676 .

Petrology.

Lake Winnipeg region: Moore, 860 .

Map making. See Cartography.

Maps. See Cartography and Geologic maps.

Marble.

Alaska, Juneau, Skagway, and Sitka districts: Burchard, 152.

California, Barstow: Pack, 901.

New York: Newland, 874.

Vermont: Perkins, 932.

eastern: Dale, 301 .

western: Dale, 300 .

Marquesas atoll: Vaughan, 1231.
Maryland.

Economic.

Copper ores, New London mine, Frederick County, Butler and McCaskey, 176.

Limestones: Crasty, 489.

Stratigraphic.

Iimestones: Grasty, 489.

Palcontology.

Cretaceous floras: Berry, 84 .

Delphinoid cetacean, Miocene: True, 1184.

\section{Massachusetts.}

\section{Stratigraphic.}

Cumberland-Diamond Fill district: Warren and Powers, 1256.

Diamond Hill-Cumberland district: Warren and Powers, 1256.

Glaciation, Paleozoic, Boston Basin: Lahee, 702.

Narragansett Basin: Loughlin and Hechinger, 767.

Squantum tillite: Sayles, 1034.

\section{Paleontology.}

Paradoxides haywardi, Braintree: Raymond, 978.

Unios, Triassic: Troxell, 1183.

Vitrinella, Boston: Clapp, 231.

Petrology.

Diamond Hill-Cumberland district: Warren and Powers, 1256.

Igneous rocks, Essex County: Clapp, 222.

Igneous rocks, Pigeon Cove: Keeley, 647.

\section{Mastodon.}

Connecticut: Schuchert, 1052.

Nebraska, Brown County: Barbour, 35 .

\section{Meandering.}

Gencral: Purdue, 971.

Medina formation: Schuchert, 1054.

Medina sandstone: Kindle, 680.

Medusæ. See also Fydrozoa.

Carboniferous jellyfish, Nebraska: Barbour, 37.

Meetings. See Associations.

Monominee iron range, extension' eastward: Allen, 13.

Mercury. See Quicksilver.

Mesozoic (undifferentiated).

Alaska, international boundary: Cairnes, 186.

Yukon-Koyukuk region: Jakin, 375.

Yukon, international boundary: Cairnes, 1 sG. White River district: Cairnes, 190.

Metallic elements, relative abundance: Clarke and Steiger, 240.

\section{Metamorphism.}

Coal: White and Thiessen, 1285.

Crystalloblastic order: Lahee, 703.

Hydrothermal alteration of granite: Moore, 864 .

Idaho, Mackay: Umplehy, 1208.

Secondary silicate zones: Higgins, 536; Uglow, 1206.

Utah, San Francisco district: Butler, 172.

Meteor Crater, Arizona: Merrill, 836. 
Meteorites.

General: Pickering, 952.

Composition, relation to earth: Farrington, 408.

Origin: Pickering, 951

Ahumada, Chihuahua,Mexico: Farrington, 409.

Arispe, Ariz.: Farrington, 409.

Bishop Canyon, Colo.: Farrington, 409.

Davis Mountains, Tex.: Farrington, 409.

Glorieta, N. Mex.: Hills, 542.

Kilbourn, Wis.: Farrington, 409.

\section{Mexico.}

General.

Bibliography: Thayer, 1164.

Economic.

Michoacan: Grothe and Salazar, 501; Salazar Salinas, 1022.

Oil fields: Ordonez, 893.

Zimapan, Hidalgo, jamesonite deposit: Lindgren and Whitehead, 754.

\section{Mineralogy.}

Meteorites, Ahumada, Chihuahua: Farrington, 409.

Mica.

British Columbia, Tete Jaune Cache and Big Bend districts: De Schmid, 335.

Canada: De Schmid, 334.

New Hampshire, Grafton: Pulsifer, 966.

New York: Newland, 874.

Ontario: De Schmid, 334.

Quebec: De Schmid, 334.

South Dakota, Harney Peak region: Ziegler, 1355.

United States: Sterrett, 1133, 1134.

\section{Michigan.}

General.

Director's report: Allen, 12.

Economic.

Copper in 1913: Hore, 573.

Iron: Allen, 11.

Menominee iron range, extension eastward: Allen, 13.

Mineral resources: Allen, 9, 10.

nonmetallic minerals: Smith, 1109.

Natural gas: Smith, 1108.

Petroleum: Smith, 110S.

Saginaw oil field: Smith, 1107.

Salt deposits: Cook, 273.

Wayne County: Sherzer, 1081.

Physiographic.

Wayne County: Sherzer, 1081.

Stratigraphic.

General: Smith, 1108.

Gwinn iron district, pre-Cambrian: Allen, 14.

Little Iake district, pre-Cambrian: Allen and Barrett, 15.

Wayne County: Sherzer, 1081.

Paleontology.

Dundee limestone fauna: Grabau, 482.

Migration of poles: Barrell, 51.

Mine waters.

Ore-bearing currents: Lane, 715 .

Mineral paints.

United States: Hill, 540.
Mineral resources -(general). See also Economic under the names of States.

Southern States: Pratt, 961 .

United States: Smith, 1101.

Mineral.waters.

New York: Newland, 874.

Saratoga Springs region: Cushing and Ruedemann, 296.

United States: Dole, 358.

Mineralizing solutions, intrusive pressure: Stevens, 1138.

Mineralogy (general). See also Meteorites; Technique. For rcgional, see names of States. For particular minerals, sce list, $p$.

Amphiboles, optical study: Ford; 432 .

Azurite and alamosite: Merwin, 838 .

Binary system $\mathrm{MgO}-\mathrm{SiO}_{2}$ : Bowen and Andersen, 109 .

Bornite, composition: Kraus and Goldsberry, 696.

Determination of minerals: Hobbs, 548 .

Determination of common minerals and rocks, tables for: Tarr, 1159.

Interpretation of mineral analyses: Wells, 1272 . Isomorphism between calcite and dolomite: Foot and Bradley, 431.

Microscope, reflecting: Ray, 976 .

Nomenclature: Rogers, 1011; Wherry, 1280.

Sulpho-minerals: Kraus and Golsberry, 696 .

Ternary system; diopside, forsterite, silica: Bowen, 107.

Tests on opaque minerals: Bruce, 143.

Textbook: Foye, 435.

Variations in composition: Wherry, 1279.

Mining subsidence: Knox, 694.

Minnesota.

Economic.

Clays and shales: Grout and Soper, 502.

Stratigraphic.

General: Grout and Soper, 502 .

Map of surface formations: Leverett, 741 .

Pleistocene: Leverett, 740.

Paleontology.

Dikelocephalinæ, Cambrian: Walcott, 1244.

Miocene. See Tertiary.

Mississippi.

Gencral.

Soils: Logan, 760.

Economic.

Iron: Lowe, 768 .

Paleontology.

Nipadites, Eocene: Berry, 81.

Mississippian. See Carboniferous.

Missouri.

Economic.

Coal, northeastern Mo.: Greene, 494.

Granites: Tarr and Neuman, 1160.

Lead, southeastern Missouri: Cantwell, 201; Nason, 872.

Tripoli: Plumb, 957.

Physiographic.

Stream piracy, southeast Missouri: Dake, 298. 
Missouri-Continued.

Stratigraphic.

Alexandrian series: Keyes, 659

Devonian, Pike County: Branson, 118.

Northeastern Missouri: Greene, 494.

Southeastern Missouri: Weller and Mehl, 1271.

Paleontology.

Devonian fishes: Branson, 118.

Post-Pliocene shells, Frovidence and Lupus: Sampson, 1026

Missouri River, Pleistocene history: Todd, 1173.

Mollusca. See also Cephalopoda, Castropoda, and Pelecypoda.

Antigua, Tertiary: 'Brown, 130.

California, Eocene horizons: Waring, 1254.

Pleistocene: Oldroyd, 887.

San Juan district: $A$ nderson and Martin, 18.

Temblor Basin: Anderson and Martin, 18.

Martinez fauna, Eocene: Dickerson, 340, 343.

Miocene: Olsson, 888.

Missouri, post-Pliocene: Sampson, 1026.

Neocene, Atlantic Coastal Plain: Olsson, 889. California: Martin, 807.

Oregon, Roseburg quadrangle: Dickerson, 347. Tertiary, California: Anderson and Martin, 1 .

Now Mexico: Cockerell, 249.

New York, Long Island: Gratacap, 491.

Wyoming: Cockerell, 249.

Molluscoidea. See Brachiopoda and Bryozoa.

\section{Molybdenum.}

United States: Hess, 529.

Monocloniús, Alberta: Brown, 135.

\section{Montana.}

Gencral.

Fossil forest, Gallatin Mountains: Knowlton, 693.

Economic.

Big Sandy coal field, Chouteau County: Bowen, 105.

Boulder batholith: Knopf, 688.

Butte district: Bacorn, 27.

paragenesis of ore minerals: Ray, 977.

Clay, northeastern Montana: Bauer, 63.

Cleveland coal field. Blaine County: Bowen, 104.

Coal, eastern Montana: Palmer, 917.

Musselshell-Judith area: Bowen, 103.

western Montana: Palmer, 916.

Cooke City district, Park County: Gardner, 451.

Copper, Butte, genesis: Lawson, 722 .

Dillon quadrangle: Winchell, 1319.

Elliston phosphate field: Stone and Bonine, 1149 .

Iron, Blackfeet Reservation: Stebinger, 1124 .

Judith Mountains, Fergus County: Hoyt, 584.

Lignite, Sheridan County: Bauer, 64.

Marysville district: Goodale, 475.

Niter near Melrose: Richards, 994

Park County: Gardner, 451.

Pine Ridge coal field: Rogers, 1012.

Rolla quadrangle: Lee, 727.

Saltese: Calkins and Jones, 192.

Dynamic and structural.

Boulder batholith: Lawson, 722 .

Sublacustrine glacial erosion: Davis, 324 .
Montana-Continued.

Physiographic.

Glacial Lake Missoula: Stone, 1148.

Glacier National Park: Campbel], 196. glaciers: Alden, 3.

Stratigraphic.

Alexandrian series: Savage, 1031.

Big Sandy coal field, Chotean County: Bowen, 105.

Butte region: Meinzer, 829 .

Cambrian, Burling, 157.

Cleveland coal field, Blaine County: Bowen, 104.

Dillon quadrangle: Winchell, 1319.

Glacier National Park, glaciation: Alden, 2.

Montana group: Stebinger, 1125, 1.126.

Musselshell-Judith area: Bowen, 103.

Pine Ridge coal field: Rogers, 1012.

Rolla quadrangle: Lee, 727.

Sheridan County: Bauer, 64.

Sun River district: Powers and Shimer, 959.

Paleontology.

Albertella fauna: Burling, 157.

Algonkian algal flora: Walcott, 1246.

Ceratopsian dinosaur: Gilmore, $\mathbf{4 6 2 .}$

Sun River district: Powers and Shimer, 059.

Petrology.

Boulder batholith: Knopl, 688 .

Dillon quadrangle: Winchell, 1319.

Mineralogy.

Butte district, parigenesis of ore minerals: Ray, 977.

Underground water.

Butte region: Meinzer, 829 .

Montana group: Stebinger, 1125 .

Moraine Dome: Matthes, 815.

Moorcroft oil field, Wyom ing: Barnett, 40.

Moose River sandstone, Maine: Clarke, 244.

Moropus: Holland and Peterson, 559.

Mount Rainier National Park: Matthes, 812.

Moyiesills, British Columbia: Bailey, 28.

Mud cracks: Moore, 863.

Mud cracks, Nova Scotia: Kindle, 675 .

Mud lumps: Shaw, 1075.

Multituberculata: Broom, 127.

Natural bridges.

Formation: Dake, 298.

Natural gas.

General.

Capillary concentration: Washburne, 1259.

Mud lumps of Mississippi River: Shaw, 1075

Alberta, Calgary field: Ellsworth, 390.

Sheep River district: Dowling, 364 .

Arkansas, Fort Smith-Poteau flold: Smith, 1097.

Illinois, Bond, Macoupin, and Montgomery counties: Blatchley, 100.

Colchester and Macomb quadrangles: Hinds, 543.

Map, United States: Day et al., 330 .

Michigan: Smith, 1108 .

Now York: Newland, 874.

Ohio, Cadiz quadrangle: Condit, 271. 
Natural gas-Continued.

Oklahoma, Cushing field: Buttram,178. east-central: Snider, 1113.

Fort Smith-Poteau field: Smith, 1097.

Glenn field: Smith, 1098.

Ontario: Mickle, 842.

Texas, northern: Nicholson, 875 .

United States: U. S. G. S., 1216.

Utah, Green River field: Lupton, 773.

Washington, Olympic Peninsula: Lupton, 774.

West Virginia, Kanawha County: Krehs and Teets, 697.

Preston County: Hennen and Reger, 527.

Wyoming, Douglas field: Barnett, 41 .

\section{Nebraska.}

Stratigraphic.

Kansan drift deposits: Barbour, 36.

\section{Paleontology.}

Carboniferous eurypterids: Barbour, 38 .

Carboniferous jellyfish: Barbour, 37.

Fungus, Pliccene: Whitford, 1289.

Mammalia, Devils Gulch, Brown County: Barbour, 35

Promerycochœrus, Sioux County: Peterson, 940.

Neva limestone, Oklahoma: Beede, 73.

\section{Nevada.}

Economic.

Alunite, Bovard: Schrader, 1048.

Battle Mountain district, Nevada: Bandmann, 34.

Copper, Ely: Whitman, 1290.

Fairview district. Greenan, 493.

Magnesite: Gale, 448.

Platinum-gold lode deposit, southern Nevada: Knopf, 689.

Potash tests, Columbus Marsh: Gale, 445.

Rochester district, Nev.: Schrader, 1048.

Tonopah district: Balliet, 30 .

Yellow Pine district, Clark County: Hill, 538.

Zinc, Yellow Pine district: Hill, 538.

Physiographic.

Lake Lahontan: Jones, 629; Snyder, 1115.

Stewart and Ione valleys: Buwalda, 183.

Stratigraphic.

Fairview district: Greenan, 493.

Lake Lahontan, geologic history: Jones, 629.

Rochester district: Schrader, 1048.

Stewart and Ione valleys: Buwalda, 183.

Paleontology.

Mammalia, Tertiary: Merriam, 833.

Proboscidean tooth, Truckee beds: Buwalda, 182.

Triassic fauna: 1102.

Mineralogy.

Rochester district: Schrader, 1048.

Steamboat Springs: Jones, 630.

Wurtzite, Goldfield: Ransome, 974 .

\section{New Brunswick.}

\section{Economic.}

Building stone: Parks, 920.

Clay and shale deposits: Keele, 644.

Moncton area: Wright, 1349.

St. John area: Hayes, 523.
New Brunswick-Continued.

Dynamic and structural.

Coastal subsidence: Goldthwait, 473.

Stratigraphic.

Cambrian: Matthew, 816 .

Devonian, Dalhousie: Clarke, 244.

Moncton area: Wright, 1349.

St. John area: Hayes, 523.

St. John, fern ledges: Stopes, 1150.

Paleontology.

Cambrian: Matthew, 816 .

Carboniferous flora, St. John: Stopes, 1150.

Devonian, Dalhousie: Clarke, 244.

\section{Newfoundland.}

Economic.

Manganese: Dale, 299

Wabana iron ore: Hayes, 524.

Stratigraphic.

Algonkian, southeast Newfoundland: Buddington, 149.

Cambrian: Matthew, 816 .

Cambrian and Ordovician, southeastern Newfoundland: Van Ingen, 1223.

table: Van Ingen, 1222.

Paleontology.

Cambrian and Ordovician, southeastern Newfoundland: Van Ingen, 1223.

\section{New Hampshire.}

Economic.

Mica, Grafton: Pulsifer, 966.

Physiographic.

White Mountains, Presidential Range, graded upland: Goldthwait, 472 .

Stratigraphic.

Moraine, Jackson: Foshay, 434.

Petrology.

Hanover, schist, sedimentary origin: Merritt, 837.

New Jersey.

General.

Report of State geologist, 1913: Kümmel, 699.

Economic.

Mineral industry, 1913: Twitchell, 1192.

Raritan quadrangle: Bayley et al., 66 .

Dynamic and structural.

Coast changes: Johnson and Smith, 623.

Physiographic.

Raritan quadrangle: Bayley et al., 66.

Terraces, Delaware River: Winchell, 1323.

Stratigraphic.

Geologic map: Lewis and Kümmel, 747 .

Gneisses, Highlands: Fenner, 413.

Highlands, pre-Cambrian sedimentary rocks: Bayley, 65 .

Lockatong formation, Triassic: Hawkins, 520.

Raritan quadrangle: Bayley et al., 66 .

Triassic: Tlawkins, 520 .

Palcontology.

Cretaceous lignites, Cliffwood: Holden, 557.

Petrology.

Gneisses, Highlands, origin: Fenner, 412, 413.

Mineralogy.

Babingtonite, Passaic County: Fenner, 414, 415. Hodgkinsonite, Franklin Furnace: Palache and Schaller, 911. 


\section{New Mexico.}

Economic.

A pache district: Wade, 1240.

Burro Mountain district: Bush, 170 .

Florida Mountains: Becker, 69 .

Gallup Basin: Kirk, 682.

Organ Mountain district: Welsh, 1274.

Petroleum, Dayton: Richardson, 998.

Pinos Altos district: Wade, 1241.

Sierra Blanca coal field: Wegemann, 1268.

Dynamic and structural.

Bowlders in gravel deposits: Rich, 993.

Faulting, Luna County: Darton, 312.

Physiographic.

General: Huntington, 598 .

Stratigraphic.

Cretaceous, western New Mexico: Winchester, 1324.

Eocene faunal horizons: Granger, 485.

Florida Mountains: Becker, 69 .

Gallup Basin: Kirk, 682.

Red beds: Case, 208; Darton, 311, 313.

San Juan Basin: Sinclair, 1092.

Paleocene deposits: Sinclair and Cranger, 1093.

Sierra Blanea coal field: Wegemann, 1268.

Paleontology.

Tertiary Mollusca: Cockerell, 249.

Petrology.

Eocene formations, Rocky Mountains, petrographic characters: Johannsen, 615 .

Mineralogy.

Meteorite, Glorieta: Hills, 542.

Underground water.

Luna County: Darton, 310.

New World district, Montana: Gardner, 451.

\section{New York.}

General.

Director's report: Clarke, 243.

Hudson Rives, geology: Kunz, 700.

Lester Park: Clarke, 248.

Economic.

Iron, magnetites, $\Lambda$ dirondacks: St. Clair, 1020.

Mining industry, 1913: Newland, 874.

North Creek quadrangle, Warren County: Miller, 850.

Dynamic and structural.

Grieisses, origin: Berkey, 78.

Physiographic.

Gencral: Miller, 840.

Eastern central New York: Rich, 991.

Hudson Gorge: Crosby, 286.

Long Island: Fuller, 441.

Serpentine stock, Staten Island: Crosby, 287.

Syracuse quadrangle: Hopkins, 571.

Stratigraphic.

General: Clarke, 243.

Adirondacks: Kemp, 651.

Attica quadrangle: Luther, 775 .

Cataract formation: Schuchert, 1054.

Depew quadrangle: Luther, 775.

Eastern New York: Clarke, 244.

Erie County: Houghton, 577.

Geological history: Miller, 849.

Long Island: Fuller, 441.

Lorraine: Foerste, 428.
New York-Continued.

Stratigraphic-Continued.

Manhattan schist: Fettke, $\mathbf{4 2 0}$

Medina formation: Schuchert, 1054.

Medina sandstone: Kindle, 680 .

New York City: Berkey and Healy, 79.

North Creek quadrangle, Warren County: Miller, 850.

Saratoga Springs: Cushing and Ruedemann, 296.

Serpentine stock, Staten Island: Crosby, 287.

Shawangunk conglomerate, Ulster County: Brown, 128.

Syracuse quadrangle: Hopkins, 571.

Paleontology.

Castoroides, Madison County: Smith, 1094.

Erie County: Houghton, 577.

Homocrinus: Kirk, 683 .

Lorraine fauna: Foerste, 428.

Mammalia, Onondaga Lake: Smith, 1096.

Oriskany fauna: Clarke, 244.

Siluric gastropods: O'Connell, 884.

Syracuse quadrangle: Smith, 1095.

Tertiary shells, Long Island: Gratacap, 491.

Petrology.

Adirondack region: Miller, 851 .

Magmatic differentiation and assimilation in Adirondack region: Miller, 851 .

Manhattan schist: Fettke, 420.

Syracuse, peridotite dikes: Clark, 234.

Mineralogy.

Manhattan Island, Broadway: Manchester, 804.

Underground water.

Saratoga mineral springs: Clarke, 243.

Saratoga mineral waters, origin: Ruedemann, 1019.

Niagara Gorge, time measures: Taylor, $\mathbf{1 1 6 1}$.

Nicaragua.

Dynamic and structural.

Masaya: Sapper, 1029.

Nickel.

Ontario, Sudbury district: Howe, 583; Thomas, 1166.

origin: St. Clair, 1021.

United States: Hess, 529 .

Niter.

Montana, Melrose: Richards, 994.

Nomenclature. Sec also under Stratigraphic.

Diastrophic disturbances: Chamberlin, 209.

Eruptive, use of term: Lahee, 701.

Faults: Stevens, 1137.

Fusulinas: Girty, 463.

Minerals: Wherry, 1280 .

Pre-Cambrian: Sederholm, 1065.

\section{North Carolina.}

General.

Chapel Hill: Smith, 1104.

Economic.

Coal, Dan River field: Stone, 1146.

Mining industrý, 1911-12: Pratt, 960.

Stratigraphic.

Chapel Fill: Smith, 1104, 1105.

Palcontology.

Neocene Mollusca: Olsson, 880 .

North Creek quadrangle, N. Y.: Miller, 850. 


\section{North Dakota.}

General.

Survey report: Leonard, 736.

Economic.

Cannonball River lignite field: Lloyd, 758.

Clay: Babcock, 26.

Coal: Babcock, 26.

South central North Dakota: Leonard, 737.

Physiographic.

Devils-Stump Lake region: Simpson, 1090. Cannonball River lignite field: Lloyd, 758. South central North Dakota: Leonard, 737. Standing Rock Indian Reservation: Calvert $e t$ al., 193.

\section{Northwest Territories.}

General: Tyrrell, 1196.

Coppermine River: Douglas, 359; Sandberg, 1027.

Economic.

General: Tyrrell, 1196.

Coppermine River: Sandberg, 1027.

Petrology.

Coppermine River: Graton, 492.

\section{Nova Scotia.}

Economic.

Arisaig-Antigonish district: Williams, 1300.

Building stone: Parks, 920 .

Clay, Lunenburg County: Faribault, 404.

Clyburn Valley, Cape Breton Island: Wright, 1350.

Gold, Oldham district: Faribault, 403.

Greenfield and Liverpool areas: Faribault, 402.

Iron: Woodman, 1330.

Cape Breton: Lindeman, 751.

Lunenburg County, New Ross: Wright, 1348.

Pleasant River Barrens: Faribault, 406.

Port Mouton area, Queens County: Faribault, 405.

Physiographic.

Arisaig-Antigonish district: Williams, 1300 .

Stratigraphic.

Arisaig-Antigonish district: Williams, 1300.

Cambrian, Cape Breton Island: Matthew, 816 .

Clyburn Valley, Cape Breton Island: Wright, 1350.

Glaciation: Goldthwait, 471.

Greenfield and I,iverpool areas: Faribault, 402.

Joggins Carboniferous section: Bell, 77.

Lunenburg County, Pleasant River Barrens: Faribault, 406.

Port Mouton area, Queens County: Faribault, 405.

Riversdale-Union and Windsor formations: Hyde, 601.

Windsor-Pennsylvanian section, Strait of Canso Hyde, 602.

Paleontology.

Cambrian, Cape Breton Island: Matthew, 816: Petrology.

Ohio.

Arisaig-Antigonish district:" Williams, 1300.

Economic.

Cadiz quadrangle, oil and gas: Condit, 271.

Coal: Ray, 975.

Hocking Valley coal field: Burroughs, 162.

Pittsburgh coal bed: Burroughs, 163.
Ohlo-Continued.

Dynamic and structural.

Erosion, Fayette County: Napper, 871.

Physiographic.

Craighton Lake (glacial): Leverett, 742.

tilted shore lines: Hubbard, 586 .

Drainage changes: Coffey, 258.

southwestern Ohio: Fenneman, 411.

Locust Grove esker: Thompson, 1168.

Stratigraphic.

Berea sandstone in eroded Cleveland shale: Burroughs, 160 .

Finger Lake bed, Ashland and Wayne counties: Hubbard, 587.

Mississippian unconformities and conglomerates: Lamb, 705 .

Richmond, upper: Shideler, 1082.

Waverly formation: Morse and Foerste, 867 .

Paleontology.

Cystoidea: Foerste, 429.

Starfish, Richmond, Adams County: Williams, 1305.

Oil, See Petroleum.

Oil shales.

Colorado, northwestern: Woodruff and Day, 1333.

New Brunswick, Moncton area, Albert mines: Wright, 1349.

Utah, northeastern: Woodruff and Day, 1333.

\section{Oklahoma.}

General.

Director's report: Shannon, 1074.

Economic.

Cushing oil and gas field: Buttram, 178

map: Okla. G. S., 886.

Fort Smith-Poteau gas field: Smith, 1097.

Glenn oil and gas pool: Smith, 1098 .

Lead, Arbuckle Mountains: Becker, 71.

Mineral resources: Shannon, 1074.

Oil and gas, east-central: Snider, 1113.

Tripoli: Plumb, 957.

Volcanic dust: Buttram, 177.

Zinc, Arbuckle Mountains: Becker, 71.

Stratigraphic.

Cushing oil and gas field: Buttram, 178.

East-central Oklahoma: Snider, 1113.

Fort Smith-Poteau gas field: Smith, 1097.

Glenn, oil and gas pool: Smith, 1098.

Grandfield district: Munn, $\mathbf{8 6 9}$.

Mississippian, northeastern Oklahoma: Snider, 1113.

Neva limestone: Beede, 73.

Oolites, Chimneyhill formation: Reeds, 986.

Underground water.

Canadian River, North Fork, ground water near Oklahoma City: Schwennesen, 1060.

Ground water, Enid: Schwennesen, 1059.

Oligocene. See Tertiary.

Ontario.

General.

Report, 1914, Bureau of Mines: Gibson, 456.

Economic.

Cobalt: Bell, 74 .

Gold, Porcupine district: Hore, 575

Michipicoten district: Means, 827 .

Swastika area: Bruce, 142 . 
Ontario-Continued.

Economic-Continued.

Kirkland Lake district: Hardinge, 513; Spearman, 1116.

Kirkland Lake and Swastika gold areas: Burrows and Hopkins, 164.

Magnetite, Calabogie, Renfrew County: Lindeman, 749.

Mica: De Schmid, 334.

Moose Mountain iron district: Lindeman, 750.

Natural gas, composition: Mickle, 842.

Nickel-copper, Sudbury: Hore, 574 .

Onaping sheet: Collins, 268.

Porcupine district: Dobbs, 356.

Southeastern: Miller and Knight, 848.

Sudbury deposits, classification: Coleman, 261.

Sudbury nickel deposits: Howe, 583.

Sudbury nickel-copper deposits, origin: Hore, 574.

Sudbury ores, oritin: St. Clair, 1021.

Sudbury nickel district: Thomas, 1166.

Timiskaming district: Burrows and Hopkins, 164.

Dynamic and structural.

Carbonzceous schists, Lake of the Woods: Greenland, 495.

Ripple-marked Huronian quartzite, Cobalt: Hore, 575.

Ripple marks, Ottawa: Kindle, 681 .

Physiographic.

Shore lines, St. Joseph Island, Lake Huron: Leverett, 743 .

Stratigraphic.

Cataract formation: Schuchert, 1054

Don River glacial deposits, Toronto: Wright, 1844.

Huronian, Timiskaming region: Collins, 270.

Kirkland Lake and Swastika gold areas: Burrows and Hopkins, 164.

Lake Simcoe area: Johnston, 626.

Medina formation: Schuchert, 1054.

Niagara escarpment, southwestern Ontario: Williams, 1303.

Onaping sheet: Collins, 268.

Oriskany sandstone and Ohio shale: Kindle, 677.

Porcupine district: Dobbs, 356 .

Pre-Cambrian, Lake Huron region; Coleman, 264.

southeastern: Miller and Knight, 848 .

Rainy Lake: Lawson, 721.

Rainy River district, Pleistocene: Johnston, 627.

Silurian, Manitoulin Island: Williams, 1301. southwestern Ontario: Williams, 1304.

Southwestern Ontario: Stauffer, 1123.

Sudbury region: Coleman, 264; Collins, 269.

Sudbury series: Coleman, 262.

Thedford: Williams, 1302.

Timiskaming district: Burrows and Hopkins, 164.

Toronto region: Coleman, 263.

glacial deposits: Wright, 1344.

Trenton group: Raymond, 980.

Paleontology.

Brockocystis: Foerste, 429 .

Cryptophragmus: Raymond, 983.

Thresherodiscus: Foerste, 429.
Ontario-Continued.

Petrology.

Pre-Cambrian, Lake Huron region: Coleman, 264.

Rainy Lake: Lawson, 721.

Sudbury field, Levack: Brackenbury, 114.

Sudbury nickel deposits: B.owe, 583.

Mineralogy.

Temiskamite: Walker, 1248.

Oolite.

Origin: Brown, 141; Vaughan, 1230; Wieland, 1294.

\section{Ordovician.}

Stratigraphy.

Alaska-Yukon boundary: Cairnes, 187.

Anticosti Island: Twenhofel, 1190.

British Columbia, East Kootenay district: Schofield, 1041.

Field area: Allan, 5 .

Selkirk and Purcell Mountains: Daly, 306.

California, Inyo and White Mountains: Knopf, 686.

Illinois, Bond, Macoupin, ànd Montgomery counties: Blatchley, 100.

La Salle: Cady, 185.

northwestern: $\mathrm{Cox}, 278$.

Indiana, Tanners Cfeek: Cumings and Galloway, 295.

Kentucky, central: Foerste, 426.

Georgetown quadrangle: Miller, 843.

north central: Foerste, 427.

Wayne County: Munn, 869 .

Levis: Raymond, 982.

Manitoba: MacLean and Wallace, 796.

Minnesota: Grout and Soper, 502.

New Brunswick, St. John area: Hayes, 523.

Newfoundland, Conception and Trinity bays: Van Ingen, 1222.

New Jersey, Raritan quadrangle: Bayley et al., 66.

New York, Lorraine: Foerste, 428.

Saratoga Springs region: Cushing and Ruedemann, 296.

Nova Scotia, Arisaig-Antigonish district: Williams, 1300.

Ontario, Lake Simcoe area: Johnston, 626.

Ottawa, ripple marks: Kindle, 681.

Trenton group: Raymond, 980.

Pennsylvania, Coatesville quadrangle: Bliss and Jonas, 101.

Quebec, Anticosti Island: Twenhofel, 1190.

Levis: Raymond, 981.

Lorraine: Foerste, 428 .

St. Hilaire and Rougemont mountains: O'Neill, 892.

southern: Dresser, 367; Harvie, 515.

Trenton group: Raymond, 980.

Richmond, upper, Cincinnati region: Shideler, 1082.

Tennessee, Perry County: Wade, 1239.

Waynesboro quadrangle: Jrake, 366 .

Texas, Van Horn quadrangle: Richardson, 999.

Vermont, Bennington: Gordon, 476.

Greensboro: Richardson and Turner, 996.

Hardwick: Richardson et al., 997.

Woodbury: Richardson ct al., 997.

Virginia, A bingdon quadrangle: Stose, 1152. southwestern: Powell, 958. 
Ordovician-Continued.

Paleontology.

Agelacrinidæ: Foerste, 429.

Anticosti Island faunas: Twenhofel, 1190.

Arctic: Schuchert, 1055.

Brachiopoda, sedimentary relations: Burling, 158.

Cryptophragmus: Raymond, 983.

Indiana, Tanners Creek: Cumings and Galloway, 295.

Iowa, Graf: Thomas, 1165 .

Isotelus gigas, ontogeny: Raymond, 979.

Kentucky: Foerste, 424.

Georgetown quadrangle: Miller, 843.

Lepadocystinæ: Foerste, 429.

Ievis: Raymond, 982.

Lorraine faunas, New York and Quebec: Foerste, 428 .

Ohio, Adams County, starfish: Williams, 1305. Quebec, Levis: Raymond, 981.

Rogers Gap fauna, Kentucky: Foerste, 427.

Ore deposits, origin. For ore deposits in general, see Economic (general).

General: Bacorn, 27; Hatch, 516; Lawson, 722, 726; Lindsley, 755; Maclaren, 795; Nishihara, 879 .

Asbestos: Hopkins, 568 .

$\Lambda$ scending secondary enrichment: Turner and Rogers, 1188 .

Boulder batholith: Knopf, 688 .

British Columbia, Quadra Island: Cairnes, 191.

Carnotite, Utah and Colorado: Hess, 528.

Colorado, Gitpin County: Becker, 68.

Copper: Bacorn, 27; Tolman and Clark, 1176.

Arizona, A jo district: Joralemon, 634.

Grand Gulch region: IIIll, 539.

Superior: Ransome, 973.

California, Bully Fill district: Boyle, 113.

Plumas County: Turner and Rogers, 1188. enrichment of sulphide ores: Clark, 237.

Idaho, Mackay: Umpleby, 1208, 1209.

Maryland, Frederick County: Butler and McCaskey, 176.

Montana, Butte: Lawson, 722.

Nevada, Ely: Whitman, 1290.

Pennsylvania, South Mountain region: Bevier, 89.

relation of sulphides: Thompson, 1167.

Sudbury, Ontario: Hore, 574.

Deposition by meteoric waters: Lawson, 725 .

Diffusion of ore deposits: Lawson, 726.

Electric activity in ore deposits: Wells, 1273.

Formation in depth: Fermor, 419.

Garnet zones, origin: Lindgren, 752.

Gold, deposition in nature: Lenher, 735.

enrichment: Mann, 805 .

Ontario, Kirkland Lake district: Stearman, - 1116.

Michipicoten district: Means, 827.

Porcupine district: Hore, 575 .

Timiskaming district: Burrows and Hopkins, 164 .

Graphite: Stansfield, 1119.

Hydrothermal alteration of granite: Moore, 864.
Ore deposits, origin-Continued.

Iron: Earle, 380.

Colorado, Caribou: Bastin, 58.

Leadville: Argall, 20.

Nova Scotia: Woodman, 1330.

Paleozoic interbedded deposits: Earle, 380.

titaniferous ores: St. Clair, 1020.

Lead, Mlinois, northwestern: Cox, 278.

Mexico, Zimapan (Hidalgo): Lindgren and Whitehead, 754.

Mineralizing solutions, intrusive pressure: Stevens, 1138.

Mine-water composition: Lane, 715.

Missouri, Joplin ores: Siebenthal, 1086.

Nevada, Fairview district: Greenan, 493.

Newer theories of ore deposition: Kemp, 650 .

New Mexico, Pinos Altos district: Wade, 1241.

Nickel, Ontario, Sudbury district: Hore, 574; Howe, 583; St. Clair, 1021.

Oregon, southwestern: Winchell, 1320.

Sumpter quadrangle: Pardee and Hewett, 918.

Persistence of ore in depth: Maclaren, 795; Rickard, 1000.

Phosphate, South Carolina: Rogers, 1013.

Quicksilver, California: Veatch, 1236.

Secondary limestones: Fermor, 419.

Silver enrichment: Palmer, 913.

Sulphide enrichment: Nishihara, 879; Rogers, 1010; Tolman, 1174, 1175; Tolman and Clark, 1176.

carbonates in: Nishihara, 879.

Superficial diffusion: Penrose, 928.

Utah, San Francisco district: Butler, 172.

Zinc, Mlinois, northwestern: Cox, 278.

Utah, Tintic district: Loughlin, 765 .

Ore shoots. See Economic geology, and Oro deposits, origin.

\section{Oregon.}

Economic.

Baker district: Grant and Cady, 487.

Building stone: Parks, 919.

Coal, southwestern Oregon: Winchell, 1320.

Squaw Creek Basin, Coos County: Williams, 1298.

Copper, southwestern Oregon: Winchell, 1320. Eden Ridgecoal field, Coos County: Lesher, 739 . Gold, southwestern Oregon: Winchell, 1320 .

Jackson and Josephine counties: Winchell, 1320.

John Day region: Collier, 266.

Limestone: Williams, 1299.

Northeastern Oregon: Swartley, 1155.

North western Oregon: Washburne, 1257.

Southwestern Oregon: Diller, 352.

Sumpter quadrangle: Pardee and Hewett, 918. Stratigraphic.

Baker district: Grant and Cady, 487.

Eden Ridge coal field, Coos County: Lesher, 739.

Eocene: Arnold and Hannibal, 22.

Jackson and Josephine counties: Winchell, 1320.

John Day region: Collier, 266.

Northwestern Oregon: Washburne, 1257.

Oligocene: Anderson, 17. 
Oregon-Continued.

Stratigraphic-Continued.

Southwestern Oregon: Diller, 352.

Sumpter quadrangle: Pardee and Hewett, 918.

Palcontology.

Roseburg quadrangle: Dickerson, 347 .

Petrology.

Jackson and Josephine counties: Winchell, 1320.

Underground water.

General: Van Winkle, 1228.

Mineral waters, southwestern Oregon: Winchell, 1320.

Organ Mountain district, New Mexico: Welsh, 1274. Orogenic epochs: Blackwelder, 92.

\section{Orogeny.}

Gencral: Barrell, 43-45.

Mechanics of formation of arcuate mountains: Hobbs, 546.

Orogenic epochs: Blackwelder, 92.

Paleozoic orogenic movements, periodicity: Chamberlin, 209.

Post-Paleozoic: Keyes, 660 .

Rocky Mountains: Schofield, 1044.

Sierra Nevada Mountains: Alling, 16.

Oscillation. See Changes of level.

Ostracoda. See Crustacea.

Owens Basin, Cal.: Gale, 449.

Ozarkian seaweeds and oolites: Wieland, 1294.

Paint. See Mineral paints.

\section{Paleobotany.}

Alaska, Cape Lisburne, Jurassic flora: Knowlton, 690 .

Algonkian algal flora: Walcott, 1246.

Arizona, fossil trees: Briscoe, 119.

British Columbia, East Kootenay, Pleistocen $\theta$ llora: Hollick, 561.

Callixylon: Elkins and Wieland, 386.

Canada: Wilson, 1317, 1318 .

Collections of New York Botanical Garden: Hollick, 560 .

Colorado, Florissant flora: Cockerell, 255.

Cordaitean wood, Indiana: Elkins and Wieland, 386.

Cretaceous, Upper, and Eocene, South Carolina and Georgia: Berry, 80.

Cycads: Wieland, 1295.

Date palm fruit, Texas: Berry, 83.

Dicotyls, origin: Wieland, 1296.

Eocene flora, southeastern North America: Berry, 86.

Forests, fossil, Yellowstone National Park: Knowlton, 692.

Fungus, Nebraska Pliocene: Whitford, 1289.

Jurassic flora, Alaska: Knowlton, 690.

Kentucky, Waverly: Scott and Jeffrey, 1061.

Lignites, Cretaceous, New Jersey: Holden, 557.

Leaves: Humphreys, 594 .

Maryland, Cretaceous floras: Berry, 84.

New Brunswick, St. John, Carboniferous flora: Stopes, 1150.

Nipadites, Eocene: Berry, 81.

Panama Canal Zone: IBerry, 82.

Plants, roof of Pittsburgh coal: Grier, 500.
Paleobotany-Continued.

Pleistocene, Southern States: Berry, 88.

Psaronius, Iowa: Farr, 407.

Resins in Paleozoic plants: White, 1283, 1284.

Trapa: Berry, 85.

Wyoming, Clarks Fork Basin, 'Tertiary seeds: Cockerell, 255.

\section{Paleoclimatology.}

General: Barrell, 51; Huntington, 598, 599; Schuchert, 1051, 1056.

Solar hypothesis of climatic changes: Huntington, 59.9 .

Paleographic maps.

Appalachian geosyncline, close of Chemung: Barrell, 50 .

Cretaceous and Tertiary: Baker, 29.

Glacial periods: Schuchert, 1051.

Medina-Cataract-Brassficld: Schuchert, 1054.

Paleogeography. See also Geologic history, Paleoclimatology, and Pallogeographic maps.

General: Grabau, 483.

Alexandrian series: Keyes, 650.

Circumcontinental growth: Chamberlin, 213.

Cretaceous, Rocky Mountain region: Lee, 728.

Devonian: Barrell, 50 .

early: Clarke, 244.

Silurian: Schuchert, 1054.

Alexandrian series: Keyes, (559.

Paleometeorology. Sec Paleoclimatology.

Paleontology (general). See also the classes of animals and Paleobotany. For stratigraphic see the different systems. For regional see names of States.

Color markings, Gastropoda: Roundy, 1018.

Convergent evolution: Gregory et al., 499.

Sedimentary relations, Cambrian and Ordovician: Burling, 158.

Textbook: Shimer, 1083.

Paleozoic (undifferentiated).

British Columbia, Boundary district: LeRoy 738.

Oregon, southwestern: Diller, 352; Winchell, 1320.

Washington, northeastern: Bancroft, 31 .

Wyoming, Lincoln County: Schultz, 1058.

\section{Panama.}

Dynamic and structural.

Earthquakes, Los Santos: MacDonald and Johnston, 789.

Physiographic.

Los Santos: MacDonald and Johnston, 789.

Stratigraphic.

Los Santos: MacDonald and Johnston, 789.

Paleontology.

Plants: Berry, 82.

Panamint Valley, California: Gale, 449.

Paradoxides, ontogeny: Raymond, 978.

Paragenesis of minerals.

Harney Peak region, South Dakota: Ziegler; 1354.

Montana, Butte district: Ray, 977.

Zine minerals, Tintic district, Utah: Loughlin, 765.

Patagonia district, Arizona: Probert, 964.

$$
97921^{\circ}-\text { Bull. } 617-15-9
$$


Peat.

General.

Origin and formation: Davis, 314.

Florida: Seltards, 1067.

United States: Davis, 315 .

Pelecypoda. See also Mollusca.

Exogyra: Stephenson, 1128.

Triassic, marine: Smith, 1102.

Unios, Triassic, Massachusetts: Troxell, 1183.

Pelycosauria: 'Broom, 128.

Pennsylvania.

Report, Survey: Pa. G. S., 927.

Economic.

Broadtop coal field: Gardner, 452. map: Gardner, 453.

Carnotite, Carbon County: Wherry, 1282.

Mauch Chunk: Wherry, 1278.

Coal: Burrows, 163 .

northern antbracite field: Gleason, 464.

Coatesville quadrangle, Pennsylvania: Bliss and Jonas, 101.

Copper, South Mountain region: Bevier, 89.

Economic minerals: Brown and Ehrenfeld, 131.

Limestone: Frear, 436.

Pittsburgh coal bed: Burroughs, 163.

Pocono coals: Halberstadt, 510.

Physiographic.

Coatesville quadrangle, Pennsylvania: Bliss and Jonas, 101.

Glacial ice dam, Warren: Wright, 1345.

Quaker Lake, Susquehanna County: Wilson, 1312.

Stratigraphic.

Broadtop coal field: Gardner, $\mathbf{4 5 2 .}$

map: Gardner, 453.

Coatesville quadrangle, Pennsylvania: Bliss and Jonas, 101.

Glacial dam in Allegheny River: Wright, 1345.

Lockatong formation, Triassic: Hawkins, 520.

Quaternary deposits, Wyoming valley: Dar. ton, 309.

Triassic: Hawkins, 520.

Wissahickon mica gneiss, Doe Run-Avondale district: Bliss and Jonas, 101.

Paleontology.

Plants, roof of Pittsburgh coal: Grier, 500 .

Rectogloma: Van Tuyl and Berckhemer, 1227.

Petrology.

Coatesville quadrangle, Pennsylvania: Bliss and Jonas, 101.

Oolite, siliceous: Brown; 141.

Mineralogy.

General: Brown and Ehrenfeld, 131.

Axinite, Delaware County: Wherry, 1281.

Beraunite, Northampton County: Wherry, 1281.

Pennsylvanian. See Carboniferous.

Pentremites. See Blastoidea.

Permian. See Carboniferous.

Permian glaciation: Huntington, 599.

Petrogenesis: Daly, 305.

\section{Petroleum.}

General: Day, 327

Capillary concentration: Washburne, 1259.

Formation and accumulation: Dumble, 372 .

Fossil wood, relationship to oil: Stuart, 1154.

Origin: Coste, 277; Höfer, 553.

Mexico: Ordónez, 893.

Rock disturbances theory: Coste, 277.

Alaska, Yakataga district: Maddren, 798.

Alberta, Calgary field: Ellsworth, 390 .

Sheep River district: Dowling, 364.

California: $\Lambda$ rnold and Garfias, 21 .

California oil fields, anticlinal dome structure: Hager, 507.

faulting: Hager, 508 .

unconformities and overlap: Hager, 509.

Colorado, De Beque field: De Beque, 331.

Illinois: Wheeler, 1277 .

Bond, Macoupin, and Montgomery counties: Blatchley, 100.

Colchester and Macomb quadrangles: Hinds, 543.

Crawford and Lawrence counties: Blatchley, 98.

Plymouth field: Blatchley, 99.

Indiana, Sullivan County: Barrett, 53.

Kentucky: Hoeing, 554 .

Monticello quadrangle: Munn, 869 .

Wayne County: Munn, 869.

Map, United States: Day et al., 330.

Mexico: Ordoñez, 893.

Michigan: Smith, 1108

Saginaw field: Smith, 1107.

New Mexico, Dayton: Richardson, 998.

New York: Newland, 874

Ohio, Cadiz quadrangle: Condit, 271.

Oklahoma, Cushing field: Buttram, 178.

east-central: Snider, 1113.

Glenn field: Smith, 1098.

Oregon, northwestern: Washburne, 1257.

Texas, northern: Nicholson, 875 .

Utah, Green River field: Lupton, 773.

Washington, Olympic Peninsula: Lupton, 774

West Virginia, Kanawha County: Krebs and Teets, 697.

Preston County: Hennen and Reger, 527.

Wyoming, Douglas field: Barnett, 41 .

Lincoln County: Schultz, 1058.

Moorcroft field: Barnett, 40.

Salt Creek field: Trumbull, 1186.

Shoshone River section: Hewett, 534 .

Petrology (general). See also Igneous and volcanic rocks; Technique. For regional see names of States. For rocks described, see list. p. 144

General: Iddings, 603.

A verage igneous rock: Mead, 826

Classification: Cross, 289.

Crystalloblastic order in metamorphism: Lahee, 703.

Determination of common minerals and rocks, tables for: Tarr, 1159

Determination of rocks: Hobbs, 548 .

Effusive and intrusive in the quantitative classification: Lane, 716 . 


\section{Petrology-Continued.}

Eocene formations, Rocky Mountains, petrographic characters: Johannsen, 615.

Petrographic province, chemical relations, representation: Adams, 1.

Petrographic provinces: Iddings, 604.

Petrographic reports: Tomlinson, 1177.

Serpentine: Julien, 635.

Silicates, constitution: Clarke, 238.

Sills and laccoliths: Daly, 305.

Ternary system; diopside, forsterite, silica: Bowen, 107.

\section{Phosphate.}

General: Sellards, 1067, 1070

Origin: Sellards, 1070.

Rocky Mountain deposits: Blackwelder, 94.

Florida: Sellards, 1067, 1070.

Idaho, Georgetown region: Richards and Mansfield, 995 .

Kentucky, central: Focrste, 426.

Montana, Elliston field: Stone and Bonine, 1149, South Carolina: Rogers, 1013.

Southern States: Sellards, 1071.

Tennessec: Barr, 421; Maynard, 824.

south central: Brown, 138; Hook, 567 .

Waynesboro quadrangle: Drake, 366 .

United States: Phalen, 946.

Utah, northern: Peterson, 941

Virginia, southwestern: Stose, 1152.

Wyoming, Lincoln County: Schultz, 1058.

Physiographic (general). For regional see under the various States. See also Drainage changes.

General: Purdue, 971.

Altiplanation: Fakin, 376.

College physiography (textbook): Tarr and Martin, 1158.

Continental forms, origin: Baker, 29.

Stream valleys: Rich, 992.

Textbook: Hopkins, 570 .

Pillow lava, origin: Lewis, 746.

Pinos Altos district, New Mexico: Wade, 1241.

Pisces.

Cestraciont shark, Triassic, California: Bryant, 145.

Devonian, Missouri: Branson, 118.

Kansas, Lawrence: Twenhofel and Dunbar, 1191.

Platysomus, Alberta: Lambe, 710

Scales: Cockerell, 257.

Triassic: Eastman, 381.

Pittsburgh coal bed: Burroughs, 163.

Placers. See also Gold.

British Columbia, Tulameen district: Camsell 197.

Plants, fossil. See Paleobotany.

Platinum.

British Columbia, Tulameen district: Camsell 197.

United States: Day, 328.

Platygonus, Kansas: Peterson, 937.
Platysomus, Alberta: Lambe, 710.

Pleistocene. See Glacial geology; Quaternary.

Pliocene. See Tertiary.

Polar wanderings: Barrell, 51.

Polyzoa. See Bryozoa.

Portland cement. See Cement.

Port Wells district, Alaska: Johnson, 622.

Potash.

California, Death Valley: Gale, 443.

Saline Valley: Gale, 444.

Great Basin lakes: Gale, 442 .

Great Basin region: Young, 1352.

Nevada, Columbus Marsh: Gale, 445.

Texas: Udden, 1202.

United States: Phalen, 945.

Western States: Hance, 511.

Pound quadrangle, Virginia-Kentucky: Butts, 180.

Pre-Cambrian.

General: Schuchert and Barrell, 1057.

Classification: Coleman, 262; Leith, 732; Sederholm, 1065.

Correlation: Miller, 847 .

Nomenclature: Sederholm, 1065.

Sioux quartzite: Keyes, 668.

Sudbury scries: Coleman, 262.

Time-table: Schuchert and Barrell, 1057.

Unconformities: Sederholm, 1063.

Stratigraphy.

Mlaska, international boundary: Cairnes, 186.

Alaska-Yukon boundary: Cairnes, 187.

Arizona, Buckskin Mountains: Blanchard, 96 Grand Canyon district: Noble, 880 .

British Columbia, East Kootenay: Schofield, 1030-1041.

Field area: Allan, 5.

Purcell Range: Schofield, 1042.

Selkirk and Purcell Mountains: Daly, 306.

southeastern: Schofield, 1043.

Canada: Coleman, 262.

Colorado, southwestern: Cross and Larsen, 290.

Georgia, northern: Hopkins, 568 .

Idaho, Mullan: Calkins and Jones, 192.

Iowa: Keyes, 662, 668 .

Lake Superior region: Leith, 732.

Manitoba, Lake Winnipeg region: Moore, 860 .

Massachusetts, Diamond Hill-Cumberland district: Warren and Powers, 1256.

Michigan, Gwinn iron district: Allen, 14.

Little Lake district: Allen and Barrett, 15.

Minnesota: Grout and Soper, 502.

Montana, Dillon quadrangle: Winchell, 1319.

Saltese: Calkins and Jones, 192.

Newfoundland, Conception and Trinity bays: Van Ingen, 1222.

southeastern, Algonkian: Buddington, 149.

New Jersey, Highlands: Fenner, 413. sedimentary rocks: Bayley, 65.

Raritan quadrangle: Bayley et al., 66.

New York, New York City: Berkey and Healy, 79.

North Creek quadrangle: Miller, 850.

Saratoga Springs region: Cushing and Ruedemann, 296. 
Pre-Cambrian-Continued.

Stratigraphy-Continued.

Nova Scotia, Cape Breton Island, Clyburn Valley: Wright, 1350.

Lunenburg County: Faribault, 406. Queens County: Faribault, 405.

Ontario, Kirkland Lake and Swastika gold areas: Burrows and Hopkins, 164.

Lake Huron region: Coleman, 264.

Onaping sheet: Collins, 268.

Rainy Lake: Lawson, 721.

southeastern: Miller and Knight, 848.

Sudbury area: Collins, 269.

Swastika area: Bruce, 142.

Timiskaming region, Huronian: Collins, 270.

Pennsylvania, Coatesville quadrangle: Bliss and Jonas, 101.

Quebec, Bell River region: Wilson, 1314.

Broadback River region: Cooke, 275.

Buckingham area: Wilson, 1315.

Kewagama Lake area: Wilson, 1313.

southern: Harvie, 515 .

Rhode Island, Diamond Hill-Cumberland district: Warren and Powers, 1256.

Texas, Van Horn quadrangle: Richardson, 999.

Vermont, Bennington: Gordon, 476.

Hardwick: Richardson et al., 997.

unconformity: Keith, 648 .

Woodbury: Richardson et al., 997.

Yukon, international boundary: Cairnes, 186.

Klondike district: Bell, 75 .

Paleontology.

Algonkian algal flora: Walcott, 1246.

Precious stones. See also Diamonds; Sapphires; Turquoise.

United States: Sterrett, 1135.

Primates. See Mammalia.

Promerycochœrus, Nebraska: Peterson, 940.

\section{Protozoa.}

Fusulinas, nomenclature: Girty, 463.

Pterosauria: Huene, 591.

\section{Pyrite.}

United States: Phalen, 944.

Quadra Island, British Columbia: Cairnes, 191.

Quaternary. Sce also Glacial geology.

Stratigraphy.

Alaska, Hanagita-Bremner region: Moffit, 854.

Mount St. Elias region: Maddren, 799.

Arizona, Buckskin Mountains: Blanchard, 96.

British Columbia, East Kootenay district: Schofield, 1041.

Nanaimo area: Clapp, 225.

Vancouver Island, southern: Clapp, 227.

California, Inyo, and White Mountains: Knopf, 686.

Mohave Desert: Buwalda, 181; Pack, 902.

San Francisco district: Lawson, 724.

Missouri River: Todd, 1173.

New York, Long Island: Fuller, 441.

North Dakota, south central: Leonard, 737.

Oklahoma, Grandfield district: Munn, 869.

Pennsylvania, Wyoming Valley: Darton, 309.

Quebec, Kewagama Lake area: Wilson, 1313.

Tennessee, Perry County: Wade, 1239.

Texas, Coastal Plain: Deussen, 336.

Van Horn quadrangle: Richardson, 999.
Quaternary-Continued.

Paleontology.

British Columbia, East Kootenay, Pleistocene flora: Hollick, 561 .

California, Pleistocene: Oldroyd, 887.

Iowa, Pleistocene Mammalia: Hay, 522.

Missouri, post-Pliocene Mollusca: Sampson 1026.

Platygcnus, Kansas: Peterson, 937.

Pleistocene flora, Southern States: Berry, 88 .

\section{Quebec.}

General: Clarke, 243.

Broadback River region: Cooke, 275.

Economic.

General: Parks, 921.

Asbestos: Dresser, 368.

Thetford: Woolsey, 1336.

Buckingham area: Wilson, 1315.

Building stones: Parks, 921 .

Clay: Keele, 645 .

Copper: Bancroft, 33 .

Gold, Kewagama Lake area: Wilson, 1313.

Granite, eastern Quebec: Mailhiot, 800.

Iron ores: Dulieux, 371.

Kewagama Lake area: Wilson, 1313.

Mica: De Schmid, 334.

Mining operations, 1913: Denis, 333.

Southern Quebec: Dresser, 367.

Physiographic.

Kewagama Lake ares: Wilson, 1313.

Marine beaches: Goldthwait, 470.

Shore lines, marine, southeastern Quebec: Goldthwait, 469 .

Stratigraphic.

Anticosti Island: Twenhofel, 1190.

Bell River region: Wilson, 1314.

Broadback River region: Cooke, 275.

Buckingham area: Wilson, 1315.

Glacial drift, Magdalen Islands: Goldthwait, 474.

Kewagama Lake area: Wilson, 1313.

Levis: Raymond, 981, 982.

Lorraine: Foerste, 428.

Monteregian Hills: O'Neill, 892.

Montreal region, Pleistocene: Stansfield, 1120.

Mount Royal: Buchan, 148.

Mount Wissick: Kindle, 675 .

Orford area: Harvie, 515.

Pre-Cambrian: Miller and Knight, 848.

Southern Quebec: Dresser, 367. serpentine belt: Harvie, 515.

Trenton group: Raymond, 980.

Paleontology.

Anticosti Island faunas: Twenhofel, 1190.

- Faunal succession, Levis: Raymond; 982.

Levis: Raymond, 981.

Lorraine fauna: Foerste, 428.

Petrology.

Bell River region: Wilson, 1314.

Kewagama Lake area: Wilson, 1313.

Monteregian Hills: O'Neill, 892.

Mineralogy.

Scapolite, Buckingham: Stansfield, 1121.

Quicksilver.

California: Veatch, 1236.

Sonoma County: Palmer, 915

United States: McCaskey, 777. 
Radium.

General: Howard, 581.

Colorado: Bastin, 57; Parsons, 922.

Pennsylvania, Mauch Chunk: Wherry, 1278.

United States: Hess, 529.

Utah: Parsons, 922.

Radium-bearing minerals: Malcolm, 801.

Rainy Hollow district, British Columbia: McConnell, 784.

Rainy Lake, Archean geology: Lawson, 721.

Raritan quadrangle, New Jersey: Bayley et al., 66.

Rectogloma: Van Tuyl and Berckhemer, 1227.

\section{Relief maps.}

Alaska: Brooks, 125.

Colorado, south central: Cross, 288.

Oregon: Swartley, 1155.

\section{Reptilia.}

General: Lull, 769; Williston, 1306.

Alberta, Cretaceous: Lambe, 707.

Dinosauria, Belly River formation: Lambe, $706,708$.

Anchiceratops, Alberta: Brown, 134.

Aræoscelis, Texas, Permian: Williston, 1309.

Archosauria: Huene, 590.

Aspideretes, Belly River formation: Lambe, 709.

Camarasaurus: Mook, 858, 859.

Ceratopsia: Brown, 134.

Corythosaurus, Alberta: Brown, 136.

Cretaceous, Benton, ichthyosaurian: Gilmore, 461.

Diadectes: Broom, 126.

Dinosauria: Huene, 589, 593.

Alberta: Lambe, 706-708.

osteology: Gilmore, 460.

Dinosaur-turtle analogy: Wieland, 1293.

Distribution, etc., Carboniferous: Williston, 1310.

Edaphosaurus: Case, 206.

Leptoceratops, Alberta: Brown, 137.

Lysorophus, Permian, Texas: Huene, 588.

Monoclonius, Alberta: $\cdot$ Brown, 135.

Montana: Gilmore, 462.

ceratopsian dinosaur: Gilmore, $\mathbf{4 6 2 .}$

Pelycosauria: Broom, 128.

Pterosauria: Huene, 591.

Restorations of Permocarboniferous forms: Williston, 1308.

Saurischia: Huene, 592.

Stegosaurus: Gilmore, 460.

Trachodontidæ, classification: Brown, 136.

Triassic: Huene, 592 .

Turtles, Cretaceous, Alberta: Lambe, 709.

Republic district, Washington: Lindgren and Bancroft, 753.

Resins in Paleozoic coals: White, 1283.

\section{Restorations.}

Aræoscelis, Texas, Permian: Williston, 1309.

Archeosigillaria: Clarke, 243.

Brontotherium: Osborn, 897.

Camarasaurus: Mook, 858.

Cephalopoda: Clarke, 243.

Diploceras, Uinta Eocene: Peterson, 935.

Edaphosaurus: Case, 206.

Elephant: Osborn, 898.
Restorations-Continued.

Eotitanops: Osborn, 897 .

Eurypterida: Clarke, 243.

Mastodon: Osborn, 898.

Methods: Osborn, 897.

Permocarboniferous amphibians and reptiles: Williston, 1308 .

Promerycochœrus, Nebraska: Peterson, 940.

Reptilia: Williston, 1306.

Stegosaurus: Gilmore, 460 .

Trachodon: Shimer, 1084 .

\section{Rhode Island.}

Anthracite: Ashley, 23.

Dynamic and structural.

Metamorphism, Narragansett Basin: Lahee, 703.

Stratigraphic.

Cumberland-Diamond Fill district: Warren and Powers, 1256.

Diamond Hill-Cumberland district: Warren and Powers, 1256.

Narragansett Basin: Loughlin and Hechinger, 767.

Petrology.

Diamond Hill-Cumberland district: Warren and Powers, 1256.

Rice Lake gold district, Manitoba: Farding, 512; Wallace, 1251.

Richmond beds of Cincinnati group: Shideler, 1082.

Rigidity of the earth: Michelson, 841 .

Ripple marks.

General: Epry, 396; Kindle, 681.

Cambrian and Ordovician: Kindle, 681.

Huronian quartzite, Cobalt, Ontario: Frore, 575.

Rivers.

Missouri River, Pleistocene history: Todd, 1173.

\section{Road materials.}

Iowa: Beyer and Wright, 90.

Tennessee: Purdue, 970.

Rochester district, Nevada: Schrader, 1048.

Rock slides. See Landslides.

Rocks described. See list, p. 144.

Rocks, structural features.

Carbonaceous schists, Lake of the Woods: Greenland, 495.

Columnar structure in limestone: Kindle, 675.

Interference ripples: Kindle, 674.

Mud cracks: Moore, 863 .

Nova Scotia: Kindle, 675.

Russellville iron district, Ala.: Sawyer, 1033.

Rutile.

United States, eastern: Watson, 1261.

Saginaw oil field, Michigan: Smith, 1107.

Salines.

California, Searles Lake: Dolbear, 357.

southeastern: Gale, 449.

Great Basin region: Young, 1352.

Salt.

California, Saline Valley: Gale, 444.

Manitoba: MacLean and Wallace, 796.

saline springs: Cole, 260 .

Michigan: Cook, 273.

New York: Newland, 874. 
Salt-Continued.

Southern States: Phalen, 949.

United States: Phalen, 946; Schnabel, 1038.

West Virginia, Kanawha County: Krebs and Teets, 697 .

Salt domes, origin: Washburne, 1258.

Salton Sea: MacDougal et al., 791.

Sand. See also Glass sand and Silica. United States: Stone, 1147.

Sandstone. See also Stone, Building stone. Now York: Newland, 874.

San Francisco district, California: Lawson, 724.

San Francisco district, Utah: Butler, 172.

San Francisco folio (193): Lawson, 724.

San Juan district, California: Anderson and Martin, 18.

\section{Saskatchewan.}

Economic.

Beaver Lake mining district: Bruce, 144.

Clay and shale deposits: Ries and Keele, 1006.

Gold, Beaver Lake district: Bruce, 144.

Willowbunch area: Rose, 1017.

Stratigraphic.

Willowbunch area: Rose, 1017.

Saurischia: Huene, 592.

Sawtooth quadrangle, Idaho: Umpleby, 1210.

Searles Lake, Cal.: Gale, 449.

Sedimentation. See also Conglomerates, Erosion. General: Udden, 1203.

Chesapeake Bay, mouth of Choptank River: Hunter, 597.

Classification of sediments: Trowbridge, 1182.

Clastic serliments, mechanical composition: Udden, 1203.

Contemporaneous deformation: Lahee, 704.

Foreset beds and slope deposits: Chamberlin, 212.

Limestone, origin: Walcott; 1246.

Parting in coal bed: Rogers, 1014.

Shawangunk conglomerate, 'Ulster County. N. Y.: Brown, 128.

Transportation of débris by running water: Gilbert, 458.

Segmentation of earth: Chamberlin, 214.

Seismology. See also Earthquakes.

General: Gutiérrez Lanza, 503.

Earthquake sea waves: Reid, 990.

Perceptibility of weak earthquakes: Wood, 1327.

Seismographic records, Harvard: Woodworth, 1335.

\section{Selenium.}

United States: Hess, $\mathbf{5 2 9}$.

Serpentine: Julien, 635.

Shale.

Alberta: Ries and Keele, 1006.

British Columbia: Ries and Keele, 1006.

Canada, western provinces: Ries, 1001, 1005.

Minnesota: Grout and Soper, 502 .

New Brunswick: Keele, 644 .

Saskatchewan: Ries and Keele, 1006.

Shawangunk conglomerate, Ulster County, N. Y.: Brown, 128.

Shelf seas: Chamberlin, 210.
Shinumo quadrangle, Arizona: Noble, 880.

Shore lines. See also Beaches; Terraces.

General: Johnson, 620.

Craigton Lake, tilted shorel ines: Hubbard, 586.

Lake Agassiz: Leverett, 744.

Quebec, southeastern: Goldthwait, 469.

Silica.

United States: Katz, 637.

Siliçates, natural, constitution: Clarke, 238.

Silurian. For Lower Silurian see Ordovician.

Stratigraphy.

Alaska, international boundary: Cairnes, 186.

Alaska-Yukon boundary: Cairnes, 187.

Alexandrian series: Keyes, 659; Savage, 1031.

Anticosti Island: Twenhofel, 1190.

Arctic regions, Ellesmere Land: Holtedahl, 562.

British Columbia, Field area: Allan, 5.

Cataract formation: Schuchert, 1054.

IIlinois, La Salle: Cady, 185.

northwestern: Cox, 278.

Kentucky, Wayne County: Munn, 869.

Maine, Eastport quadrangle: Bastin and Williams, 60.

Manitoba: Kindle, 676; MacLean and Wallace, 796.

Medina formation: Schucherc, 1054.

Michigan: Cook, 273.

Wayne County: Sherzer, 1081.

New Jersey, Raritan quadrangle: Bayley et al., 66.

New York, Attica-Depew quadrangles: Luther 775.

Erie County: Houghton, 577.

Medina sandstone: Kindle, 680 .

Niagara region: Kindle, 680 .

Syracuse quadrangle: Hopkins, 571.

Ulster County: Brown, 128.

Nova Scotia, Arisaig-Antigonish district: Williams, 1300.

Ontario, Manitoulin Island: Williams, 1301. southwestern: Stauffer, 1123; Williams, 1303, 1304.

Quebec, Anticosti Island: Twenhofel, 1190. southern: Harvie, 515.

Tennessee, Perry County: Wade, 1239.

Waynesboro quadrangle: Drake, 366 .

Virginia, Abingdon quadrangle: Stose, 1152.

Yukon, international boundary: Cairnes, 186.

Paleontology.

Alexandrian series: Savage, 1031.

Anticasti Island faunas: Twenhofel, 1190.

Arctic regions: Schuchert, 1055.

Ellesmere Land: Holtedahl, 562.

Maine, Eastport quadrangle: Bastin and Williams, 60.

New York, Gastropoda: O'Connell, 884.

Silver.

General.

Classification of deposits: Lindsley, 755 .

Enrichment: Palmer, 913.

Alaska: Brooks, 124.

British Columbia, Hazelton: Malloch, 803 .

California, Inyo and White Mountains: Knopf, 686.

Darwin district: Knopf, 687.

Central States: Butler and Dunlop, 175. 
Silver-Continued.

Colorado, Silver Lake basin: Prosser, 965.

Eastern States: McCaskey, 776.

Idaho, Dome district: Umpleby, 1209.

Mullan: Calkins and Jones, 192.

Saw tooth quadrangle: Umpleby, 1210.

Mexico, Zimapan (Hidalgo): Lindgren and Whitehead, 754 .

Montana, Dillon quadrangle: Winchell, 1319.

Marysville district: Goodale, $\mathbf{4 7 5}$.

Park County: Gardner, 451.

Saltese: Calkins and Jones, 192.

Nevada, Rochester district: Schrader, 1048.

New Mexico, Organ Mountain district: Welsh, 1274.

Pinos Altos district: Wade, 1241 .

Ontario, Cobalt: Bell, 74.

Oregon, Baker district: Grant and Cady, 487. northeastern: Swartley, 1155.

Sumpter quadrangle: Pardee and Hewett, 918.

United States: McCaskey, 778.

Utah, San Francisco district: Butler, 172.

Washington, northeastern: Bancroft, 31 .

Republic district: Lindgren and Bancroft, 753.

Silver Lake basin, Colorado: Prosser, 965.

\section{Sink holes.}

Missouri, Rolla quadrangle: Lee, 727.

Slate.

Southern States: Grasty and Cline, 490.

United States: Dale et al., 302.

\section{Soapstone.}

Georgia: Hopkins, 568.

United States: Diller, 354.

Soils.

Indiana: Barrett, 52 .

Kentucky: Jones, 632.

Mississippi: Logan, 760.

-United States: Whitney et al., 1291.

Solar hypothesis of climatic changes: Huntington, 599.

South Carolina.

Economic.

Phosphate: Rogers, 1013.

Dynamic and structural.

Charleston, seismic activity: Taber, 1156.

Stratigraphic.

Charleston, boring: Stephenson, 1128.

Palcontology.

Charleston, boring: Stephenson, 1128

Cretaceous, Upper, floras: Berry, 80.

Neocene Mollusca: Olsson, 889.

Underground water.

Charleston wells: Palmer, 912.

\section{South Dakota.}

General.

Report of State geologist 1913-14: Perisho, 930. Economic.

Harney Peak region: Ziegler, 1355.

Dynamic and structural.

Granite intrusion, Black Hills: Paige, 906.

Physiographic.

Wisconsin drift-plain, Sioux Falls region: Carman, 205.
South Dakota-Continued.

Stratigraphic.

Cheyenne River Indian Reservation: Calvert, et al., 193.

Standing Rock Indian Reservation: ' Calvert et al., 193.

Mineralogy.

Black Hills: Zeigler, 1353, 1354, 1356.

Standing Rock Indian Reservation, North and South Dakota: Calvert et al., 193.

Statenliths: Crosby, 287.

Stegosaurus: Gilmore, 460 .

Step faulting.

New Jersey, Raritan quadrangle: Bayley et al., 66.

Stephanosaurus: Lambe, 708.

Stone. See also Building stone.

United States: Burchard, 154 .

Stratigraphic (general). For regional see names of States. See also the different systems.

General: Keyes, 673.

Cretaceous-Tertiary boundary: Brown, 133; Matthew, 819; Osborn, 895; Stanton, 1122.

Rocky Mountain region: Knowiton, 692 .

Time-table: Schuchert and Barrell, 1057.

Correlation.

Alexandrian . series: Savage, 1031.

$\Lambda$ nticosti Island: Twenhofel, 1190.

Cambrian, Cordillera: Burling, 157.

Cretaceous, Iowa: Keyes, 655 .

Eocene, Wyoming and New Mexico: Granger, 485.

Hawthorn formation: Vaughan and Cooke, 1235 .

Miocene, Atlantic coast: Olsson, 888.

Montana beds: Sternberg, 1132.

Montana group: Stebinger, 1126.

Narragansett Basin: Loughlin and Hechinger, 767.

New York, Long Island, Pleistocene formations: Fuller, 441.

Ordovician, Trenton of Kentucky and Tennessee: Foerste, 426.

Pre-Cambrian, Canada: Coleman, 262; Collins, 270; Leith, 732; Miller, 847; Miller and Knight, 848; Schofield, 1043.

Tertiary, California and Great Basin: Merriam, 832.

Texas, Coastal Plain: Deussen, 336.

Table of formations.

Alaska-Yukon boundary: Cairnes, 187.

Antigua: Brown, 130.

A rizona, Shinumo quadrangle: Noble, 880.

British Columbia, Field area: $\Lambda$ lian, 5 .

Nanaimo area: Clapp, 225.

Tulameen district: Cansell, 197.

Vancouver Island: Clapp, 223.

Cambrian, Cordillera: Burling, 157.

Carboniferous: Keyes, 661 .

Idaho, southeastern: Richards and Mansfield, 995.

Illinois, northwestern: Cox, 278.

Iowa: Keyes, 660, 666. 
Stratigraphic-Continued.

Table of formations-Continued.

Kentucky, central: Fohs, 430.

Georgetown quadrangle: Miller, 843.

Lake Superior region: Keyes, 662.

Manitoba: Kindle, 676 .

Michigan: Cook, 273; Smith, 110s.

Gwinn iron district: Allẹn, 14 .

Little Lake district: Allen and Barrett, 15.

Minnesota: Grout and Soper, 502.

Mississippian: Weller, 1270 .

Missouri, northeastern: Greene, 494.

Montana, Big Sandy field: Bowen, 105.

Cleveland field: Bowen, 104 .

Narraganșett Basin: Loughlin and Fechinger, 767.

Newfoundland, Cambrian and Ordovician: Van Ingen, 1222 .

New York: Miller, 849 .

- Attica-Depew quadrangles: Iuther, 775.

Irie County: Houghton, 577.

Niagara region: Kindle, 680.

Saratoga Springs region: Cushing and Ruedemann, 296.

Syracuse quadrangle: Hopkins, 571.

North America: Schuchert and Barrell, 1057.

North Dakota, Cannonball River lignite field: I.loyd, 75 s.

Nova Scotia, Arisaig-Antigonish district: Williams, 1300 .

Ontario, Manitoulin Island: Williams, 1301.

Onaping sheet: Collins, 268.

Rainy Iake: Lawson, 721.

southwestern: Stauffer, 1123; Williams, 1303.

Ordovician, central Kentucky: Foerste, 426.

Orogenic epochs: Blackwelder, 92.

Pennsylvania, Coatesville quadrangle: Bliss and Jonas, 101.

Pre-Cambrian: Coleman, 262; Collins, 270; Miller and Knight, 848; Schofield, 1043.

Quebec, Bell River region: Wilson, 1314 .

Kewagama I ake area: Wilson, 1313.

Tennessee, Perry County: Wade, 1239

Waynesboro quadrangle: Drake, 366

Texas, Coastal Plain: Deussen, 336.

Wyoming, Big Muddy dome: Barnett, 39 .

Douglas field: Barnett, 41.

Lincoln County: Schultz, 1058.

Moorcroft field: Barnett, 40 .

Shoshone River section: Hewett, 534 .

\section{Stream piracy.}

Missonri, southeastern: Dake, 298.

Virginia, western: Watson et al., 1265.

Stream valleys: Rich, 992 .

Stromatoporoidea.

Cryptophragmus: Raymond, 983.

\section{Strontium.}

Arizona: Phalen, 942.

California: Phalen, 942.

United States: Hill, 540 .

Study and teaching. See Educational.

Subsidence. See also Changes of level.

Mining subsidence: Knox, 694 .

Subterranean water. See Underground water.

Sudbury series: Coleman, 262.
Sulphur.

T'exas, southwestern: Becker, 70 .

United States: Phalen, 944.

Wyoming, Park County: Hewett, 533.

Sulphur Springs deposits: Siebenthal, 1086.

Sumpter quadrangle, Oregon: Pardee and Hewett, 918.

Sun River district, Mont.: Powers and Shimer, 959.

Surveys.

Canada, Summary report, 1912 and 1913: Rrock, 120,121

Florida: Sellards, 1066.

Indiana: Barrett, 52 .

Iowa, State geologist's report: Kay, 640, 641.

Michigan, director's report: Allen, 12.

New Jersey, report 1913: Kümmel, 699.

North Dakota: Leonard, 736.

South Dakota, report of State geologist 1913-14: Perisho, 930.

State surveys: DeWolf, 337.

Tennessee, geologist's report, 1914: Purdue, 967.

United States Geological Survey, Director's report: Smith, 1100.

Tables of geologic formations. See under Stratigraphic.

Talc.

Georgia: Hopkins, 568.

New York: Newlands 874.

Origin: Jacobs, 611; Julien, 635.

United States: Diller, 354 .

Vermont: Jacobs, 611 .

Technique.

Contour projection: Smith, 1111.

Fault:nder: Simons, 1088; Weeks and Huntington, 1267 .

Geologic mapping: Paige, 905.

Graphic methods for solution of geologic problems: Smith, 1111.

Microscope, reflecting: Ray, 976 .

Petrographic reports: Tomlinson, 1177.

Sulphur mounting of specimens: Reeds, 987.

Tellurium.

United States: Hess, 529.

Temblor Basin, California: Anderson and Martin 18.

Tennessee.

General.

Geologist's report, 1914: Purdue, 967.

Economic.

Bauxite: Purdue, 969 .

Copper, Ducktown: Thompson, 1167.

Iron, eastern Tennessee: Burchard, 150

types of deposits, east: Tennessee: Gordon, 479.

Phosphate: Barr, 42; Brown, 139; Maynard, 824.

south central Tennessee: Brown, 138; Hook, 567.

Road materials: Purdue, 970.

Tripoli, Glenn, 466.

Butler: Glenn, 465.

Waynesboro quadrangle: Drake, 366 .

Zinc: Purdue, 972. 
Tennessee-Continued.

Dynamic and structural.

Earthquakes, east Tennessee: Gordon, 477.

Hillside wash: Purdue, 968.

Physiographic.

Plains: Glenn, 467.

Stratigraphic.

Perry County: Wade, 1239.

- Waynesboro quadrangle: Drake, 366 .

Paleontology.

Trapa, Henry County: Berry, 85.

Mineralogy.

Ducktown minerals: Van Horn, 1219.

T'erraces. See also Beaches; Shore lines.

Climatic theory: Huntington, 598.

Connecticut Valley: Fairchild, 400.

Delaware River: Winchell, 1323.

Fudson-Champlain valley: Fairchild, 400 .

\section{Tertiary.}

Stratigraphy.

Alaska, Bering River field: Fisher and Calvert, 422 .

Yakataga district: Maddren, 798.

Alberta, Sheep River field: Dowling, 362,364.

Antigua: Brown, 130.

British Columbia, Boundary district: LeRoy, 738.

Fraser River valley: Bowen, 106.

Graham Island: Clapp, 226; MacKenzie, 793.

Groundhog coal field: Malloch, 802 .

Lillooet-Chilko Lake: Bateman, 61.

Savona area: Rose, 1016.

Thompson River valley: Drysdale, 369 .

Vancouver Island: Clapp, 223. southern: Clapp, 227.

California, Alleghany district: Ferguson, 417.

Cahuilla Basin: Free, 438.

Coalinga region: Pack and English, 903.

Colorado Desert: Kew, 653.

Eocene: Arnold and Hannibal, 22; Waring, 1254.

Martinez group: Dickerson, 340 .

Fernando group: English, 393.

Ione formation: Dickerson, 346.

Mohave Desert: Pack, 902.

Rock Creek area: Dickerson, 342.

San Francisco district: Lawson, 724.

San Juan district: Anderson and Martin, 18.

Santa Ana Mountains: Dickerson, 341.

Tejon group: Dickerson, 339 .

Temblor district: Anderson and Martin, 18.

Cannonball member of Lance formation: Lloyd, 759.

Colorado, northwestern: Woodruff and Day, - 1333.

Correlation, Pacific region and Great Basin: Merriam, 832.

Costa Rica, 'Talamanca region: MacDonald 788; Miller, 845.

Cretaceous-Eocene contact, Atlantic and Gulf Coastal Plain: Stephenson, 1120.

Cretaceous-Tertiary boundary: Brown, 133; Matthew, 819; Osborn, 895; Stanton, 1122.

Rocky Mountain region: Knowlton, 692.

Eocene: Matthew, 820.
Tertiary-Continued.

Stratigraphy-Continued.

Eocene formations, Rocky Mountains, petrographic characters: Johannsen, 615.

Florida, Alachua clays: Sellards, 1069.

Georgia: Berry, 80.

Idaho, southeastern: Richards and Mansfield, 995.

Iowa: Keyes, 656 .

Miocene correlation, Atlantic coast: Olsson, 888.

Montana, Big Sandy field: Jowen, 105.

Dillon, quadrangle: Winchell, 1319.

Pine Ridge field: Rogers, 1012.

Sheridan County: Bauer, 64.

Nevada, west central: Buwalda, 183.

New Mexico, Eocene: Granger, 485.

San Juan Basin, Paleocene deposits: Sinclair and Granger, 1093.

North Dakota, Cannonball River lignite field: Lloyd, 758 .

south central: Leonard, 737.

Standing Rock Indian Reservation: Calvert et al., 193.

Oklahoma, Grandfield district: Munn, 869 .

Oregon, Baker district: Grant and Cady, 487.

Eden Ridge field: Lesher, 739.

Eocene: Arnold and Hannibal, 22.

John Day region: Collier, 266.

northwestern: Washburne, 1257.

southwestern: Diller, 352; Winchell, 1320.

Sumpter quadrangle: Pardee and Hewett, 918.

South Carolina: Berry, 80; Rogers, 1013.

Charleston: Stephenson, 1128.

South Dakota, Cheyenne River Indian Reservation: Calvert et al., 193.

Standing Rock Indian Reservation: Calvert et al., 193.

Texas, Coastal Plain: Deussen, 336.

Uinta formation: Douglass, 360.

Utah, Canyon Range: Loughlin, 764. northeastern: Woodruff and Day,. 1333.

Virginia, James River valley: Olsson, 889.

Washington, Pierce County: Daniels, 308. western: Jones, 633 .

Wyoming, Big Muddy dome: Barnett, 39. Douglas field: Barnett, 41 .

Eocene: Granger, 485.

Lincoln County: Schultz, 1058.

Shoshone River section: Hewett, 534.

Yukon, White River district: Cairnes, 190.

Paleontology.

Antigua: Brown, 130.

fresh-water mollusks: ]3rown and Pilsbry, 132.

Atlantic Coastal Plain: Olsson, 889.

British Columbia, Queen Charlotte Islands, invertebrates: J3urwash, 166 .

California, Colorado Desert, Echinoidea: Kew, 653.

Eocene horizons: Waring, 1254.

Eocene, Martinez fauna: Dickerson, 340.

Fernando group: English, 393.

Gastropoda: English, 394.

Neocene Mollusca: Martin, 807.

Pleistocene, Aves: Miller, 846.

Rock Creek area: Dickerson, 342. 
Tertlary-Continued.

Paleontology-Continued.

California, San Francisco district: Lawson, 724:

San Juan district: Anderson and Martin, 18.

Tejon group: Dickerson, 339 .

Temblor district: Anderson and Martin, 18.

Colorado, Florissant, Insecta: Cockerell, 256; Wickham, 1292.

Diploceras, Uinta Eocene: Peterson, 935.

Dolichorhinus, Uinta beds: Peterson, 939.

Dolphin, California: Lull, 771.

Eocene faunas: Matthew, $820,821$.

Eocene flora, southeastern North America: Berry, 86.

Georgia flora: Berry, 80.

Heterotitanops, Uinta beds: Peterson, 936.

Martinez fauna, California: Dickerson, 343.

New Mexico, Mollusca: Cockerell, 249.

New York, Long Island: Gratacap, 491

Nevada, Mammalia: Merriam, 833.

Nipadites, Eocene, Mississippi: Berry, 81.

Oregon, northwestern: Washburne, 1257.

Roseburg quadrangle: Dickerson, 347.

Promerycochorus, Nebraska: Peterson, 940.

South Carolina flora: Berry, 80.

Texas, Coastal Plain: Deussen, 336.

Wyoming, Mollusca: Cockerell, 249, 251.

Texada Island, British Columbia: McConnell, 779 .

Texas.

Economic.

Coal: Phillips and Worrell, 950.

Fuels: Phillips and Worrell, 950.

- Iignite: Phillips and Worrell, 950.

Natural gas, north Texas: Nicholson, 875 .

Petroleum, north Texas: Nicholson, 875 .

Sulphur, southwestern Texas: Becker, 70 .

Van Horn quadrangle: Richardson, 999.

Zinc, Culberson County: Udden, 1204.

Dynamic and structurnl.

Gravels, origin: Udden, 1201.

Physiographic.

Van Horn quadrangle: Richardson, 999.

Stratigraphic.

Boring at Spur, Dickens County: Udden, 1202.

Coastal Plain: Duessen, 336.

Red beds: Case, 208 .

Van Horn quadrangle: Richardson, 999.

Paleontology.

A ræoscelis, Seymour: Williston, 1309.

Broiliellus, Permian amphibian: Williston, 1307.

Coastal Plain: Deussen, 336.

Date palm, Tertiary: Berry, 83 .

Edaphosaurus: Case, 206.

Lysorophus, Permian: Huene, 588.

Reptilia, Permian: Williston, 1309.

Petrology.

Oolitic and pisolitic barite, Saratoga oil field: Moore, 862 .

\section{Mineralogy.}

Meteorites, Davis Mountains, Jeff Davis County: Farrington, 409.

Underground watcr.

Coastal Plain: Deussen, 336.

\section{Textbooks.}

Abrégé de géologie: Huard, 585.

Crystallography: Walker, 1247.

Determination of minerals and rocks: Hobbs, 548.

Engineering geology: Ries and Watson, 1007.

Geology: Chamberlin, 214.

Mineralogy: Foye, 435.

Physical geography: Hopkins, 570.

Physiography: Tarr and Martin, 1158.

Thresherodiscus: Foerste, 429.

Tillite: Sayles, 1034.

Tilting.

Craigton Lake, tilted shore lines: Hubbard, 586.

Ohio, Ashland and Wayne counties: Hubbard, 587.

Tin.

Alaska, Seward Peninsula: Chapin, 220, 221.

South Dakota, Harney Peak region: Ziegler, 1355 .

United States: Hess, 529.

Titanium. See also Rutile.

United States: Hess, 529.

Titanotheres, phylogeny: Osborn, 896 .

Tonopah district, Nevada: Balliet, 30 .

Tortugas atoll: Vaughan, 1231.

Transportation of débris by running water: Gilbert, 458.

Trapa: Berry, 85.

Triassic.

Stratigraphy.

Arizona, Little Colorado Valley: Gregory, 497.

British Columbia, Graham Island: Clapp, 226. Prince Rupert-Aldermere: McConnell, 781.

Savona area: Rose, 1016

Texada Island: McConnell, 779.

Tulameen district: Camsell, 197.

Vancouver Island, Duncan area: Clapp and Cooke, 230.

southern: Olapp, 227.

California, Bully Fill district: Boyle, 113.

Inyo and White Mountains: Knopf, 686.

Colorado, southwestern: Cross and Larsen, 290.

Idaho, southeastern: Richards and Mansfield, 995.

New Jersey, Lockatong formation: Hawkins, 520.

Raritan quadrangle: Bayley ct al., 66 .

New Mexico, red beds: Case, 208.

Nevada, Rochester district: Schrader, 1048.

North Carolina, Dan River field: Stone, 1146.

Oregon, Baker district: Grant and Cady, 4S7.

Pennsylvania, Lockatong formation: Hawkins, 520 .

Texas, red beds: Case, 208 .

Wyoming, Douglas field: Barnett, 41.

Lincoln County: Schultz, 1058.

Paleontology.

California, cestraciont shark: Bryant, 145.

North America, marine invertebrates: Smith, 1102.

Reptilia: Huene, 592.

- Unios, Massachusetts: Troxell, 1183. 
Trilobites.

Dikelocephalinæ, Cambrian: Walcott, 1244.

Isotelus gigas, ontogeny: Raymond, 979.

Paradoxides, ontogeny: Raymond, 978.

\section{Tripoli.}

Missouri, Senaca district: Plumb, 957.

Oklahoma: Plumb, 957.

Tennessee, Butler: Glenn, 465; Glenn, 466.

Waynesboro quadrangle: Drake, 366.

Tufa.

Illinois, Danville: Decker, 332.

Tufa deposits, origin: Jones, 628.

Tungsten.

Gencral: Steinhart, 1127.

South Daknta, Harney Peak region: Ziegler, 1355.

United States: Hess, 529 .

Washington, northeastern: Bancroft, 31.

Turtles. Sce Reptilia.

Uinta formation: Douglass, 360.

Unconformities.

General: Chamberlin, 209.

Bedford-Berea: Burroughs, 160 .

Cretaccous-Eocene contact, $\Lambda$ tlantic and Gulf Costal Plain: Stephenson, 1130.

Cretaceous-Tertiary boundary: Matthew, 819 .

Huronian, Michigan: Allen and Barrett, 15.

Michigan, Little Lake district: Allen and Barrett, 15.

Moencopic-Shinarump: Gregory, 497.

Narragansett Basin: Loughlin and Hechinger, 767.

Ohio, Mississippian: Lamb, 705.

Pre-Cambrian: Sederholm, 1063.

Sub-Cambrian: Leith, 731 .

Sub-Jurassic, Colorado: Cross and Larsen, 291.

Onderground water (general). See also Geysers; Mineral waters; Springs; Thermal waters. For regional see names of States.

Great Plains: Meinzer, 828.

Ground-water table, lowering of: Cook, 274.

Oil-field waters, chlorides in: Washburne, 1258.

Water analyses: Clarke, 239.

Ungulata. See Mammalia.

Upper Silurian. See Silurian.

Uranium.

Carnotites, origin: Hess, 528 .

United States: Hess, 529 .

\section{Utah.}

Economic.

Bituminous shale: Woodruff and Day, 1334.

Book cliffs coal fields: Lewis, 748.

Canyon Range: Loughlin, 764 .

Carnotite deposits, origin: Hess, 528

Carnotite ores: Howard, $\mathbf{5 8 1}$.

Coal, Thompson, Grand County: Clark, 23.5.

Wales, Sanpete County: Clark, 236.

Oil and gas, Green River field, Grand County: Lupton, 773.

Oil shale, northeastern Utah: Woodruff and Day, 1333.

Park City district: Van Horn, 1220.

Phosphate, northern Utah: Peterson, 941.
Utah-Continued.

Economic-Continued.

Radium: Parsons, 922.

San Francisco district, Utah: Butler, 172.

Zinc ores, Tintic district: Loughlin, 765.

Stratigraphic.

Cambrian: Burling, 157.

Canyon Range: Loughlin, 764.

Coal, Thompson, Grand County: Clark, 235.

Green River area: Lupton, 773.

San Francisco district, Utah: Butler, 172.

Uinta formation: Douglass, 360 .

Paleontology.

Titanothere, Dolichorhinus: Peterson, $\mathbf{9 3 9}$.

Uinta Eocene: Peterson, 935, 936.

Mineralogy.

Metahewettite: Hillebrand et al., 541.

Park City district: Van Horn, 1220, 1221.

Pintadoite: Hess and Schaller, 531.

Uvanite: Hess and Schaller, 531.

Valleys.

Anticlinal valleys: Purdue, 971 .

Stream valleys: Rich, 992 .

Vanadium.

United States: Hess, 529.

Van Forn folio (194): Richardson, 999.

Van Horn quadrangle, Texas: 'Richardson, 999.

Vermes. See also Annelida.

Vermont.

Economic.

Marble: Perkins, 932.

eastern Vermont: Dale, 301.

western Vermont: Dale, $\mathbf{3 0 0 .}$

Mineral resources: Perkins, 933.

Talc: Jacobs, 611.

Stratigraphic.

Bennington: Gordon, 476

Greensboro: Richardson and 'Turner, 996.

Hardwick: Richardson et al., 997.

Unconformity, pre-Cambrian: Keith, 648 .

Woodbury: Richardson et al., 997:

Vertebrata (general). Sec also Amphibia, Aves, Mammalia, Pisces, and Reptilia.

Canada: Lambe, 712, 713

Evolution, time ratios: Matthew, 817.

Judith River and Cow Island beds: Sternberg, 1132.

Kansas, Cretaceous: Sternberg, 1131.

Paleocene: Matthew, 819 .

Wyoming, Miccene: Sternberg, 1131.

\section{Virginia.}

General.

Report State geologist 1912-13: Watson, 1260.

Economic.

Coal, Pound quadrangle: Butts, 179, 180 .

Powell Mountain, Scott County: CampbelI, 194

Phosphate, southwestern Virginia: Stose, 1152.

Rutile: Waston, 1261.

Physiographic.

Stream piracy, western Virginia: Watson et al.; 1265. 
Virginia-Continued.

Stratigraphic.

Miocene, James River valley: Olsson, 889.

Ordovician, southwest Virginia: Powell, 958.

Pound quadrangle: Butts, 179, 180.

Paleontology.

Neocene Mollusca: Olsson, 889.

\section{Volcanic ash.}

General: Buttram, 177.

Oklahoma: Buttram, 177.

Volcanic rocks. See Igneous and volcanic rocks.

\section{Volcanism.}

General: Buttram, 177; Iddings, 603.

Magmatic gases: Meunier, 840.

Volcanic phenomena, diagrammatic representation: Perret, 934.

\section{Volcanoes.}

General: Buttram, 177.

California, Lassen Peak, eruptions: Boyce, 112; Diller, 349-351; Holway, 565; Storms, 1151; Wright, 1347.

Costa Rica, Miravalles: Peralta, 929; Tristán, 1179.

Hawaii, Kilauea: Day, 325; Hawaiian Volcano Observatory, 518, 519; Jaggar, 612.

Nicaragua, Masaya: Sapper, 1029.

Volcanoes (extinct).

British Columbia, Coast Range: Burwash, 167. Garibaldi volcanic area: Burwash, 169.

Mount Royal, Quebec: Buchan, 148.

\section{Washington.}

Economic.

Cement materials: Shedd, 1080.

Coal, Pierce County: Daniels, 308.

Glacier coal field, Whatcom County: Woodruff, 1332.

Issaquah coal field: Evans, 398.

Mineral resources: Landes, 714 .

Northeastern Washington: Bancroft, 31 . .

Olympic Peninsula, western part: Lupton, 774.

Republic district: Lindgren and Bancroft, 753.

Dynamic and structural.

Glaciers, Mount Rainier: Matthes, 813 .

Physiographic.

Mount Rainier, glaciers: Matthes, 812.

Stratigraphic.

Glacier coal field, Whatcom County: Woodruff, 1332.

Miocene, lower: Weaver, 1266.

Northeastern Washington: Bancroft, 31.

Olympic Peninsula, western part: Lupton, 774.

Pierce County: Daniels, 308.

Western Washington, coal-bearing Eocene: Jones, 633 .

Water, underground. See Underground water.

Waverly formation, Kentucky: Morse and Foerste, 867.

Waynesboro quadrangle, Tennessee: Drake, 366.

Well records. See Borings.

Wells, deep: White, 1286.

West Indies (general). See also names of islands. General.

Barrier reefs, platforms: Vaughan, 1234.

Physiographic.

Coral reef areas: Vaughan, 1232.

\section{West Virginia.}

Economic.

Kanawha County: Krebs and Teets, 697.

Map of coal, oil, gas, iron, and limestone areas: W. Va. G. S., 1276.

Pittsburgh coal bed: Burroughs, 163.

Preston County: Hennen and Reger, 527.

Physiographic.

Kanawha County: Krebs and Teets, 697.

Preston County: Hennen and Reger, 527.

Stratigraphic.

Boring, Kanawha County: White, 1287.

-Kanawha County: Krebs and Teets, 697.

Kanawha series: Hennen, 526; White, 1286.

Preston County: Hennen and Reger, 527.

Palcontology.

Kanawha County: Price, 962.

Preston County: Price, 963.

White River district, Yukon: Cairnes, 190.

Willow Creek district, Alaska: Capps, 202.

Wind work.

General: Udden, 1203.

\section{Wisconsin.}

Economic.

Iron, "Clinton" ore: Thwaites, 1169.

Physiographic.

Lakes: Birge and Juday, 91.

Physical geography: Martin, 809.

Paleontology.

Dikelocophalinæ, Cambrian: Walcott, 1244.

Mineralogy.

Meteorites, Kilbourn: Farrington, 409.

Wissahickon mica gneiss, Coatesville quadrangle, Pa.: Bliss and Jonas, 101.

\section{Wyoming.}

Economic.

Douglas oil and gas field, Converse County: Barnett, 41.

Gold, Atlantic City district, Fremont County: Trumbull, 1185, 1187.

Gold placers, Wind and Bighorn rivers: Schrader, 1047.

Kirwin: Hewett, 533.

Lincoln County: Schultz, 1058.

Moorcroft oil field, Crook County: Barnett, 40.

Salt Creek oil field, Natrona County: Trumbull, 1186.

Shoshone River section: Hewett, 534.

Sulphur, Park County: Hewett, 533 .

Physiographic.

Central western Wyoming, post-Cretaceous history: Blackwelder, 93.

Stratigraphic.

Atlantic City district, Fremont County: Trumbull, 1185.

Big Muddy dome, Converse and Natrona counties: Barnett, 39 .

Douglas oil and gas field, Converse County: Barnett, 41.

Eocene faunal horizons: Granger, 485.

Lincoln County: Schultz, 1058.

Salt Creek oil field, Natrona County: Trumbull, 1186.

Shoshone River section: Hewett, 534 . 
Wyoming-Continued.

Paleontology.

Dinosauria: Gilmore, 460.

Fossil forests, Yellowstone National Park: Knowlton, 692.

Miocene vertebrates: Sternberg, 1131.

Tertiary Mollusca: Cockerell, 249, 251.

Tithymalus,.Clarks Fork Basin: Cockerell, 255.

Petrology.

Eocene formations, Rocky Mountains, petrographic characters: Johannsen, 615 .

\section{Yellowstone National Park.}

Fossil forests: Knowlton, 692.

Yosemite Valley: French, 440; Matthes, 811.

\section{Yukon.}

General: Tyrrell, 1195.

White River district: Cairnes, 190.

\section{Economic.}

General: Tyrrell, 1195.

Coal: Payne, 925; Tyrrell, 1195.

Klondike district: Bell, 75; Cadell, 184; MacLean, 797.

White River district: Caimes, 190.
Yukon-Continued.

Stratigraphic.

Alaska-Yukon boundary: Cairnes, 186, 187, 189.

Klondike district: Bell, 75 .

Paleontology.

Cambrian: Burling, 159.

Mineralogy.

Yukonite: Tyrrell and Graham, 1198.

Zaphrentis, revision: O'Connell, 883.

Zinc.

British Columbia, Field area: Allan, 5 .

California, Inyo and White Mountains: Knopf, 686.

Central States: Butler and Dunlop, 175.

Eastern States: McCaskey, 776.

Idaho, Sawtooth quadrangle: Umpleby, 1210.

Illinois, northwestern: Cox, 278.

Nevada, Yellow Pine district: Hill, 538 .

Oklahoma, Arbuckle Mountains: Becker, 71.

Tennessee: Purdue, 972.

Texas, Culberson County: Udden, 1204.

United States: Siebenthal, 1087.

Utah, San Francisco district: Butler, 172.

Tintic district: Loughlin, 765.

Washington, northeastern: Bancroft, 31. 


\section{LISTS.}

\section{CHEMICAI ANALYSES. 1}

[The numbers refer to entries in the bibliography.]

Actinolite, 432, 568 .

Adamellose, 851.

Alaskite porphyry, 113.

Alunite, 1048.

Amphibolite, 223.

Analcite, 794.

Andesite, 1319, 1320.

Andradite, 223, 718.

Anorthosite, 892 .

Anthophyllite, 568 .

Anthracite, 23.

Argillite, 1320.

Auganite, 1319, 1320.

Augen gneiss, 420 .

Augite syenite, 66, 197, 851 .

Auvergnose, 223, 418, 568 .

Average analyses, 826 .

Axinite, 1281.

Barite, 151.

Barytes, 430.

Basalt, 66, 164, 288, 418, 721 .

Beemerose, 418.

Beerbachose, 223.

Beraunite, 1281.

Biotite granite, 1142.

Biotite granite gneiss, 223.

Biotite-quartz monzonite gneiss, 1261 :

Biotite vulsinite, 420 .

Blairmorite, 794.

Bornite, 696 .

Bournonite, 1220.

Brine, 443.

Camptonite, 420.

Camptonose, 418.

Carnotite, 1278.

Cebollite, 719 .

Chlorite, 568 .

Chromic iron ore, 353.

Chrysocolla, 1211.

Chrysotile, 568 .

Clay, 26, 147, 282, 382, 502, 737, 874, 1080.

Coal, 103, 104, 105, 147, 195, 225, 226, 235, 236, 233, 308, $363,397,422,494,551,552,555,556,600,682,739,748$, $793,802,808,1017,1032,1268,1298,1320,1331$.

Corsase, 568 .

Crinoid skeletons, 241.

Crocidolite, 568.

Custerite, 1214.

Dacite, 172, 1313.

Dacite porphyry, 1320.

Diabase, 66, 101, 367, 850, 1261 . .
Diallage, 367.

Diopside, 223.

Diopside rock, 1208, 1209.

Diorite, $420,1313,1319$.

Dolomite, 101, 684, 1313.

Dolorite, 420 .

Dunite, 568 .

Dunose, 197, 568.

Empressite, 114, 1036.

Enstatitite, 568.

Epidosite, 420 .

Epidote, 223.

Epidote gneiss, 568.

Essexite, 418, 892.

Essexite porphyry, 892 .

Essexose, 418.

Feldspar porphyry, 164.

Gabbro, 420, 568, 850, 1042, 1261, 1320.

Gabbro-diorite gneiss, 223.

Gabbro-nelsonite, 1261.

Garnet rock, 1208, 1209.

Gas, 1075.

Gneiss, 66, 101, 296, 420, 721.

Gordunose, 568.

Granite, 197, 296, 618, 721, 851, 1042, 1142, 1256, 1320.

Granite porphyry, 1208, 1209.

Granodiorite, 197, 223.

Granophyr, 28.

Greenstone, 164.

Greenstone schist, 721.

Harzburgite, 568 .

Harzose, 851.

Heronite, 794.

Hessose, 197, 568.

Hewettite, 541.

Hodgkinsonite, 911.

Hornblende, 223, 432.

Hornblende gabbro, 28, 568, 721 .

Hornblende gneiss, 568 .

Hornblende schist, 721.

Hornblende-augite vogesite, 288.

Hornblendite, 223.

Hydronephelite, 5 .

Hypersthene gabbro, 28, 1042.

Ijolite, 5 .

Iron ore, $20,150,268,749,750,751$.

Jamesonite, 1220.

Kaersutite, 432.

Kyanite schist, 264.

Lamprophyre, 164 .

Lassenose, 197.

1 The analyses in Daly, 304, have not been included in this list. 
Laterite, 1320.

Lava, 172.

Leucite trachyte, 418.

Lignite, 64, 266, 737, 758 .

Limburgite, 288 .

Limburgose, 288, 418.

Limestone, 66, 172, 223, 293, 300, 352, 425, 436, 523, 527, $721,724,738,999,1080,1081,1208,1209,1299,1320$. Limonite orc, 66 .

Magnetite pyroxenite, 1320 .

Marble, 300, 1299.

Maricose, 568 .

Marl, 1013.

Melilite, 718 .

Metagabbro, 101.

Metahewettite, 541.

Miaskose, 418.

Mica gneiss, 101.

Mica schist, 101, 721 .

Mica syenite gneiss, 721.

Micropegmatite, 1042.

Minette, 288, 1313.

Mississippi silt, 240.

Monchiquose, 288.

Monzonite, 172.

Monzonite porphyry, 172.

Monzonose, 738.

Muthmannite, 1036.

Nelsonite, 1261.

Nephelite basanite, 288, 418.

Nephelite-sodalite syenite, 892 .

Nephelite syenite, $5,418,892$.

Norite, 66.

Oil shale, 1349.

Olivine-bearing augite vogesite, 288.

Olivine monzonite, 288.

Olivine-plagioclase basalt, 288.

Olivine trachydolerite, 1319.

Olivine websterite, 568 .

Oolite, 141.

Oolitic sand, 141.

Ophicalcite, 66 .

Ouroso-kentallenose, 288.

Pargasite, 432.

Pascoite, 541.

Peat, 1067.

Peridotite, 197, 1319.

Petroleum, 41, 534, 998.

Phosphate, 426.

Phosphate rock, 1013.

Phyllite, 420.

Picrolite, 568 .

Pintadoite, 531.

Pisanite, 1219.

Psilomelane, 724.

Pulaskose, 851, 892.

Pyroxene rock, 1208, 1209.
Pyroxenite, 197, 367, 1319.

Quartz diorite, 28, 1042.

Quartz diorite gneiss, 223.

Quartz monzonite, 172, 1142, 1319.

Quartzite, 101; 1042.

Ranite, 5.

Rhyodacite, 1320 .

Rhyolite, 724, 1048, 1319.

Rossweinose, 568.

Rougemontite, 892 .

Rouvillite, 892 .

Rutile, 1261.

Salemose, 892.

Salines, 449 .

Salt, 443.

Schist, 420,495 .

Schorlomite, 5 .

Searlesite, 717 .

Sericite, 5 .

Serpentine, 568,1320

Shale, 502, 724, 874, 1080, 1081.

Shonkinite, 892.

Shoshonose, 738.

Silicate rock, 1209.

Silt from Mississippi River, 240.

Slate, 5,367 .

Soapstone, 568 .

Sodalite, 5 .

Soretite, 432

Spessartite, 1320.

Sudburite, 264.

Sulphohalite, 450.

Syenite, 5, 721, 851, 1261.

Talc, 568,611 .

Tawite, 892.

Temiskamite, 1248 .

Theralite, 892.

Tinguaite, 794, 892.

Tonalite, 1320.

Toscanose, 851.

Trachyte obsidian, 418.

Tremolite, 432, 568 .

Tripoli, 465.

Tuff, 724.

Umptekose, 418.

Urtite, 892.

Ussingite, 102.

Uvanite, 531 .

Volcanic dust, 177.

Vulsinose, 418 .

Water, 228, 239, 283, 682, 715, $829,999,1081,1228$,

1258,1320 .

Wilkeite, 379 .

Wolframite, 1281 .

Wollastonite rock, 1208, 1209.

Yamaskite, 892.

Yukonite, 1198.

\section{MINERALS DESCRIBED. 1}

Actinolite, 432, 568 .

Arsenopyrite, 1219

Alamosite, 838 .

Anatase, 718.

Andradite, 718.

Anhydrite, 449

Anthophyllite, 568 .

Aurichalcite, 765 .

Axinite, 1281.

Azurite, 838 .

Babingtonite, 414, 415.

Beraunite, 1281 .

Bloedite, 446 .

1 The mincrals described in Ėakle, 377, and Ziegler, 1353, have not been included in this list. 
Borax, 449.

Bornite, 695 .

Calamine, 765, 1220.

Calcite, 765.

Cebollite, 719 .

Chrysocolla, 1211.

Chrysotile, 568 .

Colemanite, 447.

Crocidolite, 568 .

Custerite, 1214.

Empressite, 114, 1036.

Ferberite, 530 .

Fremontite, 1036.

Glauberite, 449.

. Gypsum, 449.

Halite, 449.

Hanksite, 449.

Hodgkinsonite, 909, 911

Hornblende, 432.

Hydrozincite, 765 .

Inyoite, 1036.

Jamesonite, 1220.

Koechlinite, 1036.

Malachite, 765.

Manganosite, 433.

Melilite, 718.

Metahewettite, 541 .

Meyerhofferite, 1036.

Mirabilite, 449.

Muthmannite, 1036.
Bournonite, 1220.

Chalcophanite, 433.

Gaylussite, 449.

Hewettite, 541 .

Lucinite, 1036.

\author{
Natron, 449. \\ Nor thupite, 449. \\ Okenite, 379. \\ Pandermite, 447. \\ Pascoite, 541. \\ Perofskite, 718. \\ Picrolite, 568. \\ Pintadoite, 531. \\ Pirssonite, 449. \\ Pisanite, 1219. \\ Pseudomalachite, 1356. \\ Romeine, 1036. \\ Roscoelite, 1540. \\ Schneebergite, 1036. \\ Searlesite, 449, 717. \\ Serpentine, 568 . \\ Sillimannite, 1356. \\ Smithsonite, 765 . \\ Spangolite, 433. \\ Staurolite, 1219. \\ Sulphohalite, 449, 450. \\ Symplesite, 1198. \\ Temiskamite, 1248. \\ Thenardite, 449. \\ Tremolite, 432, 568 . \\ Trona, 449. \\ Tychite, 449. \\ Ussingite, 102. \\ Uvanite, 531. \\ Velardenite, 1036. \\ Wilkeite, 379. \\ Wolframite, 530, 1281. \\ Wurzite, 974. \\ Yukonite, 1198.
}

\section{ROCKS DESCRIBED.}

Actinolite schist, 420 .

Alaskite porphyry, 113.

Alkaliaplite, 1319.

Amphibole-pyroxene gneiss, 568 .

Amphibolite, 223, 568, 1313.

Andesite, 60, 1319, 1320.

Andose, 296.

Aplite, 1319, 1320.

Aplite porphyry, 1319.

Argillite, 1320.

Auganite, 1319, 1320.

Augen gneiss, 420.

Augite minette, 288.

Augite porphyrite, 738 .

Augite syenite, 197.

Augitite, 1320.

Auvergnose, 568.

Basalt, 492, 1313, 1319, 1320.

Basalt breccia, 492.

Beerbachose, 223.

Biotite granite gneiss, 223.

Biotite-quartz monzonite gneiss, 1261.

Blairmorite, 794 .

Borolanite, 5 .

Bostonite, 1319.

Camptonite, 892 .

Corsase, 568 .

Covite, 5.

Cumberlandite, 1256.

Dacite, 1313, 1319, 1320 .
Diabase, 60, 101, 164, 288, 367, 492, 850, 880, 1261, $1313,1315$.

Diorite, 420, 568, 1313, 1319, 1320.

Diorite porphyrite, 223.

Ditroite, 5 .

Dolomite, 101, 1313.

Dunite, 568 .

Dunose, 197, 568 .

Enstatitite; 568 .

Epidosite, 420.

Epidote, 492.

Epidote gneiss, 568.

Essexite, 892.

Essexite porphyry, 892.

Feldspar porphyry, 164 .

Felsite, 1256.

Foyaite, 5 .

Gabbro, 223, 367, 568, 850, 1042, 1256, 1261, 1313, 1320.

Gabbro-diorite gneiss, 223.

Gabbro-diorite-porphyrite, 223.

Gabbro-nelsonite, 1261.

Garnet gneiss, 1315.

Gneiss, 101, 296, 721, 850, 1261, 1313.

Gordunose, 568 .

Granite, 60, 164, 197, 296, 367, 420, 721, 850, 1039, 1042, 1142, 1256, 1313, 1315, 1319, 1320.

Granite gneiss, 1315.

Granite porphyry, 850.

Granitoid gneiss, 114.

Granodiorite, 197, 223, 738, 918, 1188, 1319. 
Granodiorite gneiss, 420.

Granophyr, 28.

Greenstone, 721.

Harzburgite, 568 .

Hedrumite, 5 .

Hessose, 197, 568.

Hornblende-augite vogesite, 288.

Hornblende gabbro, 28, 568 .

Hornblende gneiss, 568 .

Hornblende porphyrite, 420, 738 .

Hornblende schist, 420, 568 .

Hornblendite, 223, 420 .

Hypersthene gabbro, 28, 1042.

Hypersthenite, 568 .

Ijolite, 5 .

Kersantite, 1320.

Lamprophyre, 164, 197, 721, 1313, 1315.

Lassenose, 197, 296.

Laterite, 1320 .

Latite, 794, 1319.

Laurvikite, 5 .

Limburgose, 288.

Malchite, 1320 .

Maricose, 568

Meta-andesite, 223.

Meta-augite andesite, 223.

Metabasalt, 223.

Mettagabbro, 101.

Metaolivine basalt, 223.

Metaperidotite, 568 .

Metapyroxenite, 568 .

Miascite, 5 .

Mica gneiss, 101.

Mica schist, 101, 420, 721 .

Mica syenite gneiss, 721 .

Micropegmatite, 114, 1042.

Minette, 288, 1313, 1319.

Monchiquose, 288.

Monzonite, 1142.

Monzonite porphyry, 738.

Monzonose, 738 .

Nelsonite, 1261.

Nephelite-sodalite syenite, 892.

Nephelite syenite, 5,892 .

Norite, 114.

Norite-diorite, 1188.

Olivine basalt, 197, 738.

Olivine gabbro, 568 .

Olivine trachydolerite, 1319.
Olivine websterite, 568.

Olivine-bearing augite vogesite, 288.

Olivine-plagioclase basalt, 288.

Ourose-kentallenose, 288.

Pegmatite, 101, 1315, 1319, 1320.

Periodotite, 197, 367, 568, 1319, 1320.

Phyllite, 420.

Plagiaplite, 1319

Porphyrite, 367 .

Porphyry, 1256.

Pulaskite porphyry, 738.

Pyroxene syenite, 850 .

Pyroxenite, 197, 367, 568, 1315, 1319, 1320.

Quartz diabase, 492 .

Quartz diorite, 28, 880, 1042, 1256.

Quartz diorite gneiss, 223.

Quartz-feldspar porphyrite, 223.

Quartz latite, 1319.

Quartz monzonite, 1142, 1319.

Quartz monzonite aplite, 1319.

Quartz monzonite porphyry, 1319.

Quartz porphyrite, 738 .

Quartz syenite, 850 .

Quartzite, 101, 420, 1320 .

Quartzite-diorite, 1042.

Rhyodacite, 1320

Rhyolite, 60, 1319, 1320.

Rossweinose, 568 .

Rougemontite, 892 .

Rouvillite, 892 .

Salemose, 892

Schist, 420.

Serpentine, 101, 367, 420, 1320.

Shoshonose, 738.

Spessartite, 1320.

Sudburite, 114, 264.

Syenite, $5,164,296,721$.

Syenite porphyry, 1313.

Tawite, 892.

Theralite, 5 .

Tinguaite, 288, 794, 892.

Tönsbergite, 5 .

Tonalite, 1319, 1320 .

Tonalite aplite, 1319.

Trachy te, 794, 1319.

Tremolite schist, 420

Troctolite, 568 .

Urtite, 5 .

Yamaskite, 892

\section{GEOLOGIC FORMATIONS DESCRIBED.}

Abitibigroup, pre-Cambrian, Quebec: Wilson,1313, | Aftonian interglacial deposits, Ploistocene, Iowa: 1314.

Abitibi volcanics, pre-Cambrian, Quebec: Wilson 1313.

Abrams formation, pre-Cambrian?, Oregon: Winchell, 1320.

Acadian division, Cambrian, New Brunswick: Matthew, 816.

Adams Lake forration, pre-Beltian, British Columbia: Daly, 306.

Adaville formation, Cretaceous, Wyoming: Schultz, 1058.

Admiralty till, Pleistocene, British Columbia: Clapp, 223, 225, 227.

Tilton, 1171

Aftonian stage, Pleistocene, Iowa: Hay, 522.

Alachua clays, Tertiary, Florida: Sellards, 1056.

Alameda formation, Pleistocene, California: Lawson, 724 .

Albert Canyon division, Beltian, British Columbia: Daly, 306.

Albright limestone, Carboniferous, West Virginia: Hennen and Reger, 527.

Aldridge formation, pre-Cambrian, British Columbia: Schofield, 1039, 1040, 1043.

Alexandrian series: Keyes, 661.

Alexandrian series, Silurian, Missouri: Keys, 659. $97921^{\circ}-$ Bull. $617-15-10$ 
Algoman, pro-Cambrian, Lake Superior region: Leith, 732.

Algoman, pre-Cambrian, Ontario: Lawson, 721; Miller and Knight, 848.

Algomic period, pre-Cambrian, Lake Superior region: Keyes, 662 .

Allegheny series, Carboniferous, West Virginia: Hennen and Reger, 527; Krebs and Teets, 697.

Allison (Belly River) formation, Cretaceous, Alberta: MacKenzie, 792, 794.

Almagre beds, Tertiary, Wyoming: Granger, 485.

Almy formation, Eocene, Wyoming: Schultz, 1058.

Alta shale, Cambrian, Utah: Burling, 157.

Altamont moraine, Pleistocene, North Dakota: Leonard, 737.

Alum Bluff formation, Tertiary, Florida: Vaughan and Cooke, 1235.

Ames formation, Carboniferous, West Virginia: Hennen and Reger, 527.

Amherstburg dolomite, Silurian, Michigan: Sherzer, 1081.

Amherstburg dolomite, Silurian, Ontario: Stauffer, 1123.

Amisk series, pre-Cambrian, Saskatchewan: Bruce, 144.

Amsterdam limestone, Ordovician, New York: Cushing and Ruedemann, 296.

Anamosa terrane, Silurian, Iowa: Keyes, 661.

Anderdon limestone, Silurian, Michigan: Sherzer, 1081.

Anderdon limestone, Silurian, Ontario: Stauffer 1123.

Anderson Bay formation, Triassic, British Columbia: McConnell, 782.

Andover granite, Pennsylvanian, Massachusetts, Clapp, 222.

Angola shale, Devonian, New York: Houghton, 577.

Anianic period, pre-Cambrian, Lake Superior region: Keyes, 662 .

Animikean, pre-Cambrian, Ontario: Miller and Knight, 848 .

Animikian series: Keyes, 661 .

Animikian series, pre-Cambrian, Lake Superior r' $\theta$ gion: Keyes, 662 .

Animikie, pre-Cambrian, Canada: Coleman, 262.

Animikie series, pre-Cambrian, Ontario: Miller and Knight, 848 .

Ankareh shale, Triassic, Idaho: Richards and Mansfield, 995.

Ankareh shale, Triassic, Wyoming: Schultz, 1058.

Anticosti series, Silurian, Anticosti Island: Twenhofel, 1190.

Antigua formation, Oligocene, Antigua: Brown, 130.

Antrim formation, Devonian, Michigan: Cook, 273.

Antrim shale, Devonian, Michigan: Sherzer, 1081; Smith, 1108.

Apsey formation, Ordovician, Newfoundland: Van Ingen, 1222.

Arago beds, Eocene, California and Oregon: Arnold and Hannibal, 22

Arago formation, Eocene, Oregon: Lesher, 739.

Ardness formation, Carboniferous, Nova Scotia: Williams, 1300.

Arisaigseries, Silurian, Nova Scotia: Williams, 1300. Arkansan series: Keyes, 661.
Arnheim limestone, Ordovician, Tennessee: Drake, 366 .

Arnoldsburg sandstone, Pennsylvanian, West Virginia: Krebs and Teets, 697.

Ashcroft rhyolite porphyry formation, Tertiary, British Columbia: Drysdale, 369.

Ashton schists, pre-Cambrian, Rhode Island and Massachusetts: Warren and Powers, 1256.

Aspen formation, Cretaceous, Wyoming: Schultz, 1058.

Astoria shale, Oligocene and Miocene, Oregon: Washburne, 1257.

Atchison terrane, Carboniferous, Iowa: Keyes, 661. Atkinson terrane, Ordovician, Iowa: Keyes, 661 .

Athens shale, Ordovician, Virginia: Stose, 1152.

Atoka formation, Pennsylvanian, Arkansas and Oklahoma: Smith, 1097.

Atoka formation, Pennsylvanian, Oklahoma: Snider, 1113.

Aturia zone of Astoria shale, Oregon: Washburne, 1257.

Augur conglomerate lentil, Permian, Oklahoma Munn, 869.

Aubrey group, Carboniferous (Pennsylvanian), Arizonà: Hill, 539; Noble, 880.

Avalonian formation, pre-Cambrian, Newfoundland: Van Ingen, 1222.

Bad Vermilion Lake granite, pre-Cambrian, Ontario: Lawson, 721.

Bakerstown fire clay, Pennsylvanian, West Virginia: Krebs and Teets, 697 .

Bald Mountain limestone, Ordovician, New York: Cushing and Ruedemann, 296.

Bald Peak basalt, Pliocene, California: Lawson, 724.

Baltimore gneiss, pre-Cambrian, Pennsylvania: Bliss and Jonas, 101.

Banff (Lower) limestone, Carboniferous, Alberta Allan, 5 .

Banff (Lower) shale, Carboniferous, Alberta: Allan, 5 .

Banff (Upper) limestone, Carboniferous, Alberta: Allan, 5.

Banff (Upper) shale, Permian, Alberta: Allan, 5 . Bass limestone, Algonkian, Arizona: Noble, 880.

Bass Island series, Silurian, Michigan: Sherzer 1081; Smith, 1108.

Bastion schists, pre-Beltian, British Columbia: Daly, 306.

Baxters Brook formation, Ordovician, Nova Scotia: Williams, 1300.

Bayport limestonø, Mississippian, Michigan: Smith, 1108.

Bayport (Maxville) limestone, Mississippian, Michigan: Cook, 273.

Bays sandstone, Ordovician, Virginia: Stose, 1152. Beach formation; Ordovician, Newfoundland: Van Ingen, 1222.

Bear River formation, British Columbia: McConnell, 780 .

Bear River formation, Cretaceous, Wyoming: Schultz, 1058.

Bearpaw shale, Cretaceous, Montana: Bowen, 103, 104, 105; Stebinger, 1125, 1126.

Bearpaw shale, Upper Cretaceous or Eocene, Montana: Stebinger, 1124 . 
Bearpaw shales, Cretaceous, Alberta: Dowling, 362, 364 .

Beaumont clay, Pleistocene, Texas: Deussen, 336.

Beckwith formation, Cretaceous and Jurassic, Idaho: Richards and Mansfield, 995.

Beckwith formation, Jurassic, Wyoming: Schultz, 1058.

Becsie River formation, Silurian, Anticosti Island: Twenhofel, 1190.

Bedford "augen" gneiss, New York: Fettke, 420.

Bedford formation, Carboniferous, Ohio and Kentucky: Morse and Foerste, 867.

Beechhill Cove formation, Silurian, Nova Scotia: Williams, 1300.

Beech River limestone, Silurian, Tennessee: Drake, 366 .

Beech River member, Silurian, Tennessee: Wade, 1239.

Bee Spring sandstone, Carboniferous, Kentucky: Bryant, 147.

Bell Island series, Ordovician, Newfoundland: Van Ingen, 1222.

Bell shale, Devonian, Michigan: Cook, 273.

Bellevue, Ordovician, Indiana: Cumịngs and Galloway, 295.

Bellingham series, Carboniferous, Rhode Island and Massachusetts: Warren and Powers, 1256.

Belly River beds, Cretaceous, Alberta: Stebinger, 1126.

Belly River beds, Cretaceous, Canada: Brown, 133. Belly River formation, Cretaceous, Alberta: Dowling, 362, 364 .

Belly River formation, Cretaceous, Canada: Stebinger, 1125.

Belt series, Algonkian, Idaho and Montana: Calkins and Jones, 192.

Beltian, pre-Cambrian, British Columbia: Schofield, 1043.

Beltian system: Daly, 306.

Benson conglomerates, Cretaceous, British Columbia: Clapp, 225 .

Benson limestone, Ordovician, Kentucky: Foerste, 427.

Benton formation, Cretaceous, Alberta: MacKenzie, $792,794$.

Benton shale, Cretaceous, Minnesota: Grout and Soper, 502.

Benton shale, Cretaceous, Wyoming: Barnett, $39,41$.

Berea formation, Carboniferous, Ohio and Kentucky: Morse and Foerste, 867.

Berea grit, Mississippian, Michigan: Cook, 273.

Berea sandstone, Carboniferous, Ohio: Burroughs, 147.

Berea sandstone, Mississippian, Michigan: Sherzer, 1081; Smith, 1108

Berkeley group, Pliocene, California: Lawson, 724. Berkshire schist, Ordovician, Vermont: Dale, 300. Bertie limestone, Silurian, New York: Houghton, 577.

Bertie waterline, Silurian, New York: Hopkins, 571.

Bertram terrane, Silurian, Iowa: Keyes, 661.

Bethany terrane, Carboniferous, lowa: Keyes, 661. Bethany Falls limestone, Pennsylvanian, Iowa: Tilton, 1070 .
Beverly syenites, Mississippian or Pennsylvanian, Massachusetts: Clapp, 222.

Bigby formation, Ordovician, Kentucky: Miller, 843.

Binnewater sandstone, New York: Brown, 140.

Birmingham shale, Pennsylvanian, West Virginia: Krebs and Teets, 697.

Bitter Creek formation, British Columbia: McConnell, 780.

Biwabik formation, Algonkian, Minnesota: Grout and Soper, 502.

Black shale, Devonian, Tennessee: Wade, 1239.

Black Creek formation, Cretaceous, South Carolina: Stephenson, 1129.

Black Creek formation, Upper Cretaceous, South Carolina: Berry, 80.

Black Hand formation, Carboniferous, Ohio and Kentucky: Morse and Foerste, 867.

Blackstone series, pre-Cambrian, Rhode Island and Massachusetts: Warren and Powers, 1256.

Bloomsbury formation, Quebec: Hayes, 523 .

Blue Canyon formation, Carboniferous, California: Ferguson, 417.

Bob limestone, Silurian, Tennessee: Drake, 366 .

Bob member, Silurian, Tennessee: Wade, 1239.

Boggy shale, Pennsylvanian, $\Lambda$ rkansas and Oklahoma: Smith, 1097.

Boggy shale, Pennsylvanian, Oklahoma: Snider, 1113.

Bohio conglomerate, Tertiary, Costa Rica: MacDonald, 788 .

Bolivar fire clay, Carbonjferous, West Virginia: Hennen and Reger, 527; Krelos and Teets, 697.

Bomoseen grit, Cambrian, New York: Cushing and Ruedemann, 296.

Bonavista formation, Cambrian, Newfoundland: Van Ingen, 1222

Bonita sandstone, Jurassic ?, California: Lawson, 724.

Bonneterre formation, Cannbrian, Missouri: Lee, 727.

Boone formation, Mississippian, Oklahoma: Snider, 1114.

Boone limestone, Mississippian, Oklahoma: Smith, 1098.

Boss Point formation, Pennsylvanian, Nova Scotia: Bell, 77.

Bosworth formation, Cambrian, British Columbia: Allan, 5,6 .

Boulder granite, Jurassic, British Columbia: Camsell, 197.

Bowling Green limestone, Silurian, Illinois, Missouri: Savage, 1031.

Bowling Green limestone, Silurian, Missouri: Keyes, 659.

Boyle limestone, Devonian, Kentucky: Munn, 869.

Bragdon formation, Carboniferous, California: Ferguson, 416.

Brainard terrane, Ordovician, Iowa: Keyes, 661.

Brannon, Ordovician, Kentucky: Miller, 843.

Brannon limestone, Ordovician, Kentucky: Foerste, 427.

Brassfield formation, Silurian, Ohio and Indiana: Schuchert, 1054.

Brassfield limestone, Silurian, Kentucky: Morse and Foerste, 867. 
Brassfield limestone, Silurian, Tennessee: Drake, 366; Wade, 1239.

Bretonian division, Cambrian, New Brunswick: Matthew, 816.

Brewerville formation, Mississippian, Mississippi Valley: Weller, 1270.

Brewerville sandstone, Mississippian, Illinois: Weller, 1269.

Bridger formation, Tertiary, Colorado and Utah: Woodruff and Day, 1333.

Bright Angel shale, Cambrian, Arizona: Hill, 539; Noble, 880.

Brigus formation, Cambrian, Newfoundland: Van Ingen, 1222.

Briones sandstone, Miocene, California: Lawson, 724.

Broadback series, pre-Cambrian, Quebec: Cooke, 275.

Bromley member, Ordovician, Kentucky: Foerste, 427.

Brooklyn formation, Carboniferous, British Columbia: LeRoy, 738.

Brown Mead formation, Ordovician, Newfoundland: Van Ingen, 1222.

Browns Mountain group, Ordovician, Nova Scotia: Williams, 1300.

Brownsport formation, Silurian, Tennessee: Drake, 366.

Brownsport group, Silurian, Tennessee: Wade, 1239. Brownstown sandstone, Carboniferous, West Virginia: Krebs and Teets, 697.

Bruce series, pre-Cambrian, Ontario: Collins, 270.

Brunswick shale, Triassic, New Jersey: Bayley $c t$ $a l ., 66$.

Brush Creek formation, Carboniferous, West Virginia: Hennen and Reger, 527.

Buckingham series, pre-Cambrian, Quebec: Wilson, 1315.

Buena Vista member, Carboniferous, Ohio and Kentucky: Morse and Foerste, 867.

Buffalo sandstone, Carboniferous, West Virginia: Hennen and Reger, 527; Krebs and Teets, 697.

Bulkley eruptives, Cretaccous or Tertiary, British Columbia: Malloch, 802.

Burke formation, Algonkian, Idaho and Montana: Calkins and Jones, 192.

Burlington limestone, Mississippian, Mississippi Valley: Weller, 1270.

Burlington terrane, Carboniferous, Iowa: Keyes, 661.

Burnett formation, Tertiary, Washington: Daniels, 308

Burton formation, Cambrian, British Columbia: Burling, 157; Schofield, 1041, 1043.

Bushberg sandstone, Mississippian, Mississippi Valley: Weller, 1270.

Buxton formation, Carboniferous, Oklahoma: Buttram, 178.

Byram gneiss, pre-Cambrian, New Jersey: Bayley et al., 66 .

Cabot Head member, Silurian, Ontario: Williams, 1301, 1303.

Cabots Head shale member, Silurian, New York and Ontario: Schuchert, 1054.

Cache Creek group, Carboniferous, British Columbia: Drysdale, 369 .
Cache Creek series, Carboniferous, British Colum bia: Bateman, 61.

Cache Lake beds, Tertiary (Pliocene), California: Dickerson, 340.

Cahil sandstone, Jurassic?, California: Lawson, 724.

Calaveras group, Carboniferous, California: Ferguson, 417.

Calera limestone member, Jurassic?, California, Lawson, 724.

Callaway limestone, Devonian, Missouri: Branson, 118.

Cambric period, Lake Superior region: Keyes, 662

Cambridge slate, Massachusetts: Sayles, 1034

Cambridge slates, Permian, Massachusetts: Clapp, 222

Camden chert, Devonian, Tennessee: Wade, 1239.

Camillus beds, Silurian, New York: Hopkins, 571.

Camillus shale, Silurian, New York: Houghton 577; Luther, 775.

Campbells Creek limestone, Carboniferous, West Virginia: Krebs and Teets, 697.

Campus formation, Pleistocene, California: Lawson, 724.

Canajoharie shale, Ordovician, Nंew York: Cushing and Ruedemann, 296.

Cannelton limestone, Carboniferous, West Virginia: Krebs and Teets, 697.

Cannonball marine member, Tertiary, North Dakota: Lloyd, 758.

Cannonball member, Tertiary: Knowlton, 692.

Cape Ann granite, Mississippian or Pennsylvanian, Massachusett: Clapp, 222.

Cape Horn formation, Carboniferous, California: Ferguson, 417.

Carbonado formation, Tertiary, Washington: Daniels, 308 .

Carbondale formation, Pennsylvanian, Illinois: Blatchley, 98, 100; Hinds, 543.

Cardiff shale, Devonian, New York: Houghton, 577; Luther, 775.

Cardiff shales, Devonian, New York: Hopkins, 571.

Cardium sandstones, Cretaceous, Alberta: Dowling, $362,364$.

Caribbean limestone, Tertiary, Costa Rica: MacDonald, 788.

Carlile shale, Cretaceous, Wyoming: Barnett, 40 .

Carolina gneiss, pre-Cambrian, Georgia: Hopkins 568.

Carrizo formation, Algonkian?, Texas: Richardson, 999.

Cashaqua shale, Devonian, New York: Houghton, 577; Luther, 775.

Casper formation, Carboniferous, Wyoming: Barnett, 41.

Cassville plant shale, Permo-Carboniferous, West Virginia: Krebs and Teets, 697.

Castile gypsum, Permian, Texas: Richardsion, 999. Catahoula sandstone, Tertiary, Texas: Deussen, 336.

Cataract formation, Silurian, New York and Onta. rio: Schuchert, 1054.

Cataract formation, Silurian, Ontario: Williams, 1301, 1303.

Cathedral formation, Cambrian, British Columbia: Allan, 5, 6 .

Catskill series, Devonian, West Virginia: Hennen and Reger, 527. 
Cedar vol canic series, Tertiary (Oligocene), British Columbia: Camsell, 197.

Cedar District formation, Cretaceous, British Columbia: Clapp, 225.

Cedar Valley limestones, Devonian, Iowa: Keyes, 657.

Chancellor formation, Cambrian, British Columbia: Allan, 5, 6 .

Channahon limestone, Silurian, Illinois: Savage, 1031.

Chanute shale, Pennsylvanian, Iowa: Tilton, 1170. Chapman sandstone, Devonian, Maine: Clarke, 244.

Charleton formation, Ordovician, Anticosti Island: Twenhofel, 1190

Chattanooga. shale, Devonian, Kentucky: Munn, 869.

Chattanooga shale, Devonian, Tennessee: Drake, 366; Wade, 1239.

Chattanooga terrane, Carboniferous, Towa: Keyes, 661 .

Chehalis formation, Eocene, California and Oregon: Arnold and Hannibal, 22.

Chemung series, Devonian, West Virginia: Hennen and Reger, 527.

Chemungan series: Keyes, 661 .

Cherokee formation, Pennsylvanian, Oklahoma: Smith, 1098 .

Cherokee shale, Carboniferous, Missouri: Greene, 494.

Cherokee terrane, Carboniferous, Iowa: Keyes, 661. Cherryvale shale, Pennsylvanian, Iowa: Tilton, 1170.

Cherry Valley (Agoniatites) limestone, Devonian, New York: Hopkins, 571.

Chester group, Carboniferous, Kentucky: Bryant, 147.

Chester group, Mississippian, Illinois: Blatchley, 100; Weller, 1269.

Chester group, Mississippian, Kentucky: Bryant, 147.

Chester group, Mississipian, Mississippi Valley: Weller, 1270 .

Chester Valley limestone, Cambro-Ordovician, Pennsylvania: Bliss and Jonas, 101.

Chickamauga limestone, Ordovician, Virginia: Stose, 1152

Chickies formation, Cambrian, Pennsylvania: Bliss and Jonas, 101.

Chico, Cretaceous, California: Dickerson, 340.

Chico formation, Cretaceous, California: Arnold and Garfias, 21; Lawson, 724; Pack and English, 903.

Chico group, Cretaceous, California: Dickerson, 341.

Chico group, Cretaceous, Oregon: Winchell, 1320.

Chicotte formation, Silurian, Anticosti Island: Twenhofel, 1190

Chilton sandstone, Carboniferous, West Virginia: Krebs and Teets, 697.

Chimneyhill formation, Oklahoma: Reeds, 986.

Chipola marl, Tertiary, Florida: Vaughan and: Cooke, 1235.

Chisna formation, Carboniferous; Alaska: Moffit, 854.

Chouteau limestone, Mississippian, Mississippi Valley: Weller, 1270.

Chouteau terrane, Carboniferous, Iowa: Keyes, 661.

Chugwater formation, Triassic?, Wyoming: Barnett, 41.
Cincinnati group, Ordovician, Ontario: Williams, 1301.

Cisco formation, Carboniferous, Texas: Udden, 1202.

Claggett formation, Cretaceous, Montana: Bowen, 103, 104, 105; Stebinger, 1126.

Claggett shales, Cretaceous, Alberta: Dowling, 362, 364.

Claiborne group, Eocene, Georgia: Berry, 80.

Claiborne group, Eocene, Texas: Jeussen, 336.

Clallam formation, Oligocene and Miocene, Washington: Lupton, 774.

Claremont shale, Miocene, California: Lawson, 724.

Clarenville series, Ordovician, Newfoundland: Van Ingen, 1222.

Clarion fire clay, Carboniferous, West Virginia: Hennen and Reger, 527.

Clarion sandstone, Carboniferous, West Virginia: Hennen and Reger, 527.

Clark Fork beds, Tertiary, Wyoming: Granger, 485. Clarksburg limestone, Penusylvanian, West Virginia: Krebs and Teets, 697.

Clarno formation, Eocene, Oregon: Collier, 266.

Clear Fork formation, Carboniferous, Texas: Case, 208.

Clermont terrane, Ordovician, Iowa: Keyes, 661.

Cleveland shalc, Devonian, Ohio: Burroughs, 160.

Clinch sandstone, Silurian, Virginia: Stose, 1152.

Clinton formation, Silurian, Michigan: Smith, 1108.

Clinton formation, Silurian, New York: Schuchert, 1054.

Clinton formation, Silurian, Ontario: Williams, 1303.

Clinton-Rochester shales, Silurian, New York: Họpkins, 571.

Clore formation, Mississippian, Illinois: Weller, 1269.

Clore formation, Mississippian, Mississippi Valley: Weller, 1270

"Cloverly" formation, Cretaceous, Wyoming: Barnett, 39, 41; Hewett, 534.

Clyburn formation, pre-Cambrian?, Cape Breton Island: Wright, 1350 .

Coalburg sandstone, Carboniferous, West Virginia: Krebs and Teets, 697.

Cobalt conglomerate, pre-Cambrian, Canada: Coloman, 262.

Cobalt series, pre-Cambrian, Ontario: Burrows and Hopkins, 164; Collins, 269.

Cobalt series, pre-Cambrian, Ontario: Miller and Knight, 848 .

Cobalt series, pre-Cambrian, Quebec: Wilson, 1313 , 1314.

Cobequid group, Nova Scotia:" Bell, 77.

Cobleskill dolomite, Silurian, New York: Hopkins, 571.

Cobleskill limestone, Silurian, New York: Houghton, 577.

Cobleskill waterlime, Silurian, New York: Luther, 775.

Coconino sandstone, Carboniferous (Pennsylvanian), Arizona: Hill, 539; Noble, 880 .

Coffee sand member, Cretaceous, Gulf States: Stephenson, 1128.

Coggan terrane, Devonian, Iowa: Keyes, 661 .

Coldbrook formation, Cambrian?, Quebec: Hayes, 523. 
Coldbrookian terrane, Cambrian, New Brunswick: Matthew, 816 .

Coldwater formation, Mississippian, Michigan: Cook, 273.

Coldwater group, Tertiary, British Columbia: Drysdale, 369 .

Coldwater series, Tertiary (Oligocene), British Columbia: Camsell, 197.

Coldwater series, Oligocene, British Columbia: Rose, 1016.

Coldwater shale, Mississippian, Michigan: Smith, 1108; Sherzer, 1081.

Colesburg terrane, Silurian, Iowa: Keyes, 661.

Collingwood formation, Ordovician, Ontario: Raymond, 980.

Coralville terrane, Devonian, Iowa: Keyes, 661.

Coloradan series: Keyes, 661.

Colorado formation, Cretaceous, Wyoming: Hewett, 534 .

Colorado shale, Cretaceous, Montana: Bowen, 103, $104,105$.

Colquitz gneiss, British Columbia: Clapp, 227.

Colquitz gneiss, Jurassic, British Columbia: Clapp, 223; Clapp and Cooke, 230.

Columbia lava, Miocene, Oregon: Collier, 266.

Colwood sands and gravels, Pleistocene, British Columbia: Clapp, 223, 225, 227.

Comanchan series: Keyes, 661 .

Comanche series, Cretaceous, Texas: Richardson, 999.

Conemaugh series, Carboniferous, West Virginia: Hennen and Reger, 527; Krebs and Teets, 697.

Connellsville sandstone, Carboniferous, West Virginia: Hennen and Reger, 527; Krebs and Teets, 697.

Connoquenessing (Lower) sandstone, Carboniferous, West Virginia, Hennen and Reger, 527.

Connoquenessing (Upper) sandstone, Carboniferous, West Virginia: Hennen and Reger, 527.

Cook Mountain formation, Eocene, Texas: Deussen, 336.

Cooper marl, Eocene, South Carolina: Rogers, 1013.

Cooper marl, Tertiary, South Carolina: Stephenson, 1129.

Copley meta-andesite, Devonian or older, California: Ferguson, 416.

Coppermine series, Canạda: Sandberg, 1027.

Coralville limestone, Devonian, Iowa: Keyes, 657.

Cordova sands and gravels, Pleistocene, British Columbia: Clapp, 223, 227.

Cornishville limestone, Ordovician, Kentucky: Foerste, 427.

Cornishville member, Ordovician, Kentucky: Miller, 843.

Cornwall ("Pequanac") shale, Devonian, New Jersey: Bayley et al., 66 .

Corral Creek formation, pre-Cambrian, Alberta: Allan, 5.

Corral Creek formation, pre-Cambrian, British Columbia: Allan, 6.

Corryville-Arnheim, Ordovician, Indiana: Cumings and Galloway, 295.

Corson terrane, pre-Cambrian, Iowa: Keyes, 661 .

Cortlandt series, New York: Fettke, 420.

Cougar formation, Beltian, British Columbia: Daly, 306.
Coutchiching, pre-Cambrian, Lake Superior region: Leith, 732.

Coutchiching series, pre-Cambrian, Ontario: Lawson, 721.

Coutchichingan series, pre-Cambrian, Lake Suporior region: Keyes, 662 .

Cowaselon clay, Quaternary, New York: Smith, 1094.

Crab Orchard shales, Silurian, Kentucky: Morse and Foerste, 867.

Craghead Creek shales, Devonian, Missouri: Branson, 118.

Cranberry formation, Cretaceous, British Columbia: Clapp, 225.

Crescent formation, Eocene, Washington: Lupton, 774.

Creston formation, pre-Cambrian, British Columbia: Schofield, 1039, 1043.

Creston red shale, Permo-Carboniferous, West Virginia: Krebs and Teets, 697 .

Crill chalk, Cretaceous, Iowa: Keyes: 665 .

Crill terrane, Cretaceous, Iowa: Keyes, 661.

Croixan series: Keyes, 661 .

Croixan series, Cambrian, Lake Superior region: Keyes, 662.

Croton Falls hornblendite, New York: Fettke, 420.

Crowsnest volcanics, Cretaceous, Alberta: MacKenzie, 792, 794.

Cumberland quartzite, pre-Cambrian, Rhode Island and Massachusetts: Warren and Powers, 1256.

Curdsville member, Ordovician, Kenţucky: Foerste, 427.

Cusseta sand member, Upper Cretaceous, Georgia: Berry, 80 .

Cutler formation, Permian?, Colorado: Cross and Larsen, 290.

Cuyahoga formation, Carboniferous, Ohio and Kentucky: Morse and Foerste, 867.

Cynthiana formation, Ordovician, Kentucky: Foerste, 427; Miller, 843.

Cypress sandstone, Mississippian, Illinois: Blatchley, 100 .

Cyrene member, Silurian, Illinois: Savage, 1031.

Dakota formation, Cretaceous, Alberta: Dowling, $362 ; 364$.

Dakota (?) formation, Cretaceous, Alberta: MacKenzie, 792, 794.

Dakota formation, Cretaceous, New Mexico: Winchester, 1324.

Dakota sandstone, Cretaceous, Minnesota: Grout and Soper, 502 .

Dakota sandstone, Cretaceous, New Mexico: Kirk, 683.

Dakota sandstone, Cretaceous, Utah: Lupton, 773. Dakota sandstone, Cretaceous, Wyoming: Barnett, 40.

Dakotan series: Keyes, 661 .

Dalhousie formation, Devonian, New Brunswick: Clarke, 244.

Dallas deposits, Pleistocene, Towa: Tilton, 1171.

Davis formation, Cambrian, Missouri: Lee, 727.

Decatur limestone, Silurian, Tennessee: Wade, 1239.

De Cew limestone, Silurian, Ontario: Williams, 1303. 
De Cew member, Silurian, New York: Schuchert, 1054.

Decker limestone, Silurian, New Jersey: Bayley et al., 66 .

Decorah shale, Ordovician, Minnesota: Grout and Soper, 502 .

Decorah terrane, Ordovician, Iowa: Keyes, 661.

Decota sandstone, Carboniferous, West Virginia: Krebs and Teets, 697 .

De Courcy formation, Cretaceous, British Columbia: Clapp, 225.

Dedham granite, Massachusetts: Loughlin and Hechinger, 767.

Deep Kill shale, Ordovician, New York: Cushing and Ruedemann, 296.

De Kalb limestone, Pennsylvanian, Iowa: Tilton, 1170.

Dekkas andesite, Triassic, California: Boyle, 113.

Delaware Mountain formation, Permian, Texas: Richardson, 999.

Dennys formation, Silurian, Maine: Bastin and Williams, 60 .

Derby formation, Cambrian, Missouri: Lee, 727.

Des Moines series: Keyes, 601.

Detroit River scries, Devonian, Michigan: Cook, 273.

Detroit River scries, Silurian, Michigan: Sherzer, 10\$1; Smith, 1108.

Dewey limestone, Carboniferous, Oklahoma: Buttram, 178.

Dewitt fórmation, Tertiary, Texas: Deussen, 336 .

Diamond IIill felsite, Carboniferous, Rhode Island and Massachusetts: Warren and Powers, 1256.

Diamond Rock quartzite, Cambrian, New York: Cushing and Ruedemann, 296.

Dighton conglomerate, Permian, Massachusetts: Loughlin and Hochinger, 767.

Dixon limestone, Silurian, Tennessec: Drake, 366; Wade, 1239.

Dockum formation, Triassic, Texas: Case, 208.

Dodge terrane, Tertiary, Iowa: Keyes, 661 .

Doerun formation, Cambrian, Missouri: Lee, 727.

Dolores formation, Triassic, Colorado: Cross and Larsen, 290.

Doré series, pre-Cambrian, Ontario: Miller and Knight, 848 .

Dothan formation, Jurassic, Oregon: Diller, 352; Winchell, 1320.

Double Mountain formation, Permian, Texas: Case, 208.

Dovre moraine, Pleistocene, North Dakota: Simpson, 1090.

Dox sandstone, Algonkian, Arizona: Noble, 880 .

Dresbach formation, Upper Cambrian (St. Croixan), Upper Mississippi Valley: Walcott, 1244.

Dresbach sandstone, Cambrian, Minnesota: Grout and Soper, 502.

Dresbach tcrrane, Cambrian, Iowa: Keyes, 661.

Dubuque terrano, Quaternary, Jowa: Keyes, 661.

Dundee formation, Devonian, Michigan: Sherzer, 1081.

Dundee limestone, Devonian, Michigan: Cook, 273; Smith, 1108 .

Dunkald series, Permo-Carboniferous, West Virginia: Krebs and Teets, 697.

Dunkirk shale, Devonian, New York: Houghton, 577.
Duplin marl, Miocene, South Carolina: Rogers, 1013.

Eagle formation, Cretaceous, Montana: Bowen, 103.

Eagle granodiorite, Jurassic, British Columbia: Camsell, 197.

Eagle limestone, Carboniforous, West Virginia: Krebs and Teets, 697 .

Eagle sandstone, Cretaceous, Montana: Bowen, $104,105$.

Eastern Head formation, Ordovician, Newfoundland: Van Ingen, 1222.

East Grecnwich granite group, Rhode Island: Loughlin and Hechinger, 767.

East Lynn sandstone, Pennsylvanian, West Virginia: Krebs and Teets, 697.

Eastport formation, Silurian, Maine: Bastin and Williams, 60

East Wellington sandstone, Cretaceous, 3ritish Columbia: Clapp, 225.

Eau Claire formation, Upper Cambrian (Si. Croixan), Uppor Mississippi Valley: Walcott, 1244.

Eddy Hill grit, Cambrian, New York: Cushing and Ruedemann, 296.

Eden formation, Ordovician, Kentucky: Foerste, 427; Miller, 843

Eden group, Ordovician, Indiana: Cumings and Galloway, 295.

Edgewood formation, Silurian, Illinois, Missouri: Savage, 1031.

Edisto marl, Miocene, South Carolinn: Rogers, 1013.

Edmonton formation, Cretaceous, Canada: Brown, 133.

Edmonton scrics, Cretaceous, Alberta: Dowling, 362,364 .

Edmunds formation, Silurian, Maine: Bastin and Williams, 60 .

Elbert formation, Devonian?, Colorado: Cross and Larsen, 290.

Eldon formation, Cambrian, British Columbia: Allan, 5,6 .

Elgin sandstone, Carboniferous, Oklahoma: Buttram, 178.

Elgin terrane, Ordovicion, Iowa: Keycs, 661.

Elk fire clay, Pennsylvanian, West Virginia: Krebs and Teets, 697 .

Elk Lick limestone, Carboniferous, West Virginia: Hennen and Reger, 527; Krebs and Teets, 697.

Elkhorn beds, Ordovician, Indiana: Shideler, 1082.

Elko formation, Ordovician and Silurian?, British Columbia: Schofield, 1041.

Elko formation, Silurian, Ordovician, or Cambrian, British Columbia: Schofield, 1043.

Elliott Cove formation, Cambrian, Newfoundland: Van Ingen, 1222.

Ellis formation, Jurassic, Montana: Bowen, 104.

Ellis Bay formation, Ordovician, $\Lambda$ nticosti Island: Twenhofel, 1190.

Elm Point limestone, Devonian, Manitoba: Kindle, 676.

El Paso limestone, Ordovician, Texas: Richardson, 999.

Elysian moraine, Pleistocene, North Dakota: Simpson, 1090.

Eminence formation, Cambrian, Missouri: Lee, 727.

English Head formation, Ordovician, $\Lambda$ nticosti Island: Twenhofel, 1190. 
Eparchæan interval, pre-Cambrian, Lake Superior region: Leith, 732 .

Epicene series: Keyes, 661.

Erian series: Keyes, 661.

Esmeralda formation, Tertiary, N̦evada: Buwalda, 183.

Essex limestone, Silurian, Illinois: Savage, 1031.

Etchegoin group, Neocene, California: Anderson and Martin, 18.

Etcheminian, Cambrian, Quebec: Hayes, 523.

Etcheminian terrane, Cambrian, New Brunswick: Matthew, 816.

Etheline volcanics, Tertiary, British Columbia: MacKenzie, 793.

Eutaw formation, Cretaceous, Gulf States: Stephenson, 1128.

Eutaw formation, Cretaceous, Tennessee: Drake, 366.

Eutaw formation, Upper Cretaceous, Georgia: Berry, 80.

Evanston formation, Cretaceous or Tertiary, Wyoming: Schultz, 1058.

Ewing limestone, Carboniferous, West Virginia: Hennen and Reger, 527; Krebs and Teets, 697.

Extension formation, Cretaceous, British Columbia: Clapp, 225.

Fairview formation, Cambrian, British $\cdot$ Columbia: Allan, 5,6 .

Farnham formation, Ordovician, Quebec: Dresser, 367.

Faulconer limestone, Ordovician, Kentucky: Foerste, 427.

Faulconer member, Ordovician, Kentucky: Miller, 843.

Fayette terrane, Devonian, Iowa: Keyes, 661 .

Fayetteville formation, Mississippian, Oklahoma: Smith, 1098.

Fayetteville shale, Mississippian, Oklahoma: Snider, 1114.

Fergus Falls moraine, Pleistocene, North Dakota: Simpson, 1090.

Fernando formation, Miocene-Pliocene, California: Arnold and Garfias, 21.

Fern Glen formation, Mississippian, Mississippi Valley: Weller, 1270.

Fernie formation, Jurassic, Alberta: MacKenzie, 792,794 .

Fernie shale, Jurassic, Alberta: Allan, 5.

Fernie shales, Jurassic, Alberta: Dowling, 362, 364.

Fernvale formation, Ordovician, Tennessee: Drake, 366; Wade, 1239.

Ferron sandstone member, Cretaceous, Utah: Lupton, 773.

Fiddler's Green limestone, Silurian, New York: Hopkins, 571.

Flanagan formation, Ordovician, Kentucky: Miller, 843.

Flat Rock dolomite, Silurian, Michigan: Sherzer, 1081.

Flat Rock dolomite, Silurian, Ontario: Stauffer, 1123.

Fleming clay, Miocene, Texas: Deussen, 336.

Forbes terrane, Carboniferous, Iowa: Keyes, 661.

Fordham gneiss, pre-Cambrian, New York: Berkey and Healey, 79; Fettke, 420; Fuller, 441.

Forelle(?) limestone, Carboniferous, Wyoming: Barnett, 41.
Fort Payne chert, Mississippian, Tennessee: Drake, 366; Wade, 1239.

Fort Seott limestone, Pennsylvanian, Oklahoma: Smith, 1098.

Fort Union formation, Saskatchewan: Rose, 1017.

Fort Union formation, Eocene, North Dakota: Leonard, 737.

Fort Union formation, Eocene, Wyoming: Hewett, 534.

Fort Union formation, Tertiary, Montana: Bauer, 64; Bowen, 105.

Fort Union formation, Tertiary, North Dakota: Lloyd, 758 .

Fort Union formation, Tertiary, South and North Dakota: Calvert et al., 193.

Fort Union formation, Tertiary, Wyoming: Barnett, 41.

Fox Hills formation, Cretaceous: Brown, 133; Knowlton, 692.

Fox Hills formation, Cretaceous, Wyoming: Barnett, 39.

Fox Hills sandstone, Cretaceous: Stanton, 1122.

Fox Hills sanđstone, Cretaceous, North Dakota: Leonard, 737; Lloyd, 758.

Fox Hills sandstone, Cretaceous, South Dakota: Calvert et al., 193.

Fox Hills sandstone, Cretaceous, Wyoming: Barnett, 40 .

Fox Hills(?) sandstone, Cretaceous, Wyoming: Barnett, 41.

Franciscan, Jurassic, California: Dickerson, 340.

Franciscan formation, Jurassic?, California: Pack and English, 903.

Franciscan group, Jurassic?, California: Lawson, 724

Franconia formation, Upper Cambrian (St. Croixan), Upper Mississippi Valley: Walcott, 1244.

Franconia sandstone, Cambrian, Minnesota: Grout and Soper, 502.

Franey granite, Cape Breton Island: Wright, 1350.

Franklin limestone, pre-Cambrian, New Jersey: Bayley et al., 66 .

Fredericksburg group, Cretaceous, Texas: Richardson, 999.

Freeport (Lower) limestone, Carboniferous, West Virginia: Hennen and Reger, 527.

Freeport (Lower) sandstone, Carboniferous, West Virginia: Hennen and Reger, 527.

Freeport (Upper) limestone, Carboniferous, West Virginia: Hennen and Reger, 527; Krebs and Teets, 697.

Freeport (Upper) sandstone, Carboniferous, West Virginia: Hennen and Reger, 527; Krebs and Teets, 697 .

Friar's Hillgravels and marls, Pleistocene, Antigua: Brown, 130.

Frontier formation, Cretaceous, Wyoming: Schultz, 1058.

Fulton shale, Ordovician, Kentucky: Foerste, 427. Fuson shale, Cretaceous, Wyoming: Barnett, 40.

Gabriola formation, Cretaceous, British Columbia: Clapp, 225.

Galena dolomite, Ordovician, Illinois: Cox, 278.

Galena formation, Ordovician, Illinois: Cady, 185.

Galena limestone, Ordovician, Minnesota: Grout and Soper, 502. 
Galena terrane, Ordovician, Towa: Keyes, 661.

Galesburg shale, Pennsylvanian, Iowa: Tilton, 1070.

Galice formation, Jurassic, Oregon: Diller, 352; Winchell, 1320.

Galton series, pre-Cambrian, British Columbia: Burling, 157; Schofield, 1043.

Gamachian series, Ordovician, Anticosti Island: Twenhofel, 1190

Gardeau flags and shales, Devonian, New York: Luther, 775 .

Gardeau shale, Devonian, New York: Houghton, 577.

Gardiners clay, Quaternary, New York: Fuller, 441.

Garrard sandstone, Ordovician, Kentucky: Miller, 843.

Gasconade formation, Cambrian, Missouri: Lee, 727.

Gasport limestone, Silurian, Ontario: Williams, 1303.

Gasport member, Silurian, New York: Schuchert, 1054.

Gateway formation, pre-Cambrian, British Columbia: Schofield, 1040, 1043.

Gatun formation, Tertiary, Costa Rica: MacDonald, 788.

Gavilan limestone, pre-Franciscan (Mesozoic), California: Lawson, 724 .

Gebo formation, Cretaceous, Wyoming: Hewett, 534

Genesee beds, Devonian, New York: Houghton, 577.

Genesee black shale, Devonian, New York: Luther, 775 .

Genundewa limestone, Devonian, New York: Houghton, 577; Luther, 775.

Georgian series: Keyes, 661.

Gilboy sandstone, Pennsylvanian, West Virginia: Krebs and Teets, 697.

Giles formation, Devonian, Virginia: Stose, 1152.

Glacier division, Beltian, British Columbia: Daly, 306.

Gladeville sandstone, Pennsylvanian, Virginia: Butts, 179, 180

Glen Park limestone, Mississippian, Mississippi Valley: Weller, 1270.

Glens Falls formation, Ordovician, New York: Raymond, $980^{\circ}$.

Glens Falls limestone, Ordovician, New York: Cushing and Ruedemann, 296.

Glenwood terrane, Ordovician, Iowa: Keyes, 661.

Goldenville formation, pre-Cambrian, Nova Scotia: Faribault, 405.

Goodsir formation, Ordovician, British Columbia: Allan, 6.

Goodsir shale, Ordovician, British Columbia: Allan, 5.

Gower limestone, Silurian, Iowa: Savage, 1031.

Goweran series: Keyes, 661 .

Grafton sandstone, Carboniferous, West Virginia:

Hennen and Reger, 527; Krebs and Teets, 697.

Grainger shale, Mississippian, Virginia: Butts, 179.

Grand Canyon series, Algonkian, Arizona: Noble, 880.

Grand Rapids (Lower), Mississippian, Michigan: Cook, 273.
Grand Rapids (Lower) formation, Mississippian, Michigan: Smith, 1108.

Grand Rapids (Upper) formation, Mississippian, Michigan: Smith, 1108.

Grandfield conglomerate, Tertiary or Quaternary, Oklahoma: Munn, 869.

Graneros shale, Cretaceous, Wyoming: Barnett, 40. Grants Mills granite, Devonian, Rhode Island and Massachusetts: Warren and Powers, 1256.

Grassy shale, Carboniferous, Iowa: Keyes, 661.

Grassy terrane, Carboniferous, Iowa: Keyes, 661 .

Gravel Head formation, Ordovician, Newfoundland: Van Ingen, 1222.

Gray Bull beds, Tertiary, Wyoming: Granger, 485.

Greenbrier limestone, Carboniferous, Virginia: Stose, 1152

Greenbrier limestone, Carboniferous, West Virginia: Hennen and Reger, 527.

Greendale member, Ordovician, Kentucky: Foerste 427.

Greenfield dolomite, Silurian, Michigan: Sherzer, 1081 .

Greenfield dolomite, Silurian, Ontario: Stauffer, 1123.

Greenhorn formation, Cretaceous, Wyoming: Barnett, 40 .

Green Pond conglomerate, Silurian, New Jersey: Bayley et al., 66 .

Green River formation, Eocene, Wyoming: Schultz, 1058.

Green River formation, Tertiary, Colorado and Utah: Woodruff and Day, 1.333.

Grenville limestone, pre-Cambrian, Quebec: Wilson, 1315 .

Grenville series, pre-Cambrian, Canada: Coleman, 262.

Grenville series, pre-Cambrian, New York: Cushing and Ruedemann, 296; Miller, 850.

Grenville series, pre-Cambrian, Ontario: Coleman, 264; Miller and Knight, 848.

Grenville series, pre-Cambrian, Quebec: Wilson, 1314.

Grimsby member, Silurian, Ontario: Williams, 1303.

Guelph formation, Silurian, Ontario: Williams, 1303.

Gunflint formation, Algonkian, Minnesota: Grout and Soper, 502.

Gun River formation, Silurian, Anticosti: Schuchert, 1054; Twenhofel, 1190.

Gwinn series, pre-Cambrian, Michigan: Allen, 14; Allen and Barrett, 15.

Faida formation, Cretaceous, British Columbia: MacKenzie, 793.

Haida member, Jurassic, British Columbia: Clapp, 227.

Haines granite, post-Triassic, Oregon: Grant and Cady, 487.

Hakatai shale, Algonkian, Arizona: Noble, 880.

Halifax formation, pre-Cambrian, Nova Scotia: Faribault, 405.

Hambre sandstone, Miocene, California: Lawson, 724.

Hamburg oolite, Mississippian, Mississippi Valley: Weller, 1270.

Hamilton formation, Devonian, Ontario: Williams, 1302. 


\section{BIBLIOGRAPHY OF NORTH AMERICAN GEOLOGY, 1914.}

Familton limestone, Devonian, Illinois: Cady, 185; Ekblaw, 385.

Hancock limestone, Devonian, Virginia: Stose, 1152.

Hanford formation, Cambrian, Newfoundland: Van Ingen, 1222.

Hannibal sandstone, Mississippian, Mississippi Valley: Weller, 1270 .

Hannibal terrace, Carboniferous, Iowa: Keyes, 661. Hanover shale, Devonian, New York: Houghton, 577.

Harbor Hill moraine, Quaternary, New York: Fuller, 441.

Hardin sandstone, Devonian, Tennessee: Wade, 1239.

Hardin sandstone member, Devonian, Tennessee: Drake, 366 .

Hardman fire clay, Carboniferous, West Virginia: Hennen and Reger, 527.

Hardyston quartzite, Cambrian, New Jersey: Bayley et $a 7 . ., 66$.

Harlan sandstone, Pennsylvanian, Virginia: Butts. $179,180$.

Harmon, Ordovician, Indiana: Cumings and Galloway, 295.

Harmon Hill gneiss, pre-Cambrian; Vermont: Gordon, 476.

Harrison granodiorite gneiss, New York: Fettke, 420.

Hartshorne formation, Pennsylvanian, Arkansas and Oklahoma: Smith, 1097.

Hartshorne sandstone, Pennsylvania, Oklahoma: Snider, 1113.

Hartwick terrane, Silurian, Iowa: Keyes, 661.

Haslam formation, Cretaceous, British Columbia: Clapp, 225.

Hastings series, pre-Cambrian, Ontario: Miller and Knight, 848.

Hatch shales and flags, Devonian, New York: Luther, 775 .

Hawarden shales, Cretaceous, Iowa: Keyes, 655.

Hawarden terrane, Cretaceous, Iowa: Keyes, 661 .

Hawthorn formation, Tertiary, Florida: Vaughan and Cooke, 1235.

Hazelton group, Jurassic, British Columbia: McConnell, 781; Malloch, 802 .

Hector formation, pre-Cambrian, British Columbia: Allan, 6.

Hector formation, pre-Cambrian, Alberta: Allan, 5.

Helderbergian limestone, Devonian, New York: Hopkins, 571.

Hell Creek formation, Cretaceous: Brown, 133.

Hempstead gravel, Quaternary, New York: Fuller, 441.

Henrietta formation, Carboniferous, Missouri: Greene, 494.

Henrietta terrane, Carboniferous, Iowa: Keyes, 661. Hercules shale member, Miocene, California: Lawson, 724.

Hermansville limestone, Ordovician, Michigan: Smith, 1108.

Hermitage formation, Ordovician, Tennessee: Drake, 366 .

Hermosa formation, Pennsylvanian; Colorado: Cross and Larsen, 290.

Herod gravel member, Quaternary, New York: Fuller, 441.
Hersey red shale member, Silurian, Maine: Bastin, and Williams, 60.

Hertha limestone, Pennsylvanian, Iowa: Tilton, 1070.

High Falls shale, New York: Brown, 140

Hilliard formation, Cretaceous, Wyoming: Schultz, 1058.

Hinckly terrane, Cambrian, Iowa: Keyes, 661.

Hoboken serpentine, pre-Cambrian, New York: Berkey and Healey, 79.

Hodge's Hill calcareous sandstone, Oligocene, Antigua: Brown, 130.

Homewood sandstone, Carboniferous, West Virginia: Hennen and Reger, 527; Krebs and Teets, 697.

Honaker limestone, Cambrian, Virginia: Stose, 1152.

Honna formation, Cretaceous, British Columbia: MacKenzie, 793.

Honna member, Jurassic, British Columbia: Clapp, 227.

Hopkinton dolomite, Silurian, Iowa: Savage, 1031.

Horsethief sandstone, Cretaceous, Montana: Stebinger, 1125, 1126.

Horsetown group, Cretaceous, Oregon: Winchell, 1320.

Hotauta conglomerate, Algonkian, Arizona: Noble, 880.

Hoyt limestone member, Cambrian, New York: Cushing and Ruedemann, 296.

Hudson River.slates, New York: Fettke, 420.

Hueco limestone, Pennsylvanian, Texas: Richardson, 999.

Hull formation, Ordovician, Ontario: Raymond, 980.

Hull terrane, pre-Cambrian, Iowa: Keyes, 661.

Hundred sandstone, Permo-Carboniferous, West Virginia: Krebs and Teets, 697.

Huronian, pre-Cambrian, Canada: Coleman, 262.

Huronian, pre-Cambrian, Ontario: Miller and Kinight, 848.

Huronian conglomerate, pre-Cambrian, Ontario: Coleman, 264.

Huronian series, Algonkian, Minnesota: Grout and Soper, 502.

Euronian (Lower) series, pre-Cambrian, Ontario: Collins, 270.

Huronian (Upper) series, pre-Cambrian, Ontario: Collins, 270.

Huronic period, pre-Cambrian, Lake Superior region: Keyes, 662.

Hygiene sandstone member, Cretaceous: Stanton, 1122.

Illecillewaet quartzite, Beltian, British Columbia: Daly, 306.

Illinoian stage, Pleistocene, Towa: Hay, 522.

Ilo formation, Cretaceous or Tertiary, Wyoming: Hewett, 534 .

Image member, Jurassic, British Columbia: Clapp, 227.

Independence terrane, Devonian, Iowa: Keyes, 661. Indian Ladder beds, Ordovician, New York: Cushing and Ruedemann, 296.

Ingleside chert, Jurassic?, California: Lawson, 724. Ingonish gneiss, pre-Cambrian?, Cape Breton Island: Wright, 1350.

Intermediate limestone, Devonian, Alberta: Allan, 5 . 
Inwood limestone, New York: Fettke, 420.

Inwood limestone, pro-Cambrian, Now York: Berkey and Healey, 79.

Ione beds, Eocene, California and Oregon: Arnold and Hannibal, 22.

Ione formation, Eocene, California: Dickerson, 346; Waring, 1254.

Iowa stage, Pleistocene, Iowa: Hay, 522.

Iowa terrane, Pleistocene, Iowa: Keyes, 661.

Irasburg conglomerate, Ordovician, Vermont: Richardson and Turner, 996; Richardson et al., 997.

Irondequoit limestone, Silurian, New York: Schuchert, 1054.

Irondequoit member, Silurian, Ontario: Williams, 1303.

Itasca moraine, Pleistocene, North Dakota: Simpson, 1090.

Jackson formation, Eocene, Texas: Deussen, 336.

Jacksonburg limestone, Ordovician, New Jersey: Bayley et al., 66.

Jacob sand, Quaternary, New York: Fuller, 441.

Jacobsville sandstone, Cambrian, Michigan: Smith, 1108.

Jameco gravel, Quaternary, New York: Fuller, 441.

James. River formation, Ordovician, Nova Scotia. Williams, 1300.

Jasper terrane, pre-Cambrian, Iowa: Keyes, 661 .

Jefferson limestone, Devonian, British Columbia: Schofield, 1041, 1043.

Jefferson City formation, Cambrian, Missouri: Lee, 727.

Jerseyan drift, Pleistocene, New Jersey: Bayley ct al., 06.

Joes Rock granite, Devonian, Rhode Island and Massachusetts: Warren and Powers, 1256.

Joggins formation, Pennsylvanian, Nova Scotia: Bell, 77.

Johannian division, Cambrian, New Brunswick: Matthew, 816.

John Day formation, Oligocene, Oregon: Collier, 266.

Johnstown cement limestone, Carboniferous, West Virginia: Hennen and Reger, 527 :

Jordan formation, Upper Cambrian (St. Croixan), Upper Mississippi Valley: Walcott, 1244.

Jordan sandstone, Cambrian, Minnesota: G̣rout and Soper, 502.

Jordan terrane, Cambrian, Iowa: Keyes, 661.

Judith River formation, Cretaceous, Montana: Bowen, 103, 104, 105.

Judith River formation, Cretaceous, Montana: Stebinger, 1125, 1126.

Jupiter River formation, Silurian, Anticosti Island: Twenhofel, 1190.

Kaibab limestone, Carboniferous (Pennsylvanian),

Arizona: Hill, 539; Noble, 880 .

Kaibab limestone, Pennsylvanian, Arizona: Gregory, 497 .

Kamloops series, Tertiary, British Columbia: Rose, 1016.

Kamloops volcanic group, Tertiary, British Columbia: Drysdale, 369 .

Kanawha blackfint, Carboniferous, West Virginia: Krebs and Teets, 697 .

Kanawha series, Pennsylvanian, West Virginia: Krebs and T'eets, 697.

Kanouse sandstone, Devonian, New Jersey: Bayley et al., 66.

Kansan drift, Pleistocene, Iowa: Tilton, 1171.

Kansan stage, Pleistocene, Iowa: Hay, 522.

Kansas City formation, Carboniferous, Missouri: Greene, 494.

Katalla formation, Tertiary, Alaska: Fisher and Calvert, 422.

Keewatin, pro-Cambrian, Canada: Coleman, 262.

Keewatin, pro-Cambrian, Ontario: Burrows and Hopkins, 164; Coleman, 264; Collins, 269.

Keewatin complex, pre-Cambrian, Ontario: Miller and Knight, 848 .

Keewatin series, pro-Cambrian, Lake Superior region: Keyes, 662 .

Keewatin series, pre-Cambrian, Ontario: Lawson, 721.

Kelly Island formation, Ordovician, Nowfoundland: Van Ingen, 1222.

Keokuk limestone, Mississippian, Mississippi Valley: Weller, 1270 .

Keokuk terrane, Carboniferous, Iowa: Keyes, 661.

Keewenawan series: Keyes, 661.

Keewenawan series, pre-Cambrian, Lake Superiox region: Keyes, 662.

Keweenawan, pre-Cambrian, Canada: Coleman, 262.

Keweenawan, pre-Cambrian, Ontario: Coleman, 264; Collins, 269; Lawson, 721; Miller and Knight, 848.

Killarney granite, pro-Cambrian, Ontario: Miller and Knight, 848 .

Kimberling shale, Devonian, Virginia: Stose, 1152.

Kimmswick-Plattin limestone, Ordovician, Illinois: Blatchley, 100.

Kinderhook group, Mississippian, Illinois: Blatchley, 100.

Kinderhook group, Mississippian, Mississippi Valley: Weller, 1270.

Kingston formation, pre-Silurian, Quebec: Hayes, 523.

Kingston series, Permian, Massachusetts: Loughlin and Hechinger, 767.

Kitanning (Lower) fire clay, Carbonilerous, W est Virginia: Hennen and Reger, 527.

Kitchener formation, pre-Cambrian; British Columbia: Schofield, 1043.

Kitsalas formation, Triassic?, British Columbia; McConnell, 781.

Kittatinny limestone, Cambrian and Ordovician, New Jersey: Bayley et al., 66 .

Knight formation, Eocene, Wyoming: Schultz, 1058.

Knight formation, Tertiary, Wyoming: Granger, 485.

Knob Hill group, pre-Carboniferous, British Columbia: LeRoy, 738 .

Knox dolomite, Cambrian and Ordovician, Virginia: Stose, 1152.

Knoxville formation; Cretaceous, California: Arnold and Garfias, 21; Lawson, 724.

Knoydart formation, Devonian; Nova Scotia: Williams, 1300.

Koipato formation, Triassic, Nevada: Schrader, 1048 .

Kootenai(?) formation, Cretaceous?, Montana: Bowen, 104 
Kootenay, Cretaceous, Alberta: Allan, 5; Dowling, 364 .

Kootenay formation, Cretaceous, Alberta: Dowling 362; MacKenzie, 792, 794.

Kootenay granite, British Columbia: Schofield, 1040.

Kootenay intrusive: Schofield, 1039.

Kushtaka formation, Tertiary, Alaska: Fisher and Calvert, 422.

Ladore shale, Pennsylvanian, Iowa: Tilton, 1070. Lafayette? formation, Tertiary, New York: Fuller, 441.

Lake Evans series, pre-Cambrian, Quebec: Cooke, 275.

Lake Louise formation, Cambrian, British Columbia: Allan, 5,6 .

Lake Superior sandstone, Cambrian, Michigan: Smith, 1108.

Lakota sandstone, Cretaceous, Wyoming: Barnett, 40.

Lamotte formation, Cambrian, Missouri: Lee, 727.

Lance formation, Cretaceous: Stanton, 1122.

Lance formation, Cretaceous or Eocene, North Dakota: Leonard, 737.

Lance formation, Cretaceous or Tertiary, South and North Dakota: Calvert et al., 193.

Lance formation, Cretaceous or Tertiary, Wyoming: Barnott, 41.

Lance formation, Tertiary: Knowlton, 692.

Lance formation, Tertiary?, Montana: Bauer, 64; Bowen, 103; Rogers, 1012.

Lance formation, Tertiary?, North Dakota: Lloyd, 758.

Lance formation, Tertiary?, Wyoming: Barnett, 39.

Lance Cove formation, Ordovician, Newfoundland: Van Ingen, 1222.

Laona sandstone, Devonian, New York: Houghton 577.

La Plata sandstone, Jurassic, Colorado: Cross and Larsen, 290.

La Plata sandstone, Jurassic, Utah: Lupton, 773.

Laramie formation, Cretaceous: Knowlton, 692.

Largo beds, Tertiary, Wyoming: Granger, 485.

Laurel limestone, Silurian, Tennessee: Drake, 366; Wade, 1239

Laurencic period, pre-Cambrian, Lake Superior region: Keyes, 662 .

Laurentian, pre-Cambrian, Ontario: Coleman, 264; Lawson, 721; Miller and Knight, 848.

Laurentian, pre-Cambrian, Quebec; Wilson, 1314.

Laurie formation, Beltian, British Columbia: Daly, 306.

Lawrence terrane, Carboniferous, Iowa: Keyes, 661.

Lead Creek limestone, Carboniferous, Kentucky: Crider, 281.

Leaf Hills moraine, Pleistocene, North Dakota: Simpson, 1090.

LeClaire terrane, Silurian, Iowa: Keyes, 661.

Lee formation, Pennsylvanian, Kentucky: Munn, 869.

Lee formation, Pennsylvanian, Virginia: Butts, 179, 180.

Leech River formation, Carboniferous?, British Columbia: Clapp, 227; Clapp and Cooke, 230.

Lego limestone, Silurian, Tennessee: Drake, 366; Wade, 1239
Leighton gray shale member, Silurian, Maine: Bastin and Williams, 60.

Leipars limestone, Ordovician, Tennessee: Drake, 366; Wade, 1239.

Leona rhyolite, Pliocene, California: Lawson, 724.

Leray limestone, Ordovician, Quebec and Ontario: Raymond, 980 .

Lexington limestone, Ordovician, Kentucky: Foerste, 427.

Liberty, Ordovician, Indiana: Cumings and Galloway, 295.

Liberty beds, Ordovician, Indiana: Shideler, 1082.

Lime Creek terrane, Devonian, Iowa: Keyes, 661.

Linden formation, Devonian, Tennessee: Drake, 366; Wade, 1239.

Linietta clays, Carboniferous, Kentucky: Morse and Foerste, 867 .

Lipalian time, pre-Cambrian, British Columbia: Walcott, 1246.

L'Islet formation, Cambrian, Quebec: Dresser, 367 .

Lissie gravel, Pleistocene, Texas: Deussen, 336.

Listmore formation, Carboniferous, Nova Scotia: Williams, 1300.

Little Bell Island formation, Ordovician, Newfoundland: Van Ingen, 1222.

Little Falls dolomite, Cambrian, New York: Cushing and Ruedemann; 296.

Little River formation, Quebec: Hayes, 523 .

Livingston formation, Cretaceous: Stanton, 1122.

Lloyd sand, Cretaceous, New York: Fuller, 441.

Lobelville limestone, Silurian, Tennessee: Drake, 366.

Lockatong formation, Triassic, New Jersey: Bayley et al., 66 .

Lockatong formation, Triassic, Pennsylvania and New Jersey: Hawkins, 520 .

Lockport dolomite, Silurian, New York: Schuchert, 1054.

Lockport dolomite, Silurian, Ontario: Williams, 1301.

Lockport limestone, Silurian, New York: Hopkins, 571.

Lockport member, Silurian, Ontario: Williams, 1303.

Logan formation, Carboniferous, Ohio and Kentucky: Morse and Foerste, 867.

Loganian, pre-Cambrian, Ontario: Miller and Knight, 848.

Longwood shale, Silurian, New Jersey: Bayley et $a l ., 66$.

Lorrain granite, pre-Cambrian, Ontario: Miller and Knight, 848.

Lorraine or Maysville, Ordovician, Michigan: Smith, 1108.

Lorraine formations, Ordovician, Quebec and New York: Foerste, 428.

Losee gneiss, pre-Cambrian, New Jersey: Bayley et al., 66.

Lost Cabin formation, Tertiary, Wyoming: Granger, 485.

Louisiana limestone, Mississippian, Mississippi Valley: Weller, 1270.

Louisiana limestone, Mississippian, Missouri: Lee, 727.

Louisiana terrane, Carboniferous, Iowa: Keyes, 661. Lowerre quartzite, New York: Fettke, 420. 
Lowville limestone, Ordovician; Quebec and Ontario: Raymond, 980

Lucas dolomite, Silurian, Michigan: Sherzer, 1081. Lucas dolomite, Silurian, Ontario: Stauffer, 1123.

Lucas limestone, Devonian, Iowa: Keyes, 657.

Lucas terrane, Devonian, Iowa: Keyes, 661 .

Ludlow lignitic member, Tertiary: Knowlton, 692. Ludlowville shale, Devonian, New York: Houghton, 577; Luther, 775.

Lynn volcanics, Devonian or Mississippian, Massachusetts: Clapp, 222.

Lynnfield serpentine, Cambrian?, Massachusetts: Clapp, 222.

Lysite formation, Tertiary, Wyoming: Granger, 485 .

McAdam formation, Silurian, Nova Scotia: Williams, 1300 .

McA lester shale, Pennsylvania, Arkansas and Oklahoma: Smith, 1097

McAlester shale, Pennsylvania, Oklahoma: Snider, 1113.

McAras Brook formation, Carboniferous, Nova Scotia: Williams, 1300.

McCloud formation, Pennsylvanian, California: Boyle, 113.

McElmo formation, Jurassic?, Colorado: Cross and Larsen, 290.

McElmo formation, Jurassic?, Utah: Lupton, 773.

McKim greywacké, pre-Cambrian, Ontario: Coleman, 264 .

McLeansboro formation, Pennsylvanian, Illinois: Blatchley, 98, 100

McMicken, Ordovician, Indiana: Cumings and Galloway, 295 .

McNairy sand member, Cretaceous, Gulf States: Stephenson, 1128.

Madison formation, Ozarkian, Upper Mississippi Valley: Walcott, 1244

Madison (?) limestone, Carboniferous, Montana: Bowen, 104.

Madison limestone, Mississippian, Idaho: Richards and Mansfield, 995.

Madison limestone, Mississippian, Montana: Stone and Bonine, 1149.

Madisonville limestone, Carboniferous, Kentucky: Crider, 284; Hutchinson, 600.

Magothy formation, Cretaceous, Maryland: Berry, 84.

Mahoning sandstone, Carboniferous, West Virginia: Eennen and Reger, 527; Krebs and Teets, 697.

Maidment formation, Ordovician, Newfoundland: Van Ingen, 1222.

Malahat volcanics, Carboniferous?, British Columbia: Clapp, 227; Clapp and Cooke, 230.

Malden sandstone, Carboniferous, West Virginia: Krebs and Teets, 697.

Malignant Cove formation, Ordovician, Nova Scotia: Williams, 1300.

Mancos formation, Cretaceous, New Mexico: Kirk, 683; Winchester, 1324.

Mancos formation, Cretaceous, Utah: Clark, 235.

Mancos shale, Cretaceous, Utah: Lupton, 773.

Manhasset formation, Quaternary, New York: Fuller, 441.

Manhattan schist, New York: Fettke, 420.

Manhattan schist, pre-Cambrian, New York: Berkey and Healey, 79.
Manigotagan granites, pre-Cambrian, Manitoba: Moore, 860

Manitoba formation, Devonian, Manitoba: MacLean and Wallace, 796.

Manitoban formation, Devonian, Manitoba: Kindle, 676.

Manitoulin limestone member, Silurian, New York and Ontario: Schuchert, 1054.

Manitoulin member, Silurian, Ontario: Williams, 1301, 1303.

Manix beds, Pleistocene, California: Buwalda, 181.

Mankomen formation, Carboniferous, Alaska: Moffit, 854 .

Manlius limestone, Silurian, New York: Hopkins, 571.

Mannetto gravel, Quaternary, New York: Fuller, 441.

Mannington sandstone, Permo-Carboniferous, West Virginia: Krebs and Teets, 697.

Manuels formation, Cambrian, Newfoundland: Van Ingen, 1222

Maquoketa shale, Ordovician, Illinois: Blatchlev, 100; Cady, 185; Cox, 278.

Maquoketa shale, Ordovician, Towa: Thomas, 1165.

Maquoketa shale, Ordovician, Minnesota: Grout and Soper, 502

Maquoketan series: Keyes, 661.

Marais des Cygnes terrane, Carboniferous, Iowa: Keyes, 661 .

Marble Bay formation, Triassic or Jurassic, British Columbia: Cairnes, 191; McConnell, 782.

Marble Canyon limestone, Carboniferous, British Columbia: Drysdale, 369

Marcellus black shale, Devonian, New York: Luther, 775.

Marcellus shale, Devonian, New York: Houghton, 577.

Marcellus shales, Devonian, New York: Hopkins' 571.

Marietta (Lower) sandstone, Permo-Carboniferous, West Virginia: Krebs and Teets, 697. .

Marietta (Upper) sandstone, Pcrmo-Carboniferous, West Virginia: Krebs and 'leets, 697.

Marin sandstone, Jurassic?, California: Lawson, 724

Marquettan series, pre-Cambrian, Lako Superior region: Keyes, $\mathbf{6 6 2}$.

Marshall sandstone, Carboniferous, Michigan: Cook, 273.

Marshall sandstone, Mississippian, Michigan: Smith, 1108 .

Martinez formation, Eocene, California: Lawson, 724; Waring, 1254 .

Martinez group, Eoceno, California: Dickerson, 340, 341,342 .

Martinsburg shale, Ordovician, New Jersey: Bayley et al., 66.

Mascall formation, Miocene, Oregon: Collier, 266.

Maysville group, Ordovician, Indiana: Cumings and Galloway, 295.

Maywood clays, Pleistocene, British Columbia: Clapp, 223, 227.

Medina formation, Silurian, New York and Ontario: Schuchert, 1054.

Medina formation, Silurian, Ontario: Williams, 1303.

Meeteetse formation, Cretaceous, Wyoming: Hewett, 534 . 
Menard formation, Mississippian, Illinois: Weller, $1269,1270$.

Mendota formation, Ozarkian, Upper Mississippi Valley: Walcott, 1244.

Meramec group, Mississippian, Illinois: Blatchley, 100.

Meramec group, Mississippian, Mississippi Valley: Weller, 1270.

Merced formation, Pliocene, California: Lawson, 724.

Merrimac schists, Mississippian, Massachusetts: Clapp, 222.

Merritt sand, Pleistocene, California: Lawson, 724.

Mesaverde formation, Cretaceous, New Mexico: Winchester, 1324.

Mesaverde formation, Cretaceous, Utah: Clark, 235.

Mesaverde series, Cretaceous, New Mexico: Kirk, 683.

Metchosin volcanics, Eocene, British Columbia: Clapp, 223, 227.

Mettawee slate, Cambrian, New York: Cushing and Ruedemann, 296.

Michigan series, Mississippian, Michigan: Cook, 273 Smith, 1108.

Middendorf arkose member, Upper Cretaceous, S. Carolina: Berry, 80.

Middlesex black shale, Devonian, New York: Luther, 775.

Middlesex shale, Devonian, New York: Houghton, 577.

Midway formation, Eocene, Texas: Deussen, 336.

Milford granite, Devonian, Rhode Island and Massachusetts: Warren and Powers, 1256.

Milford granite, Rhode Island: Loughlin and Hechinger, 767 .

Millersburg limestone, Ordovician, Kentucky: Foerste, 427.

Millican formation, Algonkian?, Texas: Richardson, 999.

Minnesotan series: Keyes, 661 .

Mispeck formation, Quebec: Hayes, 523

Missi formation, pre-Cambrian, Saskatchewan: Bruce, 144.

Mississippian series: Keyes, 661 .

Missourian series: Keyes, 661.

Moccasin limestone, Ordovician, Virginia: Stose, 1152.

Moencopie formation, Permian?, Arizona: Gregory, 497.

Mohawkian series: Keyes, 661 .

Moira granite, pre-Cambrian, Ontario: Miller and Knight, 848 .

Molas formation, Pennsylvanian, Colorado: Cross and Larsen, 290.

Monongahela series, Carboniferous, West Virginia: Hennen and Reger, 527

Monongahela series, Pennsylvanian, West Virginia: Krebs and Teets, 697.

Monroe formation, Silurian, Michigan: Sherzer, 1081; Smith, 1108;.

Monroe (Lower), Silurian, Michigan: Cook, 273; Sherzer, 1081.

Monroe (Upper) series, Devonian, Michigan: Cook, 273.

"Montana granite," pre-Franciscan (Mesozoic), California: Lawson, 724.
Montana group, Cretaceous, Montana: Stebinger, 1125,1126 .

Montana group, Cretaceous, South Dakota: Calvert et al., 193.

Montanan series: Keyes, 661.

Montauk till member, Quaternary, New York: Fuller, 441.

Monterey formation, Miocene, California: Anderson and Martin, 18.

Monterey group, Miocene, California: Lawson, 724 Monticello terrane, Silurian, Iowa: Keyes, 661 .

Montoya limestone, Ordovician, Texas: Richardson, 999 .

Montrose chert, Carboniferous, Iowa: Keyes, 661.

Montrose chert bed, Mississippian, Mississippi Valley: Weller, 1270

Moose metargillite, Beltian, British Columbia: Daly, 306.

Moose River sandstone, Devonian, Maine: Clarke, 244; Pirsson and Schuchert, 955.

Moraga formation, Pliocene, California: Lawson, 724

Morgan formation, Pennsylvanian, Utah: Richards and Mansfield, 995 .

Morgantown sandstone, Carboniferous, West Virginia: Hennen and Reger, 527; Krebs and Teets, 697.

Morrison formation, Jurassic or Cretaceous, Wyoming: Barnett 39, 41; Hewett, 534 .

Morrison shale, Jurassic or Cretaceous, Wyoming Barnett, 40.

Morrow formation, Pennsylvanian, Oklahoma Smith, 1098

Moscow shale, Devonian, New York: Houghton, 577; Luther, 775.

Mount Hope marl, Tertiary, South Carolina: Stephenson, 1129.

Mount Hope-Fairmount (Fairview), Ordovician, Indiana: Cumings and Galloway, 295 .

Mount Savage fire clay, Carboniferous, West.Virginia: Hennen and Reger, 527.

Mount Selman formation, Eocene, Texas: Deussen, 336.

Mount Simon formation, Upper Cambrian (St. Croixan), Upper Mississippi Valley: Walcott 1244.

Mount Whyte formation, Cambrian, British CoIumbia: Allan, 5, 6.

Mowry shale member, Cretaceous, Wyoming: Barnett, 39-41.

Moydart formation, Silurian, Nova Scotia: Williams, 1300

Moyie formation, pre-Cambrian, British Columbia: Schofield, 1039

Moyie sills, British Columbia: Schofield, 1042.

Moyie sills, pre-Cambrian, British Columbia: Schofield, 1042.

Muav limestone, Cambrian, Arizona: Hill, 539; Noble, 880 .

Mud Hill series, Tertiary, California: Free, 438.

Mud Lake granite, pre-Cambrian, Ontario: Lawson, 721.

Nakimu limestone, Beltian, British Columbia: Daly, 306.

Nanaimo. series, Cretaceous, British Columbia: Clapp, 223, 225; Clapp and Cooke, 230. 
Napoleon formation, Mississippian, Michigan: Smith, 1108.

Napoleon (upper Marshall) formation, Mississippian, Michigan: Cook, 273.

Narragansett series, Carboniferous, Rhode Island and Massachusetts: Warren and Powers, 1256.

Nass formation, British Columbia: McConnell, 780.

Nassau beds, Cambrian, New York: Cushing and Ruedemann, 296.

Nation River formation, Carboniferous, Alaska and Yukon: Cairnes, 186, 187, 189.

Nebraskan stage, Pleistocene, Iowa: Hay, 522.

Neva limestone, Permian, Oklahoma: Beede, 73.

Newark group, Triassic, New Jersey: Bayley et al., 66.

Newcastle formation, Cretaceous, British Columbia: Clapp, 225.

New Germantown sheet, Triassic, New Jersey: Bayley et al., 66 .

Newland ("Wallace") formation, Algonkian, Idaho and Montana: Calkins and Jones, 192.

Newman limestone, Carboniferous, Virginia: Stose, 1152.

Newman limestone, Mississippian, Kentucky: Munn, 869.

Newman limestone, Mississippian, Virginia: Butts, 179.

New Richmond sandstone, Ordovician, Illinois: Cox; 278.

New Richmond terrane, Cambrian, Iowa: Keyes, 661.

New Vernon sheet, Triassic, New Jersey: Bayley et al., 66 .

Niagara dolomite, Ordovician, Illinois: Cox, 278.

Niagara formation, Silurian, Michigan: Sherzer, 1081.

Niagara formation, Silurian, Ontario: Williams, 1303.

Niagara limestone, Silturian, Illinois: Cady, 185.

Niagara limestone, Silurian, Michigan: Smith, 1108. Niagaran series: Keyes, 661 .

Nicholas bed, Ordovician, Kentucky: Foerste, 427. Nicola group, Jura-Triassic, British Columbia: Drysdale, 369.

Nicola series, Triassic, British Columbia: Rose, 1016.

Niobrara limestones, Cretaceous, Iowa: Keyes, 655.

Niobrara shale, Cretaceous, Wyoming: Barnett, 39-41.

Niobrara terrane, Cretaceous, Iowa: Keyes, 661 .

Niobrara-Benton shales, Cretaceous, Alberta: Dowling, 362,364 .

Nipissing diabase, prè-Cambrian, Ontario: Miller and Knight, 848 .

Nipissing diabase, pre-Cambrian, Quebec: Wilson, 1313,1314 .

Nishnabotna sandstone, Cretaceous, Iowa: Keyes, 655.

Nishnabotna terrane, Cretaceous, Iowa: Keyes, 661.

Noix limestone, Silurian, Missouri: K.eyes, 659 .

Noix oolite member, Silurian, Missouri: Savage, 1031.

Nolichucky shale, Cambrian, Virginia: Stose, 1152.

Normanskill grit, Ordovician, New York: Cushing and Ruedemann, 296.

Normanskill shale, Ordovician, New York: Cushing and Ruedemann, 296.
Northbrae rhyolite, Pliocene, California: Lawson, 724 .

Northbridge gneiss, Rhode Island: Loughlin and Hechinger, 767.

Northumberland formation, Cretaceous, British Columbia: Clapp, 225.

Norton formation, Pennsylvanian, Virginia: Butts, $179,180$.

Nosoni formation, Pennsylvanian, California: Boyle, 113.

Nugget sandstone, Jurassic or Triassic, Idaho: Richards and Mansfield, 995.

Nugget sandstone, Jurassic or Triassic, Wyoming: Schultz, 1058.

Nunda sandstones, Devonian, New York: Luther, 775 .

Oakland conglomerate member, Cretaccous, California: Lawson, 724.

Octoraro mica schist, Ordovician, Pennnsylvania: Bliss and Jonas, 101.

Ohio shale, Devonian and Carboniferous, Kentucky: Morse and Foerste, 867.

Ohio shale, Devonian, Ontario: Kindle, 677 .

Ohio shales, Devonian, Ontario: Williarns, 1302.

Ojo Alamo beds, Cretaceous, New Mexico: Brown, 133.

Ojo Alamo beds, Tertiary or Cretaceous, New Mexico: Sinclair and Granger, 1093.

Okaw formation, Mississippian, Illinois: Weller, 1269.

Okaw formation, Mississippian, Mississippi Valley: Weller, 1270.

Oklahoman series: Keyes, 661 .

Olequa formation, Eocene, California and Oregon: Arnold and Hannibal, 22.

Oncida conglomerate, Devonian, New York: Clarke, 244.

Oneota dolomite, Ordovician, Illinois: Cox, 278.

Oneota dolomite, Ordovician, Minnesota: Grout and Soper, 502.

Oneota formation, Ozarkian, Upper Mississippi Valley: Walcott, 1244.

Oneota tèrrane, Cambrian, Iowa: Keyes, 661.

Onondaga limestone, Devonian, New York: Hopkin:, 571; Houghton, 577; Luther, 775.

Onondaga limestone, Devonian, Ontario: Kindle, 677.

Open Bay group, Cretaceous or Jurassic, British Columbia: Cairnes, 191.

Orange group, Mesozoic-Pennsylvanian, Alaska and Yukon: Cairnes, 187.

Orange group, Mesozoic, Yukon and Nlaska: Cairnes, 189.

Orca group, Mesozoic, Alaska: Moflit, 854 .

Oread limestone, Carboniferous, Oklahoma: Buttram, 178.

Orinda formation, Pliocene, California: Lawson, 724.

Orindan formation, Tertiary, California: Merriam, 834.

Oriskanian series: Keyes, 661 .

Oriskany, Devonian, New York: Clarke, 244.

Oriskany formation, Devonian, Maine: Pirsson and Schuchert, 955.

Oriskany sandstone, Devonian, New York: Hopkins, 571; Luther, 775. 
Oriskany sandstonc, Devonian, Ontario: Kindle, 677.

Osage group, Mississippian, Illinois: Blatchley, 100.

Osage group, Mississippian, Mississippi Valley: Weller, 1270.

Osgood limestone, Silurian, Tennessee: Drake, 366; Wade, 1239.

Otis terrane, Devonian, Iowa: Keyes, 661 .

Otter granite, Tertiary (Miocene?), British Colum bia: Camsell, 197.

Ottertail formation, Cambrian, British Columbia: Allan, 6.

Ottertail limestone formation, Cambrian, British Columbia: Allan, 5 .

Ouray limestone, Carboniferous and Devonian, Colorado: Cross and Larsen, 290.

Oursan sandstone, Miocene, California: Lawson, 724.

Ozarkian series: Keyes, 661 .

Ozarkian series, Cambrian, Lake Superior region: Keyes, 662.

Paget formation, Cambrian, British Columbia: Allan, 5,6 .

Paint Creek formation, Mississippian, Illinois: Weller, 1269.

Paint Creek formation, Mississippian, Mississippi Valley: Weller, 1270.

Palestine formation, Mississippian, Illinois: Weller, 1269.

Palestine formation, Mississippian, Mississippi Valley: Weller, 1270.

- Palisade trap, Triassic, New Jersey: Berkey and Healey, 79.

Pamelia (upper and lower), Ordovician, Ontario: Raymond, 980.

Paris formation, Ordovician, Kentucky: Foerste, 427.

Park City formation, Carboniferous, Utah: Richards and Mansfield, 995.

Park City formation, Pennsylvanian and Permian?, Wyoming: Schultz, 1058.

Parkman (?) sandstone member, Cretaceous, Wyoming: Barnett, 41.

Parkville terrane, Carboniferous, Iowa: Keyes, 661 .

Parma sandstone, Carboniferous, Michigan: Cook, 273.

Parma sandstone, Pennsylvanian, Michigan: Smith, 1108.

Parrsboro formation, Carboniferous, Nova Scotia: Hyde, 602 .

Paskapoo formation, Tertiary, Canada: Brown, 133.

Paskapoo series, Tertiary, Alberta: Dowling, 362 364

Paso Robles formation, Neocene, California: Anderson and Martin, 18.

Pawhuska limestone, Carboniferous, Oklahoma: Beede, 73.

Parnee limestone, Permian, Oklahoma: Beede, 73.

Pawtucket formation, Carboniferous, Rhode Island and Massachusetts: Warren and Powers, 1256.

Peabody granite, Mississippian or Pennsylvanian, Massachusetts: Clap, 222.

Peedee sand, Cretaceous, South Carolina: Stephenson, 1129.

Peedee sand, Upper Cretaceous, South Carolina: Berry, 80 .
Peekskill Creek limestone, New York: Fettke, 420.

Peekskill phyllite, New York: Fettke, 420.

Peerless sandstone, Carboniferous, West Virginia: Krebs and Teets, 697.

Peerless (Lower) sandstone, Carboniferous, West Virginia: Krebs and Teets, 697.

Pegram limestone, Devonian, Tennessee: Drake, 366.

Pella beds, Mississippian, Iowa: Weller, 1270.

Pella terrane, Carboniferous, Iowa: Keyes, 661 .

Pembroke formation, Silurian, Maine: Bastin and Williams, 60.

Pennington shale, Mississippian, Kentucky: Munn, 869

Pennington shale, Mississippian, Virginia: Butts, 179.

Pensauken formation, Pleistocene, New Jersey: Bayley et al., 66 .

Peoria terrane, Pleistocene, Iowa: Keyes, 661.

Peorian stage, Pleistocene, Iowa: Hay, 522.

Perry formation, Devonian, Maine: Bastin and Williams, 60.

Perryville formation, Ordovician, Kentucky: Foerste, 427; Miller, 843.

Phillips formation, pre-Cambrian, British Columbia: Schofield, 1040, 1043.

Phosphoria formation, Permian?, Montana: Stone and Bonine, 1149.

Phosphoria formation, Permian?, Idaho: Richards and Mansfield, 995.

Picton (upper and lower) formation, Ordovician, Ontario: Raymond, 980.

Pierre formation, Cretaceous, Wyoming: Barnett, 41.

Pierre shale, Cretaceous: Stanton, 1122.

Pierre shale, Cretaceous, Montana: Rogers, 1012.

Pierre shale, Cretaceous, North Dakota: Leonard, 737.

Pierre shale, Cretaceous, South Dakota: Calvert et al., 193.

Pierre shale, Cretaceous, Wyoming: Barnett, 39, 40. Pierre sha'es, Cretaceous, Canada: Brown, 133.

Pierson limestone, Mississippian, Mississippi Valley: Weiler, 1270.

Pine Creek limestone, Carboniferous, West Virginia: Hennen and Reger, 527; Krebs and Teets, 697.

Pinole tuff, Pliocene, California: Lawson, 724.

Pioche formation, Cambrian, Utah, Nevada: Burling, 157 .

Pit shales, Triassic; California: Boyle, 113.

Pitkin limestone, Mississippian, Oklahoma: Smith, 1098; Snider, 1114.

Pittsburgh (Little) limestone, Pennsylvanian, West Virginia: Krebs and Teets, 697.

Pittsburgh red shale, Carboniferous, West Virginia: Hennen and Reger, 527; Krebs and Teets, 697.

Pittsburgh sandstone, Pennsylvanian, West Virginia: Krebs and Teets, 697.

Pittsburgh (Lower) sandstone, Carboniferous, West Virginia: Hennen and Reger, 527; Krebs and Teets, 697 .

Pittsburgh (Upper) sandstone, Carboniferous, West Virginia: Hennen and Reger, 527.

Pittsford shale, Silurian, New York: Hopkins, 571 Platte terrane, Carboniferous, Iowa: Keyes, 661. 
Platteville limestone, Ordovician, Illinois: Cox, 278.

Platteville limestone, Ordovician, Minnesota: Grout and Soper, 502.

Platteville terrane, Ordovician, Iowa: Keyes, 661.

Plattsmouth terrane, Carboniferous, Iowa: Keyes, 661.

Pleasanton formation, Carboniferous, Missouri: Greene, 494.

Pochuck gneiss, pre-Cambrian, New Jersey: Bayley ct al., 66 .

Pocono series, Carboniferous, West Virginia: Hennen and Reger, 527.

Point Edward formation, Pennsylvanian, Nova Scotia: Hyde, 602.

Point Pleasant member, Ordovician, Kentucky: Foerste, 427.

Pokegama quartzite, Algonkian, Minnesota: Grout and Soper, 502.

Ponca sandstone, Cretaceous, Iowa: Keyes, 655.

Ponca terrane, Cretaceous, Iowa: Keyes, 661.

Pondville conglomerate, Permian?, Massachusetts: Loughlin and Hechinger, 767.

Pontiac schist, pre-Cambrian, Quebec: Wilson, 1313, 1314.

Pontiac series, pre-Cambrian, Quebec: Wilson, 1313. Portage beds, Devonian, New York: Houghton, 577. Port Ewen beds, Devonian, New York: Clarke, 244.

Potosi formation, Cambrian, Missouri: Lee, 727.

Potsdam sandstone, Cambrian, New York: Cushing and Ruedemann, 296.

Pottsville, Pennsylvanian, Illinois: Cady, 185.

Pottsville formation, Pennsylvanian, Illinois: Blatchley, 9s, 100; Hinds, 543.

Pottsville series, Carboniferous, West Virginia: Hennen and Reger, 527; Krebs and Teets, 697.

Poughquag quartzite, Cambrian, New York: Fottke, 420.

l'rairie du Chion series, Ordovician, Illinois: Cox, 278.

Prairie du Chien group, Ordovician, Minnesota: Grout and Soper, 502.

Price sandstone, Devonian, Virginia: Stose, 1152.

Prince Rupert formation, upper Paleozoic?, British Columbia: McConnell, 781 .

Prince Rupert schists, British Columbia: McConnell, 782.

Princeton series, pre-Cambrian, Michigan: Allen, 14; Allen and Barrett, 15.

Proctor formation, Cambrian, Missouri: Lee, 727.

Prospect Hill sheet, Triassic, New Jersey: Bayley et al., 66 .

Protection formation, Cretaceous, British Columbia: Clapp, 225.

Providence sand member, Upper Cretaceous, Georgia: Berry, 80.

Puerco formation, Tertiary, New Mexico: Brown, 133; Sinclair and Granger, 1093.

Puget formation, Tertiary, Washington: Daniels, 308.

Pulaski shale, Devonian, Virginia: Stose, 1152.

Pulaskishales, Ordovician, New York: Foerste, 428.

Purcell lava, pre-Cambrian, British Columbia: Schofield, 1040.

Purcell lava formation, pro-Cambrian, British Columbia: Schofield, 1043.
Purcell series, pro-Cambrian, British Columbia: Schofield, 1039, 1040, 1042, 1043.

Purcell sills, pro-Cambrian; British Columbia: Schofield, 1039, 1040, 1042.

Purgatory conglomerate, Permjan, Massachusetts: Loughlin and Hechinger, 767.

Put-in-Bay dolomite, Silurian, Michigan: Sherzer, 1081.

Put-in-Bay dolomite, Silurian, Ontario: Stauffer, 1123.

Puyallup clays, sands and gravels, Quatornary, British Columbia: Clapp, 225.

Puyallup interglacial deposits, Pleistocene, British Columbia: Clapp, 223, 227.

Quadrant (?) quartzite, Pennsylvanian?, Montana: Stone and Bonine, 1149.

Queen Charlotte Islands formation (?), Crotaceous, British Columbia: Drysdale, 369 .

Queen Charlotte series, Cretaceous, British Columbia: MacKenzie, 793.

Queen Charlotte series, Jurassic, British Columbia: Clapp, 227.

Queenston formation, Ordovician, New York and Ontario: Schuchert, 1054.

Queenston shales, Ordovician, Ontario: Willianns, 1303.

Queniult formation, Pliocene, Wash ington: Lupton, 774.

Quincy granite, Massachusetts: Loughlin and Hochinger, 767.

Quoddy shale, Silurian, Maine: Bastin and Williams, 60 .

Racquet group, Carboniferous, Alaska and Yukon: Cairnes, 186, 187.

Racquet series, Yukon and $\Lambda$ laska: Cairnes, 189.

Raisin River dolomite, Silurian, Michigan: Sherzer, 1081.

Raisin River dolomite, Silurian, Ontario: Stauffer, 1123.

Ralston formation, Tertiary, Wyoming: Ciranger, 485.

Ralston group, Carboniferous, Oklahoma: Beode, 73.

Ramsay Lake conglomerate, pre-Cambrian, Ontario: Coleman, 264.

Ramsay Lake series, pre-Cambrian, Ontario: Miller and Knight, 848 .

Random formation, pre-Cambrian, Nowfoundland: Van Ingen, 1222

Rapid limestone, Devonian, Iowa: Keyes, 657 .

Rapid terrane, Devonian, 'Iowa: Koyes, 661.

Raritan formation, Cretaceous, Now Jersey and Maryland: Berry, 84 .

Rattlesnake formation, Pliocene, Oregon: Collier, 266.

Ravenswood granodiorite, pro-Cambrian, New York: Berkey and Healey, 79.

Red Beds, Permian, 'Texas: Udden, 1202.

Red Head formation, Carboniferous, Quebec: Hayes, 523.

Redmond formation, Ordovician, Newfoundland: Van Ingen, 1222.

Redwall limestone, Carboniferous (Mississippian), Arizona: Noble, 880.

Redwall limestone, Carboniferous, Arizona: Hill, 539 .

$$
97921^{\circ}-\text { Bull. 617-15-11 }
$$


Renault formation, Mississippian, Illinois: Weller, 1269.

Renault formation, Mississippian, Mississippi Valley: Weller, 1270.

Rensselaer grit, Devonian, New York: Clarke, 244. Revett quartzite, Algonkian, Idaho and Montana: Calkins and Jones, 192.

Rex chert member, Permian?, Idaho: Richards and Mansfield, 995 .

Rhinestreet black shale, Devonian, New York: Luther, 775.

Rhinèstreet shale, Devonian, New York: Houghton, 577.

Rice Lake series, pre-Cambrian, Manitoba: Moore, 860.

Richmond group, Ordovician, Indiana: Cumings and Galloway, 295; Shideler, 1082.

Richmond group, Ordovician, Ontario: Williams, 1301.

Riders Brook formation, Ordovician, Newfoundland: Van Ingen, 1222

Ridgetop shale, Mississippian, Tennessee: Drake, 366; Wade, 1239.

Ripley formation, Cretaceous, Gulf States: Stephenson, 1128.

Ripley formation, Upper Cretaceous, Cieorgia: Berry, 80 .

Riverside sands, Tertiary, Iowa: Keyes, 656 .

Riverside terrane, Tertiary, Iowa: Keyes, 661 .

Roan gneiss series, pro-Cambrian, Georgia: Hopkins, 568.

Rochester member, Silurian, Ontario: Williams, 1303.

-Rochester shale, Silurian, Michigan: Smith, 1108.

Rochester shale, Silurian, New York: Schuchert, 1054.

Rockcastle conglomerate member, Pennsylvanian, Kentucky: Munn, 869.

Rockford limestone, Mississippian, Mississippi Valley: Weller, 1270.

Rockland formation, Ordovician, Ontario: Raymond, 980 .

Rockwood formation, Silurian, Virginia: Stose, 1152.

Rocky Mountain quartzite, Carboniferous, Alberta: Allan, 5.

Rodeo shale, Miocene, California: Lawson, 724.

Romney shale, Devonian, Virginia: Stose, 1152.

Rondout waterlime, Silurian, New York: Hopkins, 571 .

Ronkonkoma moraine, Quaternary, New York: Fuller, 441.

Roosville formation, pre-Cambrian, British Columbia: Schofield, 1040, 1043.

Ross quartzite, Beltian, British Columbia: Daly, 306.

Ross Brook formation, Silurian, Nova Scotia: Williams, 1300.

Roubidoux formation, Cambrian, Missouri: Lee, 727.

Rowlesburg sandstone, Devonian, West Virginia: Hennen and Reger, 527.

Roxbury conglomerate, Massachusetts: Sayles, 1034.

Roxbury conglomerate, Carboniferous, Massachusetts: Lahee, 702.

Roxbury series, Massachusetts: Sayles, 1034.
Ruffner fire clay, Pennsylvanian, West Virginia: Krehs and Teets, 697.

Ruma formation, Mississippian, Illinois: Weller, 1269.

Ruma formation, Mississippian, Mississippi Valley: Weller, 1270

Russell formation, Cambrian, Virginia: Stose, 1152.

Rustler limestone, Permian, Texas: Richardson, 999

Rysedorph Hill conglomerate, Ordovician, New York: Cushing and Ruedemann, 296.

Saanich granodiorite, British Columbia: Clapp, 227. Saanich granodiorite, Jurassic, British Columbia: Clapp, 223, 225; Clapp and Cooke, 230.

Sabula terrane, Silurian, Iowa: Keyes, 661.

Saginaw formation, Carboniferous, Michigan: Cook, 273.

Saginaw formation, Pennsylvanian, Michigan: Smith, 110s.

St. John group, Cambrian, New Brunswick: Matthew, 816 .

St. John group, Cambrian, Quebec: Hayes, 523.

St. Lawrence formation, .Cambrian, Minnesota: Grout and Soper, 502.

St. Lawrence formation, Upper Cambrian (St. Croixan), Upper Mississippi Valley: Walcott, 1244.

St. Lawrence terrane, Cambrian, Iowa: Keyes, 661.

St. Lou is formation, Mississippian, Illinois: Blatchley, 98 .

St. Lou is limestone, Mississippian, Illinois: Blatchley, 100 .

St. Louis limestone, Mississippian, Mississippi Valley: Weller, 1270.

St. Louis limestone, Mississippian, Tennessee: Drake, 366; Wade, 1239.

St. Lou is terrane, Carboniferous, Iowa: Keyes, 661.

St. Mary sills, British Columbia: Schofield, 1042.

St. Mary River formation, Upper Cretaceous or Eocene, Montana: Stebinger, 1124.

St. Marys formation, Miocene, Virginia: Olsson, 889 .

St. Peter sandstone, Ordovician; Illinois: Blatchley, 100; Cady, 185; Cox, 278.

St. Peter sandstone, Ordovician, Minnesota: Grout and Soper, 502.

St. Peter terrane, Ordovician, Iowa: Keyes, 661.

St. Peters sandstone, Ordovician, Michigan: Smith, 1108.

St. Piran formation, Cambrian, British Columbia: Allan, 5,6 .

St. Regis formation, Algonkian, Idaho and Montana: Calkins and Jones, 192.

Ste. Genevieve formation; Mississippian, Illinois: Blatchley, 98.

Ste. Genevieve limestone, Mississippian, Illinois: Blatchley, 100.

Ste. Genevieve limestone, Mississippian, Mississippi Valley: Weller, 1270.

Salem gabbro-diorite, post-Ordovician and proSilurian?, Massachusetts: Clapp, 222.

Salem limestone, Mississippian, Illinois: Blatchley, 100.

Salem limestone, Mississippian, Mississippi Valley: Weller, 1270.

Salina, Silurian, Michigan: Cook, 273.

Salina formation, Silurian, Michigan: Sherzer, 1081; Smith, 1108 
Salina limestone, Silurian, Ontario: Kindle, 677.

Salmon formation, pre-Cambrian?, Oregon: Winchell, 1320.

Salmon schist, California: Ferguson, 416.

Salmon Arm schist, pre-Beltian, British Columbia: Daly, 306.

Salmontrout limestone, Devonian, Alaska: Cairnes, 187.

Salmontrout limestone, Devonian, Alaska and Yukon: Cairnes, 186.

Saltsburgh sandstone, Carboniferous, West Virginia: Hennen and Reger, 527; Krebs and Teets, 697.

Salt Wash sandstone member, Jurassic?, Utah Lupton, 773.

Saluda, Ordovician, Indiana: Cumings and Galloway, 295 .

Saluda beds, Ordovician, Indiana: Shideler, 1082.

Salvisa limestone, Ordovician, Kentucky: Foerste, 427.

Salvisa member, Ordovician, Kentucky: Miller, S43.

San Antonio formation, Pleistocene, California: Lawson, 724.

Sand Coulee beds, Tertiary, Wyoming: Granger, 485.

Sangamon stage, Pleistocene, Iowa: $\mathrm{H}$ Tay, 522.

San Pablo formation, Miocene, California: Lawson, 724.

San Pedro formation, Quaternary, California: Ar: nold, and Garfias, 21.

Santa Clara formation, Pliocene and Quaternary, California: Lawson, 724

Santa Margarita(?) formation, Miocene, California: 'Pack and English, 903.

Santa Margarita group, Neocene, California: Anderson and Martin, 18.

Satanka (?) shale, Carboniferous, Wyoming: Barnett, 41 .

Saugus granodiorite, post-Ordovician and pre-Silurian?, Massachusetts: Clapp, 222.

Saugus quartz diorite, post-Ordovician and preSilurian?, Massachusetts: Clapp, 222.

Sausalito chert, Jurassic?, California: Lawson, 724. Savanna formation, Pennsylvanian, Arkansas and Oklahoma: 'Smith, 1097.

Savanna formation, Pennsylvanian, Oklahoma: Snider, 1113

Saverton terrane, Carboniferous, Iowa: Keyes, 661. Sawback formation, Devonian, Alberta: Allan, 5 .

Schaghticoke shale, Ordovician, New York: Cushing and Ruedemann, 296.

Schenectady formation, Ordovician, New York: Cushing and Ruedemann, 296.

Schodack shales and limestones, Cambrian, New York: Cushing and Ruedemann, 296.

Seaforth limestone, Oligocene?, Antigua: Brown, 130.

Seine conglomerate, pre-Cambrian, Ontario: Lawson, 721.

Seine series, pre-Cambrian, Ontario: Lawson, 721; Miller and Knight, 848 .

Selkirk series, Beltian, British Columbia: Daly, 306. Selkirk series, pre-Cambrian, British Columbia: Schofield, 1041.

Selkirkic period, pre-Cambrian, Lake Superior region: Keyes, 662 .
Selma chalk, Cretaceous, Gulf States: Stephenson, 1128.

Senecan series: Keyes, 661

Sergeant shales, Cretaceous, Iowa: Keyes, 655.

Sergeant terrane, Cretaceous, Iowa: Keyes, 661.

Sespe formation, Oligocene, California: Arnold and Garfias, 21.

Sevier shale, Ordovician, Virginia: Stose, 1152.

Sewickley sandstone, Pennsylvanian, WestVirginia: Krebs and Teets, 697.

Sexton Creek limestone, Silurian, Tllinois: Savage, 1031.

Shakopee dolomite, Ordovician, Illinois: Cady, 185; Cox, 278 .

Shakopee dolomite, Ordovician, Minnesota: Grout and Soper, 502.

Shakopee formation, Canadian, Upper Mississippi Valley: Walcott, 1244.

Shakopec terrane, Cambrian, Iowa: Keyes, 661.

Shannon(?) sandstone lentil, Cretaceous, Wyoming: Barnett, 41 .

Sharon conglomerate, Carboniferous, West Virginia: Hennen and Reger, 527.

Shasta series, Cretaceous, California: Pack and English, 903.

Shawangunk conglomerate, New York: Brown, 140.

Shawangunk grit, Devonian, New York: Clarke, 244.

Shenandoah limestone, Cambro-Ordovician, J'ennsylvania: Bliss and Jonas, 101.

Sherbrooke formation, Cambrian, British Columbia: Allan, 5,6

Shinarump conglomerate, Triassic, Arizona: Greg॰ ory, 497 .

Shinumo quartzite, Algonkian, Arizona: Noble, 880.

Shulie formation, Pennsylvanian, Nova Scotia: Bell, 77 .

Shuswap series, British Columbia: Schofield, 1041. Shuswap series, pre-Beltian, British Columbia: Daly, 306.

Shuswap terrane, pre-Beltian, British Columbia: Daly, 306.

Sicamous limestone, pre-Beltian, British Columbia: Daly, 306.

Sicker schists, Jurassic or Triassic, British Columbin: Clapp, 223.

Sicker series, Jurassic or Triassic, British Columbia: Clapp, 223, 225.

Sicker series, Jurassic?, British Columbia: Clapp and Cooke, 230.

Sicker volcanics, Jurassic or Triassic, British Columbia: Clapp, 223.

Siesta formation, Pliocene, California: Jawson, 724 Siestan formation, Tertiary, California: Merriam, 834.

Signal Hill formation, pre-Cambrian, Newfoundland: Van Ingen, 1222.

Sillery formation, Cambrian, Quebec: Dresser, 367.

Sir Donald formation, Cambrian, British Columbia: Daly, 306.

Sioux terrane, pre-Cambrian, Iowa: Keyes, 661 .

Siyeh formation, pre-Cambrian, British Columbia: Scohfield, 1040, 1043.

Siyeh limestone, pre-Cambrian, British Columbia: Walcott, 1246. 
Skaneateles shale, Devonian, New York: Houghton, 577; Luther, 775.

Skeena formation, Cretaceous, British Columbia: McConnell, 781.

Skeena series, Cretaceous or Jurassic?, British Columbia: Malloch, 802 .

Skidegate formation, Cretaceous, British Columbia: MacKenzie, 793.

Skidegate member, Jurassic, British Columbia: Clapp, 227.

Smithfield limestone, pre-Cambrian, Rhode Island and Massachasetts: Warren and Powers, 1256.

Smith Point formation, Cambrian, Newfoundland: Van Ingen, 1222.

Snake Hill formation, Ordovician, New York: Cushing and Ruedemann, 296.

Sobrante sandstone, Miocene, California: Lawson, 724.

Sodus member, Silurian, Ontario: Williams, 1303.

Sodus shale, Silurian, New York: Schuchert, 1054.

Solen limestone, Devonian, Iowa: Keyes, 657.

Solon terrane, Devonian, Iowa: Keyes, 661.

Somerville slates, Carboniferous, Massachusetts: Lahee, 702.

Sooke formation, Miocene, British Columbia: Clapp, 227.

Sooke gabbro, Oligocene, British Columbia: Cooke, 276.

Sooke intrusives, post-Eocene, British Columbia: Clapp, 227.

Soudan formation, Archean, Minnesota: Grout and Soper, 502.

Soultan series, pre-Cambrian, Lake Superior region: Keyes, 662.

Southgate, Ordovician, Indiana: Cumings and Galloway, 295.

Spann limestone member, Mississippian, Kentucky: Munn, 869.

Spence Bridge volcanic group, Jura-Cretaceous, British Columbia: Drysdale, 369 .

Spergen terrane, Carboniferous, Iowa: Keyes, 661.

Split-rock terrane, pre-Cambrian, Iowa: Keyes, 661.

Sprout Brook limestone, New York: Fettke, 420.

Squantum slates, Carboniferous, Massachusetts: Lahee, 704.

Squantum tillite, Carboniferous, Massachusetts: Lahee, 702; Sayles, 1034.

Stafford limestone, Devonian, New York: Hough, ton, 577.; Luther, 775.

Stanton terrane, Carboniferous, Iowa: Keyes, 661.

Star Peak formation, Triassic, Nevada: Schrader, 1048.

Staten Island serpentine, pre-Cambrian, New York: Berkey and Healey, 79.

Steep Rock series, pre-Cambrian, Ontario: Miller and Knight, 848.

Stephen formation, Cambrian, British Columbia: Allan, 5, 6 .

Sterling granite-gneiss, Rhode Island: Loughlin. and Hechinger, 767.

Stillwater formation, Tertiary, Alaska: Fisher and Calvert, 422.

Stockbridge dolomite, Cambrian and Ordovician, New York: Fuller, 441.

Stockton formation, Triassic, New Jersey: Bayley et al., 66 .
Stockton shales, Carboniferous, West Virginia: Krebs and Teets; 697.

Stonehouse formation; Silurian, Nova Scotia: Williams, 1300.

Stonewall limestone, Silurian, Manitoba: Kindle, 676.

Stonewall series, Silurian, Manitoba: MacLean and Wallace, 796.

Stony Mountain group, Ordovician, Manitoba: MacLean and Wallace, 796.

Striped Peak formation, Algonkian, Idaho and Montana: Calkins and Jones, 192.

Sudbury series, pre-Cambrian, Canada: Coleman, 262.

Sudbury series, pre-Cambrian, Ontario: Coleman, 264; Collins, 269; Miller and Knight, 848.

Sunbury shale, Carboniferous, Ohio and Kentucky: Morse and Foerste, 867.

Sundance formation, Jurassic, Wyoming: Barnett, 39, .41; Hewett, 534 .

Supai formation, Carboniferous, Arizona: Noble, 880.

Supai formation, Carboniferous (Pennsylvanian), Arizona: Hill, 539.

Superioric period, pre-Cambrian, Lake Superior region: Keyes, 662 .

Sutton formation, Jurassic, British Columbia: Clapp, 223.

Sutton limestones, Jurassic and Triassic?, British Columbia: Clapp, 227; Clapp and Cooke, 230.

Sweetland Creek shale, Devonian, Illinois: Cady, 185.

Sylvania formation, Silurian, Michigan: Sherzer, 1081 ; Smith, 1108.

Sylvania sandstone, Silurian, Ontario: Stauffer, 1123.

Tapeats sandstone, Cambrian, Arizona: Hill, 538; Noble, 880.

Teapot sandstone member, Cretaceous, Wyoming: Barnett, 39.

Tejon, Eocene, California and Oregon: Arnold and Hannibal, 22 .

Tejon, Tertiary, California: Dickerson, 340 .

Tejon formation, Eocene, California: $\Lambda$ rnold and Garfias, 21; Lawson, 724; Waring, 1254.

Tejon formation, Tertiary, California: Pack and English, 903.

Tejon group, Eocene, California: Dickerson, 341.

Tejon group, Tertiary (Eocene), California: Dickerson, 339.

Temblor group, Neocene, California: Anderson and Martin, 18.

Temescal formation, Recent, California: Lawson, 724.

Temiskamian, pre-Cambrian, Ontario: Miller and Knight, 848.

Temiskaming series, pre-Cambrian, Ontario: Miller and Knight, 848.

Temiskaming. Sce also Timiskaming.

Temple Bar conglomerate, Quaternary, Arizona: Blanchard, 96.

Tennessean series: Keyes, 661 .

Texada formation, Jurassic?, British Columbia: MeConnell, 782.

Thayer terrane, Carboniferous, Iowa: Keyes, 661 . Thaynes limestone, Triassic, Idaho: Richards and Mansfield, 995. 
Thaynes limestone, Triassic, Wyoming: Schultz, 1058.

Theresa formation, Cambrian, New York: Cushing and Ruedemann, 296.

Thomaston granite, New York: Fettke, 420.

Thorold member, Silurian, New York and Ontario: Schuchert, 1054.

Thorold member, Silurian, Ontario: Williams, 1303.

Tice shale, Miocene, California: Lawson, 724.

Tichenor limestone, Devonian, New York: Froughton, 577; Luther, 775.

Timiskaming series, pre-Cambrian, Ontario: Burrows and Hopkins, 164.

Timiskaming series, pre-Cambrian, Canada: Coleman, 262.

Timiskaming series, pre-Cambrian, Quebec: Coleman, 264.

Tindir group, Cambrian, Alaska and Yukon: Caimes, 186.

Tindir group, Cambrian or pre-Cambrian, Alaska and Yukon; Cairnes, 187.

Tindir group, pre-Cambrian?, Yukon and Alaska: Cairnes, 189.

Tipton terrane, pre-Cambrian, Iowa: Keyes, 661.

Tokun formation, Tertiary, Alaska: Fisher and Calvert, 422 .

Tombigbee sand member, Cretaceous, Gulf States: Stephenson, 112s.

Tombigbee sand member, Upper Cretaceous, Georgia: Berry, 80.

Tonkawatla formation, pre-Beltian, British $\mathrm{C}_{0}$ lumbia: Daly, 306

Tonto group, Cambrian, Arizona: Hill, 539; Noble, 880.

Torrejon formation, Tertiary, New Mexico: Sinclair and Granger, 1093.

Tranquille beds, Tertiary, British Columbia: Rose, 1016 .

Traverse formation, Devonian, Michigan: Smith, 1108.

Traverse group, Devonian, Michigan: Cook, 273; Sherzer, 1081.

Trenton formation, Ordovician, Illinois: Cady, 185.

Trenton group, Ordovician, Quebec and Ontario: Raymond, 980.

Trenton limestone, Ordovician, Michigan: Smith, 1108.

Trenton limestone, Ordovician, Ontario: Johnston, 626.

Tribune formation, Mississippian, Illinois: Blatchley, 98.

Trinity group, Cretaceous, Texas: Richardson, 999.

Trout Lake conglomerate, pre-Cambrian, Ontario: Coleman, 264.

Troy shales, Cambrian, New York: Cushing and Ruedemann, 296.

Tshinakin formation, pre-Beltian, British Columbia: Daly, 306 .

Tulameen group, Triassic?, British Columbia: Camsell, 197.

Tulare formation, Pliocene, California: Pack and English, 903.

Tullahoma group, Mississippian, Tennessee: Wade, 1239.

Tully horizon, Devonian, New York: Houghton, 577; Luther, 775.

Tully terrane, Devonian, Iowa: Keyes, 661 .
Turtle Mountain group, Devonian and Carboniferous, Alberta: Mackenzic, 794.

Tuscaloosa formation, Cretaceous, Gulf States: Stephenson, 1128.

Tuscaloosa formation, Cretaceous, Tennessee: Drake, 366 .

Twin Creek limestone, Jurassic, Idaho: Richards and Mansfield, 995.

Twin Creek limestone, Jurassic, Wyoming: Schulti, 1058.

Two Medicine formation, Cretaceous, Montana: Stebinger, 1125, 1126.

T'wo Mile limestones (Ames limestone), Pennsylvanian, West Virginia: Krels and 'T'eets, 697.

Tyee porphyrite, Jurassic, British Columbia: Clapp and Cooke, 230

Tyee sandstone, Eocene, Oregon: Washburne, 1257.

Tymochtee shales, Silurian, Michigan: Sherzer, 1081.

Tymochtee shales, Silurian, Ontario: Stauffer, 1123. Uffington shale, Carboniferous, West Virginia: Hennen and Reger, 527.

Uinta formation, Tertiary, Utah: Douglass, 360 .

Umpqua formation, Eocene, Oregon: Washburne, 1257.

Umpqua formation, l'ertiary, Oregon: Dickerson, 347.

Uncompahgre formation, Algonkian, Colorado: Cross and Larsen, 290.

Uniontown sandstone, Pennsylvania, West Virginia: Krebs and T'eets, 697 .

Unkar group, Algonkian, Arizona: Noble, 880.

Utica formation, Ordovician, Quebec and Ontario: Raymond, 980

Utica shale (Eden), Ordovician, Michigan: Smith, 1108.

Uvalde formation, Pliocene, T'exas: Deussen, 336.

Valdes formation, Cretaceous or Jurassic, British Columbia: Cairnes, 191.

Valdez group, Mesozoic?, Alaska: Moffit, 854

Vancouver group, Jurassic and Triassic?, British Columbia: Clapp, 223, 225, 226, 227; Clapp and Cooke, 230 .

Vancouver group, Jurassic and Triassic?, British Columbia: MacKenzie, 793

Vancouver volcanics, British Columbia: Clapp, 223.

Vancouver volcanics, Jurassic or Triassic, British Columbia: Clapp, 225, 227.

Vancouver volcanics, Jurassic and Triassic?, British Columbia: Clapp and Cooke, 230.

Van Horn sandstone, Cambrian?, Texas: Riehardson, 999

Vanport limestone, Carboniferous, West Virginia: Fennen and Reger, 527 .

Vaqueros formation, Miocene, California: Dickerson, 341; Pack and Enylish, 903.

Varennesic period, pre-Cambrian, Lake Superior region: Keyes, 662.

Vashon drift, Pleistocene, British Columbia: Clapp, 223,227 .

Vashon drift, Quaternary, British Columbia: Clapp, 225.

Verdi terrane, Carboniferous, Iowa: Keyes, 661.

Vermont formation, Cambrian, Vermont: Gordon, 476 . 
Vernon red shale, Silurian, New York: Hopkins, 571.

Versailles beds, Ordovician, Indiana: Shideler, 1082.

Vineyard formation, Quaternary, New York: Fuller, 441.

Virgelle sandstone, Cretaceous, Montana: Stebinger, 1125, 1126.

Virginia slates, Algonkian, Minnesota: Grout and Soper, 502.

Vishnu schist, Archean, Arizona: Noble, 880.

Wabana series, Ordovician, Newfoundland: Van Ingen, 1222.

Wabash stage, Pleistocene, Iowa: Hay, 522 .

Waccamaw marl, Miocene, South Carolina: Rogers, 1013.

Waconia moraine, Pleistocene, North Dakota: Simpson, 1090.

Waits River limestone, Ordovician, Vermont: Dale, 300; Richardson and Turner, 996; Richardson et al., 997.

Waldron clay, Silurian, Tennessee: Drake, 366; Wade, 1239.

Wall Creek(?) sandstone lentil, Cretaceous, Wyoming: Barnett, 41.

Wall Creek sandstone member, Cretaceous, Wyoming: Barnett, 39 .

Wamsutta beds, Carboniferous, Rhode Island and Massachusetts: Warren and Powers, 1256.

Wamsutta formation, Permian?, Massachusetts Loughlin and Eechinger, 767 .

Wanapitei quartzite, pre-Cambrian, Ontario: Colo man; 264.

Wanipigow series, pre-Cambrian, Manitoba: Moore, 860.

Wanipigow series, pre-Cambrian, Ontario: Miller and Knight, 848 .

Wappinger limestone, Cambrian and Ordovician, New York: Fettke, 420.

Wardner formation, Mississippian, British Columbia: Schofield, 1040, 1041.

Wardner limestone, Mississippian, British Columbia: Schofield, 1039.

Wark gneiss, British Columbia: Clapp, 227.

Wark gneiss, Jurassic, British Columbia: Clapp, 223; Clapp and Cooke, 230.

Warsaw formation, Mississippian, Mssissippi Valley: Weller, 1270.

Warsaw terrane, Carboniferous, Iowa: Keyes, 661.

Wasatch beds, Tertiary, Wyoming: Granger, 485.

Wasatch formation, Tertiary, Colorado and Utah: Woodruff and Day, 1333.

Wasatch group, Tertiary, Wyoming: Schultz, 1058 . Washington fireclay shales, Permo-Carboniferous, West Virginia: Krebs and Teets, 697.

Washita group, Cretaceous, Texas: Richardson, 999.

Watchung basalt, Triasssic, New Jersey: Bayley et al., (66.

Waucoma limestone, Silurian, Illinois and Iowa: Savage, 1031.

Waverly formation, Mississippian, Kentucky: Munn, 869.

Waverly series or Waverlian series, Carboniferous, Ohio and Kentucky: Morse and Foerste, 867.

Waverlyan series: Keyes, 661.
Wayne formation, Silurian, Tennessee: Drake 366; Wade, 1239.

Waynesburg sandstone, Permo-Carboniferous, West Virginia: Krebs and Teets, 697.

Waynesville, Ordovician, Indiana: Cumings and Galloway, 295.

Weber quartzite, Pennsylvanian, Wyoming: Schultz, 1058.

Wells formation, Pennsylvanian, Idaho: Richards and Mansfield, 995.

Westerville limestone, Pennsylvanian, Iowa: Tilton, 1170.

West River shale, Devonian, New York: Houghton, 577; Luther, 775 .

West Union bed, Silurian, Ohio: Morse and Foerste, 867.

Weymouth formation, Cambrian, Massachusetts: Loughlin and Hechinger, 767.

Whirlpool sandstone member, Silurian, New York and Ontario: Schuchert, 1054.

Whirlpool member, Silurian, Ontario: Williams, 1303.

White River formation, Tertiary, North Dakota: Lloyd, 758.

White River formation, Tertiary, Wyoming: Barnett, 39,41 .

Wichita formation, Carboniferous, Texas: Case, 208.

Wichita formation, Permian, Oklahoma: Munn, 869.

Wilcox formation, Eocene, Texas: Deussen, 336.

Wilkeson formation, Tertiary, Washington: Daniels, 308 .

Williamson member, Silurian, Ontario: Williams, 1303.

Williamson shale, Silurian, New York: Schuchert, 1054.

Willow Creek formation, Upper Cretaceous or Eocene, Montana: Stebinger, 1124.

Wilmore formation, Ordovician, Kentucky: Miller, 843.

Wilmore member, Ordovician, Kentucky: Foerste, 427.

Wilson formation, Carboniferous, Oklahoma: Buttram, 178.

Windsor formation, Mississippian, Nova Scotia: Bell, 77.

Windsor series, Carboniferous, Nova Scotia: Hyde, 602.

Windsor series, Mississippian, Nova Scotia: Hyde, 602.

Winifrede (Lower) sandstone, Carboniferous, West Virginia: Krebs and Teets, 697.

Winilrede (Upper) sandstone, Carboniferous, West Virginia: Krebs and Teets, 697.

Winnipegosan dolomite, Devonian, Manitoba: Kindle, 67c; MacLean and Wallace, 796.

Winslow formation, Pennsylvanian, Oklahoma: Snider, 1113.

Winston limestone, Silurian, Illinois, Iowa: Savage, 1031.

Winterset limestone, Pennsylvanian, Iowa: Tilton, 1070 .

Wisconsin drift, Pleistocene, New Jersey: Bayley et al., 66 .

Wisconsin drift, Quaternary, New York: Fuller, 441. 
Wisconsin stage, Pleistocene, Towa: Hay, 522.

Wisconsin stage, Pleistocene, Maine: Bastin and Williams, 60.

Wisconsin terrane, Pleistocene, Iowa: Keyes, 661. Wiscoy shale, Devonian, New York: Houghton, 577.

Wiscoy shales, Devonian, New York: Luther, 775. Wise formation, Pennsylvanian, Virginia: Butts, $179,180$.

Wissahickon mica gneiss, pro-Cambrian, Pennsylvania: Bliss and Jonas, 101.

Wolcott limestonẹ, Silurian, New York: Schuchert, 1054.

Wolcott member, Silurian, Ontario: Williams, 1303.

Woodburn, Ordovician, Kentucky: Miller, 843 .

Woodbury shales, Cretaceous, Iowa: Keyes, 655 .

Woodbury terrane, Cretaceous, Iowa: Keyes, 661.

Woodside shale, Triassic, Idaho: Richards and Mansfield, 995.

Woodside formation, Triassic, Wyoming: Schuitz, 1058.
Woodville sandstone, Permo-Carboniferons?, Michigan: Smith, 1108.

Yakoun volcanics, Jurassic, British Columbia: MacKenzie, 793.

Yankeetown. formation, Mississippian, Illinois: Weller, 1269.

Yankeetown formation, Mississippian, Mississippi Valley: Weller, 1270.

Yarmouth stage, Pleistocene, Iowa: Hay, 522.

Yegua formation, Eocene, Texas: Deussen, 336.

Yonkers gneiss, pre-Cambrian, New York: Berkey and Fealey, 79.

Yorktown formation, Miocene, Virginia: Olsson, 889.

Yukon group, pre-Cambrian, Alaska and Yukon: Cairnes, 186, 189.

Yukon group, pre-Cambrian?, Yukon and Alaska: Cairnes, 187.

Zion Hill quartzite, Cambrian, New York: Cushing and Ruedemann, 296.

Zuni sandstone, Cretaceous, New Mexico: Winchester, 1324. 